UNIVERSIDADE DE SÃO PAULO

FACULDADE DE FILOSOFIA, LETRAS E CIÊNCIAS HUMANAS

DEPARTAMENTO DE LETRAS CLÁSSICAS E VERNÁCULAS

PROGRAMA DE PÓS-GRADUAÇÃO EM LITERATURA BRASILEIRA

Do Futuro e da Morte do Teatro Brasileiro:

Uma Viagem pelas Revistas Literárias e Culturais do Período

Modernista (1922 - 1942)

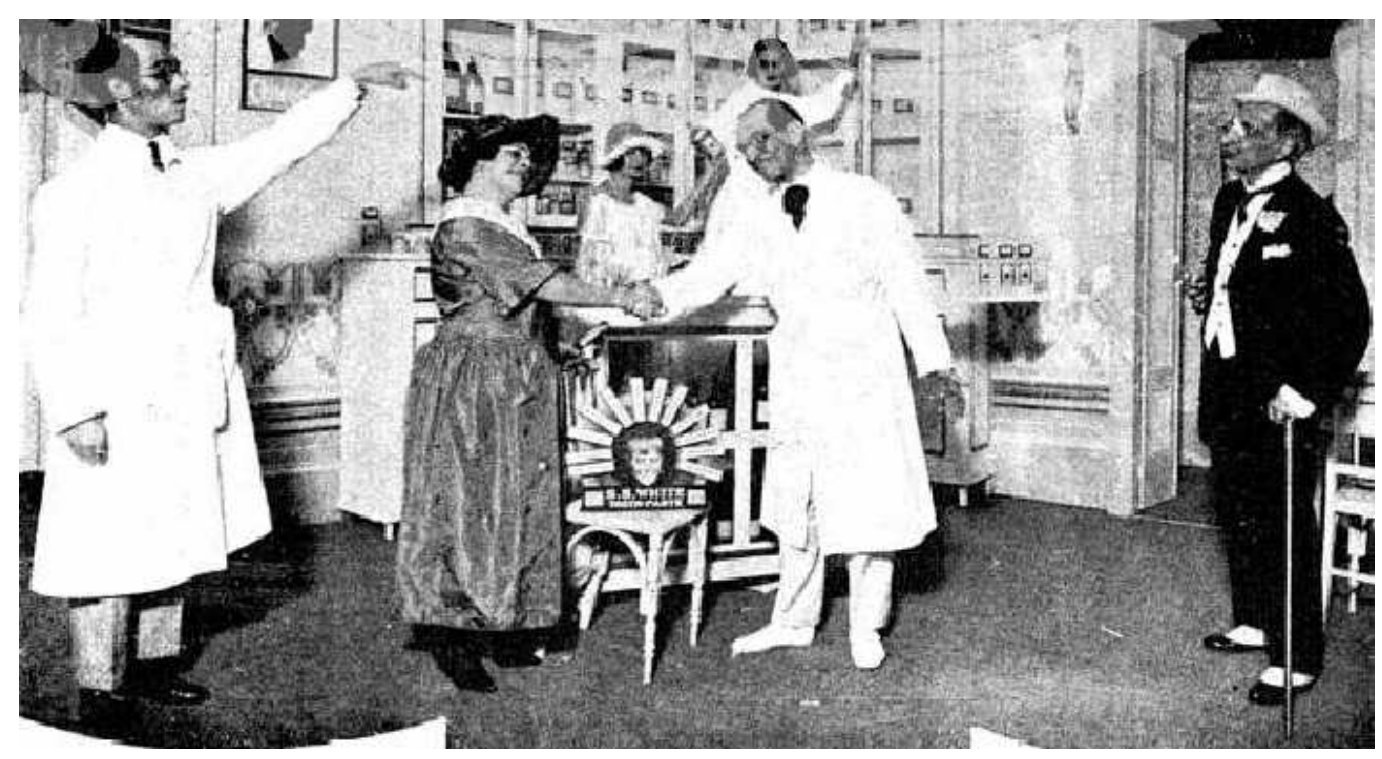

Christina Barros Riego

São Paulo

2008

Volume I 
UNIVERSIDADE DE SÃO PAULO

FACULDADE DE FILOSOFIA, LETRAS E CIÊNCIAS HUMANAS

DEPARTAMENTO DE LETRAS CLÁSSICAS E VERNÁCULAS

PROGRAMA DE PÓS-GRADUAÇÃO EM LITERATURA BRASILEIRA

\title{
Do Futuro e da Morte do Teatro Brasileiro: \\ Uma Viagem pelas Revistas Literárias e Culturais do Período \\ Modernista (1922 - 1942)
}

\section{Christina Barros Riego}

\begin{abstract}
Dissertação apresentada ao Programa de PósGraduação em Literatura Brasileira, do Departamento de Letras Clássicas e Vernáculas da Faculdade de Filosofia, Letras e Ciências Humanas da Universidade de São Paulo, para a obtenção do título de Mestre em Letras.
\end{abstract}

Orientador: Prof. Dr. João Roberto Gomes de Faria

São Paulo

2008

Volume I 
Para os incansáveis guardiões dos meus sonhos: meus pais - João e Terezinha.

"O amor só é lindo, quando encontramos alguém que nos transforme no melhor que podemos ser".

(Mário Quintana) 


\section{Agradecimentos}

O teatro - arte da coletividade - só é idealizado e concretizado através de um sonho comum compartilhado por vários corações. A união de diferentes razões, talentos e sentimentos garante a produção cuidadosa e apaixonada de cada momento do espetáculo. Os aplausos finais geralmente destinam-se ao momento presente levado à cena, e não ao árduo trabalho de planejamento e aos insistentes ensaios que resultam na composição final. Assim como um espetáculo, nossas conquistas são sempre coletivas na medida em que contamos e precisamos de ajuda e apoio de várias pessoas ao longo do caminho. É por isso que agradeço:

Em primeiro lugar, aos meus pais pelo exemplo de coragem e determinação. Ao meu pai - João - por acreditar em meus sonhos antes mesmo do que eu, pela certeza incondicional do meu sucesso e por me garantir todas as ferramentas e materiais necessários para minha formação. À minha mãe - Terezinha - por admirar sinceramente a minha profissão, por respeitar minhas escolhas, pelo carinho e estímulo nas horas de cansaço e por encontrar todos os textos que eu perdia nos amontoados de papéis espalhados pela casa.

Ao meu irmão Henrique por todo incentivo e interesse, mas acima de tudo, por todo auxílio técnico dispensado ao longo dos últimos anos e pela certeza reconfortante de que ele sempre estará por perto.

Ao Renato, que voltou a fazer parte desse sonho e da minha vida, agradeço pelo companheirismo e paciência. Uma pessoa especial que abriu mão de momentos de descanso para estar ao meu lado, dispensando finais de semanas e, até mesmo férias, para me acompanhar.

À minha família, que soube entender minhas ausências e minhas razões. Mesmo distante, suas orações fortaleceram meu trabalho e me fizeram chegar até aqui. 
Aos meus amigos, que, direta ou indiretamente, contribuíram com esta pesquisa e torceram por mim. À Renata, pela companhia nas tardes na biblioteca do IEB, e ao Eduardo, por abrir caminhos e acalmar minha alma.

Ao Prof. Dr. João Roberto Faria, cujas indicações despertaram em mim um interesse ainda maior pelo estudo do teatro brasileiro e o gosto pela pesquisa em fontes primárias. Destaco a orientação séria e presente que me acompanha desde os tempos de Iniciação Científica. Pelo apoio e atenção, pela paciência e confiança, deixo aqui registrado o meu sincero agradecimento.

E aos membros de minha banca de qualificação, Profa Dra. Orna Messer Levin e Prof. Dr. Marcos Antonio de Moares, pelos comentários e contribuições que ampliaram caminhos e renovaram meu olhar cansado.

Assim, encerra-se [ou se inicia] mais um espetáculo em minha vida! 
Resumo: Este trabalho tem como principal objetivo apresentar os dados encontrados no levantamento feito em revistas literárias e culturais do período que vai de 1922-1942, para conhecer as principais preocupações e contribuições dos escritores e intelectuais para o processo de modernização do teatro brasileiro. O primeiro volume contempla um estudo interpretativo, de cunho histórico e crítico, que abrange desde as características do teatro em voga na época até as tentativas de modernização e a concorrência com o cinema e o rádioteatro. O segundo volume deste trabalho apresenta o índice classificatório das matérias, elaborado a partir dos dados coletados durante a pesquisa, que permite uma fácil localização de boa parte do que foi publicado sobre o teatro na época.

Palavras-Chave: Teatro brasileiro, revistas literárias e culturais, Modernismo, cinema, rádio-teatro.

\begin{abstract}
The main purpose of this dissertation is to present the data found and collected from some cultural and literary magazines during the period of 1922-1942, in order to understand the main concerns and contributions of writers and intellectuals in the modernization process of the Brazilian theater. The first volume brings a historical and critical interpretative study that not only points out the main characteristics of the theatrical productions of that period, but also its modernization initiatives and its competition with the cinema and the radio-theater. The second volume of this dissertation presents the classificatory index of the collected data, elaborated along with the research to provide a feasible tool for locating this material.
\end{abstract}

Key Words: Brazilian theater, literary and cultural magazines, Modernism, cinema, radiotheater. 


\section{Índice}

\section{VOLUME I}

Introdução

1. Revistas, Boletins e Anuários: Os Periódicos Analisados........................................32

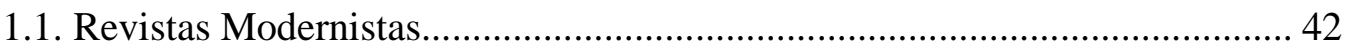

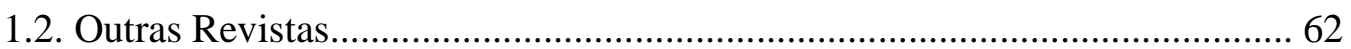

2. O que se Promete... Companhias, Atores e Dramaturgos em Destaque.................. 92

2.1. A Arte de Fazer Rir: os Dramaturgos em Foco............................................... 94

2.2. Os Mágicos da Cena: as Companhias e seus Astros.......................................118

3. Do Futuro e da Morte do Teatro Brasileiro............................................................ 135

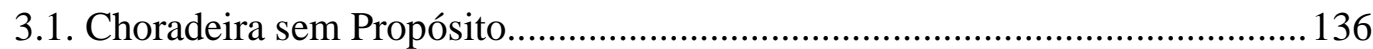

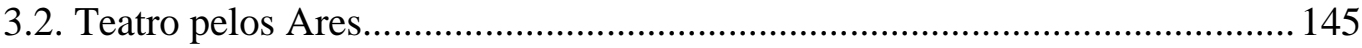

4. O Processo de Afirmação da Cena Moderna Brasileira........................................... 162

4.1. O Teatro da Década de 20 e o Projeto Estético do Modernismo..................... 167

4.2. Projeto Ideológico do Teatro Nacional: o Caminho da Modernização.......... 184

4.3. Os Intelectuais e o S.N.T.: Um Parêntesis Final................................................195

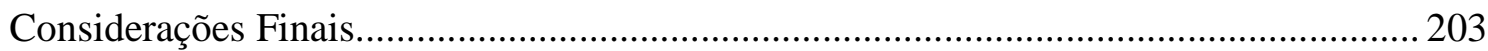

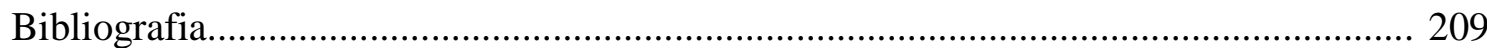

\section{VOLUME II}

Índice Classificatório

Anexos 


\section{Antinous}

(fragmento)

Episodio quasi dramatico

ortejo. Desfile de automoveis. Gritos. Charivari. Bumbum dos tambores. Escravos de todas as cores curvados como canivetes. Espadas em branco que desfilam intermittentes e interminaveis...

$$
\text { A voz do orador }
$$

... o Sabio... o Const́rurtor. 0 Imperador constructor por excellencia. Aquelle que soube submetter toda a natureza ás suas ordens e ás suas leis. 0 Haussman, o Bumham, o Passos romanol 0 Sabio, o Constructor....

$$
\text { A multidão }
$$

Muito bem. Bravos. Apoiado. Apoiadissí....

$$
\text { A voz do orador }
$$

0 constructor, o reconstruc. tor, o guerreiro, o vencedor, o... A voz do outro orador (ao mesmo tempo)
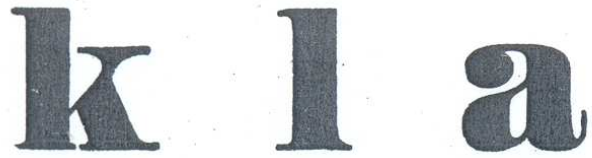
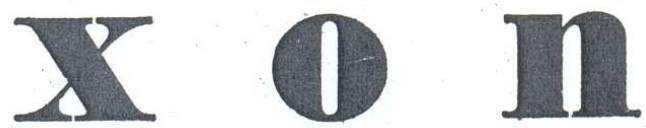

Sim senhores, o Imperador architecto. 0 Imperador artista. Vêde esta cidade monstro com seus edificios, seus arranhacéus, com suas ruạs asphaltadas, com seus annuncios, com seus cinemas, seus cartazes... Vêde este palacio... (Aponta para um palacio que tem o aspecto de um formidavel queijo de Minas). Vêde a civilisação borborinhante que enche as nossas ruas, as nossas praças, os nossos boulevards, os nossos... Vêde tudo o que nos cerca. Tudo, tudo obra de um só homem. De um só cerebro.

Continua o cortejo. Duas fileiras de escravos, dobrados como canivetes estendem-se desde a porta principal do palacio até o Infinito. Por entre ellas passam automoveis de todos os feitios. Dois homens de preto conversam afastados da multidão.

Trecho da peça Antinous, de Sérgio Buarque de Hollanda.

Fonte: Klaxon: mensário de Arte Moderna. SP, n. 04, ago/1922, p.01. 


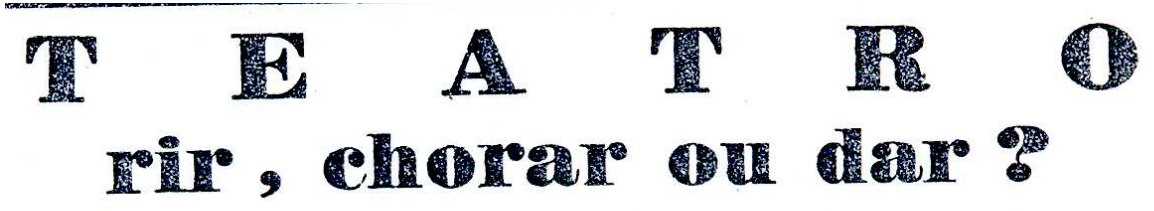

Em matéria de teatro sampre me/cima pobre. Com certaza. Nem toaparece cada idéa no Brasil! Meu Deus do céu!

Ontem era Cludio de Souza que queria realizar uma temporada naclonal em Paris. Vejam s6. Agora é não sei quem quo funda uma Academia Teatral. Imaginem $\$ 6$.

Onde é que vamos parar assim?

Arrepia só de pensar.

Pois então já não é suflciente a Academia de Letras para escangalhar com a vida literária da gen. te? Que diabo!

Vamos falar sério. O teatro bra. sileiro é um pobre desgraçado. Nao tem por onde se lhe agarre. Para que lhe aumentar a miséria com um grupo de imortais. Para que?

$$
\text { * * }
$$

Ora para que! Para vaidade de seus fundadores. Está claro. ISão cavalheiros que morrem por uma imortalidade acadêmica. E depois a gloria! Ah a gloria!

E. Isso mesmo. O teatro brasileiro não tem nada. Nada de nada. Não tem peças. Não tem intérpretes. Em troca terá acadêmicos. Esses acadêmicos por sua vez tambêm năo têm nada. Nada de nada. Pois terão fardas.

Al está.

Fiquei assombrado ao ler na lista dos quarenta fundadores os nomes de sete ou oito pessoas que eu prezo já não digo pelo seu talento (que têm) mas pelo seu bom senso.

Que muitas que lá figuram não possuem a mínima noção do ridiculo eu sabia ou presumia. Mas as tais sete ou oito não têm desculpa. S6 se não foram cheiradas nem ouvidas. Mas se assim é estão na obrigacão de fugirem publicamente de semelhante bobagem. Quanto mais depressa melhor. Antes que fiquem desmoralizadas.

* * *

Porque afinal de contas no que consiste e o que fará a Academia Teatral do Brasil?

Obedecerá (dizem as notícias) aos moldes da de Letras. Por ai já se pode calcular o que vai ser. Uma cousa incitil, cacete e tola. Ainda por dos os dias morrem no Bragil if vreiros portugueses sem herdesross necessurios.

Acabará como o seu modelo presidido pelo greco-maranhense Coelho Netto com um manifesto aos povos pedindo cobres para a hereção de nim grande monumento ao escritor Fulano que por ter sido homem modesto e simples não podo ser imortalizado numa herma. Tal qual.

E vá a gente levar a sério uma cousa assim!

Há mais. A literatura brasileira no seu todo ainda comporta uma academia. Vá lá. Mas o nosso teatro não. Até hoje espera autores. Como poderá ter expoentes?

* *

E que ang $\%$, de caroço fizeram!

No novo cenáculo têm assento autores, compositores, artistas $\theta \mathrm{cr}$. ticos. Quizeram assim arregimentar toda as classes teatrais. E'. Mas se esqueceram de muitas. Faltam ainda representantes da classe dos pontos, dos emprezários, dos bilhoteiros, da claque, dos maquinistas, dos bombeiros de serviço, dos soldados da guarda, dos cenografos, nåo esquecendo os do público, magnânimo coronel paulista de todos eles.

Já existem entre nos a Sociedade Brasileira de Autores Teatrais e a Casa dos Artistas que dăo perfeitamente para o gasto. Năo preciso mais. Autore e actores têm já quem os defenda e trate de seus in. teresses.

A Academia é portanto uma inutilidade. Nos precisamos é de uma Academia Circense. Ao menos para encaminhar devidamente tantos elementos magnificos que estão se perdendo por ai com fundações de cenáculos e outras baboseiras teatrais.

Uma piada enfim. Mas daquelas que quando a gente ouve não sabe se são para rir, chorar ou então dar pancada nos autores.

$\mathrm{Na}$ duvida o mais acertado

Artigo de Antonio de Alcântara Machado.

Fonte: Terra Roxa e Outras Terras. SP. n. 04, 27/04/1926, p. 05. 

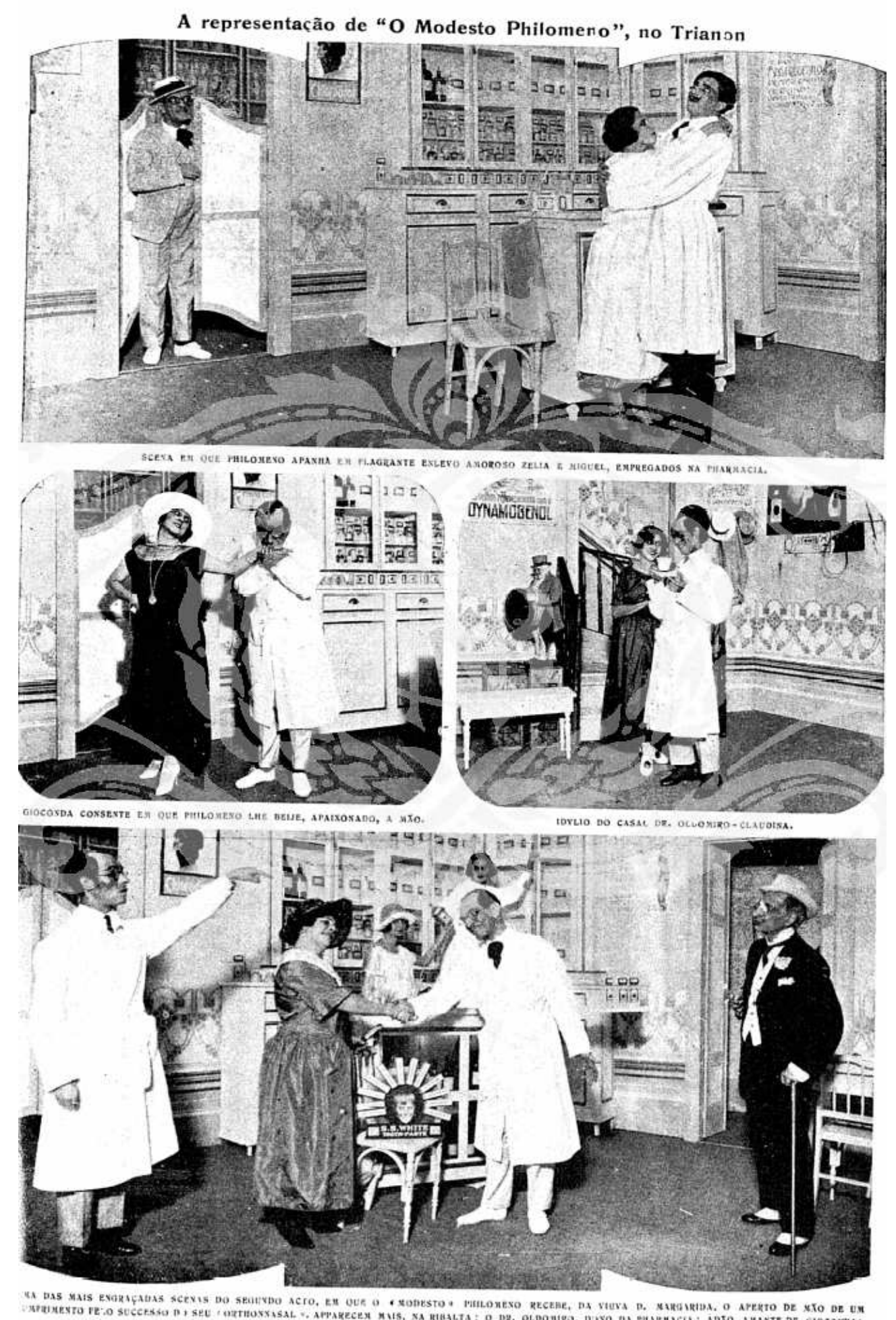

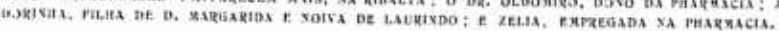

Fotos da representação da peça $O$ Modesto Filomeno, de Gastão Tojeiro, em cartaz no Trianon. Fonte: Fon Fon, RJ, Ano XVI, n. 46, 18/11/1922. (Site da Biblioteca Nacional). 


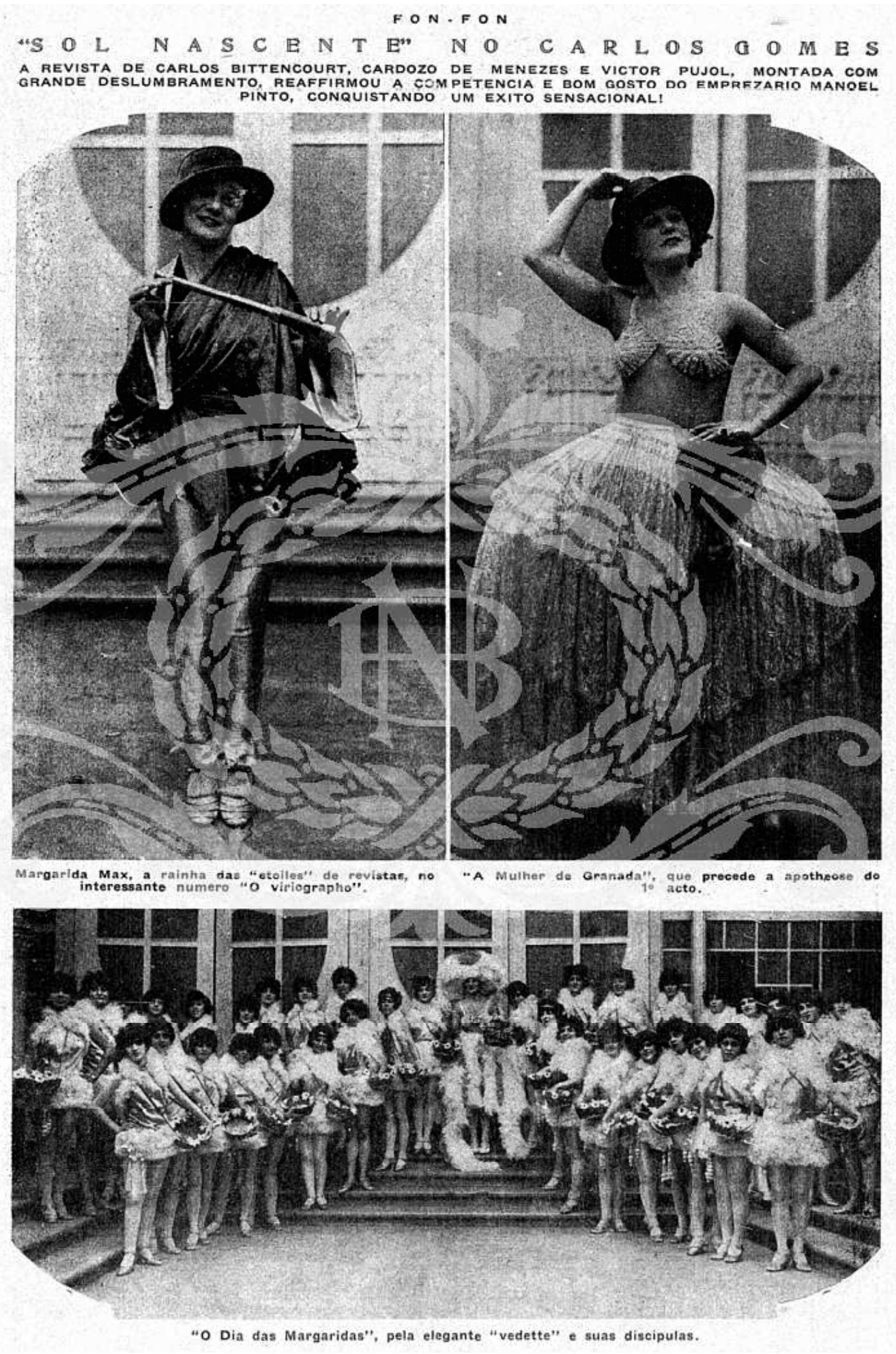

Fotos da representação da revista $O$ Sol Nascente, de Carlos Bittencourt, Cardoso de Menezes e Alfredo Pujol, em cartaz no Carlos Gomes. Fonte: Fon Fon, RJ, Ano XX, n. 45, 06/11/1926. (Site da Biblioteca Nacional). 


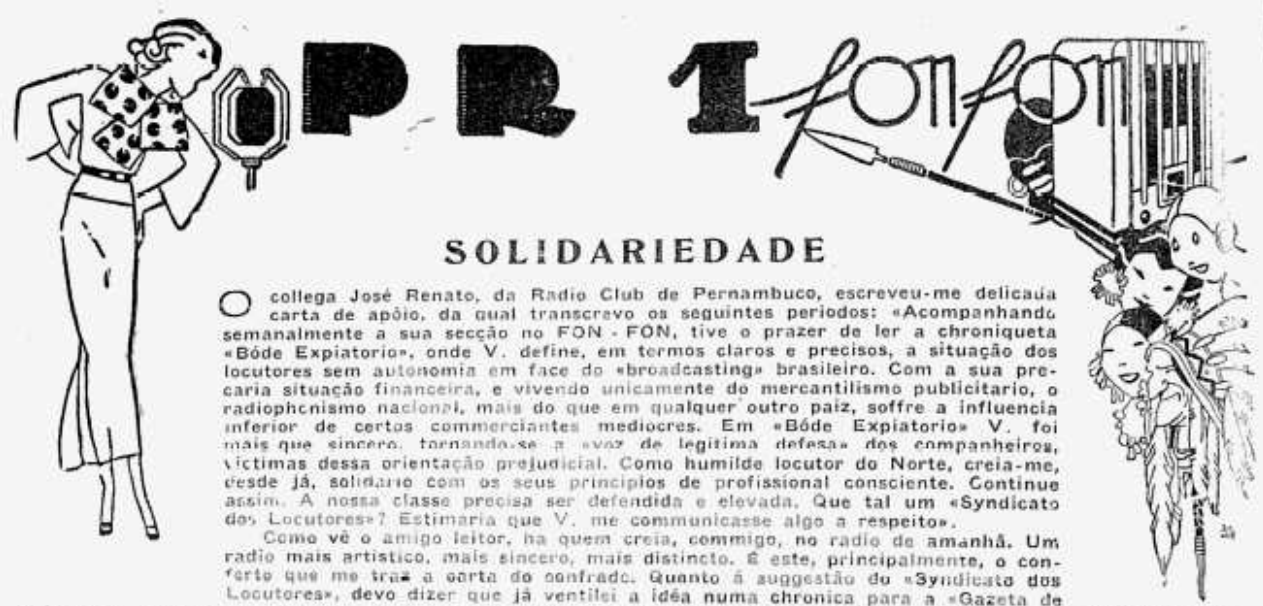
Noticiass, intituiada .Christo ao Microphona.... Mas ventilei-a pensando na .Messianeida de Hermes.Fonte

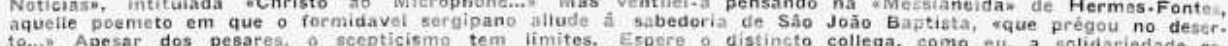

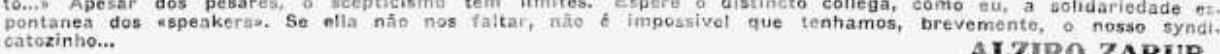

ALZIRO ZARUR

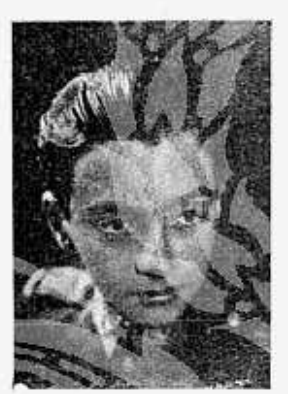
OCTAVIO MARIOT FO. garoto que organiza, dirt. kers, a interessante Hora Infantits da PA C - 2,

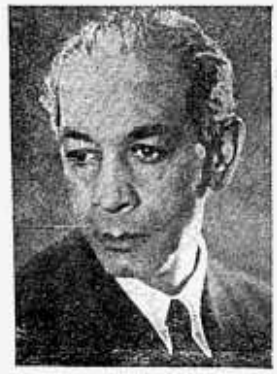

MARCELLO TUPYNAM. ordem do radio paulista, uccōs musicaes, 6 am pro. melihores compositores do nusso ebroadcasting.

$-28-$

\section{A R I A S}

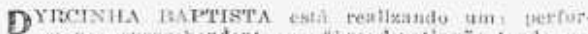

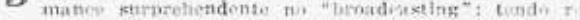

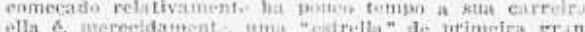

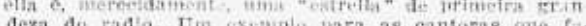
dem an ada, Tom exrmina bera as

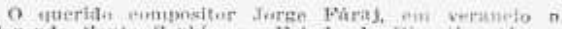

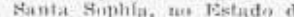

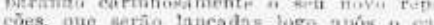

A Radio Guanatiaria tem upresontudo Interessantia pro-

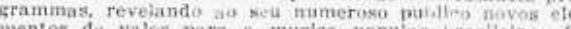

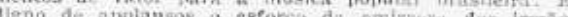

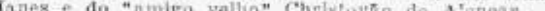

A burleta carnavalesza de Sady Cabra1 - Fiorishella", espechalmente eseripta, em eplsodtos. mara an "Rtrecente suecesso do veterano cartiz ratioptionlo mals presenta uma victorla para edse matrifileo actor-anto que é Sady Cabrut. ...

Ha um lotatior bahlano, entre nos, que deve ser apro vertado pelas entucōes cariocas: trati-so de Eduard sionat consolencloso que póde hourar o "enst" ae grofisquer emlssora.

$$
\text { . }
$$

Segundo nog eonsta, Almirante assimnou contraclo de sa PRD-2, e Celso Gulmareses Irâ para a Record em substltuicáo a Octavio Gabus Mendes, que ingresso

$$
* \cdot
$$

Fula-se, tambem, que Oduvaldo Cozzl substltuira Ar portivo na Cruzeiro do Sal, peineipalmente no secto estorgo de Ayiton Flotes, esplrito agilimo em report mem taes beticto, apesar da bil jarde. Ciso se confitgrandes elemeitos dre

FON - FON

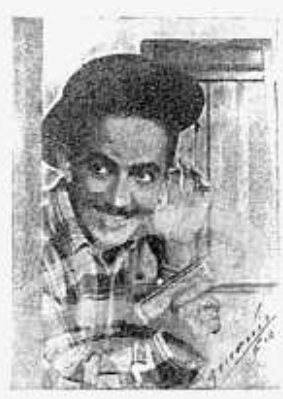

XEREM, que se popular zou do lado du si trabaihando sózinto. augmentou consideravet
mente o seu cartaz de hu
morista na Tupl do Rio

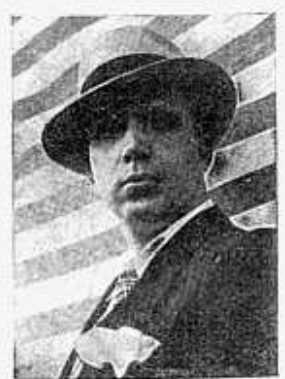

A RY KERNER, terte!ado Anspiradas, de compusiggétes da sua bella sensibitidade. continúa fazendo letras bonitas para as musicas estrangeiras de guccesso. $11-3-939$

Fonte: Fon Fon, RJ, Ano XXXIII, n. 06, 11/02/1939. (Site da Biblioteca Nacional). 


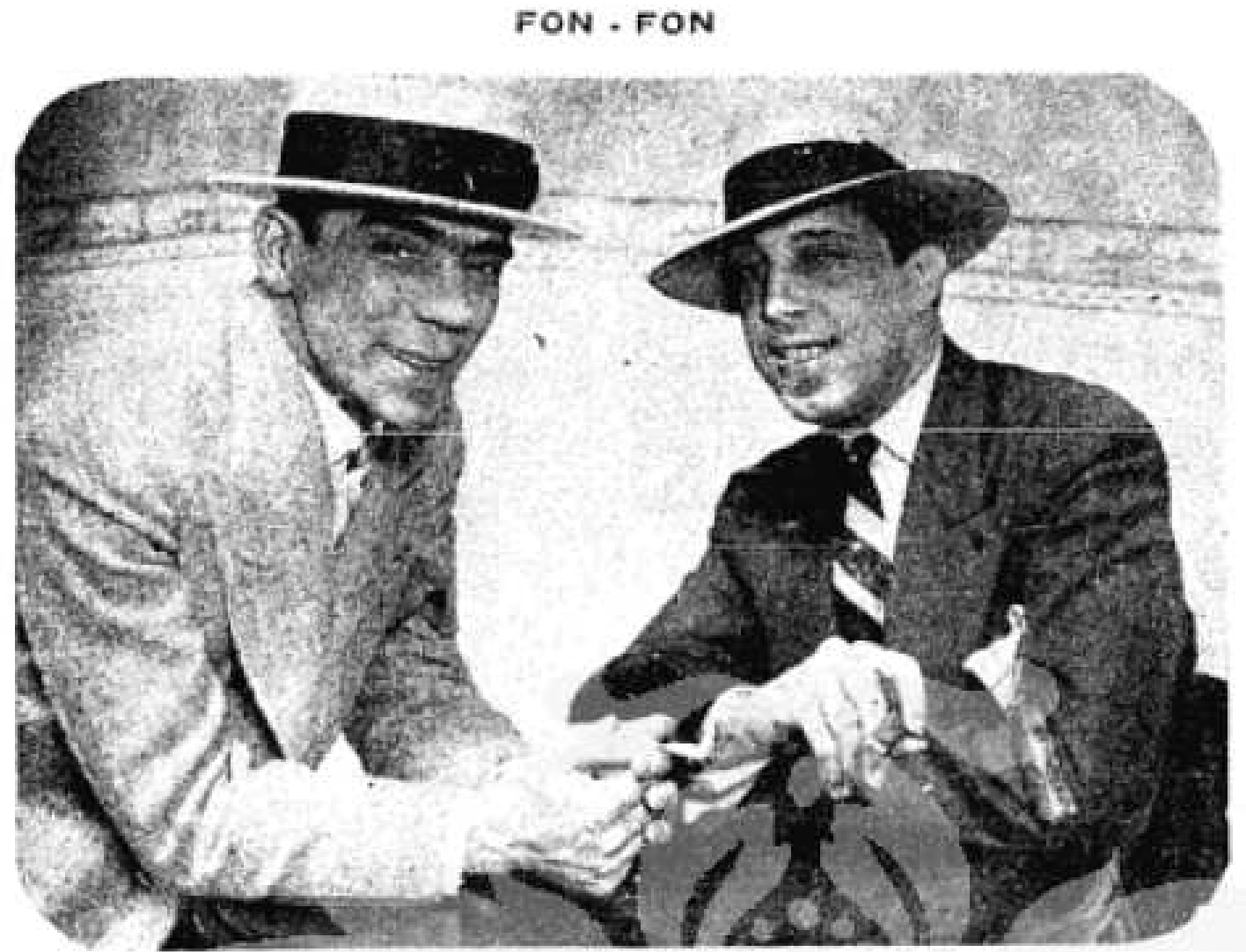

PAULo de wagalhacs e Procopio Ferreira, que estāo novamente Juntos, aqui e... no cartaz do Trianon... vo querido das mu. theress é a nova comedia do primeiro, que o sogundo leu, gostou e poz á scena na boiten da Avonida. Paulo completa, com essa de agora, quarenta peças representadas no Brasif e oito no es. tranceiro. Por isso é gue elle se julga (e sua sposen está revelando, mau grado o sorrico incredulo do Procopio) 0... querido das mulheres...

Paulo de Magalhães e Procópio Ferreira

Fonte: Fon Fon, RJ, Ano XXIII, n. 15, 13/04/1929. (Site da Biblioteca Nacional) 


\section{Introdução}

"Um dos aspectos mais importantes da investigação e da pesquisa histórica, sem mencionar os levantamentos, em arquivos e bibliotecas, de inéditos e dispersos e de éditos que exigem edições criteriosas, a partir da fixação dos textos, é o estudo da evolução das idéias críticas, atitudes e preferências que marcam e caracterizam os sucessivos movimentos literários entre nós, já não digo desde o período colonial, mas sobretudo do Romantismo para cá. Nesse caso, o campo principal a ser explorado é sem dúvida o representado pelos periódicos - revistas e jornais, tidos como expressão de 'grupo literário' fechado ou aberto, nos limites ou não de sua respectiva geração. E do século XIX para cá, periódicos se contam às dezenas, sobretudo quando chegamos ao Movimento Modernista, ainda atuante nos nossos dias. Eles se impõem em dois centros principais - Rio de Janeiro e São Paulo - mas se apresentam também importantes para uma visão totalizadora dos movimentos literários em âmbito nacional em vários outros centros ditos provincianos, por toda a extensão do Brasil" ${ }^{1}$.

${ }^{1}$ CASTELLO, José Aderaldo. "A Pesquisa de Periódicos na Literatura Brasileira”.In: NAPOLI, Roselis Oliveira de. Lanterna Verde e o Modernismo. São Paulo: IEB/USP, 1970. 
A pesquisa em periódicos tem revelado, ao longo do tempo, preciosas fontes de informações e materiais indispensáveis para cobrir certas lacunas nos estudos já existentes. Por meio da pesquisa sistemática em fontes primárias, podemos não apenas conhecer o ideário de um único grupo, mas também apreender uma visão mais ampla de toda uma geração.

As palavras de José Aderaldo Castello, citadas acima, influenciou-nos de várias maneiras na elaboração deste projeto. Inicialmente, entendemos que antes dos livros de história, há a própria História; que antes de relatos e análises posteriores, há a expressão calorosa do momento e registros feitos por aqueles que lá estiveram, sem nenhuma distância temporal ou emocional dos fatos. Assim, buscar a história em sua fonte primeira tornou-se a direção central deste trabalho, que tem por objetivo investigar o teatro brasileiro nas décadas de 20 e 30, a partir de um levantamento de tudo o que foi publicado sobre o assunto nos principais periódicos que circularam entre 1922 e 1942.

A vida teatral da primeira metade do século $\mathrm{XX}$ vem despertando em vários pesquisadores um curioso interesse pela tão criticada "decadência" ou "lacuna" que separou as grandes produções do século XIX até a estréia de Vestido de Noiva, de Nelson Rodrigues, em 1943. A busca dessa crise teatral está gerando investigações e análises mais profundas do período, reconstruindo o caminho percorrido pelo teatro brasileiro e suas relações com a formação e desenvolvimento do país. As fontes e os métodos de investigação utilizados demonstram o cuidado e a preocupação em reconstituir esse período de forma imparcial, trazendo à luz toda a produção teatral e as discussões em torno do processo de modernização do nosso teatro.

Assim, localizamos alguns trabalhos que abordaram o teatro do início do século $\mathrm{XX}$ de modo a coletar indícios que facilitassem nosso caminho. Claudia Braga, em sua dissertação Em Busca da Brasilidade: Teatro Brasileiro na Primeira República, investiga e avalia o teatro do período por meio da análise de textos dramatúrgicos que efetivamente foram levados à cena. Tiago de Mello Gomes, em Um Espelho no Palco: Identidade Sociais e Massificação da Cultura no Teatro de Revista dos Anos 1920, mapeia, por meio do gênero teatro de revista em voga no Rio de Janeiro dos anos 20, o campo social que 
permitiu o surgimento de novas visões sobre a identidade carioca, brasileira e afrobrasileira, destacando novas concepções de gênero, classe, raça, nação e identidade. Ângela Reis, em seu trabalho Cinira Polônio, a Divette Carioca: estudo da imagem pública e do trabalho de uma atriz no teatro brasileiro da virada do século XIX, remonta por meio de uma pesquisa historiográfica a construção da imagem pública da atriz e a participação das mulheres de teatro do início do século XX. Os trabalhos de Maria Filomena Vilela, sobre a companhia de Paschoal Segretto, e de Daniel Marques da Silva, sobre a composição do personagem-tipo através das burletas de Luís Peixoto, ambos realizados na Uni-Rio, também abordam o teatro da época em questão.

Para contribuir e ampliar esse conjunto de pesquisas sobre a época "decadente" do teatro brasileiro, escolhemos como fonte primária de investigação as revistas, por se tratar de um impresso valorizado que documenta o passado por meio de um amplo registro: textual, iconográfico e extratextual. Partimos então do objetivo de extrair a História na sua manifestação primeira, na tentativa de apreender os fatos a partir de testemunhos daqueles que, sem o distanciamento temporal, viviam, construíam e pensavam o teatro nacional. Por constituírem formas de comunicação de informações e idéias de um determinado momento histórico, os periódicos revelam-se como um rico material na busca de um tempo único, criado na pressa do curto espaço de tempo que separa as tiragens. Como aponta Miriam Moreira Leite, em seu estudo sobre periódicos, "a aproximação do presente e do cotidiano reveste o periódico de uma forma testemunhal que pode escapar a publicações mais cuidadas e elaboradas" 2 .

Por outro lado, reconhecemos o caráter ilusório que essa configuração do passado pode ter. Se o estudo dos periódicos não for acompanhado de uma investigação e decodificação cautelosa, ele poderá refletir imagens falsas ou disformes do passado que se pretende reconstruir. Ana Luisa Martins nos aponta que:

O gênero é privilegiado notadamente pelo historiador que, ao simples folhear dessas publicações de época, sente-se envolvido pelo tempo pretérito que busca reconstruir. Imagem, texto, reclames e seções ali contidas, em princípio, independente de análise mais profunda, evocam em seu conjunto, de imediato, o quadro histórico em que se

\footnotetext{
${ }^{2}$ LEITE, Miriam Lifchitz Moreira. "O Periódico: Variedade e Transformação”. Anais do Museu Paulista. Tomo XXVIII, São Paulo: Universidade de São Paulo, 1977/1978. p. 141.
} 
pretende transitar. Contudo, a fonte requer cuidados. Na verdade, os apelos que transportam e induzem o pesquisador a configurações quase pictóricas do passado, tal como um espelho disforme, refletem imagens falsas, imagens de superfície, que requerem investigação e decodificação. ${ }^{3}$

Dessa forma, a pertinência do gênero revista como testemunho de um determinado período só é valida se levarmos em consideração as condições de sua produção, negociação, circulação, das técnicas utilizadas e, principalmente, da natureza dos capitais nele envolvidos.

Buscamos, com este mergulho nas revistas literárias e culturais que circularam entre 1922 e 1942, fazer um registro dos principais acontecimentos, opiniões, discussões e realizações da vida teatral brasileira, levando em consideração as condições de produção dos periódicos analisados e a organização social, cultural e econômica do país. Entendemos que esse registro não será uma análise conclusiva, já que não estamos analisando o corpo completo da cena cultural do país; nossa intenção é fazer um recorte que nos possibilite compreender este conturbado momento da história do teatro nacional, cotejando com estudos já existentes e contribuindo com possíveis desdobramentos do que já se conhece.

Pretendemos, com o olhar mais abrangente e com o diálogo com aquilo que já foi publicado sobre o período, manter uma visão imparcial em nossa análise, afastando-nos das considerações unilaterais sobre $\mathrm{o}$ assunto.

Nosso ponto de partida deu-se com a localização de revistas literárias e culturais que apresentam materiais relacionados ao tema determinado. Balizamos nossa pesquisa entre os anos de 1922 (marco inicial do movimento Modernista) e 1942 (ano que antecede a estréia de Vestido de Noiva, de Nelson Rodrigues). Com efeito, nos deparamos com diversas publicações oriundas da expressão modernista; entretanto, não nos limitamos a pesquisar somente este material, mas sim, abranger uma grande parte de periódicos, independentemente de sua natureza, local ou duração.

Convém destacar que alguns periódicos pesquisados extrapolam um pouco as delimitações de 1922 e 1942. Isso aconteceu com as revistas que ou tiveram sua data de início muito próxima a 22 - como Leitura para Todos que começou a circular em 1919 -

\footnotetext{
${ }^{3}$ MARTINS, Ana Luisa. Revistas em Revistas: Imprensa e Práticas Culturais em Tempos de República (1890-1922). São Paulo: Editora da USP: Fapesp: Imprensa Oficial do Estado, 2001. p. 21.
} 
ou com aquelas que tiveram sua data de término logo após 42 - como Lanterna Verde (1944), Revista do Brasil (1944), Clima (1944) e Cultura Política (1945). Já que tomamos como parâmetro dois recortes literários, ampliamos a pesquisa nos periódicos citados acima na tentativa de encontrar alguma mudança significativa no ponto de vista daqueles que pensavam a vida artística e cultural da época. Queríamos registrar se as publicações que sucederam 1922 foram afetadas e/ou influenciadas pela Semana de Arte Moderna e se houve algum tipo de repercussão da representação de Vestido de Noiva após 1943. Longe de ser o objetivo primeiro deste trabalho, esse registro além dos limites estabelecidos contribuiu com indícios para nossa análise interpretativa das publicações acima.

Concluída a fase de pesquisa, decidimos, então, organizar os dados levantados em um índice classificatório para facilitar não apenas nossa interpretação e análise, mas também para deixar um registro que auxiliará futuras pesquisas de estudiosos que poderão consultálo e ganhar tempo durante suas investigações.

O modelo do índice utilizado foi desenvolvido por José Aderaldo Castello para as pesquisas realizadas por seus orientandos de Mestrado e Doutorado no estudo dos periódicos modernistas ${ }^{4}$. Nesses trabalhos - alguns publicados como livros - estudava-se, por exemplo, uma revista do pré-Modernismo, ou do Modernismo, a partir da qual se faziam reflexões em torno de um determinado contexto literário e cultural. Em seguida, um minucioso índice por assunto informava o leitor sobre o conteúdo de cada número da revista em questão. A diferença em relação a esses trabalhos é que não será apresentado aqui o estudo de uma única revista, mas o estudo de um assunto - o teatro brasileiro - nas revistas das décadas de 20 e 30.

Diversos títulos foram consultados durante a pesquisa, mas nem todos apresentaram material relevante para nosso estudo. A pesquisa foi realizada nos seguintes acervos: Biblioteca Central da Faculdade de Filosofia, Letras e Ciências Humanas, da Universidade de São Paulo; Biblioteca do Instituto de Estudos Brasileiros, da Universidade de São Paulo; Arquivo do Estado de São Paulo; Biblioteca Municipal Mário de Andrade, em São Paulo; Fundação Biblioteca Nacional, no Rio de Janeiro e Sociedade Brasileira de Autores Teatrais, também no Rio de Janeiro. De todo material consultado, selecionamos 28 periódicos para compor nossa pesquisa:

\footnotetext{
${ }^{4}$ CASTELlO, José Aderaldo. Op. cit. pp. 3-12.
} 
1. Klaxon: Mensário de Arte Moderna

2. Novíssima

3. Estética

4. A Revista

5. Terra Roxa e Outras Terras

6. Festa

7. Verde

8. Revista de Antropofagia

9. Movimento

10. Movimento Brasileiro

11. Revista Nova

12. Lanterna Verde

13. Fon Fon

14. Ilustração Brasileira

15. Revista da Academia Brasileira de Letras

16. Revista do Brasil

17. Leitura para Todos

18. A Cena Muda

19. Boletim da Sociedade Brasileira de Autores Teatrais (SBAT)

20. Mundo Literário

21. Frou Frou

22. Boletim de Ariel

23. Revista Brasileira

24. Dom Casmurro

25. Anuário Brasileiro de Literatura

26. Mensagem: Quinzenário de Arte e Cultura

27. Cultura Política

28. Clima 
A partir do roteiro proposto por Castello, tentamos elaborar um índice que abrangesse o tópico da nossa pesquisa e que desse conta das diversas naturezas das informações encontradas. É importante ressaltar que o índice utilizado nas pesquisas orientadas por Castello nos serviu de base e modelo para a elaboração de um índice nosso, com itens relevantes ao estudo do teatro em revistas diversas. Seguimos a mesma estrutura para delinear tópicos e sub-tópicos que foram surgindo no decorrer da pesquisa, na medida em que as informações coletadas iam se tornando frequientes e apresentando naturezas semelhantes. Partimos do pressuposto de que iríamos encontrar peças e matérias relacionadas ao teatro; entretanto, nos surpreendemos ao encontrar tantas fotos e ilustrações sobre o assunto. Assim, após a conclusão da pesquisa, chegamos ao seguinte índice classificatório:

1. Peças teatrais

2. Noticiário

2.1. Notícias e Notas (informações relativas ao universo teatral como um todo: artistas, autores, companhias etc)

2.2. Resenhas (de livros e de peças nacionais e estrangeiras)

3. Crítica Teatral (posição de alguns intelectuais em relação à produção teatral da época)

3.1. Sobre o teatro estrangeiro

3.2. Sobre o teatro nacional

3.3. Sobre a modernização do teatro (nacional e estrangeiro)

3.4. Sobre um ator/ dramaturgo/ diretor

3.5. Sobre uma peça

4. Conferências, entrevistas e manifestos.

5. Fotos e ilustrações (de atores, diretores e dos teatros da época) 
O primeiro tópico, intitulado Peças teatrais, registra as peças ou trechos de peças teatrais publicados nos periódicos pesquisados. O segundo abrange todo o noticiário da época, incluindo notas, resenhas, anúncios e notícias sobre a vida teatral e as peças que estavam em cartaz.

O terceiro - Crítica teatral - é um tópico mais amplo que visa registrar a posição dos intelectuais em relação à produção teatral, considerando tanto o teatro estrangeiro quanto o nacional. Tentamos separar os artigos que tratam especificamente da modernização do teatro, não apenas as tentativas de renovação do teatro nacional, mas também as realizações do teatro estrangeiro e de que modo elas eram vistas e recebidas pelos críticos brasileiros. Ainda neste tópico, incluímos os artigos que tratam de algum determinado autor, ator ou diretor, de modo a destacar os principais responsáveis pela organização da vida teatral e suas realizações. O último sub-tópico classifica as críticas dedicadas às peças que estavam em cartaz, considerando performance dos artistas e relevância do texto teatral.

O quarto tópico abrange todas as conferências, entrevistas e manifestos proferidos por algum integrante da vida teatral; e o quinto, fotos ou ilustrações de atores, autores ou diretores de sucesso.

Dessa forma, cada matéria terá o número da respectiva revista, juntamente com o número do índice classificatório. Exemplificando, uma peça teatral publicada na revista Estética, será indicada da seguinte forma:

\section{1.1 .}

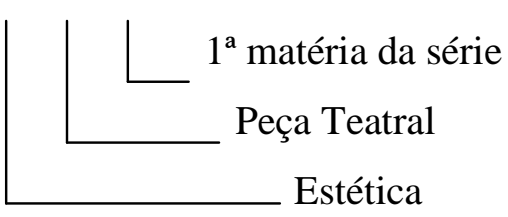


Uma crítica teatral sobre o teatro nacional publicado na revista Dom Casmurro terá a indicação:

24. 3. 2. 1 .

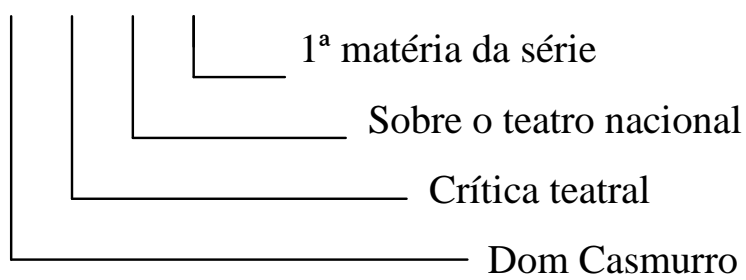

É importante ressaltar que, apesar de termos realizado uma pesquisa minuciosa nos periódicos encontrados, sabemos que não esgotamos todas as possibilidades de pesquisa, nem mesmo registramos todas as ocorrências relacionadas ao assunto, principalmente em periódicos semanais, nos quais a grande quantidade de dados levou-nos a optar pela seleção dos mais relevantes.

Terminada a etapa do levantamento dos dados e de sua organização no índice, iniciamos a segunda etapa do projeto que consiste na análise e interpretação dos dados coletados a fim de desenvolver um estudo do teatro brasileiro da época delimitada, apresentando as principais contribuições e discussões dos intelectuais não apenas sobre a situação do teatro nacional, mas também sobre a possível modernização dos nossos palcos, bem como a influência do teatro estrangeiro. A intenção é de ampliar os estudos já existentes com eventuais contribuições e/ou descobertas do nosso levantamento.

Dessa forma, o primeiro capítulo deste trabalho apresentará um estudo analíticointerpretativo dos dados coletados, destacando as principais contribuições de cada periódico pesquisado. Para facilitar nossa análise, os periódicos foram agrupados em dois grandes grupos: 1- Revistas Modernistas; 2- Outras Revistas. Essa divisão nos possibilitou identificar linhas de pensamento semelhantes, tanto por parte dos críticos e intelectuais, quanto daqueles que faziam teatro no Brasil.

Partimos das condições de produção dos periódicos em questão para então abordar o posicionamento de cada grupo de intelectuais e artistas e o modo pelo qual as realizações do teatro nacional eram abordadas. Antes de nos aprofundarmos no objetivo acima, delineamos a questão da censura acerca da produção periódica a partir da implementação do Estado Novo em 1937 e suas influências na natureza das informações publicadas. 
Essa análise detalhada das contribuições de cada revista possibilitou a abertura de novos caminhos para este estudo. A partir das informações encontradas, acrescentamos a esta dissertação mais dois capítulos. O segundo capítulo destaca os principais nomes do nosso teatro das décadas de 20 e 30 , considerando as companhias, os atores e os dramaturgos que efetivamente ocuparam os palcos da cena nacional. Essa análise considera as condições de produção e as temáticas das peças constantemente em cartaz, a formação dos atores de sucesso e a estruturação das companhias teatrais. Nosso principal objetivo neste momento não é apenas demonstrar que havia sim uma importante vida teatral no período em questão, mas também verificar de que modo a crítica se posicionava frente às essas realizações.

Partindo desse panorama da produção teatral das décadas de 20 e 30, o terceiro capítulo pretende discorrer sobre as diversas disputas artísticas existentes naquela época que tinham como foco a arte teatral. Assim, buscamos apresentar as discussões em torno da disputa cinema versus teatro, considerando as diversas opiniões a respeito desse embate e as suas implicações na evolução teatral brasileira. Além disso, será analisado de que forma o teatro ganhou força e espaço nas ondas radiofônicas e qual a contribuição do rádio-teatro para a história do teatro nacional.

Por fim, apresentamos uma análise feita mais de perto das pontuais realizações de caráter e/ou intenções modernas que ocorreram ao longo dos anos aqui pesquisados. Pretendemos entender de que modo essas realizações contribuíram para o processo de afirmação da cena moderna nacional e a sua repercussão na imprensa periódica da época. Partindo do estabelecimento do projeto modernista, serão consideradas as contribuições tanto de caráter crítico quanto as de criação e de experimentação, tendo como pano de fundo as transformações político-sociais que ocorreram no período.

A segunda parte deste trabalho apresentará o índice das matérias publicadas, dividido nos mesmos grupos já definidos no capítulo 1. Não há no índice nenhuma informação adicional sobre os periódicos além dos registros dos dados coletados. Por isso, acreditamos ser necessário o desenvolvimento de uma ficha técnica para cada periódico pesquisado, registrando informações do tipo: período e números pesquisados, local de publicação, fonte, direção etc. Segue então abaixo a ficha de cada periódico organizado na mesma ordem do índice. 


\section{Ficha Técnica dos Periódicos Pesquisados}

\section{Klaxon}

Subtítulo: Mensário de Arte Moderna

Local de Publicação: São Paulo

Direção: indicada apenas com a palavra 'A Redação'

Duração: maio de 1922 a janeiro de 1923

Números pesquisados: todos

Periodicidade: mensal

Principal crítico teatral: não há

Fonte: Edição fac-similada de 1972 - Biblioteca Central da FFLCH/USP - São Paulo

\section{Novíssima}

Local de Publicação: São Paulo

Direção: Cassiano Ricardo e Francisco Pati

Duração: dezembro de 1923 a jun/jul de 1926

Números pesquisados: n. 01, 02, 04, 06, 07 e 08 - Ano 1

Periodicidade: mensal até fev/1924 e bimestral até jun-jul/1926

Principal crítico teatral: não há

Fonte: Microfilme - Biblioteca Pública Municipal de São Paulo

\section{Estética}

Local de Publicação: Rio de Janeiro

Direção: Prudente de Moraes Neto e Sérgio Buarque de Holanda

Duração: setembro de 1924 a junho de 1925

Números pesquisados: n.01 (set/24) ao n.03 (abr-jun/25)

Periodicidade: irregular

Principal crítico teatral: não há

Fonte: Original - Biblioteca do IEB - São Paulo 


\section{A Revista}

Local de Publicação: Belo Horizonte - MG

Direção: Martins de Almeida e Carlos Drummond de Andrade

Duração: julho de 1925, agosto de 1925 e janeiro de 1926

Números pesquisados: os três números da revista

Periodicidade: irregular

Principal crítico teatral: não há

Fonte: Biblioteca Central da FFLCH/USP - São Paulo

\section{Terra Roxa e Outras Terras}

Local de Publicação: São Paulo

Direção: Antonio de Alcântara Machado e A. C. Couto de Barros

Duração: janeiro de 1926 a setembro de 1926

Números pesquisados: todos os sete números publicados

Periodicidade: irregular

Principal crítico teatral: Antonio de Alcântara Machado

Fonte: Edição fac-similada de 1977 - Biblioteca Central da FFLCH/USP - São Paulo

\section{Festa}

Subtítulo: Mensário de Arte e Pensamento

Local de Publicação: Rio de Janeiro

Direção: Tasso da Silveira e Andrade Murici

Duração: out/1927 a set/1928 ( ${ }^{\text {a }}$ fase) e jul/1934 a ago/1935 ( $2^{\text {a }}$ fase)

Números pesquisados: todos da $1^{\mathrm{a}} \mathrm{e} 2^{\mathrm{a}}$ fase.

Periodicidade: mensal

Principal crítico teatral: Não há

Fonte: Original - Biblioteca do IEB - São Paulo 


\section{Verde}

Subtítulo: Revista Mensal de Arte e Cultura

Local de Publicação: Cataguases - MG

Direção: Henrique de Rezende

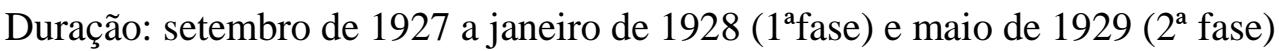

Números pesquisados: n.01 (set/27) ao n.05 (jan/28) e n.01 (mai/29)

Periodicidade: mensal, com exceção no n.01 da $2^{\mathrm{a}}$ fase que foi publicado após quinze meses de interrupção e não teve continuidade.

Principal crítico teatral: não há

Fonte: Original - Biblioteca Central da FFLCH/USP - São Paulo

\section{Revista de Antropofagia}

Local de Publicação: São Paulo

Direção: Antonio de Alcântara Machado e Raul Bopp ( $1^{\mathrm{a}}$ fase) e Geraldo Galvão Vaz $\left(2^{\mathrm{a}}\right.$ fase $)$

Duração: mai/1928 a fev/1929 ( $1^{\text {a }}$ fase) e 17/03/1929 a 01/08/1929 ( $2^{a}$ fase)

Números pesquisados: todos da $1^{\mathrm{a}}$ e $2^{\mathrm{a}}$ fase

Periodicidade: mensal ( $1^{\text {a }}$ fase $)$ e semanal ( $2^{\mathrm{a}}$ fase $)$

Principal crítico teatral: não há

Fonte: Edição fac-similada de 1976 - Biblioteca Central da FFLCH/USP - São Paulo

\section{Movimento}

Subtítulo: Revista de Crítica e Informação

Local de Publicação: Rio de Janeiro

Direção: Renato Almeida

Duração: outubro de 1928 a dezembro de 1928

Números pesquisados: n.01 (out/28) ao n.03 (dez/28)

Periodicidade: mensal

Principal crítico teatral: Antonio de Alcântara Machado

Fonte: Original - Biblioteca do IEB - São Paulo 


\section{Movimento Brasileiro}

Subtítulo: Revista de Crítica e Informação

Local de Publicação: Rio de Janeiro

Direção: Renato Almeida

Duração: janeiro de 1929 a setembro de 1930

Números pesquisados: n.01 (jan/29) ao n.21 (set/30)

Periodicidade: mensal

Principal crítico teatral: não há

Fonte: Original - Biblioteca do IEB - São Paulo

\section{Revista Nova}

Local de Publicação: São Paulo

Direção: Paulo Prado, Mário de Andrade e Antonio de Alcântara Machado

Duração: 15 de março de 1931 a 15 de dezembro de 1932

Números pesquisados: n.01 (15/03/31) ao n.10 (15/12/32)

Periodicidade: irregular

Principal crítico teatral: Antonio de Alcântara Machado

Fonte: Original - Biblioteca do IEB - São Paulo

\section{Lanterna Verde}

Subtítulo: Boletim da Sociedade Felipe d'Oliveira

Local de Publicação: Rio de Janeiro

Direção: Rodrigues Otávio Filho, Otávio Tarquínio de Souza, Ribeiro Couto e João

Daudt d'Oliveira (Comissão Diretora da Sociedade).

Duração: $1^{a}$ fase: 1934 a 1938 - 2a fase: 1943 a 1944

Números pesquisados: todos

Periodicidade: irregular

Principal crítico teatral: Álvaro Moreyra

Fonte: Original - Biblioteca do IEB - São Paulo 


\section{Fon Fon}

Local de Publicação: Rio de Janeiro

Direção: Álvaro Moreyra e Raul Pederneiras

Duração: 1907 a 1958 ?

Números pesquisados: n.01 (jan/22 - Ano XVI) ao n. 52 (dez/1942 - Ano XXXVI)

Periodicidade: semanal

Principal crítico teatral: Oscar D’Alva, Zarur Alzir e Gomes Filho.

Fonte: Microfilme - Biblioteca Central da FFLCH/USP - São Paulo

\section{Ilustração Brasileira}

Local de Publicação: Rio de Janeiro

Direção: Álvaro Moreyra e José Carlos

Duração: 1909 a 1953

Números pesquisados: 1921 a 1942

Periodicidade: quinzenal

Principal crítico teatral: não há

Fonte: Original - Biblioteca Central da FFLCH/USP e Biblioteca do IEB - São Paulo

\section{Revista da Academia Brasileira de Letras}

Local de Publicação: Rio de Janeiro

Direção: Presidente da Academia nomeado a cada ano

Duração: 1910 a 1973

Números pesquisados: n.21 (1922) ao n.140 (1942)

Periodicidade: trimestral

Principal crítico teatral: não há

Fonte: Original - Biblioteca Central da FFLCH/USP

\section{Revista do Brasil}

Subtítulo: Mensário de Arte Moderna

Local de Publicação: São Paulo e Rio de Janeiro 
Direção: entre eles, Monteiro Lobato, Ronald de Carvalho e Brenno Ferroz ( $1^{\mathrm{a}}$ fase), Plínio Barreto, Afrânio Peixoto ( $2^{\mathrm{a}}$ fase), Otávio Tarquínio de Souza ( $3^{\mathrm{a}}$ fase) e Frederico Chateaubriand ( $4^{\mathrm{a}}$ fase)

Duração: jan/1916 a mar/1925 ( $1^{\mathrm{a}}$ fase); set/1926 a jan/1927 ( $2^{\mathrm{a}}$ fase); 1938 a 1943 (3 ${ }^{\mathrm{a}}$ fase) e 1944 ( $4^{\text {a }}$ fase)

Números pesquisados: jan/1922 a abr/1944

Periodicidade: mensal ( $1^{\mathrm{a}}, 3^{\mathrm{a}}$ e $4^{\mathrm{a}}$ fases), quinzenal ( $2^{\mathrm{a}}$ fase)

Principal crítico teatral: Antonio de Alcântara Machado ( $2^{\mathrm{a}}$ fase $)$ e Guilherme Figueiredo ( $3^{\mathrm{a}}$ fase $)$

Fonte: Original - Biblioteca Central da FFLCH/USP e Biblioteca do IEB - São Paulo

\section{Leitura para todos}

Local de Publicação: Rio de Janeiro

Direção:

Duração: desconhecida

Números pesquisados: 1919 a 1928

Periodicidade: mensal

Principal crítico teatral: não há

Fonte: Original - Biblioteca do IEB - São Paulo

\section{A Cena Muda}

Local de Publicação: Rio de Janeiro

Direção: Renato de Castro e posteriormente, Gratuliano Brito

Duração: 1921 a 1955

Números pesquisados: 1921 a 1942

Periodicidade: semanal

Principal crítico teatral: Sylvia Moncorvo

Fonte: Microfilme - Biblioteca Nacional - Rio de Janeiro e Original - Biblioteca da ECA/USP - São Paulo 


\section{Boletim da S.B.A.T.}

Local de Publicação: Rio de Janeiro

Direção: Presidente da Sociedade do ano vigente

Duração: 1924 a 1955

Números pesquisados: n. 01 de 1924 a n. 214 de 1942

Periodicidade: mensal

Principal crítico teatral: não há

Fonte: Original - Biblioteca da Sociedade Brasileira de Autores Teatrais - Rio de Janeiro

\section{Mundo Literário}

Subtítulo: Mensário de Literatura Nacional e Estrangeira

Local de Publicação: Rio de Janeiro

Direção: Pereira da Silva e Théo-Filho

Duração: maio de 1922 a março de 1926

Números pesquisados: todos

Periodicidade: mensal

Principal crítico teatral: não há

Fonte: Original - Biblioteca do IEB - São Paulo ${ }^{5}$

\section{Frou-Frou}

Local de Publicação: Rio de Janeiro

Direção: Antonio Guimarães

Duração: 1923 a 1935

Números pesquisados: $n .01$ (jun/23 - $1^{\mathrm{a}}$ fase) ao $n .11$ (jan/30 - $2^{\mathrm{a}}$ fase)

Periodicidade: mensal

Principal crítico teatral: não há

Fonte: Original - Biblioteca Nacional - Rio de Janeiro

\footnotetext{
${ }^{5}$ Pesquisa complementada com o auxílio da tese de Eneida Maria Chaves, intitulada O Mundo Literário - Um Periódico da Década de 20 no Rio de Janeiro. Vol.2.
} 


\section{Boletim de Ariel}

Subtítulo: Mensário Crítico-Bibliográfico: Letras, Artes e Ciências

Local de Publicação: Rio de Janeiro

Direção: Gastão Cruls

Duração: 1931 a 1939

Números pesquisados: out/1931 a set/1938

Periodicidade: mensal

Principal crítico teatral: José Maria Senna

Fonte: Original - Biblioteca do IEB - São Paulo

\section{Revista Brasileira}

Subtítulo: Síntese do Movimento Contemporâneo

Local de Publicação: Rio de Janeiro

Direção: Baptista Pereira

Duração: $4^{\mathrm{a}}$ fase: 1934 a 1935

Números pesquisados: n.01 (julho/1934) a n.10 (out-nov/1935)

Periodicidade: mensal (n. 01 ao 03) e bimestral (n. 04 ao n.10)

Principal crítico teatral: Saul de Weston

Fonte: Original - Biblioteca do IEB - São Paulo

\section{Dom Casmurro}

Local de Publicação: Rio de Janeiro

Direção: Bricio de Abreu

Duração: 1937 a 1946

Números pesquisados: n.01 (1937) ao n.282 (1942)

Periodicidade: semanal

Principal crítico teatral: LUDO (pseudônimo de Bricio de Abreu)

Fonte: Microfilme - Biblioteca Central da FFLCH/USP - São Paulo 


\section{Anuário Brasileiro de Literatura}

Local de Publicação: Rio de Janeiro

Direção: Rogério Pongetti

Duração: 1937 a 1944

Números pesquisados: vol.01 (1937) ao vol.06 (1942)

Periodicidade: anual

Principal crítico teatral: Bandeira Duarte

Fonte: Original - Biblioteca do IEB - São Paulo

\section{Mensagem}

Subtítulo: Quinzenário de Arte e Cultura

Local de Publicação: Belo Horizonte

Direção: Guilhermino Cesar

Duração: 1939 a 1944

Números pesquisados: n.01 (ago/1939) ao n.09-10 (jul/1941)

Periodicidade: quinzenal

Principal crítico teatral: não há

Fonte: Original - Biblioteca do IEB - São Paulo

\section{Cultura Política}

Subtítulo: Revista Mensal de Estudos Brasileiros

Local de Publicação: Rio de Janeiro

Direção: Almir de Andrade

Duração: abril de 1941 a 1945

Números pesquisados: n.01 (abr/41) ao n.22 (dez/42)

Periodicidade: mensal

Principal crítico teatral: Raimundo Magalhães Júnior

Fonte: Original - Biblioteca Central da FFLCH/USP - São Paulo

\section{Clima}

Local de Publicação: São Paulo.

Direção: Lourival Gomes Machado 
Duração: maio de 1941 a novembro de 1944

Números pesquisados: n.01 (mai/41) a n.11 (dez/42)

Periodicidade: irregular

Principal crítico teatral: Décio de Almeida Prado

Fonte: Original - Biblioteca do IEB - São Paulo

Para sistematizar e organizar os dados da pesquisa, produzimos, ao longo do trabalho, algumas relações para facilitar nossa consulta e permitir uma análise comparativa e quantitativa mais precisa. Por fim, tínhamos quatro importantes documentos que decidimos incluir como anexos nesta dissertação. Fica como registro de um minucioso trabalho de análise e como referência aos pesquisadores interessados. Vale ressaltar que os dados para elaboração dessas relações foram coletados a partir de indicações nas matérias pesquisadas e catalogadas no índice. Esses anexos estão divididos em: a) Relação das peças publicadas; b) Relação das peças que estavam em cartaz; c) Relação das peças que participaram do concurso da Revista da Academia Brasileira de Letras; d) Relação das peças de rádio-teatro irradiadas pelas emissoras. 


\section{1 - Revistas, Boletins e Anuários: Os Periódicos Analisados}

Ao delimitarmos o ano de 1922 como ponto de partida para este estudo, foi natural iniciarmos nossa pesquisa pelos periódicos Modernistas, que já haviam sido a temática central de nosso trabalho de iniciação científica. Material valorizado e de fácil acesso devido aos seus exemplares fac-similados, conseguimos compor nossa análise em 12 periódicos modernistas.

Concluída essa etapa, partimos para a busca de revistas essencialmente sobre teatro que nos permitissem uma análise mais apurada do tema em questão. Registra-se, já no final do século XIX, o surgimento de revistas voltadas à temática teatral. Em São Paulo, o aparecimento da revista Echos Theatrais, em 1895, publicada em noites de espetáculo do Teatro São José, revela essa preocupação em disseminar nos periódicos os acontecimentos da vida teatral da cidade. Com a virada do século, diversas revistas de natureza idêntica foram surgindo de modo a não apenas atrair a atenção do público para os nossos palcos, mas também para divulgar espetáculos e textos para dramatização.

Consultando o livro de Ana Luisa Martins - Revistas em Revistas - e os acervos das bibliotecas anteriormente citadas, elaboramos uma relação dos principais periódicos teatrais que circularam em São Paulo e no Rio de Janeiro, desde os últimos anos do século XIX até as primeiras décadas do XX. Na tentativa de coletar indícios que nos levassem a publicações de mesma natureza publicadas entre 1922 e 1942, chegamos à seguinte listagem:

\section{$\underline{\text { São Paulo }}$}

- 1895: Ecos Teatrais, publicada em noites de espetáculo do Teatro São José;

- 1898: O Guarany - Publicação da Associação de Amadores Dramáticos;

- 1900: A Arte, revista literária e teatral, de publicação do Congresso Luso Brasileiro, sociedade dramática de SP;

- 1902: A Comédia, de Grupo Dramático Alunos de Talma;

- 1903: O Lírico - Conrado Egisto Pucciarelli, proprietário do Teatro Lírico;

- 1903: Arte e Esporte - do mesmo proprietário; 
- 1903: O Palco, proprietário: Porto Lucazek;

- 1904: A Cena, Órgão do Grupo Dramático Recreativo Paulista;

- 1904: Revista Teatral, publicação quinzenal de assuntos teatrais, proprietário: Cunha Irmãos e Cia;

- 1905: Palladium, arte cênica, de Jorge Costa e Andrelino de Paula Assis;

- 1905: O Binóculo, órgão teatral de Emilio Passerini.;

- 1905: O Teatro, da Companhia Dramática Portuguesa;

- 1908: O Amador Dramático, de A.L. Fonseca e Silva;

- 1908: O Palco Ilustrado, da Empresa Malagrini e Nardelli;

- 1909: A Gazeta Artística, de Augusto Barjona;

- 1913: Revista Teatral. Teatro, esporte, arte e... o que for, da Agência Teatral Ítalobrasileira;

- 1914: Éden, revista ilustrada, teatral e cinematográfica, Órgão Oficial da Agência Teatral Brasil, proprietário: F. Loureiro e Cia;

- 1920: Teatros e Diversões, de Pereira Szmeitat;

\section{$\underline{\text { Rio de Janeiro }}$}

- 1895: O Escândalo: Órgão do Mundo Alegre;

- 1896: Semana Teatral: Hebdomadário Ilustrado, de Calainho e Cia;

- 1901: Brasil Teatro;

- 1903: O Guarany. Órgão do Guarany Clube. Direção de Eduardo Magalhães;

- 1903: O Artista: Órgão da sociedade dramática particular Furtado Coelho;

- 1904: O Espectador: Periódico teatral, literário e recreativo;

- 1911: O Teatro. Direção de Nazareth Menezes;

- 1913: A Ribalta. Direção Julio de Amaral;

- 1914: O Bobo. Descrição das peças em representação no Teatro Carlos Gomes;

- 1916: Farpas e Ribalta, Empresa Nunes e Cia.

- 1918: O Binóculo: Semanário teatral, artístico e humorístico, direção de Santos Figueiro;

- 1921: Boletim da SBAT, Órgão da Sociedade Brasileira de Autores Teatrais; 
Apesar do número dessas publicações ter sido elevado, sua duração era efêmera e de baixa tiragem. Mesmo com a diversificação de assuntos, seu caráter teatral não encontrou respaldo suficiente para garantir a ampliação e a continuação de sua produção. Além disso, registra-se também a inclusão de matérias sobre as novidades do cinematógrafo; revistas como O Palco, Revista Teatral, Palladium, arte cênica, O Amador Dramático entre outras, relacionavam teatro com as produções do cinematógrafo, trazendo a listagem dos filmes em exibição e comentários sobre as salas da cidade.

Aos poucos, o cinema tornou-se matéria preferencial dos meios de comunicação, em particular do circuito periódico. A partir de 1908, até pela novidade, conheceu uma verdadeira febre de produção, sendo 1910 considerado seu ano de ouro ${ }^{6}$.

Com a instalação dos estúdios da Universal em Hollywood em 1915 e o aumento das salas de cinemas essa concorrência foi, aos poucos, sendo vencida pelos encantos da tela. Constatamos em nossa busca que as revistas especificamente sobre teatro deixaram de existir com o advento da década de 20. Com exceção do Boletim da S.B.A.T., não encontramos, para a realização de nossa pesquisa, nenhum outro periódico exclusivamente teatral que tenha circulado entre 1922 e 1942. As matérias e notas sobre teatro apareciam, neste período, dentro das revistas literárias e culturais, dividindo espaço com informações políticas e econômicas e com notas sociais e cinematográficas.

Dessa forma, passamos a consultar diversas revistas que circularam no período em busca de material relevante para a elaboração de nosso índice por meio de "pistas" registradas em referências ou citações encontradas no decorrer da pesquisa.

É possível notar que a maior parte das revistas pertence ao eixo Rio - São Paulo, já que essas cidades eram consideradas os pólos da imprensa nacional e por isso tinham uma maior capacidade de publicação. Além disso, a ausência de assuntos relacionados ao teatro em algumas revistas, como Revista Acadêmica e A Pilhéria, de Recife, Arco e Flexa e Samba, da Bahia, Arte Moderna, do Pará e Nossa Terra e Outras Terras, de Natal, dificultou a ampliação da nossa análise. É importante ressaltar também que a dificuldade de

\footnotetext{
${ }^{6}$ MARTINS, Ana Luisa. Op. cit. p. 322.
} 
localização e de acesso aos acervos dos Estados mais distantes contribuiu para a concentração da pesquisa nos periódicos publicados em São Paulo, Rio de Janeiro e Minas Gerais.

Assim, concluída a etapa de levantamento de dados, decidimos, por questões metodológicas, dividir as 28 revistas pesquisadas em dois grandes grupos para facilitar nossa análise. No primeiro grupo foram reunidas as revistas essencialmente 'modernistas', em sua grande maioria, publicadas na década de 20; do segundo fazem parte as revistas de caráter mais popular e de maior circulação, por nós classificadas como 'outras revistas':

\section{1- $\underline{\text { Revistas Modernistas }}$}

- Klaxon

- Novíssima

- Estética

- A Revista

- Terra Roxa e Outras Terras

- Festa

- Revista Verde

- Revista de Antropofagia

- Movimento

- Movimento Brasileiro

- Revista Nova

- Lanterna Verde

\section{2- Outras Revistas}

\section{- Fon Fon}

- Ilustração Brasileira

- Revista da Academia Brasileira de Letras

- Revista do Brasil

- Leitura para Todos

- A Scena Muda

- Boletim da Sociedade Brasileira de Autores Teatrais (S.B.A.T.) 
- Mundo Literário

- Frou Frou

- Boletim de Ariel

- Revista Brasileira

- Dom Casmurro

- Anuário Brasileiro de Literatura

- Mensagem

- Cultura Política

- Clima

Antes de passarmos para a análise propriamente dita de cada grupo, acreditamos ser relevante discorrer sobre as características de cada um deles e as justificativas pelas quais consideramos válido o agrupamento acima.

No período pós-Semana de Arte Moderna, diversos intelectuais resolveram unir esforços e ajuda financeira a fim de criar periódicos que facilitassem a circulação do ideário modernista que precisava consolidar seu projeto e suas bases na vida cultural do país. A intenção de avaliar o movimento e consolidar seus ideais está presente em todos os periódicos modernistas que foram publicados ao longo da década de 20 e alguns, mais tardiamente, na década de 30. Cada revista trazia em si o reflexo de seu momento histórico, o que influenciava diretamente na natureza dos artigos publicados.

As revistas modernistas tinham a função de porta-voz daqueles que propunham mudanças, investigações e experimentações. Klaxon: Mensário de Arte Moderna surgiu como consequiência direta da Semana e buscou mostrar por meio de artigos, críticas de arte, poemas e comentários, todo o espírito modernista.

Klaxon fora a trincheira de que os modernistas em dado momento necessitavam para travar a luta pelo poder intelectual e artístico. Nela exerceram aguerrida polêmica estética, exibiram a sua inteligência e o entendimento que tinham das letras e artes, lançaram a proposta de novos meios de expressão e, num certo sentido, corrigiram os rumos que vinham sendo seguidos, deram os primeiros passos nesta direção ${ }^{7}$.

\footnotetext{
${ }^{7}$ BRITO, Mário da Silva. O Alegre Combate de Klaxon. Introdução da edição fac-similada da revista Klaxon. São Paulo: Livraria Martins, 1972.
} 
As produções aqui reunidas no grupo modernista ancoravam-se em grupos de artistas e intelectuais que, mesmo com poucos recursos, objetivavam a divulgação e consolidação de seus ideais. Por apresentarem um projeto e uma composição de vanguarda, o apoio publicitário era insuficiente para a ampliação das tiragens e para a manutenção da produção, que apresentava uma duração efêmera.

O registro do tema teatral pelas revistas modernistas é bem similar: ou publicavam os acontecimentos do teatro estrangeiro (exemplo de teatro moderno e de qualidade) ou divulgavam a não-existência de um teatro nacional, constituindo uma retórica de negação que culminava com a certeza da 'morte dessa arte'. A discussão principal girava em torno do esmagamento do teatro pelo advento do cinema versus o excelente momento para a criação de um teatro verdadeiramente nacional.

O segundo grupo é composto por periódicos que não surgiram como conseqüência da Semana de Arte Moderna ou que não tiveram relação direta com o movimento. Muitos desses periódicos atravessam a década de 20 sem ao menos publicar uma única linha sobre o movimento modernista. Ao contrário do primeiro grupo, fazem parte de agremiações ou empresas especializadas que garantiam o apoio da publicidade e, conseqüentemente, produziam amplas tiragens e tinham longa duração. Geralmente classificadas como revistas de variedades, elas traziam uma vasta cobertura sobre a vida social, cultural, política e econômica da sociedade de 20 e 30.

O teatro era assunto abordado freqüentemente nas páginas dessas revistas. Por meio delas, tivemos a confirmação de que havia, sim, uma agitada vida teatral na época: diversas companhias em cartaz, produção semanal de novas peças, dramaturgia em alta, atores e atrizes de sucesso, bilheterias esgotadas, surgimento do rádio-teatro e discussões em torno do advento do cinema.

É importante ressaltar que o agrupamento delimitado acima só foi definido depois de concluído todo o levantamento de dados da pesquisa. Foram considerados não apenas a natureza do periódico analisado, mas também sua data de início e término de publicação, sua relação com os acontecimentos artísticos e culturais da época, seu tempo de circulação, e, principalmente, o modo pelo qual esses periódicos abordavam a questão teatral. Entenda- 
se que essa divisão foi estabelecida para facilitar a compreensão do nosso tema central - o teatro - e não se propõe a ir além.

Assim, tentaremos levar em conta as cisões internas de cada grupo, abrangendo as aproximações, afastamentos e transformações dos intelectuais dentro de seu grupo e entre os grupos em questão. Sabemos, por exemplo, que, apesar de fazer parte da divisão das 'outras revistas', a Revista do Brasil teve sua fase modernista; e que, apesar de fazer parte do grupo modernista, o critico Antonio de Alcântara Machado aparece na revista Ilustração Brasileira. A principal base de sustentação para a divisão desses grupos é a maneira com que cada grupo aborda a questão teatral.

Partindo então da divisão proposta acima, mostraremos de que maneira cada grupo contribuiu para a discussão sobre o teatro nacional, relacionando suas principais idéias e apontando as mais diversas propostas dos colaboradores e críticos da época. Sempre que possível, estabeleceremos um diálogo com a bibliografia já existente, de modo a apresentar uma visão ampla sobre o que foi levantado.

Entretanto, antes de prosseguir com a análise das matérias dos periódicos acima relacionados, acreditamos ser relevante nos determos por alguns instantes para compreender de que modo a censura - instrumento de regulamentação utilizado no Estado Novo - influenciou e/ou alterou características das revistas por nós pesquisadas, já que nossa data limite - 1942 - ultrapassa a data de estabelecimento do regime - 1937.

\section{A Censura nos Periódicos Analisados}

A expansão da imprensa na década de 30 reflete diretamente os fatores políticos, econômicos e culturais do país. O processo de industrialização, iniciado na Primeira Grande Guerra, a Revolução Constitucionalista, que acelera a economia do eixo Rio-São Paulo e os efeitos da Crise de 29 e da República de 30 geram substanciais transformações na organização da sociedade. E os jornais, acompanhados pelo rádio, revistas, livros e propagandas engajam-se nessas transformações. As mudanças da década de 30 contam com a participação de todo o aparato da nascente indústria cultural brasileira ${ }^{8}$.

\footnotetext{
${ }^{8}$ BAHIA, Juarez. Op.cit. p. 214.
} 
Com a implantação do Estado-Novo em 1937, diversos jornais e revistas foram fechados e um grande número de jornalistas foi preso devido à censura imposta pelo governo. O DIP (Departamento de Imprensa e Propaganda), criado em 1939, controlava a imprensa, o rádio e os assuntos a serem abordados.

A censura funcionava como instrumento moralizador colaborando para a construção de uma imagem positiva do Estado. [...] Tanto o DIP quanto o DOPS funcionavam como engrenagens reguladoras das relações entre Estado e o povo; verdadeiras máquinas de filtrar a realidade, deformando os fatos e construindo imagens ${ }^{9}$.

Apesar de ter sido mais atuante na proibição e interdição de jornais, a censura também abafou a livre expressão das revistas da época, principalmente as de cunho operário. A imprensa preocupada em conscientizar a classe como agente social circulou nas sombras da clandestinidade.

A partir do momento em que o Estado criou um órgão dedicado a reprimir idéias sediciosas, caçar a palavra e penalizar seus mentores, anulava-se a noção de sociedade civil. Os descontentes não eram reconhecidos pelo discurso oficial, de tal forma que durante os conflitos eram considerados ilegítimos e, como tais, presos e julgados por seus desvios ${ }^{10}$.

Dessa forma, circularam no negro período de 1937 a 1945, somente aqueles periódicos que não possuíam em sua natureza um caráter político, militante ou irreverente. O próprio Governo, por meio de empresas, mantinha a publicação de revistas culturais com a finalidade de distrair e divertir a população. Por exemplo, as Empresas Incorporadas ao Patrimônio da União garantiam a circulação de revistas como Carioca, de 1935 e Vamos Ler!, de 1936. Os temas abordados eram cinema, rádio, música e literatura, todos ilustrados com diversas figuras e cores e com seções dedicadas aos leitores e aos artistas.

Dentre as revistas aqui analisadas, tanto A Cena Muda (1921 a 1955) quanto a Fon Fon (1907 a 1958?) cabem na descrição acima. Repletas de fotos coloridas e chamativas e

\footnotetext{
${ }^{9}$ CARNEIRO, Maria Luiza Tucci e KOSSOY, Boris (Org.). A Imprensa Confiscada pelo DEOPS - 19241954. São Paulo: Ateliê Editorial; Imprensa Oficial do Estado de São Paulo; Arquivo do Estado: 2003. p. 47. ${ }^{10}$ Idem, p. 19.
} 
de considerações sobre a vida dos artistas e dos integrantes da alta-sociedade, elas não encontraram nenhum problema com o DIP ou o DEOPS; sua circulação atravessou os anos negros da ditadura sem perturbar a ordem do Estado-Novo.

Com o caráter bem menos popular e com uma quantidade expressivamente reduzida de ilustrações, outras publicações continuaram a circular sem grandes dificuldades. Os periódicos Boletim de Ariel (1931-1939), Revista do Brasil (1938-1943, 4ª fase), Ilustração Brasileira (1909-1953) e Revista da Academia Brasileira de Letras (1910-1973), por nós consultados, não apresentam nenhuma ocorrência de perseguição ou censura por parte do Governo.

Registramos também o surgimento de diversas publicações durante o período em questão: Dom Casmurro (RJ-1937-1946), Anuário Brasileiro de Literatura (RJ-19371944), Mensagem (BH-1941-1944) e Clima (SP-1941-1944). Apesar de abordarem temas variados, como economia, política, sociedade e artes, seus colaboradores possuíam uma regulagem interna que media a intenção das matérias: a auto-censura. Essa questão torna-se mais clara por meio do depoimento de Ruy Coelho, publicado na tese de Maria Neuma Barreto Cavalcante sobre a revista Clima:

Não tivemos uma censura tão direta como tivemos agora, uma censura férrea, mas havia conselhos. O Getúlio era um homem muito mais hábil do que esses militares que estão no poder agora. E tínhamos também uma certa auto-censura, sabendo que havia coisas. Existia uma censura pesada sobre os jornais, mas não tão grande sobre as revistas. Mas nós tínhamos elementos de ligação com o DIP, gente que nos aconselhava a disfarçar mais ou menos. Não fomos muito incomodados pela censura, era mais uma coisa de auto-censura ${ }^{11}$.

O hebdomadário Dom Casmurro trazia sempre as diretrizes do Estado-Novo e apresentava Getúlio Vargas como um político coerente e disposto a melhorar a vida econômica e cultural do país, destacando também as iniciativas de seu Ministro da Educação, Gustavo Capanema.

\footnotetext{
${ }^{11}$ CAVAlCANTE, Maria Neuma Barreto. Clima - Contribuição para o Estudo do Modernismo. São Paulo:
} 1978 (Tese Mestrado - FFLCH/USP). p. 194. 
Uma outra maneira encontrada pelo Governo para difundir seus ideais e propósitos entre a população foi a veiculação de sua própria propaganda, por meio de publicações que defendessem suas medidas e apresentassem as melhorias de sua atuação. Com efeito, o Governo publica revistas como Planalto, quinzenário paulista editado pelo DEI (Departamento Estadual de Imprensa), que circulou de 1939 a 1942; e Cultura Política, editada no Rio de Janeiro pelo DIP, sob a direção de Almir de Andrade, que circulou de 1941 a $1945^{12}$.

Esta última faz parte da relação de periódicos consultados nesta pesquisa e, por tal razão, podemos nos deter por alguns instantes para comentar a natureza dos artigos publicados. Um dos objetivos da revista era de despertar, dilatar e fortalecer a consciência política que precisava existir em todo esforço de cultura, espelhando o Brasil em todas as suas faces para testemunhar e registrar a evolução da mentalidade social brasileira. Almir de Andrade aponta em seu texto de abertura do segundo número da revista a relevância da ordem política na organização cultural de uma sociedade:

Tudo o que um povo produz pela sua cultura representa suas aspirações e necessidades de vida; a cultura é esse mesmo povo vivendo, criando obras de arte e de pensamento, costumes e tradições, formas de convivência e hábitos sociais. Mas nada disso subsiste sem a garantia de uma organização capaz de manter a paz, de conciliar interesses, de harmonizar tendências, de ajustar as necessidades de cada um às exigências de todos. $\mathrm{E}$ essa organização - que defende, que sustenta, que permite o desenvolvimento de uma coletividade através de todos os seus elementos de cultura - é a ordem política. ${ }^{13}$

Fica claro nesta passagem que o Estado, como engrenagem reguladora de todas as diferenças, controlava não apenas a veiculação de idéias, mas também qualquer produção artística e cultural do país. Tudo deveria estar de acordo com as tendências e necessidades do Governo, garantindo a manutenção da ordem política. Veremos mais adiante de que forma esses periódicos abordavam o teatro nacional e em que medida o Estado-Novo influenciava as produções e a circulação das questões teatrais.

\footnotetext{
${ }^{12}$ SODRÉ, Nelson Werneck. História da Imprensa no Brasil. $4^{\mathrm{a}}$ ed. Rio de Janeiro: Mauad, 1999. p. 384.

${ }^{13}$ ANDRADE, Almir de. Cultura Política. Rio de Janeiro: no 02, abril de 1941, p. 07.
} 


\subsection{Revistas Modernistas}

As revistas modernistas surgem como reflexo direto da Semana de Arte de Moderna. Até mais ou menos 1935, os intelectuais buscaram, nas páginas dos periódicos que criaram, consolidar as bases do projeto modernista, refletir, criticar, agitar e transformar o 'passadismo' em 'futurismo'.

Muito mais que publicações literárias, essas revistas dedicavam suas páginas a uma investigação no tempo e no espaço das manifestações cotidianas do povo, revelando um grande interesse pela formação do homem brasileiro. Essa redescoberta deveria ser apropriada pela arte, linguagem e ações; agora, a imitação estrangeira era preocupação constante, uma vez que esta poderia sufocar uma cultura nascente.

Entretanto, além do embate contra os 'passadistas', surge o embate entre os componentes do grupo inovador. As polêmicas e as divergências acentuam os desentendimentos e evoluem para uma cisão interna na geração que rompera novos caminhos culturais e artísticos ${ }^{14}$.

Maria Lúcia Fernandes Guelfi aponta em seu estudo sobre a revista Novíssima que os diversos grupos que se formaram ao longo da década de 20 sustentaram os dois ideais que os uniram no começo do movimento: a busca pela liberdade formal e a necessidade de expressar o espírito brasileiro. Entretanto, "os ideais podiam ser os mesmos; mas o modo de realizá-los era completamente diferente de um grupo para o outro"15. E essa diferença pode ser observada na maneira com que cada grupo se posiciona em relação às bases do movimento e a consolidação dos ideais de vanguarda.

Pretendemos discorrer sobre o posicionamento de cada periódico modernista face à organização do movimento e sobre a maneira com que cada um deles abordou a questão teatral em suas páginas.

\footnotetext{
${ }^{14}$ COUTINHO, Afrânio. A Literatura no Brasil. Vol 05. São Paulo: Global, 2003. p. 28.

15 GUELFI, Maria Lúcia Fernandes. Novíssima: Estética e Ideologia na Década de Vinte. São Paulo: USP/IEB, 1987. p. 136.
} 


\section{$\underline{\text { Klaxon }}$}

Primeira e principal representante do movimento modernista, a revista Klaxon surge como "um órgão de uma coletividade intelectual, de um grupo empenhado no exercício de uma linha de arte e pensamento destoante da que se praticava no País"16. Entre seus colaboradores estavam Antonio Carlos de Couto de Barros, Tácito de Almeida, Guilherme de Almeida, Mário e Oswald de Andrade, Sérgio Milliet, Luís Aranha e Rubens Borba de Moraes.

Entre as primeiras tarefas de Klaxon estava o empenho de renovar o campo da literatura, da arte e da cultura. Antes de nacionalistas, os klaxistas eram 'internacionalistas' e não queriam que o Brasil ficasse de fora - "O que desejávamos era modernizar o Brasil. Essa era a nossa luta"17. Com efeito, essa luta iniciou-se com a negação ao uso de uma língua emprestada e antiquada, que não incorporava a sintaxe brasileira, os vocabulários regionais e a forma popular. Juntamente com as novas formas, vieram os novos conteúdos, que originavam-se nas pesquisas e nas representações de tudo que era genuinamente nosso, verdadeiramente nacional.

É direta e profunda a ligação de Klaxon com a Semana de Arte Moderna, não apenas pela proximidade temporal, mas também pelo trabalho consciente dos intelectuais que a delinearam. Logo no primeiro número da revista, Mário de Andrade, em bases de um manifesto, ressalta:

Houve erros proclamados em voz alta. Pregaram-se idéias inadmissíveis. É preciso refletir. É preciso esclarecer. É preciso construir. Daí $K L A X O N^{18}$.

Os significados da Semana são vistos por um olhar crítico de quem pretende refletir, ponderar, esclarecer e construir tendências e valores em um debate conjunto que abraçasse todos os campos culturais. Assim, a ciência, as correntes artísticas, o teatro e o cinema contribuíram para os estudos, as lições e as representações klaxistas que negavam nacionalismos estreitos na sua busca pelo progresso.

\footnotetext{
${ }^{16}$ BRITO, Mário da Silva. Op. cit. s/p.

17 MORAES, Rubens Borba de. "Recordações de um Sobrevivente da Semana de Arte Moderna". In: AMARAL, Aracy A. Artes Plásticas na Semana de 22. $5^{\text {a }}$ ed. São Paulo: Editora 34, 1998. p. 301.

${ }^{18}$ KLAXON, $\mathrm{n}^{\circ} 01$, maio/1922.
} 
Com o olhar direcionado para o futuro, Klaxon se omite quase que totalmente em relação à produção teatral da época. Fica claro em seu manifesto que o teatro é a arte do passado que não encontrará espaços para florescer no século XX. Por outro lado, o cinema ganha foco e representatividade nas páginas da revista:

KLAXON sabe que o cinematógrafo existe. Pérola White é preferível a Sarah Bernhardt. Sarah é tragédia, romantismo sentimental e técnico. Pérola é raciocínio, instrução, esporte, rapidez, alegria, vida. Sarah Bernhardt = século 19. Pérola White = século 20. A cinematografia é a criação artística mais representativa da nossa época. É preciso observar-lhe a lição ${ }^{19}$.

Mesmo com a lacuna de matérias sobre a vida teatral da época, localizamos em Klaxon um relato de Roger Avermaete (1.3.1.1.) sobre uma experiência feita na Bélgica com teatro de bonecos. "O relato comprova o cultivo de um espírito de pesquisa em todos os setores da arte, com a associação estreita de arte e técnica, para renovar em profundidade qualquer campo",20.

Iná Camargo Costa, em seu estudo intitulado Dramaturgia Modernista em 22 aponta que havia uma patologia, desde os tempos de Machado de Assis, que originou um abismo total entre dramaturgos e literatos que reclamavam do desaparecimento da 'dramaturgia séria'. O resultado desse distanciamento foi o seguinte:

... em 1922, a distância entre o teatro realmente existente e os escritores que fizeram a Semana de Arte Moderna era tal que se algum deles tivesse escrito ou em mente algum texto para teatro, talvez nem soubesse a quem arregimentar para fins de encenação ${ }^{21}$.

Isso reforça o argumento que sustenta que a modernização do teatro brasileiro só seria possível se todas as esferas da composição teatral (dramaturgia, ator, encenação, direção, público e crítica) estivessem alinhadas com mesmo propósito. Isoladamente, a dramaturgia

\footnotetext{
${ }^{19}$ KLAXON, n. 01, maio/1922.

${ }^{20}$ LARA, Cecília de. Klaxon \& Terra Roxa e Outras Terras: Dois Periódicos Modernistas. São Paulo: IEB, 1972.p. 94.

${ }^{21}$ COSTA, Iná Camargo "Dramaturgia Modernista em 22". Literatura e Sociedade. no 7. São Paulo: USP/FFLCH/DTLLC, 2003/2004. s/p.
} 
ou a crítica pouco conseguiriam. Com efeito, acreditamos ser por essa razão que o fragmento dramático escrito por Sérgio Buarque de Hollanda, publicado no quarto número de Klaxon, pouco tenha significado para a história do teatro brasileiro. Entretanto, o fragmento, intitulado Antinous (1.1.1), apresenta características modernas e interessantes para a dramaturgia.

Além de estabelecer um diálogo com os gêneros teatrais em voga na época (teatro de revista e a comédia de costumes), o fragmento aborda a euforia carioca com o recente processo de modernização do Rio de Janeiro, demonstrando o estabelecimento de um olhar crítico sobre as práticas sociais e desiguais e sobre o deslumbramento com os aspectos exteriores da modernidade por meio de clichês já há muito consolidados em nossos palcos. Isso pode ser observado pelas palavras do orador, quando da recepção do Imperador Adriano:

Sim senhores, o Imperador arquiteto. O imperador artista. Vede esta cidade monstro com seus edifícios, seus arranha-céus, com suas ruas asfaltadas, com seus anúncios, com seus cinemas, seus cartazes...Vede este palácio...(Aponta para um palácio que tem o aspecto de um formidável queijo de Minas). Vede a civilização borborinhante que enche as nossas ruas, as nossas praças, os nossos boulevards, os nossos... Vede tudo o que nos cerca. Tudo, tudo obra de um só homem. De um só cérebro.

Assim, salvo esses dois pontuais momentos reservados à temática teatral, Klaxon avança seu olhar sobre as inovações do século XX, apostando nos válidos ensinamentos da arte cinematográfica. Sua contribuição ao teatro é mínima, passando muitas vezes despercebida.

\section{$\underline{\text { Estética }}$}

Fundamentalmente literária e dirigida por Prudente de Moraes Neto e Sérgio Buarque de Holanda, a Estética surge no Rio de Janeiro com a intenção de ponderar e criar a partir dos manifestos da fase heróica do modernismo. Agora, com um certo distanciamento temporal, a tentativa era de retomar os motivos modernistas a partir da organização e estruturação de um olhar crítico. Sérgio Buarque de Hollanda afirma que: 
A Klaxon tinha sido uma revista que rompia com uma porção de coisas. Precisava-se fazer uma revista que passasse a construir alguma coisa a partir daquela ruptura, com a mesma gente e gente que foi aparecendo depois, porque muitos não estavam na Semana de Arte Moderna ${ }^{22}$.

Apesar de apresentar uma forma conservadora e uma tipografia discreta, foi nas páginas de revista Estética que Prudente de Moraes Neto iniciaria as bases de sua reputação como crítico. O foco dos colaboradores era outro - aventurar-se no campo da esfera literária tornou-se o objetivo dos escritores modernistas da revista.

De tiragem reduzida e periodicidade irregular, Estética durou apenas três números: $\mathrm{n}^{\circ}$ 01 de set/1924, no 02 de jan a mar/ 1925 e o no 03 de abr a jun/1925. Sua contribuição à temática teatral, assim como Klaxon, é reduzida. Destacamos apenas a peça Moral Quotidiana, de Mário de Andrade (3.1.1.), que viria a ser publicada posteriormente em seu livro Primeiro Andar ${ }^{23}$.

Da mesma maneira que Antinuos, de Sérgio Buarque de Hollanda, Moral Quotidiana traz em sua organização elementos de uma dramaturgia moderna, ao ir além dos fatos e abarcar um olhar crítico e bem-humorado dos clichês existentes nas peças da época. Apesar do autor indicar que se trata de uma tragédia, a demolição do clichê e das inversões do previsível dá um tom bem acentuado de comédia que permeia toda a peça. Um jovem casal defronta-se com a ex-amante do marido e a presença de quatro coros representantes da sociedade propiciam a discussão dos costumes de pessoas da alta classe e dos valores de uma sociedade machista e conservadora. Surpreendentemente, a discussão evolui para a defesa da amante em oposição à esposa.

Mário de Andrade anuncia que sua peça tem apenas um ato, o terceiro. Isso nos leva a questionar o porquê da eliminação do primeiro e do segundo ato. Iná Camargo Costa nos apresenta duas hipóteses: 1. para se enquadrar ao sistema das empresas teatrais que mutilam peças de três horas para fazê-las caber em sessões de 1 hora e meia, garantindo até três apresentações diárias e mantendo justa a concorrência com o cinema; 2. para criticar indiretamente a estrutura da peça bem feita em que os dois primeiros atos apenas enrolam o

\footnotetext{
${ }^{22}$ HOLLANDA, Sérgio Buarque de. Entrevista. In: LEONEL, M. C. de M. Revista Estética. Dissertação de Mestrado. São Paulo: FFLCH/USP, 1976. p. 229.

${ }^{23}$ ANDRADE, Mário de. Primeiro Andar. São Paulo: Antonio Tisi, 1926.
} 
espectador para chegar ao que interessa, o terceiro ato. Independente da intenção da crítica implícita, ele foi direto ao ponto.

Ambas as peças apresentadas acima só poderiam ter sido publicadas nas revistas de teor moderno, cujos colaboradores e diretores abarcassem o mesmo sentimento crítico e vanguardista de Sérgio Buarque e Mário de Andrade. Propostas dramatúrgicas como estas precisavam, sim, de um veículo de trincheira para vir a público.

\section{$\underline{\text { A Revista }}$}

Seguindo os passos de Klaxon, A Revista surge com o grupo de intelectuais de Belo Horizonte interessado em dar voz e volume ao movimento. Sob a direção de Martins de Almeida e Carlos Drummond de Andrade, a revista circulou de 1925 a 1926. A opção nacionalista defendida no manifesto da revista revela que uma nova fase permeia a geração modernista:

A confissão desse nacionalismo constitui o maior orgulho de nossa geração, que não pratica a xenofobia, nem o chauvinismo, e que longe de repudiar as correntes civilizadoras da Europa tenta, intenta submeter o Brasil cada vez mais ao seu influxo, sem quebra de nossa originalidade nacional. ${ }^{24}$

Foi nas páginas dessa revista que encontramos o depoimento-manifesto de Magalhães Drummond, intitulado Momento Brasileiro II (4.3.2.1). Bem menos eufórico que os colaboradores de Klaxon, o grupo d'A Revista reconhece o brasileirismo orgânico, intrínseco e estrutural que permeava a nossa literatura: "é o retrato, a água forte, do brasileiro em sua atual sedimentação étnica, é a projeção da mentalidade do brasileiro, tal qual a deixou formada o caldeamento de raças, em transfusões e permutas seculares".

Representando os ideais defendidos pela revista, o autor apresenta sua posição em relação aos outros grupos de combate modernista, exemplificando os afastamentos e aproximações que passavam a assombrar a geração de 22:

Há na arte dos Guilherme de Almeida, dos Mário de Andrade e do grupo juvenil d'Estética, principalmente esse grito instintivo, irreprimível, de almas felizes por se

${ }^{24}$ A Revista. Manifesto, $\mathrm{n}^{\circ}$ 01, p. 02. 
sentirem em harmonia com os seus patrícios do seu tempo. Há quem combata a chamada 'escola paulista' e a toda nova corrente, e há mesmo quem vaticine vida efêmera. Eu, ao contrário, creio que ela vai durar, e penso que dela passarão apenas os exageros de técnica. Dela caducará somente o que haja de artificioso. Mas, na sua essência e nas suas intenções fundamentais ela ficará, porque, enquanto a isso, se enraíza em algo muito estável e que é a constituição íntima da psyché nacional e porque procura servir algo de muito real, ou seja, as aspirações e anseios do Brasil atual (4.3.2.1).

Contrariamente aos dois periódicos apresentados anteriormente, A Revista abre espaço em suas páginas para discorrer sobre a situação do teatro nacional, reconhecendo talentos e apontando para a importância de se representar o espírito brasileiro nos nossos palcos.

No teatro, os trabalhos de Renato Vianna, de Carlos Góes, de Oduvaldo, de Abadie, de Alberto Deodato, de Pujol e de tantos e tantos outros aí estão projetando para a luz da ribalta, em excelentes afirmações vitoriosas, esse mesmo espírito brasileiro de agora para o qual o assunto em foco é o assunto brasileiro, a vida brasileira, tal qual a estamos vivendo, uniforme nos seus objetivos e ao ritmo do mais íntimo e mais essencial metabolismo, embora, com as diferenças externas em que nela se refletem os matizes propriamente locais (4.3.2.1).

É curioso observar que dentre os periódicos modernistas, A Revista foi o único a considerar as realizações do teatro nacional daquela época como válidas e importantes para o desenvolvimento de uma manifestação artística que se iguale à pintura, à música, à caricatura e à literatura.

\section{Novíssima}

Antes de prosseguirmos com os desdobramentos da geração modernista ao longo da década de 20, deteremos nosso olhar por alguns instantes na contribuição de uma revista que surgiu logo após Klaxon na imprensa periódica de São Paulo, em 1923. Faz parte do grupo modernista por apresentar ideais semelhantes aos defendidos pelo grupo vanguardista, mas se afastou da postura radical adotada por alguns de seus integrantes. 
A revista abre espaço para a contribuição de modernistas como Oswald de Andrade, mas deixa transparecer sua não-aceitação dos radicalismos da renovação. Participa da dinâmica do Modernismo enquanto movimento nacionalista.

Novíssima assumiu, portanto, postura própria, em relação ao grupo renovador, pois manteve-se presa a uma linha presente na raiz da modernização como um dos veios que Klaxon canalizou, e do qual logo mais se desviaram os modernistas mais radicais. Em Novíssima, trata-se, de início, de atitude ante a arte e a literatura, na defesa de conceitos clássicos de beleza, como algo ideal, imutável no tempo e no espaço ${ }^{25}$.

É possível observar no manifesto da revista Novíssima que, apesar do título, ela não será destruidora do passado e da tradição, mas sim, defensora dos novos valores sempre à luz da "sabedoria dos milênios e do prestígio da eternidade". Além disso, a revista não se posiciona contra ou favor de nenhuma corrente literária e nem seleciona capacidades:

Não abomina nenhuma escola, em assuntos de arte ou literatura; não faz seleção de capacidades, entre o maior e o menor, entre o mais novo e o mais velho, entre os deste e os daquele grupo. Basta-lhe o cunho da inteligência; seja nos laivos de ouro antigo, seja na iluminada estesia do instante que passa. De uma coisa, neste particular, é que NOVÍSSIMA se faz servidora: é da Beleza, que é o fito da arte, sejam quais forem as fórmulas, e os seus meios de expressão ${ }^{26}$.

Maria Lúcia Guelfi afirma que, não podendo ficar alheia ao Movimento Modernista, Novíssima resolvera aderir por uma via menos radical, filiando-se ao "classicismo moderno", movimento de renovação que surgiu na França, que defende a existência de correntes reformadoras orientadas por um ideal perfeitamente lógico e não-radical. Dessa forma, o grupo de Novíssima defende a multiplicidade de novas tendências, amparadas pelo "talento" (que coloca os espíritos acima das divergências) e pelo "ideal de Beleza" (objeto universal de toda arte), critérios propiciadores da harmonia entre as concepções estéticas da renovação.

\footnotetext{
${ }^{25}$ LARA, Cecilia de. Prefacio. GUELFI, M. L. F. Novíssima: Estética e Ideologia na Década de Vinte. São Paulo: IEB/USP, 1987. p. 09.

${ }^{26}$ GUELFI, M.L.F. Op. cit. p. 226.
} 
Em relação à temática teatral, os artigos encontrados em Novíssima diferem dos publicados nos demais periódicos modernistas tanto na quantidade quanto no conteúdo. Considerando os poucos números da revista, o teatro obteve destaque, aparecendo em diversas notas, artigos e entrevistas.

Por não possuir uma postura mais extremada, os artigos publicados não apresentam aquele aspecto reivindicatório de um teatro verdadeiramente nacional citado acima. Novíssima não apenas valorizava o teatro da época, receptor de influências estrangeiras e promovedor das comédias de costumes, mas também incentivava a produção das companhias em cartaz, apelando para o bom gosto da elite social. As temporadas da Companhia Procópio Ferreira no Teatro Royal são as de maior destaque entre as matérias publicadas. Artigos que exaltam o talento dos artistas e fotos dos integrantes da companhia reforçam a intenção primeira da revista em incentivar os empreendimentos de Procópio Ferreira.

Novíssima também apóia iniciativas menores, como o aparecimento de uma nova companhia de comédias, intitulada Colméia, fundada por Renato Vianna e Simões Coelho. No artigo "Criando o Teatro Brasileiro" (2.4.2), Benjamin de Garay aplaude a iniciativa e aponta para o caráter coletivo da companhia iniciante, contra os princípios de 'estrelas' e figuras isoladas, sendo por isso, uma obra de combate.

Destacam-se também na revista os anúncios da Companhia Italiana de E. Zacconi, por meio de fotos, entrevistas e artigos, como o escrito por Procópio Ferreira, "Diante dele estou de joelhos" (2.3.4.1), no qual o autor declara sua enorme admiração pelo talentoso ator italiano.

O único artigo que destoa da natureza dos demais é o escrito por Antonio de Alcântara Machado, intitulado "O que eu disse a um comediógrafo nacional” (2.3.2.2), no qual o autor, por meio de um diálogo imaginário, critica a forma de se fazer teatro no Brasil e aponta a ausência de temas nacionais nos nossos palcos. Segundo o autor:

Na literatura dramática nacional há 3 tipos de comédias: o tipo piegas ou Flores de Sombra; o tipo caricatural ou O Simpático Jeremias e o tipo A Vida é um Sonho... que é da comédia de costumes. 
Nenhuma delas representa de fato a realidade do nosso povo, da nossa terra. Para Machado, o comediógrafo nacional deve perder o vício de representar o estrangeiro através de situações repetidas. Suas palavras ecoam como as de um protesto:

Abrasileiremos o teatro brasileiro. Melhor: apaulistanisemo-lo. Fixemos no palco o instante radioso de febre e de esforço que vivemos. [...] Há a importar as fórmulas, tão somente as fórmulas. As de hoje, as deste tempo, as fórmulas inovadoras e moças de Romains, de Shaw, de Pirandello, de Zimmer, de Tchapek, de Gontillon, de tantos, de tantos! Vamos! Um bocadinho de coragem e de mocidade!

Podemos assim perceber que Novíssima não defende uma única posição em relação à situação do teatro nacional; ela abrange as visões tradicionalistas de quem defendia a produção nacional de comédias de costumes e as visões vanguardistas de quem buscava a modernidade no texto e na concepção do espetáculo.

\section{Terra Roxa e Outras Terras}

Este pequeno jornal literário apresentou durante o ano de 1926 sete números com uma periodicidade irregular. Seguindo uma linha que já vinha sendo delineada por A Revista, Terra Roxa e Outras Terras se apóia nos mesmos pilares que marcarão a geração modernista pós 1925. A clara opção nacionalista e o repúdio ao estrangeiro e ao imigrante como ameaças à cultura nascente balizam e sustentam o manifesto desses grupos.

O comum é tomar o brasileirismo dos temas e da linguagem como objeto de consideração nas obras. Mas isso não significa que se excluam as preocupações de caráter estético. Mas é o brasileirismo que se erige em critério de avaliação das obras, como antes acontecia com o caráter modernista ou passadista dos mesmos. ${ }^{27}$

Passada a euforia da Semana, o intento agora é revisar as atitudes e os procedimentos literários, sustentando a busca pela 'cor local', sustentada pela nossa história, língua e tradição. Essa busca pelo nacional será evidenciada na principal expressão modernista em

\footnotetext{
${ }^{27}$ LARA, Cecília de. Terra Roxa... e Outras Terras, um Periódico Pau Brasil. Introdução da edição fac-
} similada da revista Terra Roxa e Outras Terras. São Paulo: Livraria Martins, 1977. 
relação à crítica teatral de nosso país. Antônio de Alcântara Machado destaca-se como o único combatente modernista a enfatizar de modo significativo a "miséria do teatro brasileiro" e a apontar caminhos para a modernização dessa arte. Em artigos como 'Indesejáveis"; "Rir, chorar ou dar?"; "Questão de Vergonha”; e "Assim é que é” (5.3.2), o autor revela sua preocupação com a imitação e a valorização do estrangeiro, com a repetição de repertório, com a baixa qualidade dos dramaturgos e atores nacionais e com os altos preços dos ingressos. Retomaremos as principais idéias de Alcântara Machado no capítulo 3, dedicado às contribuições da crítica teatral para a manutenção do teatro nacional.

\section{Festa}

Festa: Mensário de Arte e Pensamento circulou no Rio de Janeiro de 1927 a 1928 e, depois de um intervalo, retornou em 1934 e perdurou até 1935, totalizando 22 números. Sob a direção de Tasso da Silveira, Andrade Murici e do 'Grupo Festa', a revista foi criada na intenção de se consolidar os valores modernistas em terras cariocas e ao mesmo tempo combater os modernistas de São Paulo:

Basta escrever em língua pau-brasil, dizer graças ou imitar o balbucio das crianças para estar na corrente. Isso no começo escandalizou ou pareceu interessante a muita gente. Mas já deu o que tinha que dar. Vai morrendo em ondas epígonas lá para os confins de São Paulo ou de Minas... ${ }^{28}$

A publicação, seguindo a linha dos outros periódicos desse grupo, apresenta um único texto sobre teatro: "Teatro Brasileiro", de Walter Benevides (6.3.2.1). Dando continuidade à retórica da negação presente no posicionamento modernista frente à produção teatral da época, o autor afirma que:

O teatro brasileiro continua não existindo. Mas justamente por isso é que eu acho a sua situação maravilhosa. Que campo esplêndido para o treinamento livre das faculdades criadoras... Sim. A sua situação é esplêndida por isso. Nos outros gêneros literários já nós estamos habituados de há muito. Mas no teatro, nem nada. Ocasião ótima, portanto,

\footnotetext{
${ }^{28}$ Festa, no 01 , out/1927.
} 
para o nosso modernismo se apresentar em toda a plenitude, trabalhando em mata virgem. [...] O que por ele se fizer há de ser coisa nova, inteiramente nova, e, portanto, nossa. Do contrário é inútil.

É possível destacar, a partir das considerações acima, que o discurso dos colaboradores de Festa, que ecoa as vozes modernistas da época, ignora a produção teatral em voga nos anos 20 e 30. As peças representadas e as companhias em cartaz não possuíam nenhum valor artístico para os intelectuais modernistas, que apontavam sempre a necessidade de se criar algo novo, verdadeiramente nacional, sem imitações ou importações que comprometessem os princípios nacionais. Criticava-se a ausência de dramaturgos nacionais capacitados para representar a 'cor local' e de artistas que explorassem os elementos do cotidiano para a criação de um teatro inédito e livre.

\section{$\underline{\text { Verde }}$}

Em 1927, na cidade mineira de Cataguazes, um grupo dirigido por Henrique de Rezende cria a revista Verde com a intenção de lutar pela implantação das novas idéias estéticas já em ação nos grandes centros do país. Adotaram uma linha nativista, destacando o cotidiano num nacionalismo bem definido. Declaram em seu manifesto que: "Abrasileirar o Brasil - é o nosso risco. Pra isso é que a VERDE nasceu. Por isso é que a $V E R D E$ vai viver. E por isso, ainda, é que a VERDE vai morrer" ${ }^{29}$.

A única contribuição em relação ao teatro é um longo artigo sobre a originalidade das obras de Luigi Pirandello que representam a completa desarticulação do homem e retratam a 'falência do super-homem no século XX' (7.3.4.1). Tristão de Ataíde faz um balanço das contribuições à arte moderna, comparando Pirandello a grandes nomes da literatura moderna, como James Joyce, Virginia Wolf e Bernard Shaw.

Publicado na seção 'Feira de Amostras', esse artigo abre uma janela sobre a produção literária e teatral estrangeira na tentativa de representar os frutos da arte moderna em grandes centros culturais e intelectuais do mundo.

\footnotetext{
${ }^{29}$ Verde. Manifesto. № $01,1927$.
} 


\section{$\underline{\text { Revista de Antropofagia }}$}

Deslumbrado com a significação do quadro Abaporu, pintado por Tarsila do Amaral, Oswald de Andrade e Raul Bopp se unem na tentativa de criar um movimento que contivesse a idéia da terra, do homem nativo, selvagem, antropófago. A Revista de Antropofagia surge em 1928, com Antonio de Alcântara Machado expondo a proposta do movimento no texto Abre-Alas do primeiro número da revista:

A experiência moderna (antes: contra os outros; depois: contra os outros e contra nós mesmos) acabou despertando em cada conviva o apetite de meter o garfo no vizinho. Já começou a cardeal mastigação. [...] Todas as oposições se enfrentarão. Até 1923 havia aliados que eram inimigos. Hoje há inimigos que são aliados. A diferença é enorme. Milagres do canibalismo. ${ }^{30}$

Conhecido como o mais radical dos movimentos artísticos modernos, o grupo antropofágico insurge-se contra a descaracterização e a diluição da revolução modernista; “condenando 'a falsa cultura e a falsa moral do ocidente', os antropófagos investem contra os espiritualistas, os metafísicos, e os nacionalistas de inspiração fascista, mas recusam também os extremismos da esquerda canônica" 31 .

Sua relação com o teatro pode ser observada em dois momentos: na primeira fase da revista com uma resenha escrita por Alcântara Machado sobre o livro Estudos de Tristão de Ataíde (8.2.2.1), no qual ele discorre sobre a obra de Pirandello; e na segunda fase com a publicação de uma entrevista com Álvaro Moreyra, intitulada A propósito do teatro semnome (8.4.1). Recortamos deste último a proposta do teatro sem-nome:

Oswald de Andrade voltou da cultura para o Brasil. Álvaro partiu do Brasil para a cultura. E daí o antagonismo absoluto entre o Teatro Sem Nome, de Álvaro e a Poesia Pau Brasil de Oswald. Pau Brasil é a revelação dos encantos nativos da terra. O Teatro Sem Nome é a seleção dos materiais a serem deglutidos. A antropofagia, estabelecendo os princípios da assimilação das qualidades, abriu uma espécie de cotovelos de estrada.

Nele se encontraram o Teatro Sem Nome (que é o novo) e a Poesia Pau Brasil (que é o

\footnotetext{
${ }^{30}$ MACHADO, Antônio de Alcântara. "Abre-Alas”. Revista de Antropofagia. no 01, 1928, p. 01.

31 CAMPOS, Augusto de. "Revistas Re-vistas: os Antropófagos". Introdução da edição fac-similada da Revista de Antropofagia. São Paulo, 1976.
} 
nosso). Porque o movimento concebido por Oswald de Andrade, literariamente, é um movimento duplo. A fusão espontânea do inteiramente novo e do inteiramente nacional. O Teatro Sem Nome é uma fase de antropofagia. A primeira. Virá depois o teatro Pau Brasil. Da reunião de ambos nascerá o Teatro Antropofágico. Naturalmente. Sem se querer. Aliás, esse desejo de espírito natural identifica plenamente Álvaro Moreyra na antropofagia. Ninguém mais do que ele é namorado da brasilidade. Do ingênuo. Do gostoso. Do genuinamente nacional. E a sua derradeira feição literária o comprova.

A reivindicação de um teatro verdadeiramente nacional encerra agora uma visão que vai além da identificação e apropriação dos moldes estrangeiros. A deglutição da ordem, do método e da disciplina dá espaço ao instinto que deve prevalecer sobre todas as coisas.

\section{$\underline{\text { Movimento Brasileiro }}$}

Dando seqüência à produção de periódicos na imprensa carioca, surge em oposição à revista Festa, a publicação Movimento Brasileiro, inicialmente chamada Movimento. Inicia sua circulação em 1928 sob a idealização de Renato Almeida e Graça Aranha.

A abordagem da matéria teatral publicada na revista reflete o conceito que o grupo possuía em relação ao Movimento Modernista. Para Renato Almeida, diretor da revista, o Modernismo define-se como um movimento geral, amplo, que abrange todos os setores artísticos e todas as áreas de conhecimento e da cultura. O ponto em comum com os outros periódicos modernistas é a preocupação com o caráter de brasilidade e a necessidade de se pensar sobre a nossa história e realidade. Entretanto, o ideal da revista afasta-se dos demais ao propor uma apropriação mais sistemática da produção estrangeira moderna:

Ao contrário de Festa, e do grupo Anta, Movimento Brasileiro não recusa as influências estrangeiras, mas acredita que em qualquer ramo da atividade social, política ou intelectual, a missão brasileira será a de incorporar ao seu patrimônio a cultura universal para adaptá-la dentro da expressão peculiar de seu caráter ${ }^{32}$.

\footnotetext{
32 BOAVENTURA, Maria Eugênia. Movimento Brasileiro: Contribuição ao Estudo do Modernismo. São Paulo: FFFLCH/USP - Dissertação de Mestrado, 1974. p. 25.
} 
E será dessa maneira que a revista se posicionará em relação ao teatro, dando grande destaque às produções, às publicações e às companhias estrangeiras. Movimento Brasileiro constitui-se, entre os periódicos aqui analisados, como a referência do teatro mundial no periodismo da época. A revista publicava não apenas notícias sobre a produção teatral internacional, mas também veiculava discussões relevantes sobre a evolução do teatro moderno e as iniciativas dos principais nomes do teatro americano, japonês e europeu.

Por meio das notas dispersas nas páginas da revista, é possível identificar as principais peças e autores que estavam em foco nos palcos estrangeiros. Bernstein, LugnéPoe, Lenormand e Marcel Pagnol são referências constantes de sucesso no teatro francês. Lugné-Poe é o representante francês mais citado nas notas teatrais. São registrados seu afastamento da direção do Teatro de L'Oeuvre e sua possível vinda ao Brasil, em companhia de Suzanne Desprès, no ano de 1930.

As notas sobre as estações dramáticas do teatro alemão são importantes registros das peças levadas à cena em Berlim, Hamburgo e Viena. Os autores de maior destaque são Hasenclever com as peças $O$ Filho e Fazem-se Casamentos no Céu; Buckner com Os Criminosos; e Klabund com $X Y Z$.

Em relação ao desenvolvimento do teatro moderno europeu, as principais contribuições publicadas são o depoimento do romancista e dramaturgo austríaco Stefan Zweig e um artigo sem indicação de autoria sobre a implantação do Teatro Flutuante Alemão. O primeiro aponta a renovação pela qual o teatro europeu estava passando, devido à concorrência com o cinema e à maior exigência do público, cada vez mais sensível e impaciente em relação à idéia do tempo. Segundo o autor, as peças deveriam ser em quadros, pois ninguém suporta mais peças infindáveis e sem ação. Stefan Zweig afirma também que as invenções mecânicas possuem um valor extraordinário na concepção do teatro moderno e que só com elas os dramaturgos e atores conseguem expressar-se por meios nunca antes imaginados.

Já o artigo sobre o Teatro Flutuante Alemão descreve o ousado empreendimento em organizar em um teatro dentro de um navio para promover a dramaturgia moderna alemã (10.3.1.5): 
Os alemães resolveram organizar um teatro flutuante, destinado a percorrer a maior parte dos países do mundo, representando as obras primas da cena alemã. Um navio especial, Pro-Arte, será adaptado, com instalações modernas e uma platéia de cerca de 500 lugares. Haverá camarins, salões de leitura e uma exposição permanente de obras de arte. O repertório constará, não só de obras de Goethe, Schiller e outras peças clássicas, como de várias modernas, de sorte que os espetáculos dêem uma idéia exata da cultura alemã.

O teatro japonês ganha espaço nos artigos sobre a evolução do gênero teatral japonês, desde as produções mais tradicionais do Nô, Kjôgeu e do Jôrouri até a representação das modernas peças de Okamato Kido e sua curiosidade exótica dos dramas, cenários, figurinos e intérpretes.

O artigo intitulado "O Teatro Japonês" (10.3.1.7) faz um panorama da tradição teatral japonesa, destacando as contribuições de Tchikamatsou, no início do século XVII, com a criação do teatro de marionetes, "expressão suprema da literatura japonesa". O autor deixou 104 peças do gênero: "são pequenos romances em que um diálogo vivo, colorido, cheio de imagens, de sentimentos violentos e de detalhes familiares que, sem perder a nobreza do recitativo, imprimem uma certa grandeza legendária". No mesmo artigo, o autor discorre sobre as características modernas do teatro de Okamato Kido, que apesar de utilizar a concepção e a construção do tradicional kabouké, faz uso de um narrador "que intervém no curso do diálogo para desenvolver os pensamentos dos atores ou para sustentar sua mímica de um comentário lírico". Suas peças aqui destacadas são Duplo suicídio de Toribeyama, História Shuzeuji e Prisão de Cristãos.

Bernard Shaw aparece como principal representante do teatro inglês, com diversas notas sobre a representação de suas peças nos palcos de Berlim, Hamburgo e Varsóvia. Destaque para $O$ Kaiser da América e The Apple Cart. O teatro americano entra em cena com Eugene O'Neill e uma resenha de sua peça Strange Interlude, que foi representada pela primeira vez no Teatro Guild de Nova York.

Os italianos Pirandello e Anton Giulio Bragaglia encerram a lista dos principais nomes do teatro moderno estrangeiro notificada por Movimento Brasileiro. Em torno do primeiro autor, publica-se uma polêmica sobre a peça Seis Personagens em Busca de um Autor, que teria sido plagiada de uma novela de F. Ansley, intitulada Por que renunciei a 
escrever romances e escrita há 20 anos. O responsável pela polêmica é Paul Achar que, nas páginas da Commoedia, escreve (10.3.5.1):

\begin{abstract}
Na novela de F. Ansley, encontramos um autor que, um belo dia, vê chegar a sua casa os personagens de um dos seus livros; instalam-se ali decididamente. Querem viver na realidade as suas vidas; proclamam o direito de tudo que é criado pela imaginação de um escritor, se evadir das linhas, para desenvolver-se e ir até o fim do pensamento do seu criador.
\end{abstract}

Apesar de registrar o possível plágio, o autor não deixa de apontar o alto valor literário da peça para a dramaturgia moderna. Uma outra referência feita a Pirandello aparece no texto "Uma sátira contra o teatro de Pirandello" (10.2.2.2), que notifica a representação da peça $O$ espectador ou a quarta realidade, do escritor argentino Enrique de Rosas, em Madrid. O autor satiriza a noção de realidade da vida e do teatro abordada pelo dramaturgo italiano, na tentativa de confundir suas criações inovadoras com traços de loucura.

Já as idéias de Bragaglia aparecem na reprodução de uma conferência realizada em São Paulo e no Rio de Janeiro, na qual o diretor revela sua insatisfação com o público que não mais se sensibiliza com o teatro, apenas com o cinema. Há também uma referência a uma importante iniciativa do diretor italiano em organizar um grupo de teatro argentino independente e moderno, apostando na vivacidade do jovem ator e nas contribuições de novas técnicas para a constituição cênica do espetáculo.

Podemos então constatar que havia sim, no Brasil, a circulação de idéias a respeito do teatro moderno estrangeiro. Tanto as peças de caráter moderno quanto as inovadoras concepções cênicas e textuais obtiveram destaque nas páginas de Movimento Brasileiro.

Curiosamente, o teatro brasileiro é posto de lado, aparecendo apenas em dois registros ao longo do período pesquisado. O primeiro é uma crítica à Academia Brasileira de Letras, que manifestou apenas um apoio verbal à iniciativa do "Teatro da Gente Nova" (10.3.2.1) e nenhuma subvenção financeira para seus organizadores. $\mathrm{O}$ segundo, e mais importante registro, é o artigo "Teatro no Brasil", de Antônio de Alcântara Machado (9.3.2.1), publicado na primeira fase da revista quando ainda se chamava Movimento. O autor retoma mais uma vez a excelente ocasião para se criar o verdadeiro teatro moderno nacional e 
critica severamente a influência francesa que desde há tempos "vem estragando a cena desta terra". Além disso, Machado ironicamente aponta para a existência de diversos elementos nacionais, que misturados com a teatralidade, universalidade e mestiçagem encontradas no Brasil, gerariam legítimas obras-primas nacionais; e encerra com um pedido à geração modernista que pouco fez pelo teatro nacional.

Salvo esse importante artigo de Antônio de Alcântara Machado, podemos afirmar que a contribuição da revista Movimento Brasileiro resume-se na publicação, reflexão e discussão de toda a produção teatral, moderna ou não, na tentativa de assimilar a cultura estrangeira na expressão daquilo que há de mais nacional. Para os colaboradores da revista certamente nada do que estava sendo apresentado na vida teatral de nosso país podia ser considerado como 'expressão peculiar de nosso caráter'. Ainda tínhamos que incorporar as iniciativas dos artistas estrangeiros.

\section{$\underline{\text { Revista Nova }}$}

Lançada em 1931 sob a direção de Paulo Prado, Mário de Andrade e Antônio de Alcântara Machado, a Revista Nova dedicou-se à crítica e aos estudos que abordassem a questão da brasilidade. Inicia-se agora uma nova fase do movimento modernista, na qual a revisão do movimento e o estabelecimento das novas bases do modernismo eram a proposta principal. Recorreremos às palavras de Carlos Drummond de Andrade para entender melhor a natureza da revista:

Considero a Revista Nova um prolongamento de Klaxon, Terra Roxa \& Outras Terras e Revista de Antropofagia ( $1^{\text {a }}$ fase). Sem o vanguardismo da primeira e a relativa gratuidade da terceira, com alguma coisa do espírito da segunda, em grau evoluído. Há um certo equilíbrio e maturação de idéias. A revista comemora o centenário de Álvares de Azevedo e acolhe o pensamento marxista de Astrojildo Pereira. O artigo de apresentação acentua o sentido polêmico, a abertura e o desejo de atualização da Revista Nova. Com esse feitio, durou 8 números. Até durou demais ${ }^{33}$.

\footnotetext{
${ }^{33}$ ANDRADE, Carlos Drummond de. Entrevista. Publicada na tese de KREINZ, Glória Aparecida Rodrigues. Revista Nova. São Paulo - 1979. p. 181
} 
Assim como outros periódicos do grupo modernista, a Revista Nova apresenta uma tímida publicação sobre o teatro, da qual destacamos apenas a crítica de Alcântara Machado ao domínio de Leopoldo Froes em nossos palcos (11.3.4.1). Segundo o autor:

Antes de tudo é preciso reconhecer que Froes se beneficiará (como beneficiou em vida) da absoluta miserabilidade do teatro brasileiro. Num país onde não existe literatura dramática o ator ganha uma importância excessiva. Quero dizer: fica importante por exclusão. [...] Seu triunfo no palco nacional ele deveu antes de mais nada a sua origem e ao seu título de bacharel. Acabou com a tradição do ator pobre diabo, vindo não se sabe de onde, vivendo não se sabe como. Era o doutor Leopoldo Froes membro de uma família conhecida. Distinguível de longe entre os zé-ninguém do teatro brasileiro. [...] Depois, o senso comercial apuradíssimo. Diante dele a ganância dos empresários entregava os pontos logo de início. Froes sabia ganhar e o que ganhava guardava. Para maior garantia fez-se empresário ou sócio de empresários. Tendo a habilidade de não empregar no teatro o capital que formou com os lucros que o palco lhe deu.

Com pesadas acusações à inanição do grande ator, Alcântara Machado depõe contra a ausência de ações que Froes poderia ter tomado frente à miserabilidade do nosso teatro. Nenhum investimento, nenhuma inovação; o importante era manter o mesmo padrão que lhe garantisse a platéia lotada. Crítico apurado e incisivo, Alcântara Machado encerra sua participação nos periódicos modernistas como o mais importante crítico teatral do período, tendo muito contribuído para o estabelecimento de uma mentalidade vanguardista no processo de modernização do teatro brasileiro.

\section{$\underline{\text { Lanterna Verde }}$}

Formado pela Comissão Diretora da Sociedade Felipe d'Oliveira, Lanterna Verde foi um boletim anual publicado no Rio de Janeiro de 1934 a 1938 e de 1943 a 1944. Seu corpo diretivo era formado por Rodrigues Otávio Filho, Otávio Tarquínio de Souza, Ribeiro Couto e João Daudt d'Oliveira e seus membros e colaboradores eram vários.

O boletim não obedeceu à linha unificadora, mas procurou ser ponto de convergência dos intelectuais brasileiros, sem se prender a tendências, correntes ou opiniões dominantes. Esse propósito, expresso na página de apresentação do boletim, explica a 
presença de colaboradores de várias tendências e de artigos sobre diferentes manifestações da atividade cultural ${ }^{34}$.

No quarto número publicado, Lanterna Verde se propôs a fazer uma revisão geral do Modernismo, apresentando as novas tendências da literatura nacional após 1930. Chamado por Tristão de Ataíde como "pós-modernismo", essa segunda fase do movimento se mantém próxima às outras publicações no que diz respeito à abordagem teatral.

Álvaro Moreyra, crítico responsável por textos dessa natureza, possui duas publicações na primeira fase da revista. Em 1934, o autor descreveu uma viagem pelo teatro nacional, indo desde as 'representações edificantes' de Anchieta até os espetáculos do Trianon. Por fim, reforça a retórica modernista de negação, apontando a ausência de um teatro verdadeiramente nosso (12.3.2.1):

Eis aí... Numa terra onde 80 por cento dos habitantes são analfabetos, e 99 por cento dos que sobram, antes não soubessem ler, tão cedo não haverá teatro. O que há não é bem teatro. É passatempo que substitui, na cidade grande, a bisca e o gamão das cidades pequenas. Bisca... Gamão... Teatro não.

E em 1938, publicou um texto no qual destacou a importância da Commedia dell'Arte para a história do teatro mundial.

Assim, após considerarmos o posicionamento de cada periódico modernista e apresentarmos suas contribuições à temática teatral, podemos concluir que, exceto as matérias publicadas nas revistas Novíssima e Movimento Brasileiro, o discurso modernista deteve-se de maneira muito breve na questão do teatro nacional. Nas poucas manifestações, nota-se a defesa de uma mesma concepção: a ausência de um teatro que refletisse os valores e problemas genuinamente nacionais e a necessidade de se buscar o novo, o inédito tanto na dramaturgia quanto na representação e organização do espetáculo.

Veremos a seguir um discurso totalmente diverso daquele que circulou no mesmo período, só que nas 'Outras Revistas’ por nós pesquisadas.

\footnotetext{
${ }^{34}$ NAPOLI, Roselis Oliveira de. Lanterna Verde e o Modernismo. São Paulo: Publicação do IEB/USP, 1970, p. 21.
} 


\subsection{Outras Revistas}

Já vimos anteriormente que a visão compartilhada por um determinado grupo responsável pela produção de um periódico é determinante na definição da natureza dos artigos publicados, gerando muitas vezes um discurso uniforme e uma posição semelhante em relação a determinado assunto. Dentre os periódicos modernistas, pudemos observar características recorrentes na quantidade e na natureza dos artigos sobre o teatro nacional e também na maneira pela qual os intelectuais modernistas posicionavam-se a respeito da questão teatral no Brasil.

Contrariamente à posição acima apresentada, discorreremos agora sobre um outro grupo de intelectuais que também faziam parte dos formadores de opinião da época: literatos, redatores e diretores de revistas que circularam nos grandes centros brasileiros nas décadas de 20 e 30 . Tentaremos demonstrar de que maneira esses intelectuais abordavam as matérias teatrais e como o gênero e as produções da época eram por eles considerados.

Apesar de terem circulado no período modernista, os periódicos deste grupo afastamse das concepções estéticas e conceituais do grupo anterior. A maior parte deles entrou em circulação antes da Semana de Arte de 22, em meados da primeira década do século XX, com postura e objetivos próprios. Por possuírem um caráter mais tradicional, sua duração foi longa, ultrapassando, em alguns casos, três décadas em circulação. É interessante ressaltar que, mesmo com o alarde modernista pós 22, essas publicações não alteraram suas concepções iniciais e, em muitos casos, nem mesmo registraram a movimentação modernista.

Partiram da intelectualidade carioca a criação e a manutenção desses periódicos. A hegemonia no campo cultural do Rio de Janeiro permitia que as instituições tradicionalistas absorvessem as verbas do governo para a realização de suas atividades. Assim, ancorados em instituições como Academia Brasileira de Letras, Biblioteca Nacional, Instituto Histórico e Geográfico entre outras, os intelectuais pré-modernos encontravam subsídios para a criação de periódicos que garantissem a discussão de uma série de temas que iam desde política e artes até indagações sobre o universo e os planetas.

A variedade de assuntos tratados nesses periódicos pode ter contribuído para a longa manutenção dos mesmos, já que nenhuma postura radical foi adotada. Isso pode ser 
observado na maneira pela qual o teatro nacional foi abordado por esses intelectuais prémodernos e na forma pela qual seus ideais foram sustentados ao longo das primeiras décadas do século.

A grande contribuição deste grupo é o registro de toda a produção teatral que de fato ocupava os palcos nacionais naquela época. Esses fatos, simplesmente ignorados pela geração modernista, revelam uma intensa vida teatral e uma grande circulação de peças e companhias nos principais teatros do Brasil. Em um primeiro momento, podemos destacar a grande quantidade de artigos, notas e peças teatrais publicados nesses periódicos de variedades como um forte argumento contra a ausência do teatro nacional defendida pelo grupo anterior; independente das fontes, das influências e dos temas abordados, havia, sim, uma agitada vida teatral nas décadas de 20 e 30. 
Fon Fon

"Eu sou menina vaidosa que todo coração piso cabeça de melindrosa mais pente do que juízo... „35

O primeiro periódico deste grupo entrou em circulação em 1907, sob a responsabilidade do grupo simbolista formado por Lima Campos, Gonzaga Duque, Mário Pederneiras, Álvaro Moreyra e Hermes Fontes. Intitulada Fon Fon, representando "onomatopeicamente" a buzina dos carros que então invadiam as ruas das grandes cidades, a revista tinha uma característica popular ao abordar assuntos corriqueiros e sem importância $^{36}$. A revista carioca circulou semanalmente de 1907 a 1958 (essa data é imprecisa - acredita-se que tenha sido neste ano sua interrupção devido à ausência de exemplares posteriores). Para nossa pesquisa, consultamos do n. 01 do ano XVI de jan/1922 até o n. 52 do ano XXXVI de dez/1942. Fizemos uma seleção do que julgamos mais importante para o presente trabalho, mas guardamos a certeza de não ter esgotado todo seu material. Acreditamos que a revista merece um estudo único sobre sua matéria, já que apresenta uma publicação vasta e extremamente rica.

Com um grande arquivo de fotos e ilustrações, o foco da revista estava presente na vida das personalidades da alta-sociedade e da esfera política. A citação acima representa toda a natureza da revista, que não tinha pretensões literárias ou vanguardistas; ela retratava os fatos da sociedade, os vestidos e cabelos da moda, as atividades sociais de pessoas importantes, enfim, a verdadeira revista de variedades e ilustração.

Percebe-se que o público da revista, além de se interessar pelas curiosidades da altasociedade, tinha um certo apreço pela produção artística da época. Analisando a revista com mais cautela, destacamos um importante registro sobre diversos campos, como a música, as artes plásticas, o teatro e o cinema. Por ser uma revista semanal, a publicação de artigos e notas teatrais é vasta, proporcionando ao leitor-pesquisador uma importante

\footnotetext{
${ }^{35}$ Citação da capa da Fon Fon, 09 de fev/1924. Ano XVIII, n. 06.

${ }^{36}$ SODRÉ, Nelson Werneck. História da Imprensa no Brasil. 4 ed. Rio de Janeiro: Mauad, 1999. p. 345.
} 
matéria de estudo para o entendimento da posição da crítica e do público a respeito do que se apresentava, em sua grande maioria, nos palcos cariocas.

Entretanto, esse registro acompanhava a natureza da revista; nenhum artigo reivindicatório ou vanguardista é publicado em suas páginas. Os assuntos possuem a profundidade que a revista propõe: informativo em sua grande parte, adicionando algumas entrevistas e enquetes que enriquecem o valor do material coletado.

As matérias teatrais publicadas em Fon Fon tiveram grande importância na elaboração de nosso estudo. Seus registros consideram desde as temporadas líricas em cartaz no Teatro Municipal e Lírico até a presença de companhias italianas e as iniciativas do teatro alemão com suas inovações expressionistas. As realizações nacionais também tinham seu espaço, no apoio à organização do Teatro de Brinquedo, de Álvaro Moreyra e na formação de novas companhias como a Oficial de Comédia Brasileira, do atorempresário Jaime Costa e da Companhia Renato Vianna.

Além de relacionar toda a produção teatral em cartaz nos principais teatros do Rio de Janeiro - o que nos permitiu ampliar nossa visão sobre a produção da época - as páginas de Fon Fon tinham sempre espaço para exaltar dois grandes nomes de nosso teatro: Leopoldo Froes e Procópio Ferreira. O primeiro é citado por diversas vezes, sempre pelo sucesso de suas representações como em O Simpático Jeremias (13.2.1.5); O Violão e o Jazz-Band (13.2.1.17); Gigolo (13.3.4.6); O Modesto Filomeno (13.3.5.2); e mais as peças assinadas por ele mesmo como Mimosa (13.2.1.13) e O Outro Amor (13.3.5.15). Já o segundo ganha destaque por suas representações em Velhice Desamparada (13.2.1.18); Bicho Papão (13.2.1.27); Tio Solteiro, Minha Prima Está Louca e O Baile de Máscaras (13.3.4.8); Que Noite, Meu Deus; Peso Pesado, O Maluco da Avenida e Um Beijo na Face (13.3.4.12) etc.

As críticas aos empresários eram sutis e escassas; e quando apareceriam nunca mencionavam os nomes de Leopoldo Froes e Procópio Ferreira. Domingos Cardoso, em 1924, afirma que:

Os empresários de hoje, porém, são muito diferentes dos de outrora. Querem ganhar muito dinheiro, com poucos gastos, e, lamentavelmente, é o que se tem visto, pois há mais de dez anos que não nos visita uma companhia verdadeiramente digna (13.2.1.15). 
Uma outra valiosa contribuição de Fon Fon é seu extenso registro sobre o desenvolvimento e as realizações do rádio-teatro. Esses artigos e notas chamaram nossa atenção para uma outra modalidade teatral pouco conhecida, mas muito comum na época. Ao percebemos o rico material que tínhamos em mãos sobre esse gênero teatral, optamos por dedicar uma parte desse estudo às realizações do rádio-teatro, que serão abordadas no terceiro capítulo deste trabalho. Todas as informações aqui levantadas serão utilizadas de maneira mais aprofundada nos capítulos que seguem.

\section{$\underline{\text { Ilustração Brasileira }}$}

Dois anos depois da publicação de Fon Fon, surge na imprensa carioca a revista Ilustração Brasileira, quinzenário cultural sob a direção de Álvaro Moreyra e José Carlos, que permanece em circulação até o ano de 1953. Com uma qualidade do papel reconhecida até os dias de hoje, esse periódico afasta-se da natureza de Fon Fon - ela é uma revista mais sofisticada com temáticas menos populares. Há um vasto material histórico publicado nas páginas da revista e uma preocupação política na divulgação dos fatos.

Apesar de não ter apresentado uma quantidade elevada de registros, Ilustração Brasileira teve relativa importância no desenrolar de nossa pesquisa, já que apresentou, ao longo de duas décadas de publicação, um conjunto de peças teatrais publicadas na íntegra somado a vários artigos de cunho histórico sobre a produção teatral nacional e estrangeira.

Registramos em nosso índice a publicação, em formato folhetinesco, de vinte e duas peças de autores nacionais e uma do autor Oscar Wilde, traduzida por Elysio Carvalho. Entre melodramas e comédias ligeiras, destacam-se Cláudio de Souza com Rosas de Espanha (14.1.20), O Marido Surrado e Contente (14.1.22) e Um Esposo Racional (14.1.23); Carlos Maul com Tábua da Salvação (14.1.5) e Os Nossos Índios não Comiam Gente (14.1.11); e Álvaro Moreyra com Adão, Eva e Outros Membros da Família (14.1.13).

Além dos artigos sobre a história do teatro nacional, há também a publicação de artigos que discorriam sobre a situação do nosso teatro na época em questão, considerando tanto as companhias quanto as peças em cartaz nos teatros cariocas.

As idéias referentes à modernização do teatro nacional circularam muito timidamente nas páginas de Ilustração Brasileira, tendo sido registradas apenas duas ocorrências: um 
artigo de Antônio de Alcântara Machado, intitulado "Um aspecto da renovação contemporânea" (14.3.3.1), no qual ele discute a influência do cinema e do café-concerto para o desenvolvimento do teatro moderno no Brasil, e uma conferência realizada por Álvaro Moreyra, intitulada "Teatro que foi e que será" (14.4.2), na qual o autor destaca grandes nomes do teatro moderno europeu e apresenta suas idéias para a realização de seu Teatro de Brinquedo.

Há também um importante registro fotográfico nas páginas da revista que destaca os principais nomes do teatro brasileiro da época e alguns edifícios teatrais do Brasil, como do Teatro São Pedro na época da Independência (14.5.4), do Teatro Municipal de São Paulo (14.5.8), antiga e atual fachada do Teatro Carlos Gomes e Teatro Municipal do Rio de Janeiro (14.5.15), Teatro João Caetano (14.5.18) e antigo Teatro São Pedro (14.5.21).

\section{$\underline{\text { Revista da Academia Brasileira de Letras }}$}

Em 1910, passou a circular nos meios literários a Revista da Academia Brasileira de Letras, que tinha por principal objetivo registrar as discussões, eventos e reuniões dos imortais da Academia. É ampla a contribuição deste periódico ao nosso estudo, já que, a partir das matérias publicadas, podemos compreender de que maneira os intelectuais mais tradicionalistas e conservadores do país expressavam suas opiniões a respeito da vida teatral da época.

Apesar de publicar algumas peças, sua principal contribuição é o registro dos Concursos Literários, realizados anualmente pela Academia, dos quais a dramaturgia nacional fazia parte. Havia uma série de quesitos para a participação dos autores no concurso e o julgamento era feito de modo rigoroso pelos integrantes da Academia. Além da relação das peças concorrentes, a revista traz também os pareceres da comissão julgadora e os vencedores do prêmio. As peças eram analisadas e julgadas enquanto literatura dramática, pois para a Academia:

O teatro é o produto da colaboração do escritor, do ator e do espectador. Se não for isso será simplesmente literatura, matéria prima para teatro ou teatro inatual (sic), em perspectiva, para ser lido por certa classe de leitores que o fazem como dever profissional. Tais são os júris literários (15.3.2.37). 
No parecer da Comissão Julgadora lido em sessão de 2 de setembro de 1926, na qual anunciou-se a peça vencedora do concurso de obras publicadas ou representadas em 1925, apresenta-se uma avaliação literária de cada uma das oito concorrentes. Cláudio de Souza, relator do parecer, anuncia O Homem que Marcha, de Benjamin de Lima como vitoriosa do ano (15.3.2.6). Entre os quesitos analisados estão: o gênero, a originalidade, a linguagem, o desfecho e o assunto. Vejamos abaixo as considerações feitas pela Comissão Julgadora sobre o quesito originalidade:

O assunto nas suas linhas gerais não é inteiramente original, nem há mais assuntos originais em teatro, principalmente no capítulo adultério, que é da especial predileção do teatro francês, tanto antigo como moderno. Se não há mais assuntos originais em teatro, há modos originais de tratar os que sejam mais corriqueiros. E o sr. Benjamin Lima deu muita originalidade à obra que nos apresentou, e que, infelizmente, foi à cena apenas uma vez, quando outras repetem centenários nos cartazes da futilidade. É pena que assim fosse, porque $O$ Homem que marcha é bom teatro.

A Comissão também destacava os pontos fracos das peças vencedoras. Abaixo segue o parecer a respeito da linguagem utilizada por Benjamin de Lima:

$\mathrm{O}$ autor abusa de estrangeirismos e neologismos inúteis, como chaise longue, por espreguiçadeira, fauteuil, em cuja grafia se equivoca repetidas vezes, por poltrona, combatividade, desolação, controlar, interlocar (que de modo algum pode caber na interpretação que lhe deu o autor) serlockismo (sic), mistificação, etc. Serve-se, muitas vezes, de construções galicistas, principalmente de gerúndios e de pronomes pessoais repetidos, que brigam com o gênio da língua.

Entre as peças vencedoras dos concursos estão: 1924, de Paulo Gonçalves, Partida para Citera, de Martins Fontes, Marquesa de Santos, de Luis Edmundo, Gente Sensível, de Jarbas de Carvalho e Pierrot, de Marcius de Avelar (pseudônimo de Paschoal Carlos Magno). Para ver a relação completa das peças que participaram dos concursos e suas respectivas vencedoras, consulte o anexo "Relação das Peças dos Concursos da Revista da Academia Brasileira de Letras". 
Há também nas páginas da revista a publicação de peças de Afrânio Peixoto, Arthur Azevedo, Aluísio Azevedo e Machado de Assis. Um outro registro que merece destaque nas páginas da Revista da Academia Brasileira de Letras é o arquivo biográfico e bibliográfico de autores teatrais de renome em nossa literatura dramática. Lafayette Silva e Arthur Motta encarregam-se da organização desses pequenos estudos, abordando vida e obra de autores como Machado de Assis, Martins Pena, Urbano Duarte, França Júnior, Joaquim Manoel de Macedo, José de Alencar entre outros.

\section{$\underline{\text { Revista do Brasil }}$}

Uma outra importante contribuição ao nosso estudo foi o grupo de matérias publicado na Revista do Brasil, mensário que circulou em diversas fases e por isso acolheu em suas páginas registros de diferentes momentos da nossa história, levando em conta a preocupação com os valores nacionais e com a inserção da nação no contexto internacional.

Inicialmente editada em São Paulo, a revista circulou ininterruptamente entre janeiro de 1916 e março de 1925, constituindo sua primeira fase. Após a falência de Monteiro Lobato, Assis Chateaubriand assume a edição da revista, agora no Rio de Janeiro, promovendo sua segunda fase, que durou pouco mais de quatro meses entre os anos de 1926 e 1927. Após um longo período, a Revista do Brasil volta a circular em 1938, sob a direção de Octávio Tarquínio de Souza, que tenta resgatar algumas características dos primeiros anos. Após a publicação de 56 números, a terceira fase encerra-se em 1943. Sua quarta fase surge em 1944, sob a direção de Frederico Chateaubriand. Bastante modificada em seu formato, não conseguiu agradar ao público e teve a curta duração de três números ${ }^{37}$.

Apesar da dificuldade de localizar alguns exemplares, conseguimos abranger em nossa pesquisa todas as fases da revista, o que nos propiciou uma análise das diferentes concepções sobre o teatro nacional publicadas ao longo das décadas de 20, 30 e início de 40. Iniciamos no ano de 1922, ainda dentro da primeira fase e concluímos em 1944. Apesar da data limite extrapolar a data por nós determinada (1942), nos propusermos ir um pouco além para tentar encontrar reflexos e/ou informações a respeito da representação de Vestido de Noiva.

\footnotetext{
${ }^{37}$ LUCA, Tânia Regina. A Revista do Brasil - Um Diagnóstico para a (N)ação. São Paulo: Unesp, 1999. p. 31 .
} 
Ao analisarmos as matérias teatrais publicadas neste período, pudemos constatar uma divisão de dois grupos distintos no que diz respeito à natureza dos artigos. É claro que os assuntos abordados refletem dois momentos históricos divergentes; entretanto, consideramos importante essa separação para melhor compreendermos a posição dos colaboradores em relação ao teatro nacional.

O primeiro grupo de matérias pode ser definido como a contribuição modernista da Revista do Brasil, publicado entre os anos de 1922 e 1927. Influenciada pelas manifestações modernistas, a revista alinhou-se com os periódicos da época, como Terra Roxa e Outras Terras e A Revista, na tentativa de buscar um caminho para a nacionalização da arte, abrindo espaços para a produção e crítica artística. Nos números da segunda fase, a grande contribuição para a discussão a respeito da modernização do teatro nacional é, mais uma vez, de Antônio de Alcântara Machado. Seus artigos revelam sua insatisfação com a produção nacional, incipiente e sem recursos, e sua oposição àqueles que "choram sentidamente e antecipadamente a morte do teatro, provocada pelo cinema e pelo caféconcerto".

É notável a predominância, nos artigos publicados entre 1922 e 1925, de assuntos históricos, na tentativa de resgatar os valores e as tradições essencialmente nacionais. As matérias teatrais resumem-se a transcrições e noticiários publicados em outros veículos impressos como O Jornal, Jornal do Brasil, do Rio de Janeiro e Mercure de France, de Paris. Já os anos de 1926 e 1927 apresentam uma fase na qual a busca do nacional permanece, mas o foco passa a ser os assuntos artísticos. Apesar da aproximação dos ideais modernistas, a revista abrange diversas correntes, apresentando uma visão ampla do movimento:

O movimento modernista nesta época não apresenta ainda linhas perfeitamente definidas quanto à sua realização propriamente dita. Os modernistas percebem que a fase de destruição já passou, que precisam definir novos rumos, mas não existe nenhuma proposta em relação a isto que os motive e os congregue. Mesmo a necessidade de construção da arte brasileira é um assunto polêmico ${ }^{38}$.

\footnotetext{
${ }^{38}$ IKEDA, Marilda A. Balieiro. Revista do Brasil - $2^{a}$ fase - Contribuição para o Estudo do Modernismo Brasileiro. São Paulo: USP/FFLCH, Dissertação de Mestrado, 1975. p. 82.
} 
Essa ampla abordagem pode ser observada a partir da natureza das matérias teatrais publicadas no período em questão, que traz desde pequenas notas como a estréia da Companhia Tangará no Teatro de Revista (16.2.1.1), até a polêmica travada entre Antônio de Alcântara Machado e Martins de Almeida a respeito da continuidade e da receptividade da arte dramática (16.3.3).

Já o segundo grupo de matérias, compreendido entre a terceira e quarta fases, apresenta uma outra abordagem em relação à produção teatral da época. O próprio teatro nacional já estava direcionando-se para uma abordagem mais moderna, acumulando experiências e tentativas ao longo da década de 30. O foco agora passa a ser na produção internacional, com destaque para o teatro norte-americano. A intelectual Lúcia Miguel Pereira encarrega-se de registrar e analisar as principais peças publicadas em Nova York, como American Landscape, de Elmer Rice e Mary Scotland, de Maxwell Anderson. Além disso, há também um interessante artigo de R. Navarra, intitulado O Drama NorteAmericano (16.3.1.7), no qual o autor apresenta um panorama sobre as principais peças e dramaturgos das primeiras décadas do século XX, como Eugene O’Neill, Elmer Rice e Orson Welles.

Entre a publicação de matérias relacionadas à produção nacional, destaca-se o registro de três importantes peças de renomados autores brasileiros: "Idéias Novas", de Graciliano Ramos, incompleta (16.1.1); "Casa de Poetas", de Lima Barreto (16.1.2) e "Os três malamados", de João Cabral de Melo Neto, esquema de uma peça (16.1.3). Entre os livros resenhados estão Cavaquinho e Saxofone, de Alcântara Machado (16.2.2.4) e Leopoldo Froes e o Teatro Brasileiro, de Alfredo Tomé (16.2.2.10).

A crítica teatral fica por conta de Guilherme de Figueiredo e Carlos Lacerda, responsáveis por registrar as temporadas oficiais, as iniciativas do Serviço Nacional de Teatro, os aspectos estruturais do nosso teatro e as primeiras produções do grupo Os Comediantes, analisando tanto a peça $A$ verdade de cada um, de Pirandello quanto Vestido de Noiva, de Nelson Rodrigues. Essa crítica às realizações do grupo Os Comediantes será melhor explorada no capítulo 4. 


\section{$\underline{\text { Leitura para Todos }}$}

Entre os anos de 1919 e 1928, circulou na imprensa carioca a revista Leitura para Todos. Surpreendentemente, encontramos nesta revista um valioso material de pesquisa, dada a grande quantidade de matérias relacionadas ao teatro, tanto nacional quanto estrangeiro. Mensalmente publicada, a revista aborda os mais variados assuntos teatrais, desde informações históricas a respeito do teatro grego e romano até destaques para a moderna produção européia. Sem sombra de dúvidas, a maior contribuição de Leitura para Todos é seu grande acervo de peças, publicadas integralmente no formato de folhetim. Registramos nos números pesquisados a presença de 34 peças, sendo 11 autores nacionais e 14 estrangeiros. Entre os nacionais, Cláudio de Souza destaca-se com as peças $O$ Exemplo do Padre, Eu Arranjo Tudo! e Os Bonecos Articulados; já entre os estrangeiros estão Maurice Level, com seus pequenos quadros cômicos e Hervé Lauwick com as comédias $O$ Regresso de Ulysses e $O$ Bom Movimento.

É interessante ressaltar que o gênero das peças nacionais publicadas em Leitura para Todos se assemelha ao das peças estrangeiras. $\mathrm{O}$ vasto acervo de peças é composto por comédias de costumes e ligeiras, passatempos, quadros cômicos, moralidades, sainetes e burletas. Nota-se que as peças aqui publicadas eram as peças que ocupavam os palcos nacionais e tinham o respaldo das grandes companhias em cartaz. Não localizamos nenhum representante do teatro moderno estrangeiro (curioso, pois alguns deles são citados na seção de crítica) nem mesmo peças experimentais de autores brasileiros como Antinuos e Moral Quotidiana, publicadas nas revistas modernistas.

A publicação de artigos sobre a história do teatro mundial também é constante, o que nos permite um maior conhecimento sobre as origens do teatro de vaudeville e sobre o Teatro Scala de Milão. Diversos artigos sobre o moderno teatro europeu também estão presentes. Um artigo de Robert Brussel, intitulado "O Teatro" (17.3.3.1), discorre sobre a construção de um teatro experimental na França que permitiria uma vasta combinação de técnicas, medidas de segurança, iluminação e disposição do palco, para que os mais audaciosos metteurs-en-scène pudessem dar forma à sua arte moderna. Além disso, a revista publicou também um importante texto de Jacques Copeau, intitulado "Como foi Criado o Teatro 'Vieux-Colombier"' (17.3.3.2), no qual o autor faz uma descrição da criação do grupo e apresenta suas principais idéias em relação à importância da cenografia, 
ator e texto. Consideramos relevante a reprodução de um trecho no qual ele descreve a estréia de sua companhia:

No fim de 1913, o Teatro do 'Vieux-Colombier' abria suas portas e começava sua primeira 'saison' pela representação de uma peça rude, sóbria e bela de Thomaz Heywood, dramaturgo contemporâneo de Shakespeare: "Uma mulher morta pela dor". Sobre um fundo azulado, permitindo fortes contrastes entre a luz e a sombra, silhuetas nítidas destacavam-se em pleno vapor. Via-se imediatamente, que o que mais nos preocupava ali era a obra, o texto e os personagens; eu digo os personagens e não os comediantes. O publico ficou um tanto surpreso com essa simplicidade que os do 'metier' diziam excessiva. A troupe cada vez mais entusiasmada interpretou obras dramáticas das mais diversas: Shakespeare, Molière, Musset; e os modernos: Becque, Jules Renard, Jean Schlumberger, Roger Martin du Gard, Paul Claudel, Henri Ghéon, Crouè, Copeau. Mas um sucesso formidável veio coroar esse ano de pesquisas: foi por ocasião da 'Nuits des Rois', a maravilhosa comédia fantasista de Shakespeare que foi representada, quase sem cenários e cuja revelação inesperada e estrondosa fez que atribuíssem o sucesso à 'mise-em-scène' quando ele era apenas devido à obra-prima que era a peça. Desde esse momento, tateando, pois não conhecíamos bem o 'metier' que era novo para nós, aclaramos e experimentamos nossos princípios. Foi nessa ocasião que rebentou a guerra.

A partir daí Copeau conta de que forma sua troupe foi influenciada pela guerra e pelas imposições do Estado, que afetou não apenas as temporadas de verão, mas também a composição dos membros da companhia. Por outro lado, a guerra permitiu que outras partes do mundo tomassem conhecimento das inovações do Vieux-Colombier:

Bem se sabe que [...] era necessário dar à colaboração da América nessa guerra de usura que parecia nunca acabar. Quando se pensou em criar, além-mar, um meio de influência francesa, imediatamente sentiram o papel importante que o teatro teria nessa influencia e - coisa paradoxal e significativa - foi no "Vieux-Colombier" que o Governo pensou. 
Essa iniciativa visava abrandar a influência alemã nos centros culturais norteamericanos, exercida por instrumentos artísticos, como os espetáculos de Max Reinhardt. Além da representação de sua companhia nos palcos de Nova York, Copeau apresentou suas concepções dramáticas em diversas conferências que realizou, mobilizando vários grupos contra o teatro comercial da Broadway ${ }^{39}$.

Diversos outros autores e atores modernos são citados e estudados nas páginas da revista, entre eles Maeterlinck, Ibsen, Pirandello e Ermette Zacconi. Comparado à produção estrangeira, o teatro nacional ocupa um espaço mais reduzido, tendo sido registrados estudos sobre França Junior e Paulo de Magalhães e uma importante crítica feita por Múcio Leão à carência do teatro nacional. Em seu artigo "O Teatro Nacional” (17.3.2.1), ele aponta o caráter negativo de nossas companhias em levar ao palco "costumes inteiramente falseados, com banalidades ridículas e um propósito horrível de fazer rir por qualquer coisa". Vale observar que esse posicionamento crítico de Múcio Leão não condiz com as publicações das peças teatrais nas páginas da revista, já que a grande maioria dela apresenta costumes falseados e um propósito claro de fazer rir, rir e rir.

A parte fotográfica da revista está em consonância com o gênero das peças publicadas. Ela apresenta uma série de fotos de cenas de peças em cartaz nos palcos nacionais como as comédias Longe dos Olhos..., de Abbadie Faria Rosa; Nossos Papás, de Ribeiro Couto e Onde Canta o Sabiá, de Gastão Tojeiro, todas no palco do Trianon.

É possível inferir que os leitores da revista Leitura para Todos tinham acesso a um amplo material relacionado ao teatro nacional e estrangeiro, já que a revista era um importante veículo de circulação não apenas da produção teatral nacional, mas principalmente das concepções de teatro moderno, em franca expansão na Europa. Torna-se assim, um objeto de estudo relevante para a compreensão das idéias teatrais da época.

\section{$\underline{\text { A Cena Muda }}$}

Passemos agora às matérias encontradas n'A Cena Muda, revista semanal de caráter popular que teve grande circulação entre os anos de 1921 e 1955. A revista, essencialmente sobre cinema, abria brechas para outros meios de comunicação como o teatro e o rádio. Sem pretensões intelectuais e elitistas, direcionava-se para o grande público, para o

\footnotetext{
${ }^{39}$ MIGNON, Paul-Louis. Jacques Copeau ou le Mythe du Vieux-Colombier. Paris: Julliard, 1993. p. 144.
} 
verdadeiro fã e adorador dos "mitos hollywoodianos". O foco da revista estava nos resumos de filmes, publicados como folhetins semanais, sempre acompanhados de muita ilustração e fotografia. As informações sobre as filmagens e sobre a vida dos artistas dividiam espaço com a grande quantidade de fotografias nas páginas da revista.

A pesquisadora Flora Christina Bender, em seu importante estudo sobre essa revista, divide o grande número de exemplares em quatro fases distintas, levando em conta a estrutura, os temas abordados e a posição dos colaboradores em relação às produções do cinematógrafo e posteriormente, do cinema. Os números por nós pesquisados (05/01/1922 até 28/07/1942) coincidem com os da primeira fase proposta por Bender, denominada "A revista especializada em cinema" ${ }^{40}$. As seções fixas 'Novidades na tela' e 'Os que vivem no écran' traziam notícias sobre o mundo do cinema, principalmente o americano. De acordo com a autora, esta é a fase do "endeusamento incondicional do astro, da estrela", na qual o maior interesse estava na particularidade da vida dos artistas de Hollywood.

A criação e implantação do mito de Hollywood e do 'star system' consagrado fazia-se também às custas de toda a publicidade que envolvia as fitas, seus astros e estrelas. $\mathrm{O}$ crescimento do mercado cinematográfico entre nós, ou seja, dos negócios de exibição e importação de filmes, exigia cada vez mais a presença dos 'jornalistas cinematográficos ${ }^{41}$.

Com a expansão desse novo mercado, uma série de revistas especializadas em cinema surgiu no periodismo nacional, como Cinelândia, Filmelândia e Cinearte; mas nenhuma delas alcançou o sucesso d'A Cena Muda.

As matérias teatrais aparecem timidamente nos últimos anos da primeira fase, concentrando-se nos anos de 1941 e 1942. Sylvia Moncorvo era a responsável pelas seções 'Telas, Palcos e Microfones' e 'Artistas de Teatro e Artistas de Cinema', registradas em nossa pesquisa a partir de 1941. A primeira registra diversas notas sobre as estréias teatrais do momento, entre elas $O$ Marido da Estrela, de Paulo de Magalhães; Carneiro Batalhão, de Viriato Correa e Esquecer, de Luiz Peixoto e Tobias Moscoso. Já a segunda apresenta

\footnotetext{
${ }^{40}$ BENDER, Flora Christina. Cena Muda. Tese de Doutorado. São Paulo: USP/FFLCH, 1979. p. 11.

${ }^{41}$ QUEIROZ, Eliana. A Scena Muda - Como Fonte para a História do Cinema Brasileiro (1921-1933). Dissertação de Mestrado. São Paulo: USP/ECA, 1981. p. 17.
} 
sempre uma breve biografia e os principais trabalhos de um artista do palco e outro da tela. Entre os atores teatrais destacam-se Gilda Abreu, Itália Fausta, Procópio Ferreira, Olga Navarro, Margot Louro, Zaira Cavalcante, Eva Todor, Sandro Poloni, Lygia Sarmento e Iracema de Alencar ${ }^{42}$.

Constatamos então que a maioria das notas e artigos publicados sobre o teatro nas páginas d'A Cena Muda estava relacionada, de uma forma ou de outra, ao cinema nacional ou estrangeiro. Não registramos nenhuma crítica mais elaborada sobre a produção teatral nacional, resenhas de espetáculos ou debates que impulsionassem o teor moderno de nossos palcos. Sua contribuição é essencialmente informativa por meio de citações breves.

\section{Boletim da Sociedade Brasileira de Autores Teatrais}

Criado sete anos após a fundação da Sociedade Brasileira de Autores Teatrais, o Boletim da S.B.A.T. circulou mensalmente durante vários anos na imprensa carioca. Ao longo de sua existência, deixa de ser Boletim e passa a ser Revista, ampliando sua estrutura e as discussões sobre o teatro e a vida teatral.

Os números por nós pesquisados ainda eram boletins, com poucas páginas, de caráter puramente informativo. Não foi registrado neste período nenhum artigo de natureza mais crítica, apenas notas sobre o expediente da Sociedade e sobre as peças em cartaz nos teatros do Brasil. As seções do boletim eram basicamente as mesmas; elas dividiam-se em: 'Expediente', 'Atas', 'Falecimentos', 'Assuntos em voga', 'Nossos autores', 'Conferências e Balancete (Noticiário e Relação dos Sócios)'.

Pudemos conhecer a posição de alguns membros da S.B.A.T. por meio de transcrições de Conferências publicadas nos primeiros números do boletim. Entre elas estão: D. Ruth Ribeiro com "Por que não temos teatro?” (19.4.1); Valeriano Machado com “Teatro no Brasil e em Portugal” (19.4.2); Rego Barros com “O teatro por dentro" (19.4.4), e Ivete Ribeiro com "Os anônimos do teatro" (19.4.5). Além disso, uma outra contribuição da revista é a listagem das peças em cartaz pelos palcos brasileiros. Sendo o boletim dedicado exclusivamente aos assuntos teatrais, decidimos, por conta de razões

\footnotetext{
${ }^{42}$ Segundo Sylvia Moncorvo, a seção 'Artistas de teatro e de cinema' era irradiada todas as terças-feiras pela PRG 3, Rádio Tupi, na hora do Jornal dos teatros, a cargo do ator Olavo Barros (n. 1069, de 16/9/41).
} 
metodológicas, registrar as ocorrências mais relevantes ao nosso estudo, já que o boletim merecia, pela quantidade de informações, um estudo exclusivo de sua matéria.

Dessa forma, registramos algumas peças que estavam em cartaz, sempre nos meses de abril e setembro de cada ano e os principais artigos sobre um determinado autor ou ator. Esse levantamento foi extremamente relevante, pois nos permitiu ter um panorama das peças que eram encenadas, principalmente no eixo Rio - São Paulo. O teatro de revista e a comédia de costumes eram os gêneros predominantes nos palcos e valorizados pelas grandes companhias teatrais e também pelo público, que lotava as casas de espetáculos. Nomes como Viriato Correa, Paulo de Magalhães, Armando Gonzaga, Gastão Tojeiro, Cláudio de Souza, Abadie Faria Rosa, Manoel Bernardino, Luis Peixoto, C. Bitterncourt e Cardoso Meneses eram freqüentes nos balancetes da S.B.A.T ${ }^{43}$. No capítulo 2, nos deteremos na análise desses autores e de suas contribuições para o teatro nacional.

Localizamos também a seção 'Esboços Biográficos de Autores Teatrais', na qual destacam-se os estudos sobre Gastão Tojeiro, Armando Gonzaga, Celestino da Silva, Ataliba Reis (João Cláudio), Miguel Santos, Abadie Faria Rosa, Paulo de Magalhães, entre outros.

Assim, tentamos apreender do Boletim da Sociedade de Autores Teatrais o máximo de informações possíveis para o nosso estudo, levando-se em conta o caráter informativo que será substituído mais tarde com a implantação da Revista da S.B.A.T.

\section{$\underline{\text { O Mundo Literário }}$}

Poucos meses após a Semana de Arte Moderna, precedendo a publicação da revista Klaxon, surgia na imprensa carioca $O$ Mundo Literário, sob a direção de Pereira da Silva e Théo-Filho. Seu propósito inicial era estudar as obras literárias brasileiras e estrangeiras sob uma visão crítica e divulgar novos autores nos círculos intelectuais da cidade. Apesar de ter recebido a colaboração de nomes ligados ao Modernismo, a revista, inicialmente, defendia a noção de arte como missão social, capaz de exercer influência sobre o meio. Podemos perceber, nos textos de apresentação publicados nos primeiros números da

\footnotetext{
${ }^{43}$ Para ver a relação completa das peças que estavam em cartaz na época, consulte anexo "Relação das Peças em Cartaz".
} 
revista, o respeito pelo passado e pela tradição e a intenção de incorporar valores, conceituais e estéticos, da geração passada.

Sua atitude de respeito pela tradição e total defesa do passado ante a renovação mostra um ponto básico de divergência com os modernistas e situa-o numa esfera inteiramente diferente daquela em que surgiu Klaxon, por exemplo. ${ }^{44}$

Com o aumento da circulação das idéias modernistas por meio da publicação de novos periódicos, essa posição primeira d'O Mundo Literário foi aos poucos se alterando. Registra-se nas páginas da revista uma coexistência de posições diversas, sejam elas conservadoras ou reacionárias. É curioso observar que alguns colaboradores, como Tristão de Ataíde, Murilo Araújo, Andrade Murici e Renato Almeida, auto-denominados o "espírito novo" da revista, foram os responsáveis pela publicação da revista modernista Festa em $1927^{45}$.

Em relação à questão teatral, $O$ Mundo Literário revela-se um periódico atento às produções da época, tanto às peças quanto às montagens. Registramos em nosso índice a publicação de cinco peças ou trechos de peças nas páginas da revista, sendo que três delas estavam em destaque nos palcos do país: Somos o que elas querem, de Ruy Castro (20.1.3), em processo de ensaio pela Companhia Leopoldo Froes; Faze o que digo, de Gastão Tojeiro (20.1.4), no Teatro Carlos Gomes; e Os Vendilhões, de Baptista Júnior (20.1.1), aprovada para ser representada nas comemorações do Centenário da Independência. Na seção 'Antologia dos Novos', encontramos a publicação de uma cena do terceiro ato da comédia Nossa terra, do então iniciante Abadie Faria Rosa (20.1.5).

Além disso, encontramos a notificação dos sucessos e fracassos das companhias nacionais, da temporada francesa no Teatro Municipal e das contribuições de Lugné-Poe ao teatro francês. Múcio da Paixão encarrega-se da autoria de dois artigos de caráter histórico sobre o teatro brasileiro no período colonial e nos tempos de Regência. Há também um interessante material para os interessados em teatro brasileiro: o estudo de Miguel Santos,

\footnotetext{
${ }^{44}$ CHAVES, E. M. O Mundo Literário - Um Periódico da Década de 20 no Rio de Janeiro. Vol.1. São Paulo: USP/FFLCH, Dissertação de Mestrado, 1977. p. 38.

${ }^{45}$ Idem. p. 129.
} 
intitulado "Pseudônimos dos Nossos Autores Teatrais" (20.3.2.8), no qual o autor apresenta uma coletânea de pseudônimos usados no teatro e na imprensa por autores nacionais.

\section{Frou Frou}

O periódico Frou Frou, dirigido por Antonio Guimarães, ficou em circulação na imprensa carioca durante os anos de 1923 a 1935. Apesar de não termos conseguido localizar sua coleção completa, registramos nos números pesquisados um importante levantamento de dados, principalmente em relação ao teatro nacional. Sem grandes pretensões estéticas e conceituais, a revista possuía um caráter mais popular, publicando muito mais notas informativas do que debates de idéias a respeito de um determinado assunto.

A grande contribuição da revista está na seção 'O que se promete', com a divulgação das peças que entrariam em cartaz nos principais teatros do Rio de Janeiro. A partir dela, pudemos fazer um levantamento tanto das companhias quanto dos autores que ocuparam a cena nacional, principalmente na década de 20. A seção 'No palco e no écran' encarregavase das notas diversas, relatando as estréias, a movimentação das companhias nacionais e estrangeiras e o êxito de um determinado ator ou autor.

A situação do teatro nacional é debatida brevemente. Mário Nunes assina dois artigos, nos quais aponta a necessidade de criação de escolas teatrais e da promoção de concursos que revelem novos dramaturgos e também critica a inação dos empresários como Procópio Ferreira, Paschoal Segretto e M. Pinto, que não inovam seus espetáculos para não prejudicar as bilheterias.

Um outro artigo interessante é o "Teatro nacional e o teatro d'avant-garde", de A. de Queiroz (21.3.3.2), no qual o autor apresenta a nova iniciativa de Álvaro Moreyra e René de Castro. Dando continuidade ao Teatro de Brinquedo, Moreyra cria agora o Cenáculo dos Amigos da Arte, na tentativa de estabelecer o teatro avant-garde nos palcos nacionais. Queiroz afirma que em nenhum momento da nossa história deverá se impor o teatro moderno na produção nacional; ele deve ser constituído e desenvolvido aos poucos, para que possa ser compreendido por todos.

Em relação ao teatro moderno estrangeiro, destaca-se o artigo "Nós e os modernos" (21.3.2.5), sem indicação de autoria. Aqui, o autor critica a falta de conhecimento dos 
brasileiros de nomes como George Kaiser, Bernard Shaw, Strindberg, Pirandello, entre outros. Para ele, o argumento de que o nosso público não está preparado para receber peças modernas é infundado; é apenas uma saída simples para os grandes empresários, que insistem na produção do século XIX.

Completando o conjunto de contribuições da revista Frou Frou está seu amplo acervo fotográfico, com destaque para atores e autores em cartaz na cidade. Esse acervo se assemelha muito ao publicado pela revista Leitura para Todos, já que traz fotos de atores consagrados como Armando Gonzaga, Viriato Correa e dos integrantes das Companhias Lírica, da Dramática Francesa e de Carlos Campos e também, de cenas de peças representadas nos palcos no Trianon. Pelo conteúdo apresentado, nota-se uma aproximação de Leitura para Todos com Frou-Frou.

\section{Boletim de Ariel}

No início da década de 30, surgia no Rio de Janeiro um periódico intitulado Boletim de Ariel, com direção de Gastão Cruls, que se propunha a discutir artes, ciências e história. Publicado semanalmente, o boletim circulou de 1931 a 1939, tendo Agrippino Grieco como redator-chefe e diversos colaboradores.

Passado a década de 20, a intenção dos intelectuais e literatos da época era de contribuir com regularidade para a destruição da literatura anacrônica e para a implantação de idéias novas. Segundo Afrânio Coutinho, "essa característica do Modernismo vai desembocar, decantadas as impurezas e os excessos, num tipo de revista exclusivamente crítica e bibliográfica, como ela própria se intitulava, e na qual escritores das mais diversas especialidades colaboravam com notas críticas" ${ }^{46}$. O Boletim de Ariel era muito mais objetivo que polêmico.

Apesar de ser publicado na imprensa carioca, sua maior contribuição está na divulgação da produção teatral de outros estados como Minas Gerais e São Paulo. O olhar atento passa agora a ser sobre as produções mais elaboradas e as iniciativas que apresentem características ousadas e modernas.

A primeira iniciativa paulista a ser registrada nas páginas da revista é o Teatro da Experiência, estreando com a peça $O$ bailado do Deus morto, de Flávio de Carvalho, com

\footnotetext{
$\overline{{ }^{46} \text { COUTINHO, Afrânio. Op. cit. p. } 617 .}$
} 
realização do Clube dos Artistas Modernos. O autor aplaude a apresentação e a considera como "primeira tentativa de modernizar nosso pobre teatro". Ao encerrar, o autor divulga que a segunda peça da companhia será $O$ homem e o cavalo, de Oswald de Andrade.

No ano seguinte, 1934, registramos uma crítica de Jorge Amado à Censura Nacional, que vetou a representação da peça de Oswald pelo Teatro da Experiência. Segundo o autor, O homem e o cavalo é uma das mais sérias peças que o teatro nacional já teve e não poderá ser encenada devido à autocracia de poucos. Jorge Amado conclui dizendo que "terminou o palhaço da burguesia; começou o casaca de ferro da revolução proletária”.

Esta mesma peça ganha mais uma vez destaque na resenha publicada em setembro de 1934, sem indicação de autoria. A partir de uma breve análise, o autor aponta o caráter de literatura de combate e de "alegoria cênica destinada a suscitar implacáveis atritos de inteligência".

Outras duas peças ganham destaque nas páginas do Boletim de Ariel: Marquesa de Santos de Viriato Corrêa e Deus lhe Pague, de Joracy Camargo. A primeira obteve um enorme sucesso nos palcos do Teatro Sant'Ana em São Paulo, pela Companhia DulcinaOdilon; já a segunda é elogiada pelas qualidades de seu autor, que leva ao palco o personagem do mendigo, abordando, pela primeira vez, os problemas imediatos do Brasil, dando ao teatro brasileiro um caráter social até então desconhecido.

As informações sobre o teatro estrangeiro ficam sob a responsabilidade de José Maria Senna, que apresenta informações históricas do teatro japonês, o caráter religioso do teatro tibetano e as inovações cênicas do teatro judeu. Para ilustrar suas análises, o autor utiliza trechos de peças de alguns dos principais representantes dessas regiões.

Apesar de o Boletim de Ariel não apresentar um vasto material, ele contribui com nosso estudo na medida que muda o foco dos palcos cariocas para outras cidades, permitindo-nos ampliar nossa visão sobre a produção teatral nacional.

\section{$\underline{\text { Revista Brasileira }}$}

A quarta fase da Revista Brasileira entra em circulação em julho de 1934 e sai de cena em novembro de 1935. Dirigida por Baptista Júnior, a revista traz uma importante carga histórica, por já ter circulado em outros momentos na imprensa carioca. Sua proposta 
é basicamente a mesma; o mundo contemporâneo continua sendo o principal assunto, bem como o progresso, que apenas será atingido no sistema "conservar melhorando".

Saul de Weston encarrega-se de atualizar os leitores sobre o meio teatral, por meio de notas sobre estréias, resenhas das peças e análise dos espetáculos em cartaz. Suas informações formam um importante conjunto de registros do teatro da época, principalmente em relação ao teatro carioca. Renato e Oduvaldo Vianna ganham destaque nas páginas da revista. O primeiro, por sua direção da Companhia Teatro Escola, que estreou no Teatro João Caetano em 1934; a temporada do ano seguinte traz Itália Fausta e Delorges Caminha no elenco das peças Sexo, do próprio Renato Vianna e História de Carlitos, de Henrique Pongetti. Já Oduvaldo Vianna aparece com as peças Amor e Canção da Felicidade; a encenação da segunda recebe destaque por apresentar o palco dividido em três espaços cênicos. Saul de Weston ainda destaca as atuações de Dulcina, Vanda Marchetti e Aristóteles Penna.

Um outro artigo de Saul registra as tentativas iniciais de Heckel Tavares na criação de um teatro infantil brasileiro, que tinha por principal objetivo a educação das crianças. $\mathrm{O}$ autor explica como será a construção cênica do palco, a constituição do espaço, da luz, do movimento e da fantasia. Ilustram o artigo gravuras explicativas da estruturação do palco, que dividido em três dimensões, proporcionará luz em diversos pontos, gerando efeitos de claro-escuro e movimentação.

É interessante observar que estruturas cênicas modernas já eram planejadas e, em alguns casos, utilizadas, promovendo um caráter moderno a alguns espetáculos da década de 30. Veremos a divisão do palco em diferentes dimensões na peça-marco do moderno teatro brasileiro, Vestido de Noiva, de Nelson Rodrigues, levada à cena pelo grupo Os Comediantes. Com os artigos da Revista Brasileira, podemos afirmar que algo da concepção cênica realizada em 1943 já havia sido idealizado na década anterior.

A implementação do Estado-Novo em 1937 trouxe ao país uma série de mudanças políticas e econômicas que afetaram sensivelmente o meio de comunicação em voga na época: a imprensa escrita. Como já foi dito anteriormente, com o regime da censura, diversos jornais e periódicos deixaram de existir, ou passaram a ser vigiados de perto pelos censores do Governo. A imprensa passa a ser o veículo mais eficiente do discurso estado- 
novista, voltado prioritariamente para o exercício da censura e da propaganda do regime ${ }^{47}$. Entre as publicações que surgiram a partir de 1937, selecionamos cinco para nossa pesquisa: Dom Casmurro, Anuário Brasileiro de Literatura, Mensagem, Clima e Cultura Política.

É interessante observar a maneira pela qual estas revistas contribuem não apenas para a construção de um discurso do governo, mas também para a criação e manutenção da imagem de Getúlio Vargas, que concentrava em si diversos papéis:

O mito Vargas constrói-se à base de um múltiplo jogo de imagens que o mostram ora como homem comum, identificado com o povo, ora como político eficiente, realizador de inúmeras reformas na ordem social, ora como verdadeiro líder, investido de dotes especiais $^{48}$.

Ao considerarmos o modo pelo qual a questão teatral é tratada, podemos delinear abordagens semelhantes nos artigos publicados. É interessante observar que apesar da censura, a quantidade de registros sobre o assunto é vasta, não apenas no noticiário, mas também nos debates sobre a situação do teatro nacional. $\mathrm{O}$ desenvolvimento cultural do país é uma das preocupações do Estado-Novo, que visava promover novas criações e pensamentos, manter costumes e tradições, harmonizando os interesses por meio da ordem política.

Com o decreto-lei n ${ }^{2}$ 29, de 21 de dezembro de 1937, Getúlio Vargas e o Ministro da Saúde e da Educação, Gustavo Capanema, criam o Serviço Nacional de Teatro para apoiar o teatro nacional, definido no decreto como "expressão da cultura nacional" que tem por objetivo "a elevação e a edificação espiritual do povo". De acordo com o artigo $3^{\circ}$, compete ao S.N.T. as seguintes funções: "a) promover ou estimular a construção de teatros em todo o país; b) organizar ou amparar companhias de teatro declamatório, lírico, musicado e coreográfico; c) orientar e auxiliar, nos estabelecimentos de ensino, nas fábricas e outros centros de trabalho, nos clubes e outras associações, ou ainda isoladamente, a organização de grupos amadores de todos os gêneros; d) incentivar o teatro para crianças e adolescentes,

\footnotetext{
47 VELloso, Mônica Pimenta. Cultura e Poder Político. In: OLIVEIRA, L. L. et alli. Estado Novo: Ideologia e Poder. Rio de Janeiro: Zahar Editores, 1982, p. 73.

${ }^{48}$ Idem. p. 95.
} 
nas escolas e fora delas; e) promover a seleção dos espíritos dotados de real vocação para o teatro, facilitando-lhes a educação profissional no país ou no estrangeiro; f) estimular, no país, por todos os meios, a produção de teatro de todos os gêneros; g) fazer o inventário da produção brasileira e portuguesa em matéria de teatro, publicando as melhores obras existentes; h) providenciar a tradução e a publicação das grandes obras escritas em idioma estrangeiro"49.

Dessa forma, o S.N.T. reavivou os meios teatrais, oferecendo subsídio oficial às companhias e promovendo diversos programas culturais. Entretanto, foi nessa época que o nosso palco conheceu um dos mais severos regimes censórios já instituídos no país:

\footnotetext{
Durante alguns intermináveis anos, tudo seria proibido, até referências à guerra de que então o Brasil já participava. Talvez por isso, talvez pelo morno ambiente moral e intelectual imperante, de conformismo em face do inevitável conflito internacional, inclinava-se a dramaturgia brasileira para outros gêneros, menos comprometidos e menos comprometedores ${ }^{50}$.
}

Por conseqüência, o incentivo do governo estava destinado à exaltação do nacionalismo, por meio dos grandes personagens da história brasileira. Entram em cena no final da década de 30 as peças históricas, como Marquesa de Santos, de Viriato Corrêa e Carlota Joaquina, de Raimundo Magalhães Júnior. Essas peças ganham espaço e passam a concorrer com as comédias ligeiras, grandes sucessos da década de 20. Incentivar e subsidiar as peças históricas pode ser entendido como uma maneira de valorizar a história nacional, exaltando nossas conquistas e valores. Essa manobra se adequava perfeitamente à estratégia política do novo regime que se instaurou ao longo da década de 30.

Com efeito, o teatro ganhou um grande espaço entre as publicações periódicas da época. Veremos como cada uma das revistas citadas acima se posicionou e colaborou com o registro da vida teatral.

\footnotetext{
${ }^{49}$ Decreto-Lei no 29, In: SOUSA, J. Galante. O Teatro no Brasil. Tomo I, Rio de Janeiro: Instituto Nacional do Livro, 1960, p. 336.

${ }^{50}$ PRADO, Décio de Almeida. O Teatro Brasileiro Moderno. 2ed. São Paulo: Perspectiva, 2003, p. 35.
} 


\section{Dom Casmurro}

O hebdomadário Dom Casmurro destaca-se como uma das principais contribuições desta pesquisa, já que foi a fonte primária que nos proporcionou o maior número de registros no nosso índice. Por ser uma publicação semanal, pudemos acompanhar de forma gradual as mudanças da vida cênica, a circulação das companhias e das peças em cartaz, bem como os debates entre os colaboradores do periódico, que sempre apresentavam os dois lados de uma mesma questão.

Periódico de valor artístico, cultural e político, Dom Casmurro circulou na imprensa carioca de 1937 a 1946, sob a direção de Brício de Abreu e principal colaboração de Álvaro Moreyra. Tendo dois representantes da vida teatral da época à frente da publicação, as discussões, iniciativas e realizações da área ganhavam destaque.

Constatamos nas páginas de Dom Casmurro o grande apoio dado às produções nacionais, seja na concepção dramática, seja na organização de novas companhias. O elemento nacional ganha força e a defesa da instituição de um teatro verdadeiramente brasileiro volta à baila, agora com novos argumentos e personagens: a Sociedade Brasileira de Autores Teatrais e o Serviço Nacional de Teatro.

Entre os textos dramáticos, registramos a publicação de 14 peças, sendo 12 nacionais e 2 estrangeiras. No ano de 1942, o hebdomadário passa a publicar um caderno especial que trará, na primeira semana de cada mês, uma peça teatral brasileira de grande êxito, em prol da cultura e da intelectualidade brasileira. Segundo Brício de Abreu, diretor do periódico, a intenção é facilitar a circulação de originais, que são publicados, na maioria dos casos, às custas do autor. Entre as peças publicadas no caderno especial estão: A comédia do coração, de Paulo Gonçalves; O Burro e Sindicato dos Mendigos, de Joracy Camargo; Iaiá Boneca, de Ernani Fornari; e Carlota Joaquina, de Raymundo Magalhães Júnior ${ }^{51}$.

Quase toda movimentação das companhias nacionais era registrada em notas sem indicação de autoria ou no edital de Álvaro Moreyra, intitulado Bom dia! As estréias da Companhia Jaime Costa, da Companhia Dramática Álvaro Moreyra, as iniciativas do Teatro do Estudante, d'Os Comediantes e do Teatro Universitário foram amplamente

\footnotetext{
51 Apesar da indicação da publicação das peças no corpo da revista, não conseguimos localizar o caderno especial nem nas bibliotecas visitadas, nem no material microfilmado da Faculdade de Filosofia, Letras e Ciências Humanas da USP.
} 
divulgadas e discutidas pelos colaboradores da revista, sempre questionando o baixo incentivo dado pelos órgãos oficiais e a necessidade de se educar as nossas platéias.

Brício de Abreu (pseudônimo Ludo), principal crítico teatral de Dom Casmurro, aponta por diversas vezes as conquistas do teatro amador de alta qualidade, realizado quase sempre sem a ajuda do Governo. Na ocasião da estréia do Teatro do Estudante do Brasil, grupo organizado por Paschoal Carlos Magno, o autor registra seu contentamento com a iniciativa, ironizando a falta de subsídios por meio de uma carta destinada ao Destino (24.3.5.7):

\section{"Sr. Destino,}

No Brasil, tudo o que já se fez de bom em teatro, tudo o que vale a pena foi feito fora das coisas 'oficiais' e sem subvenções. Ora, isso quer dizer que o que temos é, portanto, pouco, de bom e visível, é claro - assim sendo, precisamos para o Teatro de elementos novos e com fibra. Doutra parte, como o sr. sabe, sr. Destino, o Brasil está cheio, cheinho assim de advogados, médicos, e doutores - assim, ainda, podia o senhor fazer com que aqueles rapazes todos da Companhia da Casa dos Estudantes fossem reprovados e expulsos das escolas e ficassem no Teatro. Em compensação, sr. Destino, eu juro não ir nunca mais a companhias organizadas pela Prefeitura ou oficializadas. De V. S. com a maior raiva,

\section{LUDO”.}

Os incentivos do Serviço Nacional de Teatro limitavam-se a poucas companhias e não abrangiam toda a produção nacional. A primeira concessão foi dada a Jaime Costa e Álvaro Moreyra que, com um auxílio de 600 contos, deveriam organizar novas companhias nacionais de teatro.

As decisões tomadas pelos diretores do S.N.T. eram sempre contestadas por diversos nomes do teatro brasileiro nas páginas de Dom Casmurro. Brício de Abreu, responsável pelo edital da revista, acompanhava de perto as iniciativas dos diretores e criticava sem rodeios nomes como Bandeira Duarte e Abadie Faria Rosa. O autor acusava os diretores do S.N.T. de lucrar com os grandes empresários teatrais, prejudicando companhias menores. No final de 1939, as críticas contra Faria Rosa intensificam-se quando Raimundo Magalhães Júnior acusa-o formalmente de impor peças de sua autoria às companhias 
subvencionadas. As peças Suicídio por amor, Levada da Breca, Crepúsculo e Longe dos Olhos, todas de autoria do diretor do S.N.T., entraram em cartaz em 1940.

É curioso observar que, apesar das críticas severas à má administração do Serviço Nacional de Teatro, o vilão era sempre o diretor do Serviço; tanto o presidente Getúlio Vargas quanto o ministro Capanema eram poupados das acusações. Isso fica claro nas palavras de Brício de Abreu, que ao apontar as medidas de renovação da temporada de 1940, destaca o Ministro Capanema como um "homem equilibrado, inteligente e culto", que conta com o apoio do Presidente Vargas, "homem que conhece o nosso teatro a fundo e as suas necessidades, já tendo sido crítico".

Apesar de não ter sido pesquisada toda a produção de Dom Casmurro, por conta do grande número de publicações - o periódico em questão mereceria um estudo exclusivo de sua matéria - registramos um precioso material de estudo para a compreensão do teatro brasileiro da época. Utilizaremos essas contribuições nas análises desenvolvidas nos capítulos a seguir.

\section{Anuário Brasileiro de Literatura}

O Anuário Brasileiro de Literatura surge em 1937 no Rio de Janeiro sob a direção de Henrique Pongetti, com o objetivo de fazer um balanço de todas as realizações no campo da literatura, da música, das exposições, do teatro e do cinema durante o ano e questão.

O anuário destaca as temporadas teatrais dos anos de 1938, 1939 e 1941, sendo Bandeira Duarte o responsável pela análise das principais peças e companhias que ocuparam os palcos no ano anterior. Podemos perceber a mudança da avaliação da qualidade do Serviço Nacional de Teatro, já que em 1938 Bandeira Duarte ressalta a organização do órgão - dirigido por Abadie Faria Rosa - que se destacou pelas peças que levou aos palcos cariocas. Entretanto, em 1939, o mesmo autor aponta o fracasso da iniciativa do Serviço, que pouco fez pelo nosso teatro. O sucesso continua sendo das peças históricas e das escritas para fazer rir.

Além disso, o crítico também registra os autores de maior êxito popular como Mello Nóbrega, J. Barroso e Raul Pedrosa. Uma outra importante contribuição é o artigo de Luis Martins, intitulado R. Magalhães Júnior no Teatro Nacional, no qual o autor destaca o 
sucesso das peças históricas na temporada de 1938. Para ele, a opção por esse gênero é uma tendência dos autores nacionais devido "à melancolia da vida cotidiana" (25.3.5.1).

\section{Mensagem}

O periódico Mensagem de Belo Horizonte amplia nossa visão a respeito da vida teatral fora do eixo Rio - São Paulo. Com o subtítulo de Quinzenário de Arte e Cultura, o periódico surgiu em Belo Horizonte com a direção de Guilhermino César, de 1939 a 1944. O número de matérias sobre teatro não é elevado. A contribuição do periódico fica por conta das notas e pelas entrevistas cedidas por J. Carlos Lisboa, futuro diretor do Teatro do Estudante de Minas Gerais.

As notas teatrais registram a chegada da Companhia Delorges Caminha à cidade mineira, as iniciativas do Teatro do Estudante de Minas e o sucesso das peças do autor mineiro J. Carlos Lisboa. Percebe-se que esse autor ganha grande destaque nas páginas da revista.

A imagem do Estado-Novo também é ressaltada em Mensagem. Sem indicação de autoria, a seção 'Teatros' traz a seguinte consideração (26.2.1.3):

O Estado Novo está senhor da capacidade de penetração da obra teatral na alma do povo. Por isto é que vem fazendo dele um instrumento de cultura, alimentando e amparando todos os gêneros de representação cênicos, não só com rigorosa seleção de elencos, mas também com interferência sobre o regime financeiro das companhias, a fim de que os espetáculos sejam acessíveis à média das bolsas de um país pobre.

Fica claro aqui o elogio ao Ministério da Educação que, segundo o autor, vinha, via Serviço Nacional de Teatro, contribuindo para o desenvolvimento da cena nacional, marcada pela apresentação de peças históricas e comédias de costumes.

Há também uma curiosa consideração a respeito da apresentação de Romeu e Julieta, pelo Teatro de Estudantes do Brasil, com a direção de Paschoal Carlos Magno e assistência de Itália Fausta. Sem indicação de autoria, a seção 'Teatros' (26.2.1.4) traz um artigo de análise da representação, que aponta o nível elevado da peça, incompreensível para a maior parte do público: 
Não se faz infiltração social sobre incultas massas como a brasileira, mantendo em teatro de elite uma peça de altitude literária inatingível para essa turba. É preciso que o Teatro do Estudante do Brasil compreenda isso e mude a orientação, provocando a acorrência (sic) do público com a apresentação de peças que ele seja capaz de atingir a apreciar. Sem o estágio preliminar desse teatro, teremos o fracasso do generoso e difícil trabalho dos estudantes brasileiros.

Podemos afirmar que os colaboradores da revista Mensagem apoiavam e defendiam a autoria e representação de peças que valorizassem a história brasileira e seguissem o formato das comédias para rir, rir, rir. Uma das primeiras iniciativas em se produzir um teatro mais elaborado, com uma temática mais densa e com uma preocupação cenográfica maior, foi descartada pela revista. Esses avanços propostos pelo Teatro do Estudante do Brasil não seriam compreendidos pelo público, colocado aqui como um dos responsáveis pela mesmice, monotonia e atraso do teatro nacional.

\section{Cultura Política}

Em março de 1941, entra em circulação a revista Cultura Política, órgão oficial do regime estado-novista, que se propunha a definir e estabelecer o rumo das transformações sociais e políticas do país. Buscando criar uma imagem de 'harmonia social', Getúlio Vargas adotou uma ideologia de caráter essencialmente nacionalista, disciplinou as relações entre capital e trabalho, promoveu o avanço do processo industrial e implementou leis trabalhistas, de modo a mascarar o controle e a dominação social. Assim, para penetrar nos domínios da sociedade civil, o Estado criou aparatos culturais próprios, a fim de produzir e difundir sua concepção de mundo, legitimando suas ações frente à opinião pública ${ }^{52}$.

Tendo como colaboradores importantes nomes da elite intelectual brasileira, Cultura Política traz em suas páginas artigos de naturezas diversas, abordando desde costumes e o folclore de várias regiões do país, como fatos significativos da nossa história que contribuíram para a construção de uma sociedade modelo. Entre as páginas da revista, a seção 'Teatro' tinha seu destaque, trazendo Raimundo Magalhães Júnior e Ruben Gill como principais colaboradores. Veremos de que modo eles se posicionam em relação às

\footnotetext{
52 BUMIRGH, Nádia Regina Marques Coelho. Graciliano Ramos e a Revista Cultura Política. Tese de Doutorado. São Paulo: Faculdade de Filosofia, Letras e Ciências Humanas-USP, 2003.
} 
realizações teatrais da época no capítulo 4, onde discorreremos sobre as iniciativas dos grupos amadores de teatro, entre eles o Teatro do Estudante e Os Comediantes.

Tanto Magalhães Jr. quanto Ruben Gill destacam o Serviço Nacional de Teatro como responsável pela nova direção dada à cena nacional. Ambos registram a importância de nomes como Abadie Faria Rosa e João do Rego Barros na recuperação do nosso decadente teatro e constatam a eficácia do SNT como aparelho controlador das atividades de cena naquilo que diz respeito à exploração comercial das artes e letras teatrais.

Ruben Gill, em seu artigo Teatro, de 1942 (27.3.2.12) afirma que as causas da decadência do teatro nacional devem ser atribuídas ao regime que antecedeu o Estado Novo, já que permitia a apresentação de peças "puramente recreativas". Para ele, o estabelecimento da censura teatral teve importante papel na recuperação das realizações dos palcos nacionais.

Percebe-se nesses textos que a produção cultural é vital para o desenvolvimento da nação e que sua realização está vinculada às iniciativas de um órgão do Estado, controlado por pessoas competentes que visam cultuar as tradições, harmonizando tendências diversas. Constrói-se assim mais uma forma do discurso estado-novista, que anestesiava a sociedade civil, legitimando a estratégia político-ideológica do regime.

\section{$\underline{\text { Clima }}$}

Já a revista Clima apresenta uma importante visão da produção teatral nos palcos de São Paulo, sendo Décio de Almeida Prado seu principal crítico. Em circulação na imprensa paulista de maio de 1941 a novembro de 1944, o periódico apresentou 11 números dentro da nossa data de interesse. Entre as críticas de espetáculos destacam-se: Trio em Lá Menor, de Raimundo Magalhães Jr pela Cia Roullien; O Inimigo das Mulheres, com a tradução de Carlo Goldoni pela Cia Procópio Ferreira; e Comédia do Coração, de Paulo Gonçalves pela Cia Dulcina-Odilon.

Uma outra importante contribuição do autor é o registro da chegada da Cia de Louis Jouvet a São Paulo e o resgate das origens do Vieux-Colombier, de Jacques Copeau. 
Encerramos assim a análise da matéria coletada nos periódicos pesquisados. Pudemos perceber que a natureza dos registros varia de acordo com o propósito e o ideal de cada periódico e com o momento no qual ele foi publicado. A análise desses registros revela uma importante contribuição ao estudo do teatro brasileiro e abre novos caminhos de pesquisa. Seguiremos agora para as contribuições pontuais dos principais dramaturgos, atores e companhias que ocuparam nossos palcos nas décadas de 20 e 30. 


\section{2 - O que se Promete... Companhias, Atores e Dramaturgos em Destaque}

"A tríade básica do fenômeno cênico permanece inalterada. Formam-na o ator, o texto e o público. Sem o ator, o texto lido passa à esfera da literatura. Sem o texto, o território se define como mímica ou dança. Sem o público [...] haveria um simples exercício abstrato. A presença física do ator em face de testemunhas torna-se assim, a única maneira de se entender o teatro. E sendo o ator um homem, e a palavra uma de suas prerrogativas fundamentais, o melhor uso dela acaba por distinguir o espetáculo que a contém" 53 .

Por ser o produto final de uma criação coletiva, o gênero teatral se distingue das demais manifestações artísticas. Pela mesma razão, justifica-se, em algumas hipóteses, o porquê do atraso da modernização do fazer teatral que não acompanhou as transformações pós-Semana de Arte Moderna. A tríade mencionada acima deveria evoluir na mesma velocidade e apresentar processos que demonstrassem uma finalidade em comum.

Seguindo a hipótese de que só em 1943 houve a feliz confluência dos ideais modernos na esfera do texto, da representação e da encenação na montagem de Vestido de Noiva, fica frágil na memória o que ocorreu nos anos imediatamente anteriores. No entanto, mesmo sem poder ser caracterizada como moderna, a tríade do fenômeno cênico das décadas de 20 e 30 cumpriu seu papel e estabeleceu, à sua maneira, uma produção teatral intensa e valorizada pelo público da época.

Dando continuidade ao propósito desta dissertação, nos deteremos um pouco sobre a vida teatral das décadas pesquisadas, estabelecendo como pano de fundo essa agitada produção que movia as casas de espetáculo, as companhias teatrais, os dramaturgos e a imprensa periódica especializada no assunto. Antes de avaliar intenções modernas que irromperam nos nossos palcos antes de 1943, buscaremos delinear e caracterizar o gênero

\footnotetext{
53 MAGALDI, Sábato. "Teatro Hoje e no Futuro". In: Depois do Espetáculo. São Paulo: Perspectiva, 2003. p. 05.
} 
trabalhado pelos dramaturgos em destaque, a estrutura adotada pelas companhias teatrais, os atores de renome, a comunicação com a platéia e os fatos históricos que influenciaram nessa composição.

Depois de um longo período de visitação estrangeira, o início da Primeira Guerra Mundial estabeleceu uma distância entre a produção nacional e a européia, que gerou um incentivo não apenas aos atores brasileiros, mas principalmente aos autores nacionais. Estabelecido um novo sentimento nacionalista, revigora-se o gênero comédia de costumes, sem nenhuma proposta de renovação da tradição herdada de Martins Pena.

Para terem suas peças representadas, os autores não podiam perder de vista a estrutura das companhias teatrais, estabelecidas em torno do primeiro ator, geralmente empresário e dono das mesmas. Responsável pela escolha do repertório, administração dos lucros das bilheterias e escolha do elenco, o primeiro ator deveria estar no centro de toda a produção, pois a premissa essencial era que ele brilhasse sempre. Auxiliado pelo ponto, que sussurrava suas falas, o primeiro ator se isentava até mesmo dos ensaios. "A vaidade do intérprete, em suma, coincidia com o seu interesse comercial. Identificar o artista, física e psicologicamente, conhecer-lhe os sestros, as manhas, era um prazer que não convinha negar às platéias" 54 .

Leopoldo Froes e Procópio Ferreira sabiam muito bem disso. Para eles, atender o interesse e gosto do público era prioridade absoluta. Se era a platéia que buscava diversão e se satisfazia com as peças que provocavam o riso, não havia necessidade de alteração da fórmula. O sucesso de bilheteria das comédias de costumes ia ao encontro do gosto popular.

Essa centralização e manipulação do ator-empresário em relação ao gênero escolhido e sua recusa em renovar qualquer componente de sua produção é corroborada por alguns intelectuais da época, que julgavam a massa despreparada e desinteressada de qualquer proposta que afrontasse o lema: "Rir! Rir! Rir!".

Conhecido hoje como o período da hegemonia do ator, as décadas de 20 e 30 vivenciaram uma época de domínio da rígida estrutura das companhias teatrais, estabelecida ainda sob as bases do século XIX e de uma dramaturgia sustentada pelo gênero cômico e pela submissão aos grandes empresários. De qualquer modo, a composição dessa

\footnotetext{
${ }^{54}$ PRADO, Décio de Almeida. Op. cit. p. 21.
} 
tríade gerou frutos e sucessos; autores e atores que conquistaram seu espaço na história do teatro brasileiro e ocuparam os nossos palcos em um importante momento de maturação da consciência teatral moderna.

\subsection{A Arte de Fazer Rir: os Dramaturgos em Foco}

As comédias de costumes, além de ocupar um lugar de destaque nas casas de espetáculo, ocupavam também grande parte das colunas da imprensa periódica destinadas às produções artísticas, seja como crítica de espetáculo, foto de cenas e protagonistas, notas de estréias ou publicação na íntegra em formato folhetinesco.

Determinados autores foram constantemente citados, analisados e exaltados nas matérias por nós pesquisadas; por isso acreditamos ser essencial olharmos de forma mais demorada para suas contribuições de modo a melhor compreender a importância de cada um deles. Tentamos propor uma organização cronológica dos autores e a partir dos estudos já existentes, buscamos complementar nossa análise e adicionar novas considerações ao tema.

\section{Cláudio de Souza (1876-1954)}

O médico paulista Cláudio Justiniano de Souza é responsável pela autoria de mais de trinta peças, quase todas de grande sucesso, que ocuparam os palcos nas décadas de 10, 20 e 30. Com o início da Primeira Grande Guerra, a Europa fica ainda mais distante, afastando do nosso teatro importantes nomes do teatro francês, italiano e português. Nesse momento, a comédia passou a ser um gênero comercialmente viável, principalmente aquela que retomava os procedimentos de Martins Pena e valorizava a temática nacional. Dessa forma, a partir de 1915 houve uma revalorização das comédias de costumes, que passaram a predominar principalmente no palco do Trianon, no Rio de Janeiro.

Considerado o iniciador dessa fase da evolução da comédia brasileira, Cláudio de Souza obteve grande destaque com a representação de sua peça Flores de Sombra, primeiramente em São Paulo e, a seguir, no Rio de Janeiro. Retomando a tradição iniciada por Martins Pena e consolidada por França Júnior, Cláudio de Souza volta-se para os temas 
brasileiros e para os valores nacionais, tendência esta que se estenderia por mais duas décadas, destacando nomes como Gastão Tojeiro e Armando Gonzaga.

$\mathrm{O}$ autor figura nas páginas das revistas pesquisadas tanto como autor de peças publicadas e/ou em cartaz quanto como autor e receptor de críticas a respeito do teatro nacional. Entre as peças publicadas encontramos:

- Eu Arranjo Tudo!;

- O Exemplo do Padre;

- Os Bonecos Articulados;

- Rosas de Espanha;

- O Marido Surrado e Contente;

- Um Esposo Racional

E entre as que foram encenadas, merecem destaque:

- A Escola de Mentira;

- Eu Arranjo Tudo!;

- Flores de Sombra;

- Arte de Seduzir

Como membro da Academia Brasileira de Letras, Cláudio de Souza fazia parte da Comissão Julgadora dos Concursos Teatrais, apresentando seus pareceres na maioria dos concursos. Os discursos publicados na Revista da Academia Brasileira de Letras foram nossas principais fontes para a compreensão dos procedimentos e do posicionamento de Cláudio de Souza em relação ao teatro brasileiro da época. Em seu discurso de recepção publicado em 1924 (15.4.2), o autor defende a importância do gênero-base de suas peças:

... a comédia de costumes é a que caracteriza e individualiza um teatro, a que lhe dá corpo e alma, sangue e raça, independência e personalidade. É ela que mergulha com o escafandro da análise, e os olhos agudos da sátira no mais íntimo da alma da nacionalidade, recolhendo-lhe as comoções virginais, os anseios, os sustos, as curiosidades, os sobressaltos, as alegrias, as tristezas, as núpcias, os amores, a estética íntima dos pudores, a filosofia sagrada da moral, o relicário augusto das tradições, pesando a oiro fio os amuletos de sua fé, e as flores de suas virtudes. E quando, depois 
de ter mergulhado e remergulhado, surge à tona, emergindo à luz das ribaltas, é ela quem vasa com o estilete da ironia as impurezas, os detritos, os vícios, as taras, as imperfeições e os pezes, na bem intencionada faina de purificar e engrandecer a alma de sua raça.

O gênero em questão e as qualidades de Cláudio de Souza enquanto dramaturgo eram apoiados e contestados por grupos de intelectuais do início do século XX. Havia aqueles que apontavam Cláudio de Souza como o responsável por trazer novamente aos nossos palcos o teatro brasileiro, que havia deixado de existir por muitos anos. Em seu discurso de recepção ao autor na Academia Brasileira de Letras, Alfredo Pujol faz uma apreciação de suas peças, destacando a simplicidade utilizada pelo autor em oposição às "tristes efemeridades da tristíssima alma contemporânea" que se agravaria com peças de Ibsen e Bjornson (15.4.3):

A qualidade principal de vosso teatro, sr. Cláudio de Souza, a que mais me encanta e seduz, está na seleção dos assuntos e dos caracteres. Nas vossas comédias se reflete a vida em sua realidade flagrante, mas sem a dureza implacável e fria dos seus aspectos de maldade e egoísmo, de vícios e impurezas, de perversões e covardia.

Ao comentar a peça Flores de Sombra, Alfredo Pujol destaca a importância das "criaturas simples e boas" criadas por Souza, em uma evocação comovente da família antiga, do velho lar paulista que era unido e solidário. Destaca também a ausência de complicações e convenções no enredo da peça, que "repousa somente na verdade dos caracteres e nessa piedade amorosa e enternecida que envolve as suas figuras, tocadas de divina graça".

Por ocasião da publicação dessa peça, diversos depoimentos sobre as qualidades do autor e da obra foram incluídos na edição de 1922. Entre eles, alguns membros da Academia Brasileira de Letras, além de Roberto Gomes, Eurico Sodré, Eduardo Schwalbach (comediógrafo português) e Göran Bjorkmann (escritor sueco). Merece destaque o depoimento de Coelho Neto:

Cláudio de Souza é hoje, incontestavelmente, o nosso primeiro comediógrafo. 
E ainda:

... a linguagem, sempre natural e escorreita, sem preciosismos, ornada aqui e ali, de uma expressão ou de uma construção popular e, principalmente, o dom, que só possuem os privilegiados de refletir a vida, tal como se nos apresenta, na multiplicidade dos aspectos, variando instantaneamente, na mesma situação, do sorriso para a melancolia, como em dia de claro sol, ao leve deslize de uma nuvem, tudo, por instantes, se apenumbra, para reabrir-se em seguida em claridade mais vivida.

Reforçam esse coro Medeiros e Albuquerque, Goulart de Andrade e Paulo de Magalhães que, em março de 1933 na Revista da Academia Brasileira de Letras, publica um estudo intitulado "Cláudio de Souza e a Comédia Brasileira" (15.3.2.21). Magalhães aponta as tentativas de criação de um teatro nacional e considera a peça Flores de Sombra como "a semente do único teatro brasileiro que possuímos".

Entretanto, havia contestadores isolados que se manifestavam contra as concepções de Cláudio de Souza como dramaturgo e contra suas iniciativas como homem de teatro. Este grupo foi liderado por Antonio de Alcântara Machado, que dirigia severas críticas diretamente ao autor. Seus seguidores, por muitas vezes, limitavam-se a falar do gênero comédia de costumes de uma forma mais geral, sem apontar nomes.

Alcântara Machado, um dos primeiros a exigir um teatro verdadeiramente nacional e de qualidade, defendia a idéia da "não-existência" do teatro nacional e clamava por novos autores que arriscassem sua produção em busca da forma moderna e dos tipos brasileiros. Segundo Machado, o teatro nacional somente ganharia forma quando atitudes individualistas para promoção individual cessassem.

E é com muito vigor que, em seu artigo intitulado "Questão de Vergonha", publicado em março de 1926 na revista Terra Roxa e Outras Terras (5.3.2.3), ele aponta a irrelevância da peça Flores de Sombra, classificada por ele como a "primerose da pieguice dramática indígena" (sic), e critica severamente a iniciativa de Cláudio de Souza em querer lançar em Paris uma temporada teatral brasileira: 
Companhia e originais brasileiros em Paris, Cláudio de Souza? Mas que companhia? Mas que originais? Tudo isso não existe. Ao menos para os olhos estrangeiros, gente de fora só deve pôr a vista em cima do que temos de bom. (...) Não será com As Sensitivas nem com A Jangada, nem com cousa parecida (mesmo de longe) que a cena brasileira poderá algum dia deslumbrar a Europa. Pois se tais beberagens açucaradas e aguadas mesmo aqui não agradam estômago algum!

E:

Cláudio de Souza por falta de reflexão ou vaidade quer sujeitar o Brasil a mais um ridículo desses. Eu protesto aos gritos, na ponta dos pés, gesticulando! (...) Não sei o que Cláudio de Souza está fazendo em Paris que não vai ao teatro. Porque positivamente não vai. Só desconhecendo o que há na França nesse terreno é que se pode pensar em mostrar o que há aqui. Francamente.

O assunto continua em debate por anos. No início da década de 40, Guilherme Figueiredo publica um artigo intitulado Os Clichês da Comédia Brasileira na Revista do Brasil (16.3.2.16). O autor confere tanto ao público quanto aos autores a culpa pela baixa qualidade das comédias nacionais, recheadas de clichês e mediocridade. A simbiose público-autor ocorre, pois ambos se adulam e se gostam; nenhuma das partes propõe ou provoca a outra:

Repetimos, e repetimos para não ter trabalho, sobretudo o trabalho de gerar novas emoções e novas atitudes para os artistas, tão habituados a uma determinada espécie de representação. E como não existe a capacidade de revigorar as emoções, ou plantá-las no tablado onde nunca estiveram, procuramos a leveza do 'rir, rir, rir'. Jamais ocorreu a nenhum dos nossos teatrólogos que o teatro é vida sem uma das paredes. Para eles o importante é não deixar as mandíbulas nos seus lugares, evidência do fracasso.

Assim, a simplicidade, o conservadorismo e o sentimentalismo de Cláudio de Souza eram defendidos por aqueles que viam essas características como bases de formação da comédia nacional, e criticados por aqueles que buscavam o novo, a análise profunda dos caracteres e a exploração de tipos verdadeiramente nacionais. O segundo grupo ganhou 
força a partir da década de 40, quando experimentações de cunho moderno tomaram os palcos, intensificando a crise da comédia de costumes iniciada na década anterior.

De qualquer maneira, é necessário destacar a relevância das peças de Cláudio de Souza na história do teatro brasileiro, pois, independentemente da existência de suas qualidades artísticas, elas preencheram por muitos anos os palcos nacionais, rendendo lucro às companhias e garantindo a diversão do público.

\section{Armando Gonzaga (1889-1954)}

Em sua carreira jornalística passou por diversas redações: A Noite, A Tarde, A Gazeta de Notícias, O Malho entre outros, como repórter de polícia. Em 1925, convidado a voltar à redação d'A Noite, Armando Gonzaga se encarrega da Seção Teatral, onde estabelece definitivamente sua carreira como crítico e autor teatral. Membro da A.B.I. e conselheiro perpétuo da S.B.A.T. desde 1920, Gonzaga fez parte da geração que animou o teatro brasileiro no Trianon, depois de uma fase de esquecimento e abandono. Entre seus diversos pseudônimos estavam Epanimondas, João da Montanha, João Silvestre, Lê Maitre d'Hotel e Polegar ${ }^{55}$.

Escreveu sua primeira peça em 1912, uma burleta chamada $O$ Tiro Feminino, com colaboração de César Marques e musicada por Paulino Sacramento. Mas foi em 1921, com a representação da peça Ministro do Supremo no palco do Trianon, que sua carreira como dramaturgo começou a fazer um "ruidoso sucesso". Brício de Abreu destaca as palavras de Austregésilo de Ataíde sobre a peça de Gonzaga:

O Ministro do Supremo, que está em cena no Trianon, não é uma comédia corriqueira, gênero palhaçada, das últimas que por aí apareceram, com a exploração eterna de caipira e suas burrices e temas de amor barato em fundo de quintal. É antes uma tragédia da vida moderna escrita em estilo faceto, na qual se movem tipos da educação hodierna, fatos da existência quotidiana das grandes capitais, onde os interesses levam os homens a situações falsas, de que resulta quase sempre a ruína... ${ }^{56}$.

\footnotetext{
${ }^{55}$ COUTINHO, Afrânio \& SOUZA, J. Galante. Enciclopédia de Literatura Brasileira. 2 vol. São Paulo: Global; Rio de Janeiro: Fundação Biblioteca Nacional/DNL, Academia Brasileira de Letras, 2001.

56 Apud: ABREU, Bricio. Esses Populares tão Desconhecidos. $1^{\mathrm{a}} \mathrm{ed}$. Rio de Janeiro: E. Raposo Carneiro, 1963. p. 380.
} 
Em nossa pesquisa, Armando Gonzaga figura com diversas peças, entre notas e artigos principalmente nas páginas das revistas Fon Fon, Ilustração Brasileira e Boletim da S.B.A.T. As peças citadas no acervo consultado, que ganharam destaque na avaliação dos críticos, são:

- Graças a Deus;

- Cala Boca, Etelvina;

- A Patroa;

- O Amigo da Paz;

- O Tio Salvador;

- O Ministro do Supremo;

- O Homem do Fraque Preto;

- $O$ Folgado.

Em 1925, a revista Fon Fon publica uma crítica sobre a peça Cala a Boca Etelvina (13.3.5.8), na qual ressalta as qualidades da peça de Armando Gonzaga e destaca o talento de Procópio e Ítala Ferreira nos papéis de Libório e Etelvina:

A peça que o sr. Armando Gonzaga escreveu para a companhia do Trianon é uma finíssima comédia, esfuziante de graça e cheia de situações embaraçosas, na qual Procópio Ferreira demonstra, com seu talento ascendente, nova modalidade da sua personalidade estética.

E após analisar o enredo da peça, conclui:

'Cala Boca Etelvina' é peça para figurar durante muito tempo no cartaz do teatrinho da Avenida.

Já Oscar D'Alva em sua seção intitulada 'Notas de Arte' de junho de 1933 (13.3.5.13), analisa de uma maneira mais consistente a peça A Patroa. Percebe-se um entusiasmo mais contido em suas palavras: 
Pelo resumo vê-se que se trata de uma comédia como há muitas: nada tem de extraordinário como trama e como fundo, mas nem por isso deixa de ser uma peça digna de ser vista e aplaudida. Toda ela se desenvolve naturalmente com a vida que idealiza. Só nos pareceu que deveria ser mais preparado o desfecho da intriga. A precipitação final deu à peça mais a forma de farsa que de comédia. Mas isso talvez seja mais dentro da nossa visão que do trabalho do A., em nada tira o valor da obra. São palpitantes de ver todos os tipos.

Os críticos posteriores ao período destacam que a vasta produção teatral de Armando Gonzaga enquadra-se naquela de caráter tipicamente do século XIX, com tramas e cenas fixas, permitindo que os primeiros atores, como Leopoldo Froes e Procópio Ferreira, se tornassem ídolos populares, projetando suas personalidades sobre um esboço apresentado pelo autor. Sábato Magaldi nos aponta que:

$\mathrm{O}$ que distinguia fundamentalmente esse gênero de teatro daquele que se formou nas décadas posteriores era a ausência do diretor, incumbido de coordenar o espetáculo numa visão unitária. A improvisação de efeitos cômicos, o gosto dos 'cacos', o desequilíbrio do conjunto, não organizado em verdadeira equipe, contribuíam para situar sempre em primeiro plano a figura do astro, senhor absoluto do palco. Muitos autores passaram a alimentar as características mais brilhantes dos chefes de companhia ${ }^{57}$.

E com certeza, Armando Gonzaga era um deles.

\section{Cardoso Menezes (1878 - 1958) e Carlos Bittencourt (1888 - 1941)}

Frederico Cardoso de Menezes e Souza foi um dos maiores revistógrafos de sua época. Nascido em uma família de artistas - literatos, dramaturgos e músicos - estreou com a mágica Comes e Bebes em 1905. Depois se aliou a Chiquinha Gonzaga e mais tarde a Carlos Bittencourt na produção de inúmeras revistas, burletas e operetas que ficaram como modelo no gênero.

Brício de Abreu, em seu livro Esses Populares tão Desconhecidos, destaca que para produzir tantas revistas de êxito:

\footnotetext{
${ }^{57}$ MAGALDI, Sábato. Panorama do Teatro Brasileiro. 4 ed. São Paulo: Global, 1999. p. 195.
} 
Era preciso ser excelente poeta, humorista, ter um sentido crítico apurado, conhecer profundamente os usos e costumes da cidade, a sua política etc. Eram assinadas por grandes nomes da nossa literatura. Sua influência era tal sobre o público, que as músicas de carnaval vinham desses teatros de revistas para a rua ${ }^{58}$.

Para ele, Cardoso de Menezes, antigo presidente da S.B.A.T., era um 'tabu' no nosso teatro popular; rara peça sua não ia ao 'centenário de representações'. Grande parte de suas peças foi escrita com seu parceiro Carlos Bittencourt, que iniciou sua carreira com uma peça, inicialmente recusada por diversas companhias, mas que constituiu grande sucesso naquela época: Forrobodó, com Luiz Peixoto e Chiquinha Gonzaga.

Em nossa pesquisa, a dupla ocupa as páginas da revista Fon Fon e do Boletim da S.B.A.T. com notas e críticas sobre as revistas de sucesso em cartaz no Carlos Gomes, João Caetano entre outros. Entre suas revistas estão:

- Agüenta Felipe!;

- Meu bem, não Chore;

- Sol Nascente;

- Se a Moda Pega;

- Flá Flú;

- Para Todos;

- Conheceu Papudo!

Em 1922, a revista Fon Fon destaca o enorme sucesso da revista Agüenta Felipe! que se aproxima das 500 representações. Já em novembro de 1926, o mesmo periódico publica fotos de cenas da revista Sol Nascente, com co-autoria de Victor Pujol, apoio do empresário Manuel Pinto e a estrela Margarida Max (13.5.32).

Gênero antigo, o Teatro de Revista sofreu uma série de transformações até atingir o formato que desembarcou no Brasil, onde se transformou novamente para adquirir um caráter autenticamente nacional, cuja estrutura e convenções absorveram a cor local e o

${ }^{58}$ ABREU, Brício de. Op. cit. p. 249 
popular. Neyde Veneziano define o teatro de revista como um gênero para fazer rir e, por conseguinte, para criticar:

O ridículo é, de fato, a matéria-prima da revista. Dele ela sempre se nutriu, ao longo de sua evolução histórica. Contudo, a farsa é seu parente mais próximo, pois, ao aproximar-se do burlesco, chega à exacerbação do próprio ridículo. Mesmo como uma mistura de musical e comédia (farsa), fragmentado como chegou aos nossos dias, o gênero não foge de uma estrutura pré-estabelecida, cujo significado está implícito na própria denominação: re-vista, re-visão ${ }^{59}$.

Além das realizações da dupla Cardoso de Menezes e Carlos Bittencourt, registramos também em nossa pesquisa algumas contribuições para o gênero, como a visita de duas importantes companhias de revistas estrangeiras: a francesa Ba-ta-clan, dirigida por Madame Rasimi e com a vedete Mistinguett, e a espanhola Companhia Velasco, que incrementaram a féerie, marcada pelo luxo e pela fantasia. Entre as peças em cartaz registradas em nosso índice, 17 revistas ganham destaque. Entre os autores estão Luiz Peixoto, Bastos Tigre, Patrocínio Filho, Jardel Jércolis, Marques Porto, Luis Iglesias e Alfredo Júnior.

Gênero em alta, a revista ocupou um importante espaço nos palcos nacionais nas primeiras décadas do século XX. Ao lado das comédias ligeiras e de costumes, tinha representantes de renome, que conseguiram grande sucesso nas bilheterias do teatro comercial.

\section{Gastão Tojeiro (1980-1962)}

O carioca Gastão Tojeiro, além de fazer parte da fundação da Sociedade Brasileira de Autores Teatrais em 1917, figurou nos palcos e nas páginas das revistas das décadas de 20 e 30 como comediógrafo preocupado com os temas brasileiros, mesclando a comédia de costumes com a reivindicação dos valores nacionais. Em suas peças predomina "a sátira aos hábitos característicos da nossa organização social e política, aliada à idéia de que,

\footnotetext{
${ }^{59}$ VENEZIANO, Neyde. O Teatro de Revista no Brasil: Dramaturgia e Convenções. Campinas: Editora da Unicamp, 1991. p. 87.
} 
apesar de tudo, o Brasil é o melhor país do mundo e aqui se encontram as possibilidades futuras" 60 .

Nas páginas das revistas por nós pesquisadas, são destacadas as seguintes produções do autor:

- O Modesto Filomeno;

- Onde Canta o Sabiá;

- Zezé Cortou os Cabelos;

- É a tal do Telefone;

- A Garota dos Bons-Bons;

- A Mulata do Cinema;

- O Simpático Jeremisas;

- Faze o que eu Digo;

- A Mão Negra;

- Minha Sogra é da Polícia;

- O Homem Mosca.

Grande parte das notas e das críticas sobre suas peças está registrada no periódico Fon Fon. Uma nota importante publicada em 1922, sem indicação de autoria, destaca o promissor sucesso da peça $O$ Modesto Filomeno (13.2.1.6):

O Modesto Filomeno não pode deixar de fazer sucesso. Como n'O Simpático Jeremias, que deu mais de duzentas representações seguidas, o herói da peça tem o nome precedido de um adjetivo qualificativo. Se $O$ Simpático Jeremias com aquele adjetivo e uma época de menos interesse do público pelo teatro fez dois centenários, $O$ Modesto Filomeno fará, pelo menos, quatro. É infalível.

É curioso observar que a citação acima nos leva a entender que em 1918, época em que foi escrita e encenada a peça $O$ Simpático Jeremias, as pessoas se interessavam menos pelo teatro, ao contrário de 1922, data de estréia de O Modesto Filomeno. Um outro artigo publicado em Fon Fon faz uma crítica à peça agora já em cartaz. Repleto de elogios e palavras de exaltação, o autor da crítica (não indicado) afirma que (13.3.5.2):

${ }^{60}$ ABREU, Bricio de. Op. cit. p. 192. 
E não há exagero nesse nosso engraçadíssimo. O novo original de Gastão Tojeiro, esse $O$ Modesto Filomeno, que a Empresa do Trianon montou com aquele seu reconhecido escrúpulo, pode ser colocado ao lado daquelas peças que a gente de teatro denomina interessantemente: fábrica de gargalhadas. O público riu a bom rir. E que público! Um público distinto, a elite carioca que é habituée das primeiras do elegante teatrinho, o que faz com que essas primeiras assumam a importância, não só de acontecimentos artísticos como mundanos.

Fica claro nessa passagem o tipo de público que costumava freqüentar as sessões do Trianon. E é para essa elite que Tojeiro desenvolvia seus enredos engraçadíssimos. Neste caso, a história girava em torno da criação de um novo remédio - ortonasal - que embelezava até o mais horripilante dos narizes. Com receio de sua criação, o médico Aldomiro lança seu produto em nome de seu modesto empregado Filomeno, que passa a ganhar reconhecimento e dinheiro em seu lugar. Em uma outra passagem da crítica de Fon Fon, encontramos o grande reconhecimento dado ao elenco da peça:

Gastão Tojeiro, em torno desse fio de enredo, colocou, com rara habilidade, cenas de grande comicidade, coordenadas com a maestria que todos the admiram; ele, um admirável conhecedor da carpintaria teatral. Mas, se Tojeiro escreveu uma peça interessante, teve a felicidade de encontrar intérpretes à altura de seu trabalho. Leopoldo Froes, no Filomeno, foi inexcedível, fez uma verdadeira criação. Não sabemos se é este o papel a que ele mais brilho deu.

Além de Leopoldo, os elogios também se destinam a Arthur de Oliveira no papel do médico Aldomiro, a Jaime Costa, Plácido Ferreira, Teixeira Pinto, Norberto Teixeira e Estevam Santos no elenco masculino. Entre as mulheres, destaque para Belmira de Almeida, Amada Fonfredo, Palmira Sieva, Amélia de Oliveira e Elvira Mendes.

Dois anos depois - em 1924 - é publicado na revista Mundo Literário o ante-ato da peça Faze o que Digo, representada pela primeira vez no Teatro Carlos Gomes (20.1.4). 
Com a autoria de mais de cem peças, Gastão Tojeiro exalta valores nacionais por meio de enredos simples e intrigas banais que se enquadravam nos perfis dos primeiros atores, que atingiam grande sucesso principalmente nos palcos do Trianon.

\section{Viriato Correa (1884-1967)}

Dramaturgo, jornalista, historiador e empresário teatral, Viriato Correa deu sequiência à produção de comédias de costumes agora em concorrência com algumas tentativas de renovação. Destacou-se pelo grande número de comédias de ambiente tipicamente carioca e com algumas representações históricas de célebres figuras brasileiras ${ }^{61}$.

Os principais periódicos que publicaram notas, artigos e/ou críticas a seu respeito foram Fon Fon, Leitura para Todos, A Cena Muda e o Boletim da S.B.A.T. Entre as peças em cartaz anunciadas nessas revistas estão:

- A Juriti;

- Zuzu;

- A Sertaneja;

- Bicho Papão;

- Marquesa de Santos;

- Tiradentes;

- Carneiro Batalhão

Além de suas peças, destacamos também duas importantes iniciativas do autor para o desenvolvimento do teatro nacional: o concurso Alvorada dos Novos e a Empresa Viggiani \& Viriato. A primeira busca incentivar novos dramaturgos nas montagens de suas peças e na correção de eventuais problemas no texto:

Alvorada dos novos é o nome de uma iniciativa com a qual Viriato Correa pretende atrair à literatura teatral escritores novos que não tenham estreado ainda e deste modo incentivar os tímidos que, temerosos de que as empresas não lhes montem as suas produções, não se apresentam. Viriato promete-lhes ler com carinhos os seus originais e todos aqueles que conquanto mesmo não sejam o de 'perfecto' (sic) e que não

${ }^{61}$ CACCIAGliA, M. Pequena História do Teatro no Brasil. São Paulo: T. A. Queiroz: EDUSP, 1986. p. 103. 
preencherem os requisitos para a montagem, terão indicações do conhecido e autorizado escritor que lhes indicará as correções necessárias após as quais dará montagem (13.2.1.8)

A segunda diz respeito à formação de uma empresa teatral que subsidie e forme companhias para ocupar teatros e realizar montagens de sucesso. Uma nota publicada nas páginas de Fon Fon em 1923 destaca a organização de uma companhia para ocupar o Teatro Boa Vista em São Paulo. O diretor artístico Viriato Correa fez uma seleção entre as peças de maior sucesso nos palcos do Trianon para levar aos palcos paulistanos. Entre elas estão: Zuzu, do próprio autor; O Tio Salvador, A Flor dos Maridos e O Mimoso Colibri, de Armando Gonzaga; O Pobre Milionário, O Modesto Filomeno e Os Rivais de George Walsh, de Gastão Tojeiro; A Escola de Mentiras, de Cláudio de Souza; E o Amor Venceu, de Paulo de Magalhães entre outras (13.2.1.14)

Durante o regime do Estado Novo, entram em cena as representações históricas de grandes nomes do nosso passado. Um novo discurso passa a vigorar nos palcos nacionais subsidiados pelo governo e nas instituições com finalidades artísticas. A partir do final da década de 30, Viriato Correa dedica-se à elaboração de peças desse gênero, como $A$ Marquesa de Santos, de 1938, e Tiradentes, de 1941.

\section{Abadie Faria Rosa (1889-1945)}

Ainda dentro da linha do teatro de costumes, encontra-se um outro autor de sucesso durante das décadas de 20 e 30: Alexandre Abadie de Faria Rosa. Natural de Pelotas (Rio Grande do Sul), foi dramaturgo, tradutor, presidente da Sociedade Brasileira de Autores Teatrais e diretor do Serviço Nacional de Teatro.

Seu nome figura principalmente nas páginas das revistas Fon Fon, Revista Brasileira, Mundo Literário e Dom Casmurro. Na primeira, aparece em notas e em entrevistas, como a notificação da estréia da Companhia Oficial de Comédia Brasileira em 1932 (13.2.1.20):

Terá início, no próximo dia $1^{\circ}$, a temporada oficial de comédia brasileira que o artistaempresário Jaime Costa vai realizar no teatro João Caetano, com o apoio da Prefeitura do Distrito Federal, obtido graças à boa vontade do ilustre interventor Adolfo Bergamini. Os artistas com que Jaime Costa formou o elenco de sua companhia são 
figuras de prestígio no nosso meio teatral, o que constitui uma garantia segura do êxito dessa temporada que se aguarda com entusiasmo. A peça de estréia será a comédia $A$ Estrada dos Deuses, do autor brasileiro Abadie Faria Rosa, um vitorioso nas letras teatrais.

Outras peças em cartaz que destacamos em nossa pesquisa são:

- Longe dos Olhos;

- D. João André;

- Meu Amor;

- Nossa Terra

- Elas (escrita com Luis de Barros);

- Vinhas do Senhor (escrita com Renato Lacerda)

Na Revista Brasileira, há a publicação de uma nota sobre a Temporada de Comédias sob a direção de Faria Rosa (23.1.1.4). Entre as comédias ligeiras programadas estão: Amor não Envelheceu e Três Meninas da Casa.

Já na revista Mundo Literário, Faria Rosa ganha espaço como crítico teatral, tendo dois de seus artigos publicados: Teatro (20.3.2.1), sobre o insucesso da temporada oficial da prefeitura em 1922 e João do Rio, Escritor de Teatro (20.3.4.4), no qual o autor apresenta um retrospecto da vida e da obra de João do Rio.

Como diretor do Serviço Nacional de Teatro no final da década de 30 e início de 40, Faria Rosa passa a ser alvo de severas críticas nas páginas de Dom Casmurro. Em um artigo intitulado $O$ Grande Escândalo do Serviço Nacional de Teatro, o diretor é acusado de não ter incluído a Companhia Dramática Brasileira no programa de subsidiados por Gustavo Capanema por razões de interesses pessoais (24.3.2.44). Meses depois um outro artigo critica a atitude do diretor em não ter comparecido à estréia da peça Pertinho do Céu, de José Wanderley e Mario Lago pela Companhia Delorges Caminha no Carlos Gomes. O autor afirma que a presença do diretor do S.N.T. em estréias de peças subvencionadas pelo governo é obrigatória (24.3.2.45).

Brício de Abreu e Raimundo Magalhães Júnior engrossam o coro dos oponentes de Abadie Faria Rosa. Em um artigo intitulado Suicídio Abadiniano! (24.3.2.47), Brício discute a estranheza dos críticos em relação à escolha da nova peça a ser representada pela 
Companhia Procópio Ferreira no Serrador: Suicídio por Amor, de Faria Rosa. Por ser uma peça de autoria do próprio diretor do S.N.T. levanta-se a hipótese de haver sido uma imposição do mesmo sobre a companhia.

Raimundo Magalhães Jr. oficializa a suspeita acima e endereça uma denúncia contra o diretor do S.N.T a Getúlio Vargas, publicada nas páginas de Dom Casmurro (24.3.2.49). $\mathrm{O}$ autor afirma que as companhias estão sendo obrigadas a montar peças da autoria de Faria Rosa como Suicídio por Amor, Levada da Breca, Crepúsculo e Longe dos Olhos.

Brício de Abreu retoma suas críticas fazendo um Apelo aos Artistas!! (24.3.2.49). Além de reforçar as críticas feitas ao diretor do S.N.T., o autor também apresenta idéias que poderiam gerar frutos ao teatro nacional:

Se o Serviço Nacional de Teatro, em vez de encher os cofres dos donos dos edifícios, amigos do sr. Abadie, tivesse construído em cada bairro da cidade um teatro - em cada grande cidade do Brasil também um ou dois teatros, obtendo o livramento dos impostos para essas casas e as companhias que nelas trabalhassem, pelo menos alguma coisa teria ficado em proveito dos nossos artistas e do nosso teatro. Isso é o mínimo que nos ocorre, porque há muitas outras idéias úteis por aí que o sr. Abadie seria incapaz de ter.

Nota-se que a direção do Serviço Nacional de Teatro não foi uma época tranqüila na vida de Abadie Faria Rosa. Envolvido por uma série de questões políticas, foi alvo de severas críticas por parte dos artistas e intelectuais que passaram a vê-lo não mais como um colega de profissão, mas como um obstáculo na constituição de um teatro nacional com subsídios justos e investimentos adequados.

\section{Oduvaldo Vianna (1892 - 1972)}

Empresário teatral, jornalista, escritor, contista, rádio-dramaturgo e cineasta, Oduvaldo Vianna reúne em seu repertório, além de diversas comédias feitas sob medida para o público da época, 255 novelas radiofônicas - gênero por ele introduzido no Brasil em 1940 - e 3 filmes. Foi diretor da Companhia Brasileira de Comédias Abigail Maia juntamente com Viriato Correa e Nicolino Vigiani na década de 20 e autor em destaque das Companhias Procópio Ferreira e Dulcina-Odilon.

Nas páginas das revistas aqui pesquisadas, destacam-se as seguintes peças: 
- Amor;

- A Canção da Felicidade;

- Feitiço;

- A Última Ilusão;

- Terra Natal;

- Os Girassóis;

- A Dama da Lua (em parceria com Affonso Schmidt);

- Manhãs de Sol;

- O Vendedor de Ilusões;

- O Alemãozinho;

- O Castagnaro da Festa;

- O Homem que Nasceu duas Vezes.

As notas e artigos da revista Fon Fon trazem as estréias e as peças do autor que estavam em cartaz na época. Seja na inauguração do Teatro Rival com a peça Amor pela Companhia Dulcina-Odilon em março de 1934 (13.2.1.24), seja com a nota de Oscar D’Alva sobre a opereta A Dama da Lua escrita em parceria com Affonso Schmidt em maio de 1933 (13.3.5.11).

Já a revista Frou Frou apresenta um importante texto sobre o autor, intitulado "Oduvaldo Vianna - Autor, Empresário, Ensaiador e Ator" (21.3.4.7) - um panorama da vida artística do autor, que pretendia criar um teatro de comédias no Brasil, o Teatro Pedro II, que seria inaugurado com a peça A Marquesa de Santos, de Luís Edmundo.

Saul de Weston, na Revista Brasileira de setembro de 1934, aponta o caráter moderno da peça Canção da Felicidade, comédia representada num palco dividido em três espaços cênicos. Tão logo termina uma ação num espaço a cortina se fecha e a ação se inicia em outro. Isso proporciona ao espectador uma visão de conjunto e "dá ao teatro um pouco da técnica do cinema" (23.3.5.1). É importante relembrar que a peça Amor, também de Oduvaldo Vianna, de 1933, apresentava o mesmo recurso, com o palco dividido em cinco espaços cênicos. Lembre-se que essa divisão do palco em espaços cênicos será retomada por Nelson Rodrigues na composição de Vestido de Noiva, em 1943, mas com a agilidade da iluminação dos planos. 
Sylvia Moncorvo, crítica da revista A Cena Muda, aponta as qualidades da atriz Gilda Abreu no filme Bonequinha de Seda, de Oduvaldo Vianna em setembro de 1941 (18.3.4.1).

Contrário à posição de críticos como Antonio de Alcântara Machado e a um grande número de estudiosos que apontam o vazio do teatro brasileiro nas décadas iniciais do século XX, Wagner Madeira, em seu estudo sobre a vida e obra de Oduvaldo Vianna, aponta as qualidades e também os problemas da literatura dramática produzida pelo autor e destaca sua importância para a história do teatro nacional:

De marcante visão empresarial, contribuiu para a expansão do teatro brasileiro para outros centros, a começar por São Paulo, estendendo-se para o interior paulista e outros estados, como Minas Gerais e Rio Grande do Sul. Nesse sentido, foi pioneiro em uma excursão estrangeira, quando em 1923 levou o que de melhor se fazia em termos de teatro para o Uruguai e Argentina, fazendo conhecida a dramaturgia brasileira, o que promoveu um intercâmbio sem precedentes até então. Vislumbrou logo cedo as infinitas possibilidades do cinema e as fez contribuir para o teatro, implantando o sainete brasileiro como tentativa de unir as duas linguagens. Colocou no palco o divórcio, a partir de 1920, ampliando a discussão de tema tão polêmico para a época, em linha indiscutivelmente progressista. Desde sempre um defensor do teatro brasileiro, nacionalista convicto que era, soube se renovar a partir do início da década de 30, praticando um teatro de ambições mais cosmopolitas, universais, em produções como $O$ Vendedor de Ilusões e Feitiço. Para tanto, o aprendizado foi longo e persistente, se afirmando em experimentações formais de palcos subdivididos e cenas simultâneas, que se não foram bem sucedidas em Ai se Melo! e Mas que Mulher!, redundaram em pleno êxito em Amor, de $1933{ }^{62}$.

Oduvaldo Vianna obteve grande sucesso nos palcos tanto como autor quanto diretor nas primeiras décadas do século XX. Suas produções sempre tiveram espaço no noticiário e nas colunas críticas dos periódicos que circulavam na época. Com certeza, ele ocupa, juntamente com os outros autores aqui mencionados, um lugar de destaque no panorama do teatro nacional.

\footnotetext{
${ }^{62}$ MADEIRA, Wagner Martins. Formas do Teatro de Comédia: A Obra de Oduvaldo Vianna. Tese de Doutorado. São Paulo: FFLCH-USP, 2003. p. 233.
} 


\section{Paulo Gonçalves (1897 - 1927)}

Representante do teatro alegórico e simbolista da virada do século XIX para o XX, Paulo Gonçalves foi também poeta, jornalista e professor, falecido com apenas 30 anos de idade. Sua peça de estréia, a comédia 1830, ocupou por diversas vezes as notas das revistas aqui pesquisadas. Com um elenco de primeira - Apolônia Pinto, Abigail Maia, Margarida Max, Procópio Ferreira, Palmerim Silva entre outros - a peça de 1923 reconstituía a vida em São Paulo nos anos 30 do século XIX. "As brincadeiras dos estudantes vencem às vezes o mal-estar dos versos, e a sua boa índole não admite que um escravo seja vergastado. Há um pouco de má oratória sobre a fibra da mulher paulista, e a comédia termina pelo melhor: o estudante pobre, mas sincero e honrado, recebe o consentimento para casar-se com a moça rica"63.

O periódico Fon Fon registra, em abril de 1923, a preparação da Companhia Brasileira de Comédia Abigail Maia, dirigida por Oduvaldo Vianna, para encenar a peça 1830 (13.5.15). Um ano depois, essa mesma peça participa do concurso da Academia Brasileira de Letras e é declarada vencedora com os seguintes argumentos (15.3.2.2):

O tema de 1830 é um idílio em São Paulo, no tempo que o título diz ser o do romantismo. $\mathrm{O}$ autor, poeta, trata-o carinhosamente em verso, adotando por modelo a graciosa maneira de Rostand. Sente-se, por vezes, como na cena do balcão de Cyrano de Bergerac, que alguém sopra ao poeta, senão as idéias e as imagens, ao menos a disposição das cenas e o ritmo dos versos. É um inspirador que sugere, não um 'ponto' que dita. E a obra de Paulo Gonçalves, ainda que vestida pelo figurino de Cyrano, tem vida própria, move-se por si e com calor natural. É uma peça leve e encantadora, flor desabrochada num vaso de tradição. É uma filigrana literária que se lê com prazer e que se acompanha na cena com enlevo e saudade das almas que se foram nos dias do passado. É teatro de arte e teatro para ser visto e no palco, que é o seu ambiente, avulta em grandeza e rebrilha.

Outra peça do autor em destaque nas páginas das revistas consultadas é A Comédia do Coração. Ela também participa do concurso da Academia do ano de 1928, mas perde o

\footnotetext{
${ }^{63}$ MAGALDI, Sábato. Op. cit. p. 189.
} 
prêmio para a comédia Gente Sensível, de Jarbas de Carvalho (15.3.2.12). Ela estréia o Caderno Especial publicado por Dom Casmurro, no qual eram publicadas peças de sucesso de autores nacionais (24.1.8) e é representada pela Companhia Dulcina-Odilon nos palcos do Teatro Regina em São Paulo nos anos de 1941 e 1942 (18.2.1.6. e 28.3.2.2).

\section{Paulo de Magalhães (1901 - 1972)}

Carioca nascido em 22 de janeiro de 1901, Paulo de Magalhães foi poeta, romancista, jornalista e compositor; mas foi como teatrólogo que ele obteve mais destaque. Autor de diversas peças de sucesso das décadas de 20 e 30, membro da Academia Carioca de Letras e vice-presidente da Sociedade Brasileira de Autores Teatrais.

Nos periódicos pesquisados, Paulo de Magalhães aparece principalmente nas páginas de Fon Fon, Boletim de S.B.A.T. e Dom Casmurro. Suas peças alcançaram o sucesso principalmente com a Companhia Procópio Ferreira no palco do Trianon. Entre as peças que ficaram em cartaz, localizamos as seguintes:

- Velhice Desamparada;

- E o Amor Venceu... ;

- Senhora Futilidade;

- Aluga-se uma Mulher;

- Flor da Rua;

- Guerra às Mulheres;

- O Querido das Mulheres;

- Felicidade;

- O Marido da Estrela;

- Estação da Luz;

- Coração não Envelhece;

- A Flor da Família.

Pelo concurso promovido pela Academia Brasileira de Letras, destacamos:

- As Aventuras de um Rapaz Feio, no concurso de 1926;

- O Coração não Envelhece, no concurso de 1931; 
- O Interventor, no concurso de 1932.

As notas teatrais da revista Fon Fon sempre traziam informações sobre as estréias de suas peças no Trianon e fotos do autor com os intérpretes de suas peças (ver 13.5.28, 13.5.33 e 13.5.35). Em maio de 1939, o periódico publica um curioso artigo escrito pelo próprio autor, intitulado A Sua PRA apresenta: Paulo de Magalhães por ele mesmo...(13.3.4.13). Por meio dessa síntese autobiográfica, descobrimos o lado supersticioso do dramaturgo, que confiava sua sorte ao número 11 :

Nasci às 11h do dia 22 de janeiro de 1901 (cuja soma é 11) na casa número 33 da Rua dos Arcos, aqui no Rio. Como se vê, a influência do número 11 e seus múltiplos é decisiva na minha vida desde o princípio... A minha cadeira na Academia Carioca de Letras é número 11, assim como a da de Conselheiro-Vitalício da Sociedade Brasileira de Autores Teatrais. Já possuí 11 automóveis até hoje, e a soma de número da placa do meu atual "V-S" é 11... Chamo-o o meu "V-11" porque, somando, a gente "Vê 11"... Entrevistei em Roma e recebi benção do Papa Pio XI num dia 11 de novembro, décimo primeiro mês do ano... A minha primeira peça "O Amor Venceu..." foi estreada no dia 11 de janeiro, tinha 11 letras no título e 11 personagens em cena. A minha última peça estreada festejou centenário no dia 11 próximo passado (sic) e tinha também 11 personagens: - "A Flor da Família" cujo título primitivo foi "Titio Dondon”, com 11 letras, interpretada pelo $1^{\circ}$ ator que, legalmente, se assina Jaime B. Costa... 11 letras!

Depois de escrever muitas comédias de sucesso, Paulo de Magalhães é promovido à vice-presidência da Sociedade Brasileira de Autores Teatrais. Na década de 40, passa a exercer suas funções de vice e passa a sofrer duras críticas por seus atos. O hebdomadário Dom Casmurro registra em suas páginas a principal polêmica em torno do nome de Paulo de Magalhães. Brício de Abreu, principal crítico teatral do periódico em questão, acusa-o de colocar suas preferências pessoais acima das questões profissionais, o que estaria prejudicando importantes trabalhos dos artistas nacionais. Jaime Costa, proibido pela S.B.A.T. de representar peças de autores associados por supostamente se intitular autor das peças quando na verdade não o era, publica uma matéria raivosa e cheia de insultos aos membros e à direção da Sociedade. Em junho de 1941, no artigo intitulado "O Caso Jaime 
Costa e a S.B.A.T.” (24.3.2.60), Brício apresenta duas opiniões diversas sobre o caso. A primeira é do também autor e crítico Raimundo Magalhães Júnior:

Jaime Costa tem $50 \%$ de razão. Que na S.B.A.T. há autores semi-analfabetos, é verdade. Há muitos que não escrevem chuva, por hesitarem sobre se é com "ch" ou "x"... Mas há outros que não o são e nesse ponto Jaime Costa foi injusto. A S.B.A.T., defendendo os autores que são realmente autores, fez bem. Mas esmagando Jaime Costa - ou pensando esmagar - fez mal.

E do vice-presidente Paulo de Magalhães:

Mas neste lamentável caso, a S.B.A.T. tem razão integral. Foi agredida, violenta e injustificadamente, pelo citado autor em termos altamente ofensivos a todos os autores: nacionais e estrangeiros. Muito simplesmente se resolverá o caso: Jaime Costa - ou alguém por ele autorizado - deve pedir reconsideração do ato da S.B.A.T. para que, reaberta a questão, seja encontrada uma fórmula conciliadora.

Percebemos com as matérias publicadas ao longo da década de 40 que, o sucesso alcançado por Paulo de Magalhães nas décadas anteriores é agora substituído por críticas e desentendimentos originados dentro da própria comunidade teatral. Suas qualidades de dramaturgo renderam-lhe melhores frutos do que as de diretor da S.B.A.T.

\section{Joracy Camargo (1898 - 1973)}

Formado no Teatro de Brinquedo de Álvaro Moreyra, Joracy Camargo começou como ator e autor de revistas até encontrar um espaço como autor de comédias, atingindo a fama com Deus lhe Pague em 1932. Assim como essa peça, muito de seu repertório foi feito 'sob medida' para o ator Procópio Ferreira.

Entre as peças que aparecem em nossa pesquisa estão:

- Calma no Brasil;

- Ciranda-Cirandinha;

- Choffeur;

- Aleluia; 
- O Bobo do Rei;

- Maria Cachucha;

- Fora da Vida;

- O Sábio;

- A Proclamação da República;

- O Burro;

- Sindicato dos Mendigos;

- Reconstituição Teatral Radiofônica da Última Fase da Independência Nacional;

O autor ganha espaço nas páginas de Dom Casmurro não apenas nas notas e ilustrações, mas também no especial Caderno de Teatro, que publicava mensalmente peças consagradas de autores nacionais. Dessa forma, a peça $O$ Burro foi a $\mathrm{n}^{\circ} 02$ publicada em março de 1942 (24.1.9) e Sindicado dos Mendigos a nº 07 (24.1.14).

Em março de 1940, o mesmo hebdomadário publicou uma nota sobre a inauguração do Teatro Serrador pela Companhia Procópio Ferreira com a peça Maria Cachucha, em conformidade com o S.N.T. em sessões às 16, 20 e 22 horas. Um mês depois - abril de 1940 - Dom Casmurro publica uma crítica de Ricardo Pinto originalmente publicada no Diário de Notícias, intitulada "Uma Cadeira Vazia" (24.3.4.16). A crítica apresenta o inconformismo do autor com a não eleição de Joracy Camargo para a cadeira de número 4 do Conselho da S.B.A.T.; Freire Filho, também inconformado, disponibiliza sua própria cadeira àquele que considera o "maior autor teatral brasileiro".

Apesar de haver notas e indicações de diversas produções do autor, é com a peça Deus the Pague que Joracy Camargo consegue maior destaque. Entre essas publicações, separamos a crítica de Edson Carneiro, publicada nas páginas do Boletim de Ariel em janeiro de 1934 (22.3.5.3). O nome da crítica leva o nome da peça, que segundo Carneiro é a primeira peça de um autor nacional que aborda os problemas imediatos do Brasil, "dando ao teatro brasileiro um caráter social até então desconhecido".

Alcançando imensa popularidade, essa peça pode ser considerada como um dos marcos da dramaturgia brasileira. Apontada por alguns como iniciadora do "teatro social brasileiro", ela apresenta a idéia do "mendigo milionário" e suas alusões políticas deixam 
claro seu parentesco com a peça com Adão, Eva e Outros Membros da Família..., de Álvaro Moreyra.

Décio de Almeida Prado, em uma visão crítica um pouco mais distanciada, aponta que para o teatro brasileiro do início da década de 30 , alheio quase que totalmente ao que se passava no teatro universal, alheio à figura do encenador, aos repertórios que iam além das pecinhas de costumes nacionais e as comédias de baixa comicidade, Deus lhe Pague tinha mesmo que "repercutir como uma bomba: possuía um fundo mais sério, apresentava certos problemas sociais e políticos, fazia pensar, e era escrito de forma extremamente acessível, a que não faltava inteligência. $\mathrm{O}$ grito de 'obra-prima' surgiu espontaneamente de todos os lados",64.

Ao progredir rumo a modernização ao longo da década de 40, o teatro brasileiro foi tendo contato com autores e obras e produzindo peças que banalizaram o virtuosismo de Deus lhe Pague. Tanto a idéia da peça quanto seu êxito estavam presos ao seu momento de origem, já que enquanto literatura dramática a peça não se sustentou.

Numa análise literária, contudo, nada sobra de Deus lhe Pague. Reconhecemos-lhe o mérito de haver trazido pela primeira vez, o nome de Marx. A crítica à ordem burguesa correspondia a um anseio que se polarizaria, logo depois, nos movimentos de esquerda e de direita. Joracy Camargo vinha satirizar a filantropia estabelecida, de porta de igreja. O impacto provocado pelo tema deve ter garantido o êxito inicial, que depressa se fez prestígio permanente. A aceitação da peça não impede que ela nascesse de um lugar-comum, se nutrisse de frases feitas e desembocasse em subfilosofia ${ }^{65}$.

Assim, a peça de Joracy Camargo teve seu lugar de destaque na história do teatro brasileiro da década de 30; entretanto, pela ausência de qualidades dramáticas consistentes, não marcou seu lugar na história da literatura brasileira. De qualquer forma, fica aqui o registro de uma das peças de maior êxito nos palcos nacionais na época em questão.

\footnotetext{
${ }^{64}$ PRADO, Décio de Almeida. Apresentação do Teatro Brasileiro Moderno. São Paulo: Perspectiva, 2001. p. 46.

${ }^{65}$ MAGALDI, Sábato. Op. cit. p. 201.
} 


\title{
2.2. Os Mágicos da Cena: as Companhias e seus Astros
}

Como já vimos anteriormente, as companhias teatrais da época em questão se organizavam em torno do primeiro ator e empresário que ditava as regras e era determinante na escolha do elenco bem como do repertório. As representações aconteciam à noite, em duas sessões, sem descanso semanal. Além disso, as companhias de comédias alteravam suas peças em cartaz com uma freqüência elevada, que pressupunha além de muito trabalho e disciplina, uma organização do elenco diferenciada. Cada companhia tinha um intérprete para cada diferente tipo de papel. Assim, havia entre os homens um galã, um centro cômico, um centro dramático e as pontas; entre as mulheres, uma ingênua, uma dama-galã, uma caricata e uma dama-central.

\begin{abstract}
Assim aparelhada, com atores cobrindo todas as idades e todas as especializações interpretativas, podia a companhia enfrentar com segurança qualquer texto, tanto mais que este também fora concebido quase certamente obedecendo a esta mesma tipologia dramática. Variam as palavras, as peripécias de enredo seriam outras, mas a linha geral do desempenho já estava assegurada de antemão pela experiência que tinha o ator naquele gênero de personagem. ${ }^{66}$
\end{abstract}

Compunham também a companhia o ensaiador e o ponto. O primeiro era responsável por traçar a mecânica cênica da peça, desde a disposição dos objetos até a circulação dos personagens no palco. O segundo, além de comandar toda a representação da peça (controle das luzes, subida e descida do pano e ruídos e sons durante a cena), também supria as falhas de memória dos atores, principalmente nas primeiras representações. $\mathrm{O}$ ponto compensava, "como princípio disciplinar, a relativa desimportância do ensaiador, ao passo que a criação momentânea de palco supria o que pudesse ter havido de insuficiente no período de preparação da peça" ${ }^{67}$.

Essa estrutura pré-determinada impedia uma experimentação e um maior avanço nas concepções do espetáculo, já que a bilheteria cheia e a garantia de sucesso não impulsionavam qualquer sentimento de mudança. Sendo assim, os primeiros atores e donos

\footnotetext{
${ }^{66}$ PRADO, Décio de Almeida. O Teatro Brasileiro Moderno. 2ed. São Paulo: Perspectiva, 2003. p. 15.

${ }^{67}$ Idem, p. 19.
} 
de companhias brilharam no início do século XX e conquistaram, ao longo de suas carreiras, a admiração do público e da crítica dos periódicos pesquisados.

\section{Companhia Leopoldo Froes}

Passada a época de João Caetano e do ator Vasques, chegava Leopoldo Froes para marcar a história do teatro brasileiro no início do século XX. Nascido em 1882, Froes viveu um constante embate com as preferências familiares, contra sua dedicação ao mundo artístico. Bacharel em direito, para gosto do pai, Froes seguiu para Paris e, posteriormente, para Lisboa, onde fez parte de algumas companhias dramáticas. Organiza com Simões Coelho e Geraldo Magalhães sua primeira Companhia, que estreou com a peça Viúva Alegre. De volta ao Brasil, começa a construir uma carreira de êxito; em 1915, estréia no "Pathé-Cine" ao lado de Lucília Peres e, em 1917, vai para o Trianon, onde irá performar os grandes sucessos de sua vida.

Entretanto, uma série de desentendimentos com Lucília Peres acaba por dissolver a companhia, o que permitiu que ele seguisse sozinho em sua empreitada rumo ao topo:

As brigas com Lucília revelam o tino empresarial de Leopoldo Froes. Consciente que a esmagadora maioria das pessoas ia ao teatro interessada não exclusivamente na peça, mas principalmente no ator que a encena, e desejando obter sempre o maior lucro possível, foi aos poucos se apoderando da companhia para que esta pudesse operar apenas no intuito de valorizar a sua estrela, o mais possível. Não queria espetáculos que não fizesse brilhar qualquer outro artista que não ele, pois não pretendia dividir os lucros e as glórias com pessoas que não corriam os "riscos" do negócio. Tudo deveria girar em torno de Froes, pois exatamente para isso existia a companhia. Quem não estivesse satisfeito que abandonasse o elenco e tentasse criar uma companhia própria ${ }^{68}$.

Seus anos de Trianon geraram lucro, sucesso e conflitos; o ego de Froes batia de frente com o da "celebridade Trianon", que deveria triunfar por si só, independente do artista e/ou empresário que estivesse ocupando seus palcos. Para o diretor do teatro - J. R. Staffa - nunca o sucesso e a glória de um único artista poderiam ser mais grandiosos que o

\footnotetext{
${ }^{68}$ FERREIRA, Adriano de Assis. Teatro Trianon: forças da ordem X forças da desordem. Dissertação de
} Mestrado. São Paulo: FFLCH/USP, 2004. p. 92. 
marketing do próprio Trianon. Entretanto, o processo que se estabeleceu nas décadas iniciais do século XX ia no caminho inverso:

O ator-empresário converteu-se numa espécie de vedete, numa mercadoria, que passou a valorizar-se independentemente dos teatros e das companhias. A 'elite popular' passou a freqüentar o teatro não apenas pela qualidade do 'bom' teatro em prosa, mas principalmente pelo fascínio exercido pela presença em cena da grande estrela. Em algumas ocasiões, sua presença lotava as salas mesmo se os textos fossem maus, ou mesmo sabendo a platéia que eles seriam desrespeitados ${ }^{69}$.

As páginas de Fon Fon dedicam grande parte de suas colunas aos feitos do ator. Encontramos ao longo da pesquisa notas sobre algumas das peças de seu repertório, como: Zazá, de Mário Pedro e Seixas Pereira em agosto de 1922 (13.2.1.2); O Simpático Jeremias, de Gastão Tojeiro em outubro de 1922 (13.2.1.5); Quebranto, de Coelho Neto em setembro de 1923 (13.3.5.4); Somos o que eles Querem, de Ruy Castro em dezembro de 1923 (20.1.3); Gigolô, de Renato Vianna em setembro de 1924 (13.3.4.6) e $O$ Violão e o Jazz-Band, de Duvernois e Dieudonné em maio de 1925 (13.2.1.17).

A grande parte da crítica teatral da época, considera Froes como um astro, juntamente com Dulcina e Procópio Ferreira. Destoando desse coro, estava Antônio de Alcântara Machado, que, como já dissemos anteriormente, culpava os grandes empresários em nada fazer para alterar o quadro de franca "miséria" em que nosso teatro se encontrava.

Em contraste à opinião de Alcântara Machado, anteriormente citada de seu artigo publicado na Revista Nova, os colaboradores de Fon Fon consideravam Leopoldo Froes como vítima de seu público e da época em que viveu. Destacamos de um texto sem indicação de autoria o seguinte argumento apresentado em razão da morte do ator (13.2.1.22):

O teatro brasileiro acaba de perder, com a morte de Leopoldo Froes, em Davos-Platz, o seu mais alto valor histórico, a sua máxima expressão no momento. O eminente artista aliava a uma cultura invulgar e a uma educação primorosa a mais espontânea das vocações, que se traduzia no dom de naturalidade, no realismo artístico, marcando

\footnotetext{
${ }^{69}$ Idem, p. 105.
} 
fortemente a sua individualidade de ator. Foram essas altas qualidades que o tornaram o ídolo das platéias brasileiras e portuguesas, e que o obrigaram, pela exigência tirânica do público, a sacrificar por vezes mais altos ideais artísticos. Leopoldo Froes fez muito pelo teatro do seu país, mas muito mais teria feito, se o meio e, principalmente, o tempo em que viveu o não acorrentassem às futilidades de uma arte ligeira, em que se debatia a sua alma de grande ator. Sacrificou-se realmente às exigências do público, mas, mesmo através dessa transigência, havia um clarão de beleza em tudo quanto aquele espírito vibrante punha a nota inconfundível da sua arte alegre e sadia. Leopoldo Froes faz falta ao teatro brasileiro pelo muito que ainda havia a esperar do seu talento, mas, sobretudo, porque, olhando-se em volta, não se encontra um nome que possa, com justiça, ocupar o lugar que ele deixou vago.

A atitude tomada por Froes vai ao encontro das adotadas pelos artistas-empresários da época, que concentravam em si toda a engrenagem do espetáculo. A ausência da figura de um diretor permitia que as regras fossem estabelecidas por aqueles que atraíssem o público aos teatros e garantissem o faturamento das bilheterias. Anti-teatral ou não, essa organização perdurou até bem depois de sua morte, tendo Procópio Ferreira como seu seguidor.

\section{Companhia Procópio Ferreira}

Por quase três décadas ele reinara inconteste - o ator mais engraçado de um teatro que se queria unicamente cômico. Recebera inclusive a mais alta homenagem prestada aos seus grandes homens pela opinião pública brasileira - perdera o sobrenome. Quando se falava em Procópio, ninguém tinha dúvida de que se tratava naturalmente de Procópio Ferreira. Pois eis que de repente chegávamos nós, com outras idéias, outros métodos, outra dicção cênica, outra concepção de teatro. No mesmo ano - 1948 - em que ele fazia cinqüenta, inaugurava-se, fruto de um decênio de esforço amador, o 
TBC. Procópio atingia a maturidade e já tinha de ceder lugar, não por decadência física ou histriônica, mas por força de uma dessas viradas históricas decisivas, aos que começavam apenas a subir ${ }^{70}$.

Depois de algumas décadas de intensa influência estrangeira, de companhias e atores europeus que aqui desembarcaram, o teatro nacional vivenciava uma retomada da presença nacional, seja nos palcos com Apolônia Pinto, Leopoldo Froes e Abigail Maia, seja na dramaturgia com Viriato Correa, Armando Gonzaga, Oduvaldo Vianna e Gastão Tojeiro. Segundo Décio de Almeida Prado, é nessa eclosão do teatro nacional que estréia Procópio Ferreira, destaque absoluto nas revistas de nossas pesquisas.

Nascido em 1898, Procópio iniciou muito jovem sua carreira como ator. Participou da Companhia de Lucília Peres logo após a conclusão do curso na Escola Dramática em 1916; ingressou na Companhia Itália Fausta em 1918; na praça Tiradentes com Pascoal Segretto, obteve ao lado de Abigail Maia seu primeiro grande êxito em A Juriti, de Viriato Correa; foi para o Trianon em 1920; e formou em 1924 sua própria empresa/companhia que brilharia nos palcos das grandes cidades brasileiras nas décadas de 20 e 30 .

Seus anos de glória coincidem com o período delimitado nesta pesquisa. Seus triunfos eram todos registrados na imprensa periódica da época, que valorizava, promovia e enaltecia suas criações. Sua companhia ganha destaque na maioria das revistas consultadas, seja por meio de notas, fotos e ilustrações ou críticas a respeito de seus personagens. A partir de nossos registros, esboçamos abaixo um quadro com as peças encenadas por Procópio Ferreira, com as respectivas datas que estavam em cartaz e as entradas no índice para fácil localização:

\begin{tabular}{|c|c|c|c|}
\hline DATA & PEÇA & AUTOR & ÍNDICE \\
\hline Abr/ 1923 & Casamento Americano & Vicentina Soares & 13.5 .15 \\
\hline Jul/1923 & Zuzu & Viriato Correa & 13.5 .18 \\
\hline Jan/1925 & Tio Solteiro & Ricardo Hicken & 13.3 .4 .8 \\
\hline
\end{tabular}

\footnotetext{
${ }^{70}$ PRADO, Décio de Almeida de. "Procópio Ferreira: Um Pouco da Prática e um Pouco da Teoria". In: Peças, Pessoas, Personagens: O Teatro Brasileiro de Procópio Ferreira a Cacilda Becker. São Paulo: Companhia das Letras, 1993, pp. $41-91$.
} 


\begin{tabular}{|c|c|c|c|}
\hline Fev/1925 & O Baile de Máscaras & $\begin{array}{c}\text { Mario Poppe e Domingos } \\
\text { Cardoso }\end{array}$ & 13.3.5.6 \\
\hline Jun/1925 & Cala a Boca Etelvina & Armando Gonzaga & 13.3 .5 .8 \\
\hline Jan/1926 & Aluga-se uma Mulher & Paulo de Magalhães & 13.5 .28 \\
\hline Mar/1926 & O Homem das Cinco Horas & Hennequim e Veber & 21.2 .1 .27 \\
\hline Mai/1926 & Velhice Desamparada & Paulo de Magalhães & 13.2 .1 .18 \\
\hline Ago/1926 & Bicho Papão & Viriato Correa & 13.2 .1 .27 \\
\hline Out/1926 & O Sobrinho do Homem & Benjamim de Garey & 19.2.1.29 \\
\hline Out/1926 & Bancô! & Octavio Rangel & 19.2.1.29 \\
\hline Out/1926 & Os Girassóis & Oduvaldo Vianna & 19.2 .1 .29 \\
\hline Abr/1928 & Que Noite, Meu Deus! & Matheus de Fontoura (trad.) & 13.5 .34 \\
\hline Jun/1928 & Guerra às Mulheres & Paulo de Magalhães & 13.5 .34 \\
\hline Jul/1928 & Os Três Gêmeos & Matheus de Fontoura (trad.) & 13.5 .34 \\
\hline Mar/1929 & Camila Arranja um Noivo & Matheus de Fontoura (trad.) & 13.5 .38 \\
\hline Mar/1929 & O Chefe Político & Matheus de Fontoura (trad.) & 13.5 .38 \\
\hline Abr/1929 & O Querido das Mulheres & Paulo de Magalhães & 13.5 .39 \\
\hline Ago/1932 & Feitiço & Oduvaldo Vianna & 13.5 .44 \\
\hline Jul/1934 & Deus lhe Pague & Joracy Camargo & 23.3.2.1 \\
\hline Fev/1938 & As Três Helenas & Humberto Cunha & 24.2 .1 .34 \\
\hline Mai/1938 & Um Homem e Oito Mulheres & Elmeric Folder & 24.2 .1 .41 \\
\hline Mar/1939 & Carneiro de Batalhão & Viriato Correa & 24.3 .5 .4 \\
\hline Mar/1940 & Maria Cachucha & Joracy Camargo & 24.2 .1 .58 \\
\hline Jun/1940 & Suicídio por Amor & Abadie Faria Rosa & 24.3 .2 .50 \\
\hline Out/1941 & O Marido da Estrela & Paulo de Magalhães & 18.2.1.1 \\
\hline Nov/1941 & Papai Felisberto & Carlos Goldoni & 18.2 .1 .4 \\
\hline Nov/1941 & O Pão Duro & Amaral Gurgel & 27.3 .2 .7 \\
\hline Abr/1942 & O Inimigo das Mulheres & Carlos Goldoni & 28.3 .2 .2 \\
\hline
\end{tabular}


Podemos perceber que em seu repertório figuravam peças de autores estrangeiros como o argentino Benjamim de Garay e traduções de comédias alemãs realizadas por Matheus de Fontoura, bem como peças de autores nacionais submetidos todos ao mesmo processo de encenação, no qual a peça era centrada no primeiro ator.

Em 1955, foram registrados os seguintes nomes em seu repertório: 21 peças de Joracy Camargo, 17 peças de Paulo de Magalhães, 8 peças de Viriato Correa e Armando Gonzaga, 7 de Eurico Silva, 5 de Oduvaldo Vianna, 4 de Raimundo Magalhães Junior, Dias Gomes, José Wanderley e 3 de Pedro Bloch. Seus maiores sucessos de bilheteria foram Deus lhe Pague, O Maluco da Avenida, Cala a Boca, Etelvina! e Feitiço ${ }^{71}$.

$\mathrm{O}$ momento era do teatro do ator - assim, como não havia ainda a figura de um encenador, o autor devia seguir o processo de construção já estabelecido para que suas peças tivessem vez nas mãos dos empresários. Procópio, detentor de renome e sucesso, seguia sempre a mesma fórmula de modo a manter-se no estrelato. Sua zona de conforto era justificada pela preferência do público, que, segundo o ator, era pela comédia de costumes que fizesse rir e descontrair. Para ele, a composição de sua platéia era determinante na escolha e montagem de suas peças:

Sou, antes de tudo, um ator do Povo. Nunca tive pretensão de me colocar acima dele. Há muitos anos que o vejo diante de mim, risonho, feliz e satisfeito. Isso me basta. Eu e ele nos compreendemos. Falamos uma mesma linguagem, sentimos as mesmas dores, sofremos os mesmos desenganos. Ele vem ao meu teatro em busca de ilusões. Essas benéficas ilusões nascidas de um humorismo sadio, que o faz rir durante algumas horas dos defeitos de uma sociedade sem rumo ${ }^{72}$.

Por diversas vezes nos deparamos com críticas calorosas em relação ao trabalho de Procópio. Entre elas está a de Domingos Cardoso que, em janeiro de 1925, proferiu as seguintes palavras nas páginas de Fon Fon (13.3.4.8):

\footnotetext{
${ }^{71}$ PRADO, Décio de Almeida. Op. cit. p. 78.

72 FERREIRA, Procópio. Procópio Apresenta Procópio: Um Depoimento para a História do Teatro no Brasil. Rio de Janeiro, Rocco, 2000, p. 293.
} 
O triunfo de Procópio Ferreira foi definitivo, pois o jovem ator patrício é uma legítima glória do teatro nacional. As duas criações que acaba de apresentar quer no - Tio solteiro como em Minha prima está louca - são dois trabalho de relevo e dignos da qualificação de formidáveis. Procópio já não é mais uma revelação promissora do teatro nacional. O grande ator patrício tem de ser, desde já, orgulho do teatro brasileiro. Com elementos como Procópio poderia firmar-se definitivamente o conceito de nosso teatro; isto é, o que até agora tem sido sonhos e tentativas vãs, poderia realizar-se, tendo em vista o grande exemplo desse novo. Data de ontem o aparecimento em cena do modesto artista que, pouco a pouco, pelo seu valor intrínseco, pelo seu esforço, pela sua vontade, venceu e venceu em triunfo, ruidosamente, com a consagração simpática do povo e da crítica, que lhe render homenagens ao seu talento de artista meticuloso.

Além de valorizar seu trabalho como ator, a crítica - como voz do povo - enaltecia e privilegiava o gênero comédia. Berilo Neves, em julho de 1929, afirma que (13.3.4.10):

O palco é a miniatura do mundo. Assim como a gota do mar contém todos os elementos físico-químicos que compõem o oceano, também as cenas do teatro resumem a comédia universal da Vida. E a vida, que nem sempre é trágica nem dramática, é diariamente e irremediavelmente, cômica. A tragédia, como a fizeram Shakespeare e Ésquilo, é uma exceção do sentimento. O drama é um enredo demasiado complexo para ser quotidiano. Só a farsa é diuturna, porque só a farsa é a alma mesma da Vida. Procópio Ferreira é um cômico-padrão. O que vale dizer: é um grande artista, cuja compleição específica de inteligência e de alma o tornou apto a reproduzir, de maneira assombrosa, a imensa comicidade humana. Ele sabe, como ninguém, evocar certos estados de alma onde se reflete de maneira mais aguda a fragilidade da nossa compleição moral. Vendo-o no palco, dando vida e animação às personagens (nem sempre animadas e vivas...) dos autores que interpreta, tem-se a impressão exata de já ter visto, na vida, a cena que está em cena... Sente-se que já se sentiu aquele estado de alma.

Procópio seguia assim os passos de Leopoldo Froes, centrando em si a organização da companhia e do espetáculo como um todo. Ambos eram apoiados por entusiastas e 
aplaudidos pelo público. Antônio de Alcântara Machado cede para Mário Nunes o árduo papel de criticar a mesmice dos grandes empresários teatrais. Em sua coluna intitulada "Teatro" da revista Frou Frou, Nunes aponta a ambição de Procópio em só querer o sucesso de sua bilheteria, o que o impedia de inovar e experimentar novas tendências em sua companhia. O crítico aponta o desinteresse do público em assistir peças inovadoras como as de Álvaro Moreyra (21.3.3.4).

Com essa crítica de junho de 1929, podemos afirmar que Procópio não reinava em absoluto. Havia aqueles que, buscando ares de renovação, clamavam pelo não tradicional e acusavam os 'sucessos de bilheteria'. Entretanto, a própria crítica de Mário Nunes revela um paradoxo na tríade do teatro nacional. Álvaro Moreyra, entusiasta das tentativas de renovação, não conseguia atrair para suas peças um público considerável que garantisse a permanência de suas peças em cartaz. Por outro lado, Procópio, ao insistir no gênero comédia, garantia público, sobrevivência e triunfo nos palcos.

Questiona-se hoje o porquê da inação dos grandes empresários e da não tentativa de se buscar o novo, o diferente. Entretanto, estabeleceu-se naquele momento uma tríade que funcionava e que se bastava. O próprio desenrolar dos anos foi mostrando que esse tripé não se sustentaria por muito tempo. Novos elementos passariam a ser levados em conta e o novo dinamismo que se estabeleceu no teatro nacional foi, pouco a pouco, afastando Procópio dos grandes centros. Perdeu a atualidade, mas nunca a personalidade e a confiança em si mesmo. Representou enquanto seu corpo permitiu, até falecer em 1979.

\section{Companhia Jaime Costa}

Nascido em 1897, Jaime Costa só foi se interessar pela arte teatral em 1920, ao ser convidado a participar do Grupo de Amadores Sales Ribeiro. Depois, participou do Clube Ginástico Português, uniu-se a Leopoldo Froes e Almeida Cruz para organizar uma companhia de Operetas para o Recreio, participou de uma peça da Companhia de Comédia de Froes, até ser convidado por Odulvado Vianna a ingressar na Companhia de Comédias do Trianon, organizada juntamente com Viriato Correa. Estreou na comédia Última Ilusão, do próprio Oduvaldo, e nunca mais abandonou o gênero. 
Em 1924, com a dissolução da companhia, une-se a Belmira de Almeida e Átila de Morais. Nessa companhia, embarca para diversas excursões pelo sul e centro-oeste até retornar para o Trianon em 1929.

Nas páginas das revistas literárias e culturais pesquisadas, Jaime Costa e sua companhia são destaque constante principalmente em Fon Fon, Boletim da S.B.A.T. e Dom Casmurro. Por meio de notas e críticas, pudemos fazer um levantamento dos originais que levou aos palcos. Eis, em ordem cronológica, as realizações da Companhia Jaime Costa, entre 1922 e 1942, com as respectivas datas que estavam em cartaz e as entradas no índice:

\begin{tabular}{|c|c|c|c|}
\hline DATA & PEÇA & AUTOR & ÍNDICE \\
\hline Dez/1922 & Bezerro de Ouro & Heitor Modesto & 13.5 .11 \\
\hline Jul/1923 & Zuzu & Viriato Correa & 13.5 .18 \\
\hline Out/1923 & Fogo de Vista & Coelho Neto & 13.5 .23 \\
\hline Out/1923 & Graças a Deus & Armando Gonzaga & 13.2 .1 .14 \\
\hline Ago/1925 & D. João André & Abadie Faria Rosa & 19.2 .1 .10 \\
\hline Ago/1925 & O Homem do Cinema & Simões Coelho & 19.2 .1 .10 \\
\hline Jun/1926 & Meu Amor & Abadie Faria Rosa & 19.2 .1 .24 \\
\hline Jun/1927 & Arte de Seduzir & Cláudio de Souza & 14.5 .14 \\
\hline Nov/1927 & Sorte Grande & Bastos Tigre & 19.2 .1 .43 \\
\hline Nov/1927 & Prudêncio Temerário & Manoel Mattos & 19.2 .1 .43 \\
\hline Ago/1931 & A Estrada dos Deuses & Abadie Faria Rosa & 13.2 .1 .20 \\
\hline Mar/1933 & O Outro André & Correa Varella & 13.5 .14 \\
\hline Mai/1933 & Dindinha & Matheus Fontoura & 13.3 .5 .11 \\
\hline Jun/1933 & A Patroa & Armando Gonzaga & 13.3 .5 .13 \\
\hline Jun/1933 & Loucura Sentimental & Benjamin Constallat & 13.3 .5 .14 \\
\hline Jun/1933 & O Outro Amor & Leopoldo Froes & 13.3 .5 .15 \\
\hline Jun/1933 & História de Carlitos & Henrique Pongetti & 13.3 .5 .12 \\
\hline Mai/1937 & Uma Loira Oxigenada & Henrique Pongetti & 24.3 .2 .2 \\
\hline Fev/1938 & Homem que Nasceu 2 Vezes & Oduvaldo Vianna & 24.2 .1 .33 \\
\hline
\end{tabular}




\begin{tabular}{|l|c|c|c|}
\hline Fev/1938 & O Baile de Máscaras & $\begin{array}{c}\text { Henrique Pongetti e Luis } \\
\text { Martins }\end{array}$ & 24.2 .1 .33 \\
\hline Fev/1938 & Fora da Vida & Joracy Camargo & 24.2 .1 .33 \\
\hline Ago/1939 & Carlota Joaquina & Raimundo Magalhães Jr. & 26.2 .1 .1 \\
\hline Jan/1942 & Ladrão do Meu Coração & Ligia Sarmento & 18.3 .4 .9 \\
\hline Jan/1942 & Berenice & Roberto Gomes & 18.3 .4 .10 \\
\hline Mar/1942 & A Família Lero-Lero & Raimundo Magalhães Jr. & 18.2 .1 .7 \\
\hline
\end{tabular}

Podemos perceber que o gênero mais representado por Jaime Costa é o mesmo que estava em voga nas décadas de 20 e 30: a comédia. Em seus elencos figuraram quase todos os artistas nacionais, como Dulcina de Morais, Iracema de Alencar, Belmira de Almeida, Eugênia Brazão, Ligia Sarmento, Heloísa Helena, entre outras ${ }^{73}$. Entretanto, antes de definir seu teatro como mais um componente do sistema que produzia um teatro que fizesse rir, rir, rir, precisamos lembrar que ele também apresentou ao teatro nacional obras de Eugene O’Neil, Pirandello e Arthur Miller, com o estrondoso sucesso de A Morte do Caixeiro Viajante.

\section{Companhia Dulcina-Odilon}

Dulcina de Morais Azevedo, filha dos artistas Conchita e Átila de Moraes, nasce em 1908, imersa no meio teatral. Sempre acompanhando seu pai no Trianon, assistia a diversos ensaios da Companhia Leopoldo Froes.

Um dia a Companhia Leopoldo Froes vai para o Teatro Carlos Gomes, da Empresa Pascoal Segreto. O nosso grande ator via-se em sérias dificuldades então para arranjar uma primeira atriz. Sua atenção foi despertada para aquela mocinha em quem notara sempre uma grande habilidade e maior talento. Conversou com Átila que não se opôs, sabendo que esse era o desejo dela. Logo de início, nos ensaios, Froes entusiasmou-se. E, naquele ano, que ficará marcado na história do nosso Teatro, 1924, na peça Lua Cheia, Dulcina de

\footnotetext{
${ }^{73}$ ABREU, Brício de. Op. cit. p. 194.
} 
Morais colhia os seus primeiros triunfos de estreante e o teatro nacional ganhava uma extraordinária atriz. A crítica foi unânime ${ }^{74}$.

Nesse mesmo ano, Froes decide fazer uma excursão pela Argentina e Uruguai. Dulcina foi junto nessa que foi a primeira vez em que uma companhia brasileira se apresentava em palcos estrangeiros. Mais uma vez a crítica enalteceu as qualidades da atriz.

Quando a carreira de Froes começa a declinar, Dulcina já estava lançada e estabelecida como uma grande atriz. Participou de uma série de elencos de comédias, como o de Jaime Costa, Mesquitinha, no Trianon e no Teatro São José.

Ela casa-se com o companheiro de elenco Odilon Azevedo em 1931. Manuel Durães e Átila organizam uma companhia que percorreu o norte e sul do Brasil. Em setembro de 1933, a Companhia Dulcina-Durães-Odilon estréia a peça Amor, de Oduvaldo Vianna, no Teatro Boa Vista em São Paulo. Em 1934, essa mesma companhia inaugura o Teatro Rival no Rio de Janeiro com a representação da mesma peça, que atingiu êxitos sem precedentes. Seria a primeira vez que uma mulher lideraria uma companhia em uma época predominada por atores masculinos.

Sérgio Viotti, em seu livro dedicado à atriz, divide a carreira de Dulcina em algumas etapas, das quais consideraremos duas: 1. 1933-1937: Anos Consolidadores; 2. 1937-1943: Anos Consagradores ${ }^{75}$. Essas duas fases podem ser percebidas por meio da natureza das notas e artigos publicados sobre a Companhia Dulcina-Odilon.

Nos anos da primeira fase, registramos principalmente notas indicando as estréias da companhia: em abril de 1934, o Boletim da S.B.A.T. registra a estréia da companhia com a peça Amor, de Odulvaldo Vianna na inauguração do Teatro Rival (19.2.1.66); em julho de 1934, a Revista Brasileira publica uma foto do casal com a legenda "expoentes do teatro de comédia nacional" (23.5.1); em março de 1935, a mesma revista notifica a estréia de Esta noite ou nunca, de Lili Hatvany e Bebezinho de Paris, dos argentinos Darthés e Damel no Teatro Rival (23.5.1); em agosto de 1935, o periódico Fon Fon destaca o grande empreendimento de Dulcina, Odilon e Oduvaldo Vianna na representação da peça Le Bonheur, de Bernstein, com tradução de Heitor Muniz (13.2.1.26); em maio de 1937, o

\footnotetext{
${ }^{74}$ ABREU, Brico de. Op. cit. p. 161.

${ }^{75}$ VIOTTI, Sérgio. Dulcina e o Teatro de seu Tempo. Rio de Janeiro: Lacerda, 2000.
} 
hebdomadário Dom Casmurro publica uma nota sobre a viagem dos "embaixadores da cultura brasileira" a Los Angeles em visita aos cineastas e artistas de Hollywood (24.2.1.2); em setembro do mesmo ano, Brício de Abreu, crítico teatral de Dom Casmurro, escreve uma crítica positiva à peça Tovaritch, de Jacques Deval, nos palcos do Rival; ele destaca as qualidades artísticas de Conchita e Átila de Moares (24.3.2.19); e para encerrar essa fase, o mesmo periódico publica em dezembro de 1937 a realização do Festival Dulcina no Rival com a peça Quando Foge a Mocidade, de Samson Raphaelson.

Já a partir de 1938, registramos em nossa pesquisa não apenas notas de estréias, mas também críticas mais detalhadas das peças encenadas, as iniciativas e polêmicas em torno da Companhia Dulcina-Odilon.

Os anos consagradores seriam de muito mais sucesso, divulgação e atenção para a companhia: em abril de 1938, o Boletim de Ariel aponta o enorme sucesso da peça Marquesa de Santos, de Viriato Correa, em cartaz no Teatro Sant'Anna em São Paulo pela Companhia Dulcina-Odilon (22.3.2.1); em maio do mesmo ano, Dom Casmurro notifica a estréia de Fontes Luminosas, de Verneuil (24.2.1.41), e em junho a estréia de Mentirosa, de Raimundo Magalhães Júnior (24.3.5.2), marcando a volta da troupe aos palcos do Rival; representando a época de ocupação do Teatro Alhambra, da Empresa Serrador, o mesmo periódico anuncia a estréia de $O$ Secretário da Madame, de Jacques Deval em abril de 1939 (24.2.1.55); depois dessa temporada, a companhia estreou no Teatro Serrador com a peça Sinhá Moça Chorou..., de Ernani Fornari (24.2.1.60); a montagem de Comédia do Coração, de Paulo Gonçalves no Teatro Regina ganha destaca na coluna se Sylvia Moncorvo nas páginas de A Cena Muda de dezembro de 1941 (18.2.1.6) e na critica de Décio de Almeida Prado na revista Clima de abril de 1942, quando a montagem é feita em São Paulo (28.3.2.2).

Além das notificações de estréias e críticas de performances, houve uma polêmica envolvendo a Companhia Dulcina-Odilon que ocupou algumas páginas das revistas por nós consultadas. Em junho de 1941, Dom Casmurro patrocina um concurso organizado por Dulcina, Odilon e Procópio Ferreira, que tinha por principal objetivo incentivar a nova dramaturgia nacional. As peças concorrentes deveriam ser escritas em 3 atos e ser originais. A peça vencedora, além de reverter prêmios em dinheiro, seria representada pelas Companhias Dulcina-Odilon e Procópio Ferreira (24.2.1.61). Após essa publicação, a 
iniciativa gerou reconhecimento e aplauso de outras publicações, como foi o caso da revista Cultura Política que, por intermédio de Raimundo Magalhães Júnior, destacou a bela iniciativa das companhias em representar autores nacionais (27.3.2.6).

Entretanto, em janeiro de 1942, Dom Casmurro publica que nenhuma peça inscrita no concurso era merecedora do prêmio e digna da representação das Companhias patrocinadoras (24.2.1.63). Essa decisão gerou insatisfação no meio teatral, que considerou arrogante e injusto o resultado. Guilherme Figueiredo, em seu artigo À Margem de um Concurso, publicado em fevereiro em 1942 nas páginas da Revista do Brasil (16.3.2.5), critica o resultado final do concurso. Segundo o autor, as dificuldades de um novo autor nacional ganhar destaque em nossa cena são várias: primeiro, devido ao número restrito de companhias de comédias e casas de espetáculo; segundo, porque as companhias existentes preferem originais de autores conhecidos do público e da crítica, que garantem o sucesso das bilheterias; e terceiro, por conta da falta de repertório, as companhias preferem traduzir obras estrangeiras, principalmente as que não estejam sujeitas a direitos autorais. As contribuições desse concurso seriam inúmeras já que

... ele representaria uma oportunidade de fazer originais e nomes chegarem ao conhecimento dos melhores elencos de comédia que possuímos. Mesmo que o prêmio fosse apenas um estímulo, proporcionaria uma possível renovação de quadros entre os escritores teatrais. Certamente não revelaria obras-primas, pois o gênero teatral é daqueles que só consentem trabalhos de primeiro quilate, depois de um tirocínio de técnica de diálogo, arquitetura da ação e conhecimento do palco. Por isso mesmo, o hebdomadário em questão, juntamente com as companhias que receberiam as peças, estavam na obrigação moral de escolher dois originais, por mais fracos que fossem, uma vez que se empenharam, perante o público e perante os concorrentes, nos anúncios que fizeram do certame, a favorecer novos autores teatrais, oferecendo-lhes uma oportunidade. Nunca uma iniciativa deveria ser tão louvada quanto essa.

Guilherme de Figueiredo aproveita ainda para deixar registrada uma crítica ao estilo de representação e de organização das companhias da época: 
Procópio e Dulcina exigem que as peças tenham papéis centrais com a 'feição' de Procópio e Dulcina. Não querem saber de metamorfoses dentro do palco; o que desejam é peças em que eles próprios possam servir de personagens, peças em que 'fiquem à vontade'. Daí ter-nos acontecido assistir a representações de Molière, nas quais Tartufo e Hapagão fazem o papel de Procópio; daí termos visto comédias em que Dulcina, inegavelmente a nossa melhor comediante, faz questão de representar o papel de Dulcina. Ora, dentro dessa bitola, quase que se está a impor que os escritores teatrais conheçam pessoalmente e intimamente os atores, os hábitos, os temperamentos, as maneiras de ser de cada um dos componentes do elenco. Haverá, santo Deus, alguma coisa de mais antiteatral? Uma grande atriz, um grande ator, incidentalmente 'pedem' um papel ao comediógrafo. Este, porém, é mais importante do que a figura que vai para a cena.

Ao lermos tudo o que foi publicado sobre a Companhia Dulcina-Odilon nas páginas por nós pesquisadas, podemos afirmar que a pupila de Leopoldo Froes ganhou fama e renome nos palcos nacionais na primeira metade do século XX. Dulcina, assim como Procópio e Froes, fazia parte de um sistema teatral que girava em torno do primeiro ator, dono e principal estrela da companhia. Sérgio Viotti, em ocasião de sua morte, registra na revista Manchete palavras de despedida em agosto de 1995:

Ela teve o aplauso dos críticos, a veneração do público; o respeito dos alunos, o amor dos amigos. A glória, para ela, não eram tapetes vermelhos nem manchetes elogiosas. Era a certeza de ter transmitido sua experiência aos alunos, e sua maior esperança era ter-lhes ensinado o amor respeitoso pelo Teatro e pela profissão. Por tudo isso, pelas alegrias que nos deu e pelo que lutou pelo nosso Teatro e não esquecemos, a nossa gratidão sempre e sempre ${ }^{76}$.

Passada a Revolução de 30, o advento do cinema e a demasiada exploração do gênero comédia, as grandes cidades começam a adquirir uma nova dinâmica. Às vésperas do início da Segunda Guerra, visitas estrangeiras voltam a ser constantes, bem como a circulação de idéias novas nos diversos meios artísticos. Com o advento da década de 40, uma nova era se inicia, a do encenador, consolidada apenas na década de 50.

\footnotetext{
${ }^{76}$ Idem. p. 606.
} 
A mentalidade crítica e artística começa a atingir a maturidade necessária para exigir mais de uma produção extremamente inalterada e, conseqüentemente, esgotada. Grupos de estudantes e amadores, bem como novas companhias são formadas diferentemente daquelas centradas no primeiro ator e outros gêneros passam a ser explorados.

A presença de um encenador, responsável pela autoria do espetáculo, e da percepção do espetáculo como resultado de uma arte produzida coletivamente foi aos poucos distanciando os grandes nomes das companhias analisadas acima dos palcos nacionais. Procópio Ferreira, por exemplo, não se conformava com a nova concepção de teatro que estava sendo pleiteada pelos novos. De qualquer modo, o teatro moderno viria equacionar o problema dos empresários-estrelas, adotando a figura do diretor - "sua presença controlaria a vaidade das estrelas, lembrando que estas não estavam em companhias próprias, mas alheias, e tingiria a atividade empresarial de uma aparência de preocupação abstrata não monetária, mas artística, que justificaria a submissão dos atores"77.

Essa relativa demora da modernização do teatro brasileiro em relação às outras artes resultou em uma sensação de "vazio", de "lacuna" nas duas décadas posteriores à Semana de Arte Moderna:

Ao tomar contato com o palco, a nova geração, vendo os espetáculos sob o signo de uma dramaturgia desse gênero, quando os seus mestres literários haviam sido os modernistas, tinha forçosamente de considerar o teatro uma arte caduca, em atraso indesculpável com a poesia e o romance. Daí se terem arrolado como passadistas todos os dramaturgos que floresceram nessas décadas - um Viriato Correa, um Oduvaldo Vianna, um Ernani Fornari, um Abadie Faria Rosa, e o incrível Paulo de Magalhães, que se jactava de ser o autor mais representado do Brasil. Alguns tinham uma certa competência profissional, na acepção de carpintaria eficiente, mas que nunca se iluminou com um verdadeiro halo poético ${ }^{78}$.

Moderno, com certeza não foi. Vazio e sem expressão também não. Os anos que antecederam o início do moderno teatro brasileiro foram repletos de representações e discussões entre os fazedores e pensadores da arte teatral. Suas características são

\footnotetext{
${ }^{77}$ FERREIRA, Adriano de Assis. Op. cit. p. 107.

${ }^{78}$ MAGALDI, Sábato. Op. cit. p. 203.
} 
claras e marcantes e constituem um importante período da história do teatro nacional que não deve ser ignorado. 


\title{
3. Do Futuro e da Morte do Teatro Brasileiro
}

\begin{abstract}
O século XX não está sozinho ao perguntar se o teatro está em crise. Já Sêneca, em Roma, e Lessing, em Hamburgo, questionaram o sentido e a forma do teatro de sua época. [...] A frase de Hamlet sobre o teatro como "a crônica abstrata e abreviada do tempo" talvez nunca tenha sido mais verdadeira do que hoje. A breve crônica da era atômica que apenas começou está saturada de problemas, de controvérsia social, sociológica, psicológica e política, de ilusória autoconfiança de uma parte e mal-estar e protesto, de outra, da suave radiação dos homens de boa vontade e da turbulenta vigília dos que dirigem o mundo para uma nova catástrofe. $\mathrm{O}$ teatro permanece exatamente no meio de tudo isso ${ }^{79}$.
\end{abstract}

A história do teatro ao redor do mundo nos revela a constante e incessante crença na extinção da arte teatral, ultrapassada e eliminada pela evolução de outras artes. Discutir a crise, seja de um gênero específico, seja do teatro como um todo, sempre fez parte da rotina dos fazedores de teatro e com certeza figura entre os principais temas abordados pelos intelectuais e críticos teatrais ao longo do tempo.

Certamente nas primeiras décadas do século XX não havia de ser diferente. O mundo, em rápida transformação, apresentava o que havia de mais moderno em todas as esferas do cotidiano. A perspectiva transforma-se dia-a-dia numa onda de novidades.

No mundo artístico, a evolução do cinema e seu aperfeiçoamento nas grandes cidades brasileiras deram um novo rumo às produções e às discussões sobre o assunto. $\mathrm{O}$ encantamento com a grande tela gerou páginas e páginas de discussões entre uma maioria que constatava a morte do teatro, considerada como a arte das gerações passadas, e uma minoria que defendia sua sobrevivência e evolução eterna. $\mathrm{O}$ advento do cinema, como arte representativa do século XX, colocou os intelectuais das décadas de 20 e 30 em um embate

\footnotetext{
${ }^{79}$ BERTHOLD, Margot. História Mundial do Teatro. 2ed. São Paulo: Perspectiva, 2004. p. 522.
} 
fervoroso, sustentado muito mais por opiniões pessoais e impressões do que tendências e argumentos mais concretos sobre o assunto.

Ao longo da década de 20 percebemos que mais um personagem começa a ganhar espaço no mundo do entretenimento: o rádio. Meio de comunicação que visa chegar às massas, o rádio atinge um novo público e estabelece também uma certa concorrência entre os fazedores de arte. Agora, inicia-se uma disputa por um público maior. O teatro não é mais a única opção; assim, atrair outras classes sociais torna-se vital para garantir os mesmos rendimentos de antigamente.

Nas páginas das revistas consultadas, predominam as discussões sobre a ameaça do cinema e sobre a expansão do rádio-teatro como novo gênero. Pretendemos discorrer aqui sobre as transformações que tanto o cinema quanto o rádio provocaram no mundo artístico da época e os argumentos sustentados pelos intelectuais que tanto temiam a morte da arte teatral.

\section{1 - Choradeira sem Propósito}

$\mathrm{O}$ início do século $\mathrm{XX}$ apresenta mudanças significativas nos aspectos organizacionais, políticos, sociais e artísticos das grandes cidades. O início da industrialização, a implementação do comércio, o aparecimento de novos artefatos tecnológicos e a operacionalização de novos meios de transporte e de comunicação promovem o surgimento de um mercado consumidor em potencial e estabelecem uma nova dinâmica na organização social das metrópoles:

A cidade moderna torna-se o cenário, por excelência, dos conflitos mais relevantes da modernidade, especialmente aqueles associados à convivência de tempos de extrema racionalidade, característicos da modernidade, - trabalho, calendário, agenda social com outro tempo, o da resistência das interioridades subjetivas. $\mathrm{O}$ processo modernizador trouxe consigo a racionalização de condutas, a proposta de homogeneização de costumes e de consumo. A contrapartida da multiplicação das escalas do ambiente urbano foi o encolhimento da figura humana e a projeção da 
multidão como um personagem em si mesmo, anunciando o surgimento da sociedade de massa ${ }^{80}$.

O cinema, por sua dinâmica própria, proporcionava o fenômeno de ajuntamento coletivo e de socialização, passando a ser um dos principais pontos de encontro nas primeiras décadas do século XX. Com efeito, seu crescimento nas grandes cidades foi proporcional ao encantamento que promovia no público. Registrou-se em São Paulo um elevado aumento das casas de cinema na década de 20; eram vinte e dois cinemas em oposição a oito teatros em 1930.

A formação e, depois, a consolidação do mercado cinematográfico ia além da construção de salas de exibição; havia todo um aparato que constituía o negócio do cinema, como a criação e circulação de periódicos especializados (O Eco, A Cena Muda, Cinearte etc), o aumento de críticas cinematográficas que passaram a disputar e ganhar espaços nas colunas de arte, o investimento em equipamento para projeção e filmagem nacional e, um pouco mais tarde, a definição de uma política protecionista para o setor, envolvendo produtores, realizadores e técnicos do cinema brasileiro.

Pudemos observar nos periódicos consultados que as seções, inicialmente reservadas aos acontecimentos da vida teatral, passaram a ser seções sobre teatro e cinema e posteriormente, substituídas inteiramente pelo cinema. Na revista Fon-Fon, por exemplo, encontramos a seção Teatros nos números que circularam na década de 20; com a aproximação dos anos 30, esta seção passou a se chamar Notas de Arte, que incluía informações sobre artes plásticas, cinema, teatro e música. Já a revista Cultura Política apresentou a seção Teatro até o número 19, depois se tornou Cinema e Teatro e posteriormente, Cinema.

A partir dos anos 30, tanto a sociedade quanto a cultura brasileira desatam os laços com a influência francesa e voltam-se para os Estados Unidos. A hegemonia econômica e cultural americana, que dominou todo o século XX, atraía diversos tipos de interesse dos países em desenvolvimento. O novo universo do consumo atinge a todos e os símbolos divulgados por Hollywood e Disneylândia são referências que se difundem mundialmente.

${ }^{80}$ FERRARESI, Carla Miucci. Papéis Normativos e Práticas Sociais: o Cinema e a Modernidade no Processo de Elaboração das Sociabilidades Paulistanas na São Paulo dos Anos de 1920. Tese de Doutorado. São Paulo: FFLCH/USP, 2007. 
A mídia, como instrumento de circulação de idéias, teve um papel essencial na divulgação desse american way of life. O cinema, considerado como a primeira linguagem potencialmente universal, tornou-se um dos principais pólos de irradiação cultural nessa época $^{81}$ e, conseqüentemente, as revistas cinematográficas funcionavam como elo de ligação entre o cinema e o público, que descobria uma nova forma de ver o mundo.

Conforme apresentado anteriormente no capítulo 1, o mito da estrela do cinema e da adoração de seus personagens era construído e implantado às custas de muita publicidade que envolvia o negócio do cinema, incluindo as publicações cinematográficas. $\mathrm{O}$ trabalho do Departamento Nacional de Estatística, intitulado Estatística da Imprensa Periódica no Brasil (1929-1930), nem ao menos inclui o item revistas teatrais em seu quadro de publicações periódicas. Já o item revistas cinematográficas aparece listado, sendo que em 1912 não foi registrada nenhuma ocorrência e em 1930, foram apontados 10 títulos sobre a matéria $^{82}$.

Toda essa indústria do cinema, amparada em muita matéria publicitária, carregava em si a possibilidade de lucros vultuosos, atingindo um público bem maior do que o teatro.

O Cinematógrafo inventou o espectador, ou pelo menos um novo tipo de espectador, o que se vê transformado no assunto principal da imagem, o que se vê confrontado com uma imagem que questiona o seu modo de olhar. Esse novo espectador inventado pelo cinema, ali, no instante da invenção, reagiu como se estivesse vendo o mundo pela primeira vez, abrindo seus olhos pela primeira $\mathrm{vez}^{83}$.

As questões empresariais que moviam esse negócio e a formação de uma nova platéia assídua e interessada alteraram os planos da arte teatral, que passou a se empenhar muito mais para atrair e manter o público em seus espetáculos.

Símbolo do novo e do moderno, o cinema figurou nas páginas das revistas modernistas como o astro do século. Já mencionamos anteriormente a fascinação do grupo dos periódicos modernistas pelos encantamentos da tela. Para eles, o teatro nacional estava

\footnotetext{
${ }^{81}$ MIRA, Maria Celeste. Op. cit, p. 27.

${ }^{82}$ Estatística da Imprensa Periódica no Brasil (1929-1930). Rio de Janeiro: Departamento Nacional de Estatística, 1931.

${ }^{83}$ AVELLAR, José Carlos. "Cinema e Espectador”. In: XAVIER, Ismail. O Cinema no Século. Rio de Janeiro: Imago, 1996. p. 219.
} 
atrasado e preso às amarras do século anterior; já o cinema trazia em sua composição a significação do moderno e por isso sua presença foi tão marcante nos periódicos em questão.

Essa concorrência gerou também uma calorosa discussão que movia as esferas intelectuais brasileiras. Muito mais que um concorrente, o cinema passou a ser encarado por muitos como uma ameaça real e imediata que viria pôr fim à miséria do teatro nacional. Em 1930, João do Norte, um dos críticos de arte da revista Fon Fon, discorre sobre a decadência do teatro em um artigo intitulado $O$ Teatro Moribundo (13.3.3.1):

Em verdade, toda a doença do teatro vem, de perto ou de longe, da concorrência cinematográfica. Isso, porque este é o progresso e aquele a rotina. Com o acréscimo da luz elétrica unicamente, o teatro de hoje é o mesmo dos bons tempos do romantismo. E enquanto o teatro não arranjar meios de ficar de acordo com a nossa época, eminentemente técnica, não sairá do marasmo em que vai vegetando.

As novas técnicas apresentadas pelo cinema criam uma nova referência na análise da produção teatral; os aparatos técnicos revelam ao público uma realidade vista com um novo prisma e exigem do antigo formato dos espetáculos teatrais renovações para impedir a evasão do público. Entre os intelectuais, estabeleceu-se uma necessidade de defesa que vinha à tona por meio de soluções infalíveis que impediriam a morte do teatro. "O teatro, para se defender, precisa não cair mais no erro da nossa civilização moderna, erro que consiste em pedir muito às palavras e nunca se dirigir aos sentidos. Defender-se de forma diversa da tentada até hoje (24.3.3.4)".

Havia também aqueles que argumentavam de maneira mais racional, ponderando as condições de produção do cinema frente às do teatro de modo a analisar a concorrência entre as duas artes. O periódico Fon Fon lançou uma enquete intitulada "Nosso Teatro em Foco", na qual perguntava, entre outros assuntos, se o cinema era a verdadeira causa da crise teatral. Entre as repostas, separamos a do autor e diretor do S.N.T. Abadie Faria Rosa (13.4.1). Vejamos sua consideração sobre a pergunta acima:

Em parte. O cinema disputa com vantagens a preferência do público. A película, mesmo quando o assunto não é bom ou não foi explorado com felicidade, é 
tecnicamente completa e materialmente perfeita. E não é só. O cinema conta, pela multiplicidade ambiente de que dispõe, com detalhes que melhor exteriorizam a ação e melhor particularizam os meandros do entrecho. No cinema, por isso, não se exige a atenção necessária à compreensão do assunto como no teatro. E o público dos nossos dias é muito comodista. Por outro lado, como as cópias de um filme são infinitas, é possível arriscar na sua confecção capitais que o negócio do palco não permite pelo número restrito de exibições que uma peça pode proporcionar em face das reproduções transmitidas pelo 'écran'. Há mais ainda. Uma obra de teatro que exija cenografia grandiosa, elemento cômico numeroso, grande orquestra e muitos outros recursos de palco não poderá ser levada aos pequenos centros de população, ao passo que o mais luxuoso superfilme pode praticamente ser exibido em qualquer cinema. Um exemplo claro, qualquer película passada na tela da Cinelândia pode ser focalizada num cinema dos subúrbios. Nem todas as companhias de teatro poderão atuar nos palcos de Madureira ou Meyer. Em geral, os espetáculos teatrais, que podem ser oferecidos ao público dos centros pequenos, estão muito longe dos filmes que são passados nas telas desses lugares. Como se vê, é uma concorrência difícil de ser contornada, tanto mais que há ainda a ponderar o preço da localidade, sempre menor nos cinemas.

Podemos observar em suas palavras uma análise mais sedimentada sobre a concorrência do cinema. Seus argumentos vão além da simples questão do encantamento pelo novo, pelo moderno. Faria Rosa aponta as vantagens da sétima arte: o uso de técnicas que exteriorizam a ação e proporcionam a multiplicidade de ambiente no decorrer da historia; o número irrestrito de exibição que garante um maior retorno e, por conseguinte, uma maior possibilidade de investimento de recursos durante as filmagens; e o preço das localidades que acabam barateando o custo. Todos esses pontos devem ser levados em conta quando da análise da concorrência entre as artes e da preferência do público. O cinema, além de ser atrativo pela novidade, apresentou ao público uma forma de entretenimento mais acessível do que o teatro, atingindo também outras classes sociais.

É interessante ressaltar as diferentes visões apresentadas sobre a caracterização da platéia da época. Acima, Faria Rosa aponta que o público daqueles dias era muito comodista e que buscava uma fonte de diversão que exigisse um menor esforço de compreensão. Por outro lado, havia aqueles que acreditavam que as inovações trazidas pelo 
cinema refinaram o gosto do público que passou a ser mais exigente com as produções teatrais que assistia. Armand Salacrou afirma que:

Acho que a arte cinematográfica influiu na arte teatral num sentido: modificar o gosto do público, pois os espectadores de teatro vão todos, ou quase todos - e muitas vezes mais - ao cinema. Os filmes lhes deram o gosto do ritmo mais rápido, do elemento documentário, tornando-os mais exigentes quanto à interpretação (24.3.3.4).

Já Antônio de Alcântara Machado, em seu artigo "Um Aspecto da Renovação Contemporânea" (14.3.3.1), defende de modo mais contundente as vantagens que a arte teatral obteve com o advento do cinema:

Seja como for; o que é inegável é que o teatro só teve e tem a lucrar com o advento do cinema e o prestígio sempre maior do café-concerto. Sob a influência forçada de um e de outro, vem adquirindo novas maneiras de expressão, estendendo seu campo de ação, aumentando sua potência plástica, atualizando-se. Sim, porque se para a platéia antiga bastava a exclusividade teatral (teatral emprega-se aqui no sentido técnico e o objetivo da realização) a de hoje já não se satisfaz só com isso. Quer mais. E faz bem de o querer. Ora, ao contrário do romancista, por exemplo, o dramaturgo luta contra uma consciência coletiva, síntese de mil consciências individuais e tem de vencê-la de um só golpe. Não separadamente como aquele. Substitua-se consciência por tendência estética ou gosto artístico e o conceito nada perde de sua justeza.

A alteração do gosto do público também é vista como algo positivo para Georges Delamare, diretor artístico da televisão do estado na França, em seu artigo intitulado "A Televisão é a Morte ou a Ressurreição do Teatro?" (24. 3.3.5). Escrito em 1940, o autor apresenta uma visão posterior às discussões citadas acima, tendo agora o advento da televisão como um outro fator de preocupação:

De 30 anos pra cá, depois da época grandiosa de 1900, tão rica de inteligência e tão caluniada, a arte teatral ganhou em qualidade, mas perdeu em quantidade. O público, esclarecido pelo cinema, afastou-se dos espetáculos medíocres. Mas, em compensação, correu para os espetáculos perfeitos. Daí o desaparecimento inevitável das cenas 
pobres. Daí o triunfo do cenário sublime, da elevação teatral, poderosamente sustentada e sublimada pela iluminação e maquinaria a serviço da "mise-en-scene".

Retomemos brevemente a um dos principais defensores da continuidade da arte teatral: Antônio de Alcântara Machado. $\mathrm{O}$ autor protagoniza uma série de discussões sobre o assunto, sempre apontando para os benefícios que o teatro teria com as inovações propostas pelo cinema e pela renovação vitoriosa que aquele poderia ter. Com Martins de Almeida discutiu calorosamente sobre o assunto nas páginas da Revista do Brasil. Para Almeida, o teatro não é capaz de representar as complexidades e profundidades do homem moderno devido à insuficiência da ação dramática, da composição do diálogo e à falta de identidade artística. Ele aponta ainda que o gênero teatral não se preocupa com a individualidade do espectador, já que "limita extremamente a livre expansão da força criadora, o pleno desenvolvimento da personalidade" (16.3.3.3).

$\mathrm{Na}$ mesma revista citada acima, encontramos uma série de artigos de Alcântara Machado em defesa da sobrevivência e da evolução da arte teatral. Sempre com uma ironia implícita, ele rebatia todos os argumentos infundados de seus colegas de profissão. Podemos perceber o modo com o qual ele abordava o assunto apenas observando os títulos de seus artigos: "Choradeira sem Propósito" (16.3.3.2), "Da Estupidez dos Oráculos" (16.3.3.4), "Pelo Réu" (16.3.3.5) e "Do Futuro e da Morte do Teatro (Mais uma Vez)" (16.3.3.6). O autor aponta que a adaptação de princípios cinemáticos à arte teatral levaria à variação e universalização do caráter distintivo do teatro como arte:

Meios de evocação, simultaneidade, movimento, plasticidade, perfeição rítmica, liberdade de fantasia - tudo isso o teatro dentro de suas possibilidades vem procurando imitar do cinematógrafo. Para lucro seu. Com o café-concerto aprende o traço rápido, a síntese fulminante, a força no burlesco, a instantaneidade cômica, o vigor caricatural. O imprevisto, o multiforme poder impressivo (14.3.3.1).

É certo que o advento do cinema provocou no cenário artístico da época uma significativa mudança. $\mathrm{O}$ teatro precisou se re-inventar para acompanhar as transformações no mundo do entretenimento. A popularização das casas de espetáculo, o número elevado de exibições, as novas técnicas utilizadas na grande tela, o sabor da novidade e o 
encantamento com os grandes astros geraram um novo mercado, especializado em divulgar, expandir e estabelecer o mito dos astros de Hollywood.

Ao longo da década de 30, novos fatores passaram a ser considerados como justificativa da crise teatral. Agora, a capacidade dos autores também é colocada em cheque. Augusto Frederico Schmidt, em seu interessante artigo "Mauriac, Lorca e a Eternidade do Teatro" (16.3.1.8), aponta que a década de 30 estava condenada por uma ausência de autores capazes de elevar o teatro contemporâneo e conduzi-lo de maneira vigorosa e original. Sobre a influência do cinema, ele afirma que:

O cinema, por exemplo, não tem nada com o teatro. É outra coisa, é outra arte. Tem o seu caminho diferente. Para os que olham o problema de maneira mais profunda, para os que olham o teatro na sua realidade, e não apenas através das aparências, - a arte teatral não terá com o cinema, rigorosamente senão uma relação, - e assim mesmo incerta - de origem, relação que não significará, absolutamente, uma identidade de destino, que não deixará jamais supor a substituição de uma coisa pela outra. Creio mesmo que o cinema, quanto mais se afasta do teatro, mais se torna obra de arte. A sua libertação dos processos teatrais, a libertação do teatro, do espírito teatral - aproxima o cinema da sua força, da sua plenitude, da sua integração como realidade artística. Dizer-se, pois, que no triunfo avassalador, indiscutível, completo do cinema - está a explicação da decadência do teatro é afirmação apressada e superficial.

Para ele, o cinema, arte nascida da técnica, seguirá outro caminho e jamais substituirá o teatro, arte baseada no melhor do gênio humano. Essa questão sobre a técnica ainda é retomada diversas vezes em outros momentos e outros contextos. E. Roquette-Pinto destaca que a evolução da arte cinematográfica não resultou de novos moldes da arte cênica; não proveio dos atores, nem dos literatos, mas sim, da química e da física dos aparelhos utilizados:

Não é demais concluir que foi o progresso técnico a força decisiva da evolução da própria arte cinematográfica. O progresso não resultou de novos moldes da arte cênica. Não proveio dos atores... nem dos literatos. Veio da física dos aparelhos e da química 
dos filmes. Na aparelhagem o principal, talvez, tenha sido a parte relativa aos sons. É bem difícil gravar um bom disco; muito mais, gravar um bom sono-filme ${ }^{84}$.

O autor destaca ainda uma série de outras inovações que promoveram em conjunto a evolução e expansão da arte cinematográfica, que estabelecia uma nova referência e despertava no espectador uma nova maneira de ver, sentir e inferir sobre a realidade. Para ele, a nitidez, que traduz todas as nuances das cores e que possibilita o registro de cenas filmadas quase no escuro; as cores naturais, elementos preciosos que dão ao filme valor documentário e estético; a velocidade da filmagem, que gera efeitos de câmera lenta e câmera veloz; as fusões, que permitem o desaparecimento gradual de uma cena enquanto surge a próxima, revelam o desenvolvimento da arte cinematográfica não apenas enquanto entretenimento, mas também como fonte educativa moderna. A valorização do cinema começa a extrapolar os limites de sua indústria, invadindo agora centros educacionais e de formação.

A primeira metade do século XX presenciou o embate entre duas forças artísticas que buscavam sua consolidação junto ao mercado. Qualquer passo à frente dado por um impulsionava o passo do outro. Mesmo com a impressão de estar sendo ameaçado, o teatro absorveu e adaptou as influências do cinema e seguiu seu caminho rumo à sua própria evolução. As discussões entre os intelectuais também contribuíram para as mudanças, já que eram fontes de opinião das platéias e referência para os fazedores de arte. Com o advento da segunda metade do século XX, o sentimento de ameaça e o perigo de extinção se dissiparam. Percebeu-se que o cinema e o teatro poderiam co-existir e conviver, cada um a seu modo. O teatro mostrou-se capaz de se re-inventar e de conquistar em definitivo seu espaço na indústria do entretenimento.

\footnotetext{
${ }^{84}$ ROQUETTE-PINTO, E. “A Evolução do Cinema”. Revista do Brasil. Rio de Janeiro: Julho/1938, pp. 74 80.
} 


\subsection{Teatro pelos Ares}

Até o século XIX, os serviços de telecomunicações estavam ligados às atividades do comércio, à navegação e à defesa do território nacional. As primeiras décadas do século XX registram a urbanização das cidades, o progresso industrial e a implementação de decretos que possibilitaram os avanços da radiodifusão no nosso país.

Com o decreto $n^{\circ} 3.296$, de 10 de julho de 1917, a regulação das telecomunicações passa a ser de exclusividade do Governo Federal, que se torna o controlador dos serviços de radiotelegrafia e radiotelefonia no lugar das políticas das províncias regionais ${ }^{85}$. Com essa unificação, a primeira demonstração de radiotelefonia aconteceu na Exposição Internacional do Centenário da Independência em 1922 no Rio de Janeiro.

A saudação sonora do presidente Epitácio Pessoa foi irradiada através da estação de 500 watts montada no alto do Corcovado pela companhia norte-americana Westinghouse, captada por alto-falantes instalados em pontos estratégicos da exposição e pelos aparelhos de rádio distribuídos pelo governo em São Paulo, Petrópolis e Niterói. ${ }^{86}$

$\mathrm{Na}$ intenção de levar o pensamento por toda a extensão do território nacional, Edgard Roquette Pinto - hoje considerado o "Pai da Radiodifusão Brasileira" - e Henrique Morize - presidente da Academia Brasileira de Ciências e diretor do Observatório Nacional fundam a Rádio Sociedade do Rio de Janeiro. Com finalidades educativo-culturais, dá início às suas transmissões em 20 de abril de 1923.

Foi somente quatro meses depois que o então presidente Arthur Bernardes autorizou oficialmente o início das irradiações no Brasil. Considerada pelos governantes como uma arma perigosa, as transmissões só seriam autorizadas se abordassem conteúdos educativos. Sob as mesmas bases, foi constituída em São Paulo, em 30 de novembro do mesmo ano, a Rádio Educadora Paulista.

\footnotetext{
${ }^{85}$ JAMBEIRO, Othon et all. Tempos de Vargas: O Rádio e o Controle da Informação. Salvador: EDUFBA, 2004. p. 47.

${ }^{86}$ SAROLDI, Luiz Carlos e MOREIRA, Sonia Virgínia. Rádio Nacional: o Brasil em Sintonia. 3 ed. Rio de Janeiro: Jorge Zahar Editor, 2005. p. 15.
} 
A década de 20 foi marcada pelo surgimento de diversas rádios nos grandes centros do país. No Rio de Janeiro, após a fundação da Rádio Sociedade do Rio de Janeiro, foram fundadas as seguintes emissoras: a Rádio Club do Brasil, em 1924; a Rádio Educadora do Brasil, 1926; e a Rádio Philips, em 1930. Em São Paulo, tivemos depois da Rádio Educadora Paulista, a Rádio Club de São Paulo, em 1924; a Rádio Cruzeiro do Sul, em 1927; e a Rádio Sociedade Record, em 1928, fundada por Álvaro Liberato de Macedo, proprietário da casa de discos Record. As primeiras rádios do Nordeste foram a Rádio Club Pernambuco e a Rádio Sociedade da Bahia ${ }^{87}$.

Nessa década, a radiodifusão era organizada em torno de associações sem fins lucrativos, por intelectuais que contribuíam mensalmente com a manutenção de suas sociedades e clubes. Mesmo sem ter um objetivo econômico ou político que movesse essas organizações, elas iam surgindo em todo o país, atingindo o número de 19 no início de 1930.

A partir daí a situação muda radicalmente. O rádio passa a ser um aliado dependente do sistema industrial e comercial da economia, tornando-se uma importante ligação entre a produção e o consumo. A radiodifusão:

começa a ser organizada com sentido claramente econômico e veículo para o estímulo ao consumo de produtos industrializados, em grande escala, o que muda o conteúdo e o alcance de sua regulamentação. A partir de então, juntam-se aos aspectos técnicos, os fatores de segurança nacional, do controle sócio-político do país e da influência na opinião pública ${ }^{88}$.

Apesar de a imprensa estar consolidada na década de 30, os índices de analfabetismo superavam $60 \%$ da população do país, o que desencorajava grandes investimentos no setor. Assim, a indústria de comunicação de massa restringia-se ao cinema e à indústria fonográfica. O rádio começou a ser considerado como importante instrumento de comunicação com as massas quando lhe foi atribuído valor político ao transmitir os

\footnotetext{
${ }^{87}$ JAMBEIRO, Othon et all. Op. cit. p. 43.

${ }^{88}$ Idem, p. 44
} 
acontecimentos das Revoluções de 30 e 32 e quando o mercado consumidor brasileiro se tornou atrativo para as agências de propaganda americanas.

Com a industrialização do centro-sul brasileiro, o mercado para bens de consumo expandiu-se gradualmente para outras partes do país. Com isso, as emissoras de rádio começaram a ter patrocinadores e tornaram-se bem sucedidas comercialmente. A programação que antes enfatizava notícias e alta-cultura, dirigida àquelas camadas com posses suficientes para adquirir um aparelho de rádio, foi sendo mudada com a introdução de programas de entretenimento, destinados a atender às novas camadas de consumidores, situadas nas classes média e baixa ${ }^{89}$.

Com a regulamentação da publicidade paga nas transmissões radiofônicas, conforme decreto $\mathrm{n}^{\mathrm{o}}$ 21.111, assinado em 1932, o rádio passa a ser um importante veículo de propaganda, perdendo suas características de erudito, instrutivo e cultural. Agora, além de propiciar às emissoras uma sustentação econômica necessária, o novo decreto permitiu que o rádio se transformasse em um meio popular de lazer e diversão.

Foi então que as agências estrangeiras revelaram seu interesse pela radiodifusão nacional - elas tiveram um papel determinante na elaboração e sedimentação de uma economia para o rádio. Essas agências ajudavam a produzi programas voltados para as novas massas consumidoras e, em seguida, negociavam a venda das audiências a seus anunciantes, moldando a programação brasileira ao sistema comercial americano.

Esse modelo importado e implantado no Brasil se caracterizava por um estilo dinâmico e eclético de programação, dirigido para audiências as mais amplas possíveis, tudo com base em anúncios de produto de largo consumo. A nova proposta exigiu investimento das emissoras, que tiveram de montar orquestras e conjuntos musicais, além de contratar atores, cantores, speakers, humoristas, programadores e produtores criativos. Ao tempo em que se estruturaram tecnicamente para atender às novas demandas, as principais emissoras brasileiras criaram também departamentos comerciais, com poder decisório sobre a programação. Por seu intermédio é que elas se relacionavam com as agências de publicidade ${ }^{90}$.

\footnotetext{
${ }^{89}$ Idem, p. 16.

${ }^{90}$ Idem p. 18.
} 
Apesar de garantir o sustento e a manutenção da programação das emissoras de rádios, os anunciantes acabaram por alterar a forma de apresentar não apenas os produtos, mas também as músicas, os artistas e os programas. Percebe-se pela manifestação dos ouvintes que o speaker acabava sendo responsabilizado pelos prejuízos na qualidade da programação. Os críticos radiofônicos interferiam por muitas vezes e rebatiam as acusações recebidas pelos locutores (13.3.2.13):

Peço licença para defender o speaker de rádio, principalmente o que não goza de nenhuma autonomia... O fato é muito simples. Esteio que é da nossa esforçada radiodifusão, que funciona a título precário, o anunciante é, praticamente, o orientador da maioria dos programas. Ele quer a irradiação de 'músicas assim', com 'piadinhas assim', e, sobretudo, com 'anúncios assim', 'pronunciados com entusiasmo para chamar a atenção'... E vai explicando como quer, mandando e exigindo, porque ele mesmo redigiu o seu caro anúncio, porque ele custou a achar aquela frase e aquele ruído 'tão interessantes', e, finalmente, porque é ele quem PAGA... E sofra o speaker, se quiser irradiar, e sofra o ouvinte, se quiser ouvir... Tal é, mais ou menos, a história dos anúncios. Naturalmente, a maior parte do público rádio-ouvinte pensa que é o speaker o autor de tanta calamidade em matéria de mau gosto, como também supõe que é ele quem escolhe os discos, quem faz os ruídos, quem late, quem mia, quem cura... Mas não é nada disso: o speaker é, tão somente, o bode expiatório do rádio...

Seja como for, esse era o preço para poder ter no ar a programação completa das emissoras; as regras dos anunciantes tinham que ser seguidas.

Inicialmente, a programação das rádios era essencialmente musical, baseada na coleção particular e no repertório musical agrupado pelos associados do clube da rádio. Nessa mesma época, a aproximação do rádio com o teatro aconteceu através de transmissões de concertos e óperas diretamente do Teatro Municipal de São Paulo e de outras salas de espetáculos, da leitura de páginas de obras literárias e declamações. O rádio, ainda ligado à elite, via no teatro uma possibilidade de preenchimento de sua programação, o que gerou a vinda de profissionais do palco para os estúdios das emissoras. 
Em julho de 1928, os atores portugueses Érico Braga e Lucília Simões interpretam no estúdio da Sociedade Rádio Educadora Paulista a peça $O$ Enigma, de Alberto de Souza Coutinho. Um pouco depois, a Companhia Brasileira de Sainete, dirigira por Odulvado Vianna, também se apresenta no mesmo estúdio ${ }^{91}$. Em março de 1929, o ator Raul Roulien, acompanhado de vários integrantes de sua companhia, apresentou-se na mesma rádio e ganhou espaço na imprensa jornalística, com uma nota no $O$ Estado de S. Paulo, de 14 de março de 1929:

Amanhã, às 21 horas e meia, o ator Roulien e vários elementos de sua companhia irão à sede da Rádio Educadora, de onde será irradiada uma peça completa de seu repertório. Será essa a primeira vez que se realizará em São Paulo uma sessão de teatro pelo rádio ${ }^{92}$.

Como os registros da época não são precisos, não temos como apontar com exatidão os primeiros nomes e as primeiras representações do radioteatro brasileiro. Os jornais e revistas ainda não noticiavam sistematicamente as transmissões, ignorando por muitas vezes experiências anteriores.

As emissoras de rádio, preocupadas em preencher a programação com transmissões ao vivo de espetáculo, enfrentam agora um novo problema. A má qualidade do som devido à precariedade dos equipamentos e a não visualização da ação dos personagens começaram a decepcionar os ouvintes. Tornava-se necessária a adequação do texto teatral à especificidade do rádio e imprescindível a invenção de recursos sonoros capazes de criar, na mente dos ouvintes, aquilo que era visível no palco ${ }^{93}$.

Assim, na década de 30, com a contratação de importantes nomes do teatro, novas propostas surgiram para o radioteatro. A Companhia Sonoarte de Revistas e Comédias Musicadas, de Carlos Valverde, propõe a inovação do gênero através da revista nos bastidores da Rádio Record em abril de 1933. Oduvaldo Vianna começa a escrever peças para o rádio, a Companhia de Radioteatro Manuel Durães apresenta peças adaptadas para o

\footnotetext{
${ }^{91}$ GUINSBURG, J., FARIA, J. R. e LIMA, M. A. de. Dicionário do Teatro Brasileiro: Temas, Formas e Conceitos. São Paulo: Perspectiva, Sesc São Paulo, 2006. p. 262.

92 APUD: SILVA, Flávio Luis Porto e. Rádio em Revista: Os Caminhos do Teatro de Revista no Rádio das Décadas de 20 e 30. Dissertação de Mestrado. São Paulo: USP, 2005. p. 56.

${ }^{93}$ GUINSBURG, J., FARIA, J. R. e LIMA, M. A. de. Op Cit. p. 262.
} 
rádio, Procópio Ferreira apresenta seu grande sucesso Deus lhe Pague, enfim, uma nova linguagem nasce para atender às necessidades da dramaturgia radiofônica. Os textos passam a ser escritos e adaptados especialmente para a transmissão via rádio e não mais complementados com explicações para a compreensão dos ouvintes ${ }^{94}$.

Essa popularização das transmissões dos programas de rádio na década de 30 chama a atenção da imprensa periódica, que passa a acompanhar as mudanças e os bastidores da vida radiofônica nos grandes centros. Além disso, sociedades e proprietários de jornais passam a investir em suas rádios próprias como o matutino Jornal do Brasil, do conde Ernesto Pereira Carneiro, concessionário da PRF-4, Rádio Jornal do Brasil e do grupo jornalístico Diários Associados, de Assis Chateaubriand, que inaugura a Rádio Tupi em 1935.

Nos periódicos pesquisados neste trabalho, destacam-se Fon Fon e Dom Casmurro como portadores dos principais acontecimentos do mundo radiofônico, principalmente os relacionados com o radioteatro. É por meio das páginas de Fon Fon que conseguimos coletar grande parte dos dados sobre a vida radiofônica da década de 30 e sobre os avanços do radioteatro. Em setembro de 1935, a revista inicia uma seção intitulada PR-1 Fon Fon com notícias, opiniões, entrevistas, fotos e concursos sobre a produção radiofônica dos grandes centros.

Em um artigo publicado nessa seção em 1938 - Impressões da Imprensa Radiofônica (13.2.1.28) - percebemos que esse tipo de crítica não era exclusividade de Fon Fon. Muitos outros periódicos tinham críticos que se dedicavam a esse novo ramo de entretenimento. Entre eles, destacamos os seguintes: João da Antena, de A Nota; Juracy Araújo, de A Gazeta de Notícias; Dyonísio Fernandes, do Diário da Manhã, Julio de Oliveira, de A Tarde e Hamilton Burns Ponte, de Cinearte.

Como nossa pesquisa não incluiu os periódicos citados acima, um dos críticos radiofônicos que mais se destacou em nossa pesquisa foi Alziro Zarur, responsável pela seção de Fon Fon. Considerado como um dos mais promissores nomes do rádio, Zarur atuava como 'announcer' do Programa Casé, da Rádio Mayrink Veiga e da PRE-3, além de colaborar em várias publicações cariocas. A partir de 1940, Gomes Filho assume a posição

\footnotetext{
${ }^{94}$ Idem, p. 263.
} 
de crítico radiofônico do periódico e passa a ser um dos mais importantes colaboradores sobre o assunto.

No início, os críticos radiofônicos de Fon Fon dedicavam seus artigos às programações musicais e aos cantores da época. Encontramos, em 1937, um artigo do crítico De Muros (13.3.2.12) sobre a intenção das emissoras de rádio em organizar programas de rádio-teatro:

As nossas emissoras, ao que parece, pretendem, finalmente, organizar programas de rádio-teatro. O teatro pelo rádio já é uma bela realidade em todos os grandes centros radiofônicos do mundo, valendo por números destacados em programas admiravelmente confeccionados.

A Argentina, na América do Sul, conta com irradiações magníficas de interessantes peças em quase todas as suas inúmeras emissoras. Tratam com grande carinho essa importante parte de suas irradiações, invertem somas fabulosas no custeio das mesmas, têm em seus elencos artistas soberbos, que já brilharam e assentam enormes nomes luminosos nas fachadas dos principais teatros da capital e conseguiram, com isso, uma organização perfeita, um número incalculável de ouvintes diários e... uma quantidade de anúncios que lhes rendem milhares de pesos. E o que não será o rádio-teatro na América do Norte, o maior centro rádio-telefônico do mundo?...

No Brasil, agora, depois de algumas tentativas que fracassaram lamentavelmente, promete-se rádio-teatro. 'Teatro pelos Ares' e 'Teatro de Arte' são os dois novos programas da Mayrink Veiga e Rádio Tupi. Ambos, felizmente, têm tudo para uma vida longa e vitoriosa: bons artistas, boas peças e os nomes de Paulo de Magalhães e Margarida Lopes de Almeida a encabeçá-los.

Esperamos, contudo...

Dessa forma, investimentos foram feitos e o sucesso do novo gênero foi apenas questão de tempo. Um outro artigo, publicado um ano depois por Alziro Zarur (13.2.1.28), confirma as intenções de De Muros:

Eu e os meus brilhantes colegas de crítica radiofônica vimos batalhando, há muito tempo, pela literatura no rádio. Não podemos conceber que o 'broadcasting' prescindisse da colaboração dos que sabem escrever. Porque a cultura no rádio foi 
sempre o sonho desse notável Roquette Pinto, mestre em que ainda confiam doze humildes apóstolos da boa radiofonia. [...] Crônicas, poesias, contos, jornais falados leves e rápidos, tudo com boa música, popular ou clássica. Foi-se fazendo e os ouvintes foram gostando. E agora, confirmando o que dizíamos, alcança êxito assombroso a literatura teatral pelo rádio, motivo da aceitação surpreendente de 'Teatro pelos Ares', da Mayrink. Tínhamos ou não tínhamos razão?

Das transmissões ao vivo, a programação teatral via rádio passa a ser composta por esquetes elaborados especialmente para a transmissão radiofônica. Aos poucos as rádios adotam uma linha dinâmica de programação e formam seu próprio elenco. Agora as produções teatrais eram constantes e visavam a audiência do horário nobre - período do dia valorizado que reunia toda a família ao redor do rádio. Essa diversificação de programas levou à tentativa de se produzir pequenas comédias baseadas no gênero revista:

Da dramaturgia revisteira, além das canções e da música, para um rádio que se iniciava, os números de cortina, independentes do cenário, eram os elementos mais fáceis de serem trabalhados exclusivamente através do som. O esquete, pela ação dramatúrgica e, muitas vezes, valendo-se da cenografia - o amante atrás da coluna ou escondido dentro do armário - necessitava de um cuidado maior, embora nesses primórdios do 'sem fio', o texto radiofônico ainda engatinhasse. Era o 'teatro cego', conforme relembrariam, anos depois, os profissionais da época ${ }^{95}$.

Dessa forma, o gênero rádio-teatro começou a ganhar força e espaço nas programações radiofônicas de estações de todo o Brasil, o que atraiu diversos artistas e autores que passaram a fazer teatro pelas ondas do rádio. Yedda Gonçalves aponta em uma breve nota sobre o rádio-teatro (13.3.2.13) os destaques e revelações do ano de 1938: "Tina Vitta, Mafra Filho e Sady Cabral, que brilham ao lado de Antonio Laio e Amélia de Oliveira, dois belos valores. Além disso, três elementos que nunca fizeram parte da ribalta, Alziro Zarur, José Luis (Moacyr Bueno Rocha) e Alda Verona, foram três revelações brilhantes do rádio-teatro".

${ }^{95}$ SILVA, Flavio Luiz Porto e. Op. cit. p. 65. 
Destacamos em nossa pesquisa vários programas de rádio-teatro que passaram a figurar nas críticas de arte das páginas da Fon Fon. Entre eles estão:

\begin{tabular}{|c|c|}
\hline Emissoras do Rio de Janeiro & Programas \\
\hline 1. Rádio Mayrink Veiga & $\begin{array}{l}\text { Teatro Sherlock; } \\
\text { Ribalta do Espaço; } \\
\text { Teatro pelos Ares. }\end{array}$ \\
\hline 2. Rádio Nacional & Teatro em Casa \\
\hline 3. Rádio Tupi & $\begin{array}{c}\text { Teatro de Arte; } \\
\text { Teatro Tupi. }\end{array}$ \\
\hline 4. Rádio Cruzeiro do Sul & Teatro da Cinelândia \\
\hline $\begin{array}{l}\text { 5. PRD-5- Rádio Difusora do } \\
\text { Distrito Federal }\end{array}$ & Teatro Encantado \\
\hline 6. Rádio Educadora do Brasil & $\begin{array}{c}\text { Teatrinho de Variedades; } \\
\text { Teatro de Peneira; } \\
\text { Teatro de Amadores; } \\
\text { Teatro para Todos; } \\
\text { Teatro Policial; } \\
\text { Rádio-teatro de Pedro Bloch; } \\
\text { O Mundo Sabe Sorrir. }\end{array}$ \\
\hline 7. PRI - Rádio Inconfidência & Espetáculo Rádio Teatral \\
\hline
\end{tabular}

Os programas acima eram destaques das rádios cariocas. Como não localizamos nenhum periódico de São Paulo que abordasse o assunto, decidimos complementar essa relação com os programas das emissoras paulistanas destacados por Flávio Luiz Porto e Silva, em sua tese Rádio em Revista: Os Caminhos do Teatro de Revista no Rádio das Décadas de 20 e $30^{96}$ :

${ }^{96}$ Idem. p. 111. 


\begin{tabular}{|c|c|}
\hline Emissoras de São Paulo & Programas \\
\hline 1. Rádio Cultura & Teatro em seu Receptor \\
\hline 2. Sociedade Bandeirante de \\
Rádio & $\begin{array}{c}\text { Teatro para Você; } \\
\text { Teatro de Brinquedo }\end{array}$ \\
\hline 3. Rádio Cruzeiro do Sul & Teatro Cruzeiro do Sul \\
\hline 4. Rádio Educadora Paulista & Teatro Gracioso \\
\hline 5. Rádio Cosmos & Mistérios no Ar \\
\hline 6. Rádio Tupi & Radioteatro Relâmpago \\
\hline 7. Rádio Difusora & Grande Teatro Difusora \\
\hline
\end{tabular}

Podemos afirmar que ao longo da década de 30 muito se experimentou e se realizou no rádio-teatro brasileiro. O elevado número de programas citados acima revela o alto investimento feito pelas emissoras e o grande número de tentativas e variações da programação.

Com o avanço da década de 40, o rádio-teatro afasta-se das convenções do teatro de revista, dos esquetes e das pequenas comédias de 15 minutos ou peças curtas de um ato, nas quais predominavam o humor leve, para desenvolver textos teatrais mais longos, como comédias, dramas e adaptações de obras literárias renomadas. Essa evolução na elaboração e na realização do teatro pelas ondas do rádio consolida então o gênero rádio-teatro, que passa a ter convenções, elenco, linguagem, peças e programação próprias.

De acordo com nossa pesquisa, muitos dos programas citados acima alcançaram enorme sucesso junto aos rádio-ouvintes. Entre eles figurava o Programa Casé, da Rádio Mayrink Veiga. Lançado em 11 de fevereiro de 1932 pelo produtor pernambucano Ademar Casé (1902-1993), o programa ia ao ar aos domingos e durava de três a quatro horas. Seu 
programa ficou conhecido como ponto de partida de artistas que buscavam o sucesso; nomes como Noel Rosa, Pixinguinha, Donga e João da Baiana tiveram sua estréia nos microfones da Mayrink, que ainda sedimentava nomes como Francisco Alves, Almirante, Carmem Miranda e Aurora Miranda ${ }^{97}$.

Sua contribuição ao desenvolvimento do gênero rádio-teatro foi imensa; com os programas Teatro Sherlock, Teatro pelos Ares e Ribalta do Espaço, o Programa Casé foi conquistando ouvintes e atraindo cada vez os anunciantes. O Teatro Sherlock apresentava famosos dramas policiais em adaptações radiofônicas (13.2.1.28):

Outra iniciativa empolgante está interessando aos ouvintes: o 'Teatro Sherlock', do Programa Casé, uma novidade sensacional, que difunde os mais famosos dramas policiais, em adaptações radiofônicas de Heloisa Lentz de Almeida. É o sucesso impressionante da literatura policial, fonte de imprevistos e emoções inesquecíveis, tão do agrado dos ouvintes de todas as idades...

Em janeiro de 1939, Yedda Gonçalves aponta a qualidade da programação de rádioteatro oferecido pelo Programa Case (13.3.2.14):

O 'broadcasting' está numa fase fecunda em matéria de rádio-teatro, que empolgou os fãs. Várias estações têm rádio-teatro verdadeiramente admirável. Mas, por outro lado, a maioria não apresenta grandes empreendimentos nesse sentido. O 'Programa Casé' apresenta aos fãs um rádio-teatro ótimo - Amores Imortais e Fatos Históricos, brilhantemente escritos por Sady Cabral. E 'Ribalta do Espaço' e o 'Teatro Sherlock', este uma iniciativa original da consagrada escritora Heloisa Lentz de Almeida. É um rádio-teatro bem realizado, digno de um confronto com o das melhores estações. [...] Só tenho razões para admirar o 'Programa Casé'. Mas a principal é a que se refere ao seu rádio-teatro, fator da alma nova do veterano e sempre querido programa de Ademar Casé. Que o ‘broadcasting' siga o seu exemplo, estimulando o rádio-teatro.

\footnotetext{
${ }^{97}$ PERDIGÃO, Paulo. No Ar: PRK-30! O Mais Famoso Programa de Humor da Era do Rádio. 2ed. Rio de Janeiro: Casa da Palavra, 2003. p. 32.
} 
Além do 'Teatro Sherlock', o programa 'Ribalta do Espaço' também conquistava ouvintes e figurava nas páginas das críticas sobre o assunto. Transmitido todos os domingos às 14 horas, esse programa destacava Saddy Cabral como grande e talentoso adaptador de peças para o rádio, sendo considerado um modelo no gênero. Entre seus intérpretes estavam Maíra Filho, Tina Vitta e Moacyr Bueno Rocha (13.3.2.16).

Em outras rádios, o rádio-teatro também fazia sucesso. Zenaide Martins Saraiva comenta em nota de 1939 o segundo ano do programa 'Teatro em Casa', da Rádio Nacional. Ela destaca nomes como Conchita de Moraes, Ismênia do Santos, Abigail Maia, Celso Guimarães, Armando Duval entre outros (13.2.1.29):

Conchita de Moraes, grande nome do teatro brasileiro, continua no 'cast' do 'Teatro em Casa' da Nacional, emprestando o prestígio de sua figura ao 'broadcasting' de nossa terra. No dia 27 de setembro último, fez anos a festejada atriz, ganhando uma bonita manifestação de simpatia e amizade de seus companheiros da PRE-8 e de seus inúmeros fãs (13.3.2.23).

Havia também o Teatro Tupi, transmitido pela PRG-3 todas as segundas-feiras iniciativa de Olavo Barros e Theophilo de Barros (13.3.2.14) e o Teatro da Cinelândia, pela Rádio Cruzeiro do Sul, sob a direção de Mário Meyer e comando de Luís Iglésias; entre os atores em destaca estavam Edmundo Maia, Heloisa Helena, Paulo Roberto e Lydia Mattos (13.3.2.17).

Heloisa Lentz de Almeida, além de se destacar nas adaptações para o Teatro Sherlock, conquista ainda mais os ouvintes e a crítica ao realizar o Teatro Encantado, programa voltado ao público infantil que contava com mais de cinquienta pequenos artistas em seu elenco, de 4 até 15 anos de idade, entre cantores, pianistas, declamadores, violonistas, rádio-atores e coristas orfeônicos. Esse programa era transmitido pela PRD-5 Rádio Difusora da Prefeitura do Distrito Federal e tinha assistência de maestros e artistas como J. Octaviano, Lorenzo Fernandes, Villa Lobos, Luiza P. Quadros, Carolina Cardoso de Menezes entre outros. (13.3.2.22)

Pela qualidade e variedade dos programas apresentados, a Rádio Educadora do Brasil conquista seu espaço entre as grandes rádios brasileiras. Gomes Filho - crítico radiofônico da revista Fon Fon reconhece o trabalho da Rádio em relação ao rádio-teatro e aponta a 
legitimidade da emissora na produção e transmissão do gênero que se afasta cada vez mais das convenções do teatro e do cinema. Sua programação era ampla e diversificada: 1 . Teatrinho de Variedades - programa diário de esquetes; 2. Teatro de Peneira - para os calouros do rádio-teatro aos domingos; 3. Teatro de Amadores - para os que vencem a prova do Teatro da Peneira; 4. Teatro Policial - às terças, com as Aventuras de Roberto Ricardo, de Aníbal Costa; 5 Teatro para Todos - para os novos rádio-autores às sextas; 6 . Rádio-Teatro de Pedro Bloch - programa mensal que discutia as técnicas e os recursos do rádio-teatro como recursos cômicos e trágicos, musicais, de sincronização, efeitos especiais, qualidade e defeitos do nosso rádio-teatro, além de apresentar os principais astros, adaptadores, escritores e críticos do gênero (13.3.2.23).

A imprensa periódica, acompanhando os avanços das programações das emissoras, passa a investir cada vez mais em matérias, pesquisas, concursos e entrevistas sobre o assunto. Localizamos no número 12 da Fon Fon de 1940 (13.3.2.17), um artigo sobre o início da publicação de uma nova seção intitulada “A Semana Radio-Teatral”, por Gomes Filho. O próprio crítico explica sua função e os objetivos da página radiofônica:

O diretor ou redator de uma revista é o homem que faz um mundo para ter atualidade d'aqui a... quinze dias! Jeová do futuro, sem dúvida. Porque é preciso ter, de fato, talento criador, ou senso de oportunidade, nesta época em que o mundo dá saltos de cinco em cinco minutos, para oferecer aos leitores matéria fresquinha. Nesta nova página de FON-FON, o que nos parece mais importante a ser observado é esse ponto do efeito da opinião em face do tempo. [...]

Assim compreendendo, só nos destinaremos a fazer, semanalmente, apenas um panorama do movimento rádio-teatral da cidade. E sempre com o espírito de bastante síntese, como nos reclama o espaço: e bem incisivo, como reclama o nosso feitio de nunca deixar de traçar, a respeito do que observamos, senão uma opinião franca e sincera.

Assim, toda semana, Gomes Filho apresentava um panorama das produções de rádioteatro da cidade, comentando não apenas a qualidade do texto encenado, mas também a atuação e desempenho dos atores ao longo das cenas. Depois das análises, o crítico apontava a peça campeã da semana: 
"Tarde Demais", a peça que Victor Costa apresenta pelo afinado elenco do "Teatro em Casa”, da Rádio Nacional, PRE-8, foi para nós o melhor espetáculo da referida semana. O trabalho original de Floriano Faissal é forte pelo sentido humano e realismo em todas as suas cenas. Tem verdadeiros pontos altos, como, primeiramente, os três finais de ato. A intensidade dramática ali domina o rádio-ouvinte, sem forçar conflitos inesperados, mas tudo dentro das seqüências naturais do entrecho, que como já disse, tem um sabor de vida, cem por cento. O desempenho foi magnífico por parte dos figurantes, sobressaindo-se Ismênia dos Santos, Celso Guimarães e Zezé Fonseca. [...] Como obra social, o espírito da peça é excelente, pois mostra, ao vivo, como devem ser evitadas as vinganças pessoais apressadas, quase sempre injustas e causadoras de grandes desgraças futuras (13.3.2.17).

Os concursos também ganham espaço no periódico em questão. Localizamos no número 22 de 1938, os resultados do Concurso Radiofônico de Fon-Fon, que abrangia as categorias de melhor cantor, melhor cantora, melhor 'speaker', melhor compositor, melhor humorista, melhor programa e a música predileta (popular ou clássica). Os cinco primeiros lugares da categoria de melhor programa foram: $1^{\circ}$ lugar, Teatro pelos ares com 1.567 votos; $2^{\circ}$ lugar, Programa Casé com 451 votos; $3^{\circ}$ lugar, Hora dos calouros com 334; $4^{\circ}$ lugar, Programa Piccolino com 272 votos; e $5^{\circ}$ lugar, Programa Luis Vassalo com 152 votos (13.2.1.28).

Além do concurso radiofônico, que abrangia diversas categorias, a revista propunha também um Campeonato Anual de Rádio-Teatro de Fon-Fon, no qual era escolhida, por uma comissão julgadora especializada no assunto, a emissora vencedora. Entre os critérios utilizados estavam a variedade dos programas transmitidos; encenação de originais de autores brasileiros e qualidade da atuação dos artistas de cada emissora. Em 1941, por exemplo, a vencedora foi a Rádio Educadora do Brasil, sendo oferecido à Rádio Mayrink Veiga uma menção honrosa (13.3.2.24).

Entre as diversas matérias sobre o rádio-teatro carioca, localizamos algumas indicações de que a iniciativa de produzir teatro pelo rádio estava se espalhando por outros estados do Brasil. Dom Casmurro publica em 1940 um artigo sobre os estudantes de cursos superiores de Minas Gerais que se organizaram para apresentar todas as noites de domingo 
um espetáculo rádio-teatral nos microfones da PRI-3 Rádio Inconfidência, sob a direção de J. Carlos Lisboa. Os estudantes prometem traduções de grandes autores estrangeiros como Pirandello, Ibsen, Dannunzio e Eugene O’Neill, bem como representantes do teatro nacional como Joracy Camargo e Raimundo Magalhães Jr (24.3.2.50).

Podemos perceber, através das matérias encontradas nos periódicos pesquisados principalmente na revista Fon Fon, que o gênero rádio-teatro foi evoluindo ao longo da década de 30 e alcançou na década de 40 uma posição de destaque entre os programas das emissoras de rádios e entre os rádio-ouvintes da época. $\mathrm{O}$ rádio, que antes se apoiava na música, encontra seu ponto de equilíbrio no texto literário; nota-se ao longo da década de 40 a consolidação do rádio-teatro como um gênero específico e não mais como uma forma de teatro. Agora, as representações teatrais são referidas como "radiatro", mostrando a fusão do rádio e do teatro como o estabelecimento de um novo gênero.

As críticas radiofônicas também mostram um amadurecimento nas análises das produções, levando em conta não apenas a qualidade do diálogo e a temática apresentada, mas também as convenções necessárias para a irradiação de uma peça. Edmundo Lys, ao analisar a peça $O$ Homem que Apanhava Bofetadas, de Castro Viana, transmitida pela Rádio Cruzeiro do Sul, considera o trabalho como excelente, com um tema bem radiofônico e com bom aproveitamento dos detalhes. Entretanto, o crítico aponta o lado negativo da apresentação dos personagens e das interferências do locutor ao longo da representação. Para ele, esses recursos são característicos do romance, do teatro e do conto, mas não alcança o mesmo efeito no radiatro. Segundo Edmundo Lys,:

... não é possível, no rádio, armar como arte, uma cena de assassinato e depois apresentar o morto rindo e declarando que era brincadeira. [...] O público sabe perfeitamente que, no caso do assassinato, ninguém matou, mesmo, nem morreu de fato... Mas, o assassinato que não houve é uma parte convencional de um todo artístico. Compõe um detalhe. Integra um todo convencional, a representação dramática. Sabemos que, no fim do espetáculo, os artistas vão para casa, que aquele mundo termina com a última réplica. Mas queremos aquele mundo na sua totalidade, na soma final de sua convenção. A apresentação dos personagens fora do seu mundo, como em O Homem que Apanhava Bofetadas, torna-os ridículos, irreais - fora de realidade fictícia, em que os aceitamos. A intromissão do locutor corta a sequiência dramática, 
retira sua intensidade, intercepta o desenvolvimento lógico, essencial do drama radiofônico (13.3.2.27).

Foi também na década de 40 que um outro gênero começou a ganhar destaque nas ondas do rádio: a radionovela, sendo Em Busca de Felicidade, de Gilberto Martins a primeira que foi ao ar pela Rádio Nacional.

É curioso observar que a radiodifusão brasileira teve seu momento de grande expansão no período do Estado Novo. A comunicação pelo rádio passou a ser encarada com um importante instrumento de comunicação com as massas; estabelecendo-se uma nova visão sobre a definição de cultura:

A cultura passou a ser entendida como um instrumento de organização política e disseminação ideológica. Em consequiência, o governo criou aparatos culturais na estrutura do Estado, destinados à produção e publicização da ideologia do Estado Novo na sociedade. O relacionamento do governo com os produtores culturais tornou-se multidimensional, aí incluídos a coerção e o apoio às atividades de cultura. Da mesma forma que punia e prendia intelectuais e artistas, Vargas freqüentemente os apoiava e lhes dava sinecuras, doações e prêmios ${ }^{98}$.

Assim como os jornais e as revistas, o rádio passava por um rigoroso controle de conteúdo, principalmente das notícias transmitidas. O Estado passou a investir na implantação de emissoras estatais, como a Rádio Nacional, e no estímulo ao desenvolvimento de emissoras comerciais. O controle da radiodifusão pelo governo era exercido de duas maneiras: a. através da concessão de emissoras de rádio e de licença para importação de equipamentos; e b. diretamente, através do DIP, com a censura e a distribuição da propaganda estatal.

Como o controle também era exercido na imprensa periódica, não localizamos nenhum artigo publicado nas revistas pesquisadas sobre algum tipo de censura sobre os programas de rádio e sobre as concessões dadas às emissoras. De qualquer forma, consideramos relevante deixar registrado as condições de produção das emissoras, que eram determinantes para a escolha da programação, inclusive da temática do rádio-teatro.

\footnotetext{
${ }^{98}$ JAMBEIRO, Othon et all. Op cit. p. 12
} 
Buscamos, neste capítulo, apresentar as principais evoluções no estabelecimento da arte cinematográfica e de que modo esses avanços influenciaram a arte teatral, seja na incorporação de novas técnicas, seja nas discussões provocadas pela então ameaça dessa nova arte. Percebemos que as calorosas discussões contribuíram de certa maneira para o avanço do teatro, que sempre esteve em pauta entre os intelectuais e fazedores de teatro, provocando reflexões, planejamento e consideráveis modificações. Muito longe de ser uma ameaça, o cinema tornou-se um dos propulsores que garantiram os avanços da arte teatral.

Apresentamos também o estabelecimento das produções radiofônicas de teatro, apontando os principais programas e artistas e as críticas sobre suas atuações. As transmissões das peças pelo rádio popularizaram o gênero, apesar de não ter estabelecido uma real ameaça às peças encenadas nos palcos dos tradicionais teatros do país. Com a evolução do gênero, o rádio-teatro foi conquistando formas e características tão particulares que acabou se afastando cada vez mais das irradiações das peças realizadas em teatros. O gênero atingiu seu principal propósito: de desenvolver técnicas particulares tanto de autoria das peças quanto de técnicas de representação. 


\section{4 - O Processo de Afirmação da Cena Moderna Brasileira}

No teatro brasileiro, [...] a questão da instabilidade da cena moderna e o seu conturbado processo de afirmação estão delimitados por questões mais amplas, referentes ao processo histórico, gerador e demarcador de seu impulso. [...] O seu ponto de partida foi o esgotamento da antiga máquina de repetir, um teatro que persistiu em atividade a partir do século XIX sem que ultrapassasse, em suas linhas poéticas mestras, formas popularescas de expressão e construção; havia o descontentamento diante da máquina expresso já pelos primeiros pioneiros do moderno; foi iniciado um processo técnico amador de mudança da cena, com a busca da encenação, a formação de atores, a mudança da técnica de palco. Este processo, local, nosso, que supunha mesmo algum intermédio entre a parte antiga $e$ a parte moderna, foi acelerado em função da vinda de diretores estrangeiros, resultado da guerra. Foi iniciada a fase heróica da modernidade ${ }^{99}$.

A partir das palavras de Tania Brandão, em seu estudo sobre o Teatro dos Sete, damos início às nossas considerações sobre o processo, lento e conturbado, de afirmação da cena moderna nos palcos nacionais. Considerada por muitos como lacuna, vazio e/ou atraso, a época delimitada entre a Semana de Arte Moderna e a encenação de Vestido de Noiva em 1943 apresenta em si um acúmulo de acontecimentos que proporcionaram a constituição do teatro brasileiro moderno, consolidado somente na década de 50.

Inicialmente, a fórmula do teatro ligeiro demonstra um esgotamento de suas variações, o que leva os pioneiros a novas tentativas e experimentações. Sem rupturas

\footnotetext{
99 BRANDÃO, Tania. A Máquina de Repetir e a Fábrica de Estrelas: Teatro dos Sete. Rio de Janeiro: 7Letras, 2002. p. 51.
} 
notáveis na cena teatral, chega a vez da ação dos grupos de teatro amador, que iniciam efetivamente o processo de modernização teatral, que é acelerado pela vinda de diretores estrangeiros. Essa fase heróica da modernidade, pautada nos reflexos da modernização da cena européia, é caracterizada pelo advento do encenador - ou diretor - responsável pela articulação do espetáculo como um todo. Uma decorrência imediata desse processo foi

a supressão do histrionismo-vedetismo-estrelar característico do século XIX, mudança acompanhada pelo advento da interpretação enquanto técnica sistematizada mais além do mero espontaneísmo. Um outro elemento novo foi a transformação do estatuto do próprio texto teatral, que surgiu despojado das estreitas e rígidas convenções de outrora, despontou como liberdade, ao menos em termos comparativos com as predeterminações anteriores, afirmou-se como veículo para efeitos estéticos os mais variados. A listagem das mudanças abrange desde o uso multifacetado da luz e do som até o abandono do figurino convencional ou arbitrário, passando pela liberdade de tratamento do espaço, pelo nascimento da cenografia e pela descoberta da teatralidade. O que era talento natural para a cena se transformou em conquista possível através de um método; a codificação dos papéis teatrais em uma hierarquia desapareceu, para que surgisse a liberdade completa diante das infinitas hipóteses do ser humano. O ponto, garantia da rapidez de confecção, foi suprimido, e cada montagem se tornou um novo desafio, um processo específico de preparação ${ }^{100}$.

Várias foram as iniciativas e as tentativas nos anos que antecederam a década de 50. Partindo das considerações acima, dos estudos já existentes sobre o assunto e, principalmente, do material por nós coletado, pretendemos neste capítulo estudar os passos desses pioneiros, que visualizaram e deixaram marcas de modernidade em suas realizações. Precursores ou não, entendemos que esses intelectuais - que pensavam e faziam teatro nas décadas de 20 e 30 - contribuíram de alguma forma para o processo de afirmação da cena moderna brasileira. Tentaremos contrapor as opiniões dos críticos da época e dos estudiosos renomados contemporâneos, considerando as características da classe intelectual e a forma pela qual ela se organizava, a estrutura da vida teatral da primeira metade do século XX e o papel que o Estado realizava no cenário artístico da época.

${ }^{100}$ Idem, p. 17. 
A fase heróica dos anos 20 ficou conhecida como a fase de denúncia de um país atrasado e arcaico, sob influência das amarras acadêmicas. As constantes mudanças no setor econômico, político, social e cultural geraram a formação de um novo pensamento entre a intelectualidade brasileira, que se colocou a serviço da modernização como um todo.

Uma fração 'europeizada' dessa intelectualidade brasileira, predominantemente formada pelos dirigentes paulistas, encabeçou diversos movimentos culturais, financiando artistas por meio do Mecenato. Essa classe, detentora das grandes fortunas de café, protege e estimula os escritores, artistas e intelectuais da nova fase, defendendo a arte moderna contra a estética 'passadista' da Academia:

Educada na Europa, culturalmente refinada, adaptada aos padrões e aos estilos da vida moderna, não apenas podia aceitar a nova arte como, na verdade, necessitava dela. Por outro lado - e isso ajuda a explicar o caráter 'localista' que marca tão fundamente o Modernismo - a par do seu 'cosmopolitismo' a burguesia faz praça de sua origem senhorial de proprietária de terras. $\mathrm{O}$ aristocratismo de que se reveste precisa ser justificado por uma tradição que seja característica, marcante e distintiva - um verdadeiro caráter nacional que ela represente em seu máximo refinamento. [...] Dessa forma, os artistas do Modernismo e os senhores do café uniam o culto da modernidade internacional à prática da tradição brasileira ${ }^{101}$.

Assim, delineou-se ao longo da década de 20 uma trajetória de recuperação da nacionalidade, da cor 'local' - a arte passa a ser um importante instrumento no permanente embate entre o 'novo' e o 'velho'. Seguindo a tese de Luiz Lafetá, entendemos o Modernismo como um movimento de renovação estética que se constitui em duas faces complementares: "enquanto projeto estético, diretamente ligado às modificações operadas na linguagem, e enquanto projeto ideológico, diretamente atado ao pensamento (visão de mundo) de sua época ${ }^{102,}$.

Como propõe o autor, utilizaremos essa distinção de forma dialética, já que qualquer mudança no campo estético reflete em si mesma uma mudança no campo ideológico; da

\footnotetext{
${ }^{101}$ LAFETÁ, João Luiz. 1930: A Cultura e o Modernismo. São Paulo: Duas Cidades, Ed 34, 2000. p. 24.

${ }^{102}$ Idem, p. 20.
} 
mesma forma que uma ideologia pode se disfarçar em formas múltiplas de linguagem sem alterar o teor de suas concepções. Então, longe de atribuir um caráter mecânico a esse instrumento de análise, utilizaremos essa distinção de modo a buscar a complementaridade desses dois aspectos e os pontos de tensão existentes entre eles.

A experimentação estética caracteriza a primeira fase do Modernismo, a partir de radicais mudanças na concepção da obra de arte como um todo. Renovam-se os meios, rompe-se a linguagem artificial para implementar diversas inovações na construção e representação da linguagem. Entretanto, colocar em prática esse anarquismo da concepção formal gerou ruídos em diversas esferas da sociedade. Cassiano Ricardo em seu livro Viagem no Tempo e no Espaço afirma que:

Nada mais difícil, entretanto, do que quebrar padrões formais já solidificados. Difícil avaliar bem o que é a 'tirania das sílabas', o poder de um hábito em assunto de arte, a força incoercível dos moldes acadêmicos, a subjugação do poeta a uma fôrma que era preciso arrebentar a martelo para veleidade de qualquer mudança de rumo ${ }^{103}$.

Difícil mesmo foi a tradução em obras do programa proposto pelos modernistas. As obras mais significativas são aquelas que conseguiram convergir o projeto estético com o ideológico, revelando que a ruptura na linguagem correspondia ao momento histórico vivido e propiciava um ajuste na sociedade. Como exemplo temos Macunaíma, de Mário de Andrade e Poesia Pau Brasil, de Oswald de Andrade.

Apesar da existência da denúncia de um Brasil arcaico, não há uma consciência formada sobre a necessidade de uma revolução. A implementação do capitalismo, a ascensão da burguesia e o avanço industrial ao longo dos anos 20 encontram no decênio de 30 um novo panorama político. A luta ideológica fortalece-se em todo o mundo; a consciência da luta de classes e da necessidade da Revolução penetra não apenas na sociedade como também na literatura da época.

Essa condição político-social permite que o projeto ideológico do Modernismo ganhe força; durante a década de 30, as discussões giram em torno da função da literatura, do

${ }^{103}$ RICARDO, Cassiano. Viagem no Tempo e no Espaço, Rio de Janeiro: José Olympio, 1970. p. 33. 
papel do escritor, da denúncia dos problemas sociais e das ligações da ideologia com a arte. Antonio Candido afirma que:

Na fase de consciência de país novo, correspondente à situação de atraso, dá lugar, sobretudo, ao pitoresco decorativo e funciona como descoberta, reconhecimento da realidade do país e sua incorporação ao temário da literatura. Na fase de consciência do subdesenvolvimento, funciona como presciência e depois consciência da crise, motivando o documentário e, com o sentimento de urgência, o empenho político ${ }^{104}$.

Surgem então, na década de 30 - fase de pré-consciência de país subdesenvolvido -, os ensaios históricos e sociológicos, o romance regionalista e de denúncia, a poesia militante e de combate, distanciados da linha de experimentação característica da primeira fase modernista. A cultura, antes pertencente à classe da aristocracia, passe a ser considerada como um direito de todos, já que a politização e a conscientização ganham destaque na ênfase dada ao projeto ideológico do Modernismo.

A tomada de consciência ideológica por parte dos intelectuais na década de 30 e a nova organização social permitiu o estabelecimento de uma nova correlação que se estreitou ao longo dos anos 40: de um lado, o intelectual e o artista; de outro, a sociedade e o Estado. O primeiro grupo carregava em si o conceito de opositor, adotando uma posição crítica em face às arbitrariedades do Estado e à mentalidade conservadora.

Entretanto, sabemos que essa oposição não estava nitidamente delineada e o poder extremo adquirido pelo Estado gerou uma série de paradoxos na relação intelectual-Estado. Antonio Candido afirma que isso aconteceu principalmente porque

[...] O intelectual e o artista foram intensamente cooptados pelos governos posteriores a 1930, devido ao grande aumento das atividades estatais e às exigências de uma crescente racionalização burocrática. Nem sempre foi fácil a colaboração sem submissão de um intelectual, cujo grupo se radicalizava, com um Estado de cunho cada vez mais autoritário ${ }^{105}$.

104 CANDIDO, Antonio. "Literatura e Subdesenvolvimento". In: A Educação pela Noite \& Outros Ensaios. $3^{\mathrm{a}}$ ed. São Paulo: Ática, 2000. p. 158.

105 CANDIDO, Antonio. "A Revolução de 1930 e a Cultura". In: Outros Ensaios. $3^{\mathrm{a}}$ ed. São Paulo: Ática, 2000. p. 195. A Educação pela Noite \& 
Essas mudanças político-sociais influenciaram a constituição da crítica brasileira. Afrânio Coutinho aponta que a crítica literária exercida entre 1922 e 1940 é a chamada crítica do artista; ou seja; "todos são críticos e ninguém o é. [...] A crítica é impessoal e anônima, crítica sobretudo de manifestos, que é a crítica coletiva por excelência" ${ }^{106}$. Esse tipo de crítica marcou, principalmente, a década de 20 e início de 30, com a composição de diversas revistas, boletins e grupos fundados por intelectuais que se destacavam no conjunto.

A crítica legitimamente "modernista", isto é, praticada por escritores formados depois de 1922, reconhecidos pela qualidade individual de crítico e que não tivessem que se adaptar à modernidade, surge apenas por volta de 1940. É a partir daí que reflexões críticas ganham seriedade e método para se tornar crítica literária.

Não temos como principal objetivo analisar de forma profunda o movimento e a crítica modernista, mas sim apresentar um panorama das mudanças ao longo das décadas de 20 e 30 para entender de que maneira a produção teatral reagiu às transformações propostas pelo Modernismo. Partiremos da dicotomia entre projeto estético versus projeto ideológico proposto por Lafetá para analisar as iniciativas que fugiam do padrão proposto na época, ou, como observa Tania Brandão, que escapavam à máquina de repetir estabelecida na cena nacional.

\subsection{O Teatro da Década de 20 e Projeto Estético do Modernismo}

Algumas manifestações teatrais da década de 20, sejam elas em forma de crítica ou de criação artística, aproximam-se do projeto estético do Modernismo na medida que buscam o novo por meio da renovação das formas. Mesmo que essas transformações atinjam de uma certa maneira a composição do conteúdo, elas partem originalmente da alteração das fórmulas. A intenção era expressar valores nacionais com formatos essencialmente brasileiros, de modo que o nosso povo se identificasse com essas novas formas de representação. Entre os intelectuais que mais se destacaram ao longo de nossa pesquisa, selecionamos aqueles que de alguma forma contribuíram para as primeiras tentativas de

\footnotetext{
${ }^{106}$ COUTINHO, Afrânio.Op.cit. p. 598.
} 
modernização e que buscavam no estético uma forma de projetar um novo conceito de teatro.

O momento sócio-histórico ainda era propício para a defesa e expressão da consciência estética do movimento. Em 1940, quase duas décadas depois da Semana de Arte Moderna, a Revista do Brasil lança um inquérito sobre "As tendências atuais da literatura brasileira", pelo qual alguns importantes nomes do movimento discorrem sobre os novos rumos da literatura, o espírito modernista e as influências estrangeiras que predominavam na época. Uma outra questão - a primeira e talvez a mais relevante do inquérito - questiona se o modernismo representou afinal um movimento crítico ou criador. Entre as respostas, destacamos a de Mário de Andrade:

O movimento modernista se originou essencialmente de um estado de nãoconformismo. Em sua transcendência ele foi, portanto, uma força revolucionária, e se identificou com as outras forças revolucionárias que, aberta ou caladamente, se desenvolviam no país e no mundo. [...] Logicamente, deveria ter sido um movimento de caráter crítico. As nossas circunstâncias sociais, a falta de cultura universitária ou tradicional principalmente, e o desinteresse geral pela discussão das idéias, exigiram que ele se tornasse um movimento criador. Mas a necessidade crítica interferiu, também logicamente, nessa criação, e a deformou. E o movimento se tornou, por excelência, experimentalista ${ }^{107}$.

Destacamos em nossa pesquisa exemplos do movimento crítico - Antônio de Alcântara Machado - e, também, do movimento criador - Álvaro Moreyra e Renato Vianna - acerca das realizações teatrais da década de 20. Essa escolha foi motivada principalmente pela quantidade de artigos, notas e citações deles e sobre eles localizados na nossa pesquisa. Buscamos aqui entender a importância dos representantes do projeto estético do nosso teatro para os intelectuais da época; apresentar suas principais iniciativas e tentar apontar suas contribuições - sejam elas de caráter criador ou, mesmo, experimentalista, como nos explicou Mário de Andrade na citação acima.

\footnotetext{
${ }^{107}$ ANDRADE, Mário de. "O Inquérito da 'Revista do Brasil' acerca das 'Tendências Atuais da Literatura Brasileira'. In: Revista do Brasil. n⿳0 22, abr. 1940. p. 107.
} 


\section{O Teatro da Bagunça e a Crítica Teatral}

Antonio de Alcântara Machado destaca-se como um dos principais colaboradores nos periódicos pesquisados. Sua participação inicia-se em 1924, com a publicação de uma crítica na revista Novíssima, intitulada 'O que eu disse a um comediógrafo nacional', e se encerra em 1932, com o texto 'Leopoldo Froes', na Revista Nova, totalizando 16 publicações em 7 periódicos diversos ${ }^{108}$.

Ao longo da década de 20, Alcântara Machado expressa sua insatisfação em relação à 'miséria do teatro nacional' por meio de diversas críticas, que em conjunto formam um verdadeiro projeto de renovação estética do teatro nacional, seguindo dois princípios do Modernismo: nacionalizar e atualizar.

O projeto de incorporar à criação teatral as propostas do movimento Modernista atualização e abrasileiramento dos temas e das formas - confundia-se, para Alcântara Machado, com a própria criação do teatro brasileiro, já que, na sua opinião, ele não existia. E inexistia pela quantidade de males de que padecia: desnacionalização, atraso técnico, repetição, ignorância da época e do meio, uniformidade, pobreza de tipos e de cenários ${ }^{109}$.

Em seu texto publicado na revista Novíssima, em 1924 - 'O que eu disse a um comediógrafo nacional' (2.3.2.2), já é possível perceber a posição de Alcântara Machado em relação ao teatro da época:

Na literatura dramática nacional há três tipos de comédias: o tipo piegas ou Flores de Sombra; o tipo caricatural ou O Simpático Jeremias e o tipo A Vida é um Sonho... que é da comédia de costumes.

Mesmo criticando a ausência de temas nacionais nos nossos palcos, ele aponta o caminho a ser seguido, ainda com a euforia da geração de 22:

\footnotetext{
${ }^{108}$ Não levamos em conta, aqui, os artigos que Alcântara Machado publicou em jornais. (Ver LARA, Cecília de. De Pirandello a Piolim: Alcântara Machado e o Teatro no Modernismo. Rio de Janeiro: INACEN, 1987). ${ }^{109}$ MATERNO, Ângela. “A Crítica Teatral de Alcântara Machado”. O Percevejo. Ano II, n. 02, 1994. p. 44.
} 
Abrasileiremos o teatro brasileiro. Melhor: apaulistanisemo-lo (sic). Fixemos no palco o instante radioso de febre e de esforço que vivemos. (...) Argumentos nacionalíssimos. Há que se importar as fórmulas, tão somente as fórmulas. As de hoje, as deste tempo, as fórmulas inovadoras e moças de Romains, de Shaw, de Pirandello, de Zimmer, de Tchapek, de Gontillon, de tantos, de tantos! Vamos! Um bocadinho de coragem e de mocidade!

É importante ressaltar o destaque dado pelo crítico ao aspecto estético da renovação. Ao dizer "há que se importar as fórmulas, tão somente as fórmulas", Alcântara Machado sustenta que a criação de um teatro essencialmente brasileiro deveria contar com argumentos e personagens extremamente nacionais; entretanto, as fórmulas deveriam ser atuais e inovadoras, as mesmas utilizadas por importantes nomes do teatro estrangeiro. Essa era a única importação que deveria existir.

Em 1926, como crítico da revista Terra Roxa de Outras Terras, Alcântara Machado apresenta seu mais completo conjunto de críticas teatrais, que, longe da observação imparcial, ataca o 'embrião informe' do teatro nacional e dita uma nova estética teatral. Ele expressa em seus artigos o desejo de redescobrir o homem brasileiro, sendo que "o critério máximo de valorização é o 'brasileirismo', bem como a falha mais rigorosamente censurada é a imitação estrangeira" ${ }^{110}$. Entenda-se aqui que imitação é uma condição completamente diferente da idéia de importação. Buscar no outro uma estética já estabelecida não pressupõe cópia exata de tudo aquilo que a composição formal implica.

É essa tensão do nacional versus o estrangeiro que move toda a argumentação dos seus artigos publicados nesse periódico. No artigo intitulado Indesejáveis (5.3.2.1), ele aponta três responsáveis pela situação de 'miséria' do teatro brasileiro: as companhias européias, os repertórios estrangeiros e a imitação do teatro francês.

Segundo o autor, a cena nacional desconhece os tipos e os temas essencialmente brasileiros, como o cangaceiro, o emigrante, o grileiro, o político, o ítalo-paulista, o industrial etc. Destacam-se apenas duas peças consideradas puramente "auri-verdes": Juriti, de Viriato Correa e Mimoso Colibri, de Armando Gonzaga. Essas peças não apresentam nenhum aspecto moderno relevante; entretanto, apesar de seguirem o padrão

${ }^{110}$ LARA, Cecília de. Klaxon \& Terra Roxa e Outras Terras: Dois Periódicos Modernistas. São Paulo: IEB, 1972. p. 40. 
das comédias de costume, elas possuem um importante traço em comum: o espírito nacionalista.

Em outro artigo intitulado Questão de Vergonha (5.3.2.3), Alcântara Machado protesta contra a iniciativa de Cláudio de Souza em realizar uma temporada teatral brasileira em Paris. Como apresentar uma temporada teatral brasileira, se o nosso teatro é imitação dos franceses? Como ele mesmo afirma, seria "apresentar produto falsificado a quem o fabrica legítimo".

A posição de Alcântara Machado pode ser melhor compreendida pelas palavras de Cecília de Lara:

Alcântara Machado tem preocupação em defender a arte brasileira, combatendo as atitudes individualistas dos que buscam a promoção pessoal mesmo em detrimento do conceito da arte brasileira no exterior ${ }^{111}$.

Essa defesa da arte brasileira pode ser constatada em seu artigo Nosso Primeiro Dramaturgo (5.3.4.1), no qual ele apresenta as qualidades do dramaturgo José Anchieta e sua busca pela "cor local", que caracterizava os personagens e as situações. Isso revela o forte caráter nacionalista de Alcântara Machado, que tinha por principal ideal a busca do "brasileirismo" na vida cotidiana do povo, incluindo a linguagem.

Um outro elemento nacional valorizado por Machado (5.3.2.1) e por Mário de Andrade (5.3.5.1) é o circo, que era considerado como a única produção dramática válida na época. Piolim ganha grande destaque e é considerado como o único artista a revelar os elementos nacionais no palco.

Já na Revista do Brasil, discutia a revolução de idéias e a renovação das formas teatrais propostas por Strindberg, Max Reinhardt, Copeau, Bragaglia e Meierhold. Além disso, argumentava contra aqueles que choravam "sentidamente e antecipadamente a morte do teatro provocada pelo cinema e pelo café-concerto" (16.3.3.2) ${ }^{112}$.

\footnotetext{
${ }^{111}$ Idem. p. 171.

${ }^{112}$ Para melhor compreender o embate de idéias gerado pelo advento do cinema e do café-concerto, ver capítulo 3.
} 
Em seu artigo publicado na revista "Movimento", intitulado Teatro no Brasil (9.3.2.1), Alcântara Machado aponta o excelente momento para a criação do teatro brasileiro e uma crítica aos modernistas:

A geração que explodiu em 22, preferindo o novo e certamente com outra sinceridade a utopia da independência à certeza da morte (parece discurso, mas é para parecer mesmo) bem poderia criar o teatro do Brasil. Aí, sim, o campo é inédito e livre. Sem regras e sem modelos. Uma bagunça. Um teatro bagunça da bagunça sairá. Ça irá?

Para ele, o 'teatro da bagunça' seria aquele no qual o público, ao invés de aprender com a crítica os valores do bom teatro, iria reconhecer-se como o "dínamo propulsor e razão de ser de um teatro que incorporasse na cena a teatralidade da cultura popular" ${ }^{113}$. A necessidade de um novo público ou da educação das platéias não seria mais um empecilho aos homens de teatro. Incorporar a realidade e os tipos nacionais à cena brasileira garantiria a presença do público e a valorização do novo e moderno teatro nacional:

A idéia de recomeçar pelo começo, a partir dos elementos mais simples, daquilo que poderíamos chamar de mínimos denominadores comuns da nacionalidade, base do 'primitivismo nativo' modernista, era o ponto de apoio que permita a Alcântara Machado fulminar a cultura oficial e sonhar com novas formas de teatro através das quais arte popular e arte erudita deixassem de se contradizer ${ }^{114}$.

O seu último artigo registrado em nosso índice foi publicado na Revista Nova em 1932, três anos antes de sua morte. Intitulado "Leopoldo Froes" (11.3.4.1), o artigo apresenta uma crítica ao senso comercial do ator, que nada acrescentou ao desenvolvimento do moderno teatro nacional:

Antes de tudo é preciso reconhecer que Froes beneficiará (como beneficiou em vida) da absoluta miserabilidade do teatro brasileiro. Num país onde não existe literatura

\footnotetext{
${ }^{113}$ RAMOS, Luiz Fernando. "Da Pateada à Apatia: O Teatro da Bagunça de Alcântara Machado e a Crítica de Teatro no Brasil”. O Percevejo, Ano II, n. 02, 1994. p. 49.

114 PRADO, Décio de Almeida. "O Teatro e o Modernismo". In: São Paulo: Companhia das Letras, 1993. p. 24. 
dramática o ator ganha uma importância excessiva. Quero dizer: fica importante por exclusão. João Caetano é um exemplo. Falar em teatro brasileiro é falar nele. Por quê? Porque a nossa história literária não registra um só autor (Antônio José da Silva é escritor português), uma só criação dramática, já não digo elogiáveis, mas simplesmente apresentáveis.

E ainda:

Depois, o senso comercial apuradíssimo. Diante dele a ganância dos empresários entregava os pontos logo de início. Froes sabia ganhar e o que ganhava guardava. Para maior garantia fez-se empresário ou sócio de empresários. Tendo a habilidade de não empregar no teatro o capital que formou com os lucros que o palco lhe deu. Essa aspiração de todo ator e diretor de companhia (João Caetano a satisfez) de possuir o seu teatro, Froes nunca teve. Nunca teve porque nele o artista é que servia o homem de negócios. E este sabia onde aplicar melhor o que o trabalho daquele rendia.

Além dos artigos de sua própria autoria, encontramos diversos textos que mencionam a importância do crítico em questão. Destacamos a resenha escrita por Valdemar Cavalcanti quando da publicação de seu livro póstumo Cavaquinho e Saxofone, organizado por Sergio Milliet e Motta Filho (16.2.2.4). É curioso observar como Alcântara Machado era visto por seus contemporâneos. Cavalcanti aponta a visão de vanguarda do "devorador de mediocridades solenes":

Não é lugar, aqui, para discutir as injustiças que Antonio de Alcântara Machado cometeu, como, de resto, os modernistas em geral, em relação a valores que não se acomodavam à escala projetada pelos renovadores, por isso mesmo - e não só por isso - rechaçados, e cuja expressão, no quadro das nossas atividades culturais, seria depois convenientemente restaurada, com as restrições e saliências necessárias. A verdade, porém, é que a atitude do escritor paulista, ditada pelas conveniências da própria política de renovação, revelou um espírito crítico dos mais alertas e penetrantes, sempre reafirmado no decurso de sua breve, porém brilhante carreira literária. 
Podemos então afirmar que Antonio de Alcântara Machado, integrante do grupo modernista que compunha a classe de 'crítica do artista', afastava-se um pouco desse grupo na medida em que não fazia críticas anônimas ou de modo coletivo. De qualquer maneira, havia sim um posicionamento forte, que embasava uma visão extremista daquilo que era ou que deveria ser o teatro nacional. O conjunto de suas críticas forma para nós, estudiosos do teatro brasileiro, um importante dossiê que revela, ainda que incompleta, uma visão de teatro moderno. Suas críticas compõem um projeto de renovação estética, que pondera e reconhece as inovações do teatro estrangeiro e que defende os argumentos nacionais na construção de um teatro, essencialmente e antes de tudo, nosso. Como pensador e divulgador ativo dos ideais de renovação, Alcântara Machado possui um lugar de destaque no processo de afirmação da cena moderna brasileira.

\section{Álvaro Moreyra e o Teatro de Brinquedo}

Com o intuito de renovar a cena nacional, alguns artistas brasileiros tinham como principal preocupação a conquista da platéia burguesa, que não ia ao teatro, oferecendo textos de melhor qualidade, que aproveitassem o modelo estrangeiro na representação de assuntos nacionais. Nomes como Álvaro Moreyra e Renato Vianna destacaram-se na década de 20 pelas propostas e tentativas que fossem de encontro ao sistema já consolidado em nossos palcos desde o século XIX, no sentido de experimentar teorias e ampliar as inovações cênicas:

Trata-se de grupos oriundos da média e alta burguesia em busca de uma expressão de arte condizente com um gosto voltado para aquilo que na época se considerava 'mais elevado'. Tais parâmetros são fixados a partir de modelos estrangeiros, já que o teatro realizado aqui e freqüentado pelas classes populares serve apenas, segundo esses grupos, para atestar nosso caráter de povo 'subdesenvolvido' e 'inculto' ${ }^{115}$.

Assim, na década de 20, aparece a proposta de um artista pertencente à elite carioca que tinha por principal objetivo organizar um teatro voltado para a própria elite, que apresentasse textos de qualidade e que se opusesse ao então considerado 'teatro popular'.

115 CAFEZEIRO, Edwaldo e GADELHA, Carmem. História do teatro brasileiro: de Anchieta a Nelson Rodrigues. Rio de Janeiro: Editora UFRJ/Funarte, 1996. p. 429. 
Assim, somando interesses pessoais com seu conhecimento prévio de manifestações teatrais francesas, italianas, russas e até japonesas, Álvaro Moreyra une-se a sua esposa Eugênia Moreyra para fundar o Teatro de Brinquedo em 1927.

Em sua conferência datada de 1925 e publicada na revista Ilustração Brasileira, com o título "Teatro que foi e que será" (14.4.2), Álvaro Moreyra apresenta as idéias de seu Teatro de Brinquedo que seria fundado dois anos mais tarde. Trechos desta conferência serão retomados em diversos artigos escritos pelo autor e em seu livro As Amargas, não...Lembranças :

Eu sempre cismei um teatro que fizesse sorrir, mas que fizesse pensar. Um teatro com reticências... Um teatro que se chamasse Teatro de Brinquedo e tivesse como única literatura uma epígrafe do velho Goethe: 'Humanidade divide-se em duas espécies, a dos bonecos que representam um papel aprendido e a dos naturais, espécie menos numerosa de entes que nascem, vivem e movem-se segundo Deus as criou...' Um teatro de bonecos? Sim. Mas supondo que nessa estação do século XX, os bonecos, de tal maneira aperfeiçoados, dessem a sensação de gente de carne, osso, alma, espírito... Por que de brinquedo? Porque os cenários imitam caixas de brinquedos, simples, infantis. Um teatro que não contrarie aquela cantiga que resume todas as histórias, todas as filosofias, todos os pontos de vista:

'Les petites marionettes

Font, font, font

Trois petits tours

et puis s'en vont'.

Partindo desta proposta, o Teatro de Brinquedo estréia com a peça Adão, Eva e outros membros da família, escrita por ele mesmo em 1925. Essa peça possui seu valor histórico por apresentar temas e personagens completamente novos na cena nacional. Com uma linguagem coloquial e objetiva, o autor: 
[...] desmonta contradições da sociedade capitalista que permitem a um mendigo e um ladrão transformarem-se em respeitáveis figuras da classe dirigente e a uma mulher indefinida, primeiro amante de um e depois do outro, tornar-se grande artista ${ }^{116}$.

Entretanto, apesar do tom antinaturalista da peça, que apresenta um processo de despersonalização expressionista ao utilizar máscaras ou marionetes no lugar de personagens, o gosto do autor pelo jogo de palavras e pelo trocadilho, torna o enredo rarefeito e diluído, no qual as palavras em si têm mais relevância do que a ação dramática $^{117}$.

Apesar de receber críticas positivas após a estréia de sua peça, o grupo não conseguiu manter o mesmo sucesso nas peças seguintes, influenciadas negativamente pela falta de planejamento de seus idealizadores.

Décio de Almeida Prado aponta que a ausência de um conhecimento específico do palco e de uma consciência estética mais clara e definida das inovações faz da experiência do Teatro de Brinquedo "uma diversão amadora inteligente" 118.

Mesmo assim, Álvaro Moreyra não esmoreceu. Dois anos depois da estréia de Adão, Eva e Outros Membros da Família, o autor se une novamente a René de Castro na formação do "Cenáculo dos Amigos da Arte", na tentativa de se criar o teatro de avantgarde (21.3.3.2). Seu novo fracasso foi registrado por uma nota de Mário Nunes que, desapontado com o não-apreço do público em relação às peças de Álvaro Moreyra, critica os empresários Procópio Ferreira e Paschoal Segretto por não arriscarem suas bilheterias ao experimentar e inovar suas realizações (21.3.3.4).

Antes de montar sua Companhia, que levaria seu nome, em 1937, Álvaro Moreyra continuou a escrever artigos voltados para o debate sobre a criação de um teatro estritamente nacional. Partidário agora das idéias da Antropofagia, o autor revela em uma entrevista publicada na Revista de Antropofagia (8.4.1) suas novas idéias sobre a composição teatral, dando destaque à habilidade do ator em cena:

\footnotetext{
${ }^{116}$ OSCAR, Henrique. O Teatro e a Semana de Arte Moderna de São Paulo. Rio de Janeiro, 1985. p. 19.

117 FARIA, João Roberto. "Álvaro Moreyra: Poesia e Teatro no Modernismo". In: O Teatro na Estante. São Paulo: Ateliê Editorial, 1998. p. 111.

${ }^{118}$ PRADO, Décio de Almeida. Op. cit. p. 27.
} 
Teatro Sem Nome porque se compõe de 'artistas' que sabem o que querem, não acredita em ensaiadores. Lá não há meio termo. Nem esforçados. Desses que a gente conserva em intenção à boa vontade. (...) Teatro Sem Nome. Porque o que interessa é o teatro... A ordem, o método, a disciplina anulam a expressão que só o instinto sabe criar. E neste ponto mais uma identidade absoluta com a Antropofagia. O instinto acima de tudo é também um principio do Teatro Sem Nome.

Talvez seu desejo de renovação tenha tido muito mais valor do que suas concretas realizações, voltadas para a inovação cênica do teatro nacional. O autor conquistou seu lugar de destaque como intelectual presente e ativo, promovendo importantes discussões sobre os acontecimentos teatrais, principalmente na década de 30, quando foi editor da revista Dom Casmurro. É notável o quanto suas concepções acerca das transformações que deveriam ocorrer no teatro nacional apresentavam preocupações de caráter moderno; entretanto, não havia em Álvaro Moreyra uma linha mestra que baseasse seu trabalho e que se desenvolvesse ao longo dos anos em busca de uma concepção madura do espetáculo. Com o insucesso do Teatro de Brinquedo, encontramos o autor engajado com a Antropofagia, onde defendia o instinto acima da ordem, do método, da disciplina, como se a representação transcendesse e ignorasse a técnica.

Na década seguinte, Álvaro Moreyra organiza uma nova companhia e faz uso das convenções do 'antigo teatro' para a composição do elenco, sustentado em cena pelo ponto. Em 1936, junto com outros dois diretores, ele ganha o subsídio oferecido pelo Ministério da Educação para montar essa companhia, o que gerou muita polêmica entre os interessados pelo patrocínio. Registramos essa informação por meio de um texto de Brício de Abreu - assinando como Ludo na revista Dom Casmurro - intitulado Uma Questão Ruidosa (24.3.2.1). Apesar de não ter muito apreço pelo ministro Capanema, o crítico reconhece sua escolha acertada e defende seu colega de edição:

Capanema nomeia uma comissão para decidir quem ganharia o financiamento. São selecionadas as companhias de Jaime Costa e Álvaro Moreyra. A terceira vaga ficou entre Álvaro Pires e Serra Pinto. Houve então muita reclamação e ofensa a Álvaro Moreyra. Álvaro Pires e Serra Pinto achavam que a concessão dada a Álvaro Moreyra para a organização de uma companhia não tinha cabimento, era protecionismo, pois 
faltava ao dito senhor competência para o teatro, e daí a terem chegado ao insulto a um homem que é, queiram eles ou não, uma competência teatral mil vezes a de ambos reunidos.

Apesar da polêmica, Álvaro Moreyra forma seu elenco com Eugenia Álvaro Moreyra, Itália Fausta, Adacto Filho, entre outros, e passa a contar com os encenadores Santa Rosa e Oswald de Andrade Filho. Tem sua estréia em São Paulo, realiza uma longa temporada no Rio de Janeiro e como parte do contrato com o ministério viaja em excursão para o Rio Grande do Sul ao final de 1937 (24.2.1.26).

Entre as peças levadas em cartaz por sua Companhia, registramos as seguintes: $O$ Sol de Osíris, de Heitor Modesto como peça de estréia em 02 de setembro; $O$ Rio, de Júlio Tavares, pseudônimo de Carlos Lacerda (já perseguido pela polícia) em 16 de setembro; $O$ Noviço, de Martins Pena em 07 de outubro; A Comediante, comédia de Chrysanthème em 14 de outubro; Ásia, de Lenormand em 21 de outubro; e Volúpia de Honra, de Luigi Pirandello em 05 de novembro. Todas essas peças foram levadas ao palco do Teatro Regina no ano de 1937. Registramos as datas de cada estréia para ficar claro o acelerado ritmo das realizações de sua Companhia, que devia seguir um estrito calendário do ministério.

É curioso observar a contraditória relação que Álvaro Moreyra estabeleceu com o poder em vigor na época em questão: o Estado Novo. Ao mesmo tempo em que dependia dos subsídios desse governo violento e autoritário para sobreviver, utilizava recursos para mascarar a verdade para se aproximar dos 'procurados-políticos'. Por isso, a identidade do autor Júlio Tavares não poderia ser revelada. Percebemos, por meio de uma crítica publicada após a estréia da peça $O$ Rio, que esta não era a real identidade do autor:

A Companhia de Arte Dramática, que é assim que se denomina o grupo organizado pelo poeta Álvaro Moreyra, representou, ontem, no Regina, mais uma peça das destinadas a completar o programa de educação artística ideado pelo Sr. Capanema, que conseguiu, com grande esforço, uma verba para ver se é possível levantar entre nós o teatro nacional. A peça chama-se $O$ Rio e como autor se apresenta Júlio Tavares, que 
segundo tivemos notícia, não passa de um pseudônimo com que se esconde um dos novos, ávido de uma tentativa na literatura dramática ${ }^{119}$.

Ainda um outro fato pode ser utilizado como exemplo dessa relação contraditória: a prisão de Eugênia, sua esposa, ocorrida pouco tempo antes do anúncio da concessão da Companhia Álvaro Moreyra. Eugenia foi libertada antes da estréia da companhia, mas sua prisão deixou um novo questionamento quanto à coerência de Álvaro: “o mesmo regime que prende a esposa financia as peças que o marido monta com auxílio dos filhos, que sempre fizeram parte da equipe de produção. O Álvaro Moreyra que nunca aceitava trabalhar para revistas que o desagradassem politicamente não titubeou em aceitar $o$ dinheiro do governo Vargas para montar suas peças" $" 120$.

Não pretendemos nos deter aqui nas razões e contradições de Álvaro Moreyra. Nossa intenção foi mostrar que suas realizações teatrais eram sempre inconstantes e não seguiam um padrão unificado e lógico, que reunisse os preceitos do teatro moderno. Se analisarmos suas realizações da década de 30 , adentramos em uma nova abordagem - a do projeto ideológico do modernismo - que envolveria outros critérios de análise. Optamos por incluir Álvaro Moreyra na esfera do projeto estético do movimento por entender que suas iniciativas não se consolidam como uma concepção completa e não atingem a complementaridade dos aspectos formais e ideológicos na realização de sua arte. Portanto,

parece justo [...] afirmar que a brincadeira moderna de Álvaro Moreyra não chegou a propor mudanças de grande realidade, pois o perfil teatral de seu idealizador estava longe de ser nítido. O ideário que defendeu [...] é vago, amplo, indefinido, incorporando um vasto rol de nomes do teatro universal contraditórios entre si, situação que indica no mínimo falta de clareza na formulação de uma proposta estética. A montagem de estréia do Teatro de Brinquedo juntou personalidades do gasto teatro profissional da Praça Tiradentes, gente da sociedade, amadores, em uma mistura igualmente heterogênea e ambígua ${ }^{121}$.

\footnotetext{
119 Apud: FERMINO, Ricardo Lísias Aidar. No Palco, no Papel e na Prisão: uma Biografia (seguida de antologia) de Álvaro Moreyra). Tese de Doutorado. São Paulo: FFLCH/USP, 2005. p. 101.

${ }^{120}$ FERMINO, Ricardo Lísias Aidar. Op. cit. p. 108.

${ }^{121}$ BRANDÃO, Tania. Op. cit. p. 24
} 
Ambíguo, indefinido e vago. Assim podemos definir o projeto de renovação proposto por Álvaro Moreyra. De qualquer forma, ele conquistou uma posição notória na história do teatro brasileiro por ter sido um pensador, debatedor e divulgador de mudanças, reconhecidas como necessárias para a evolução da cena nacional.

\section{Renato Vianna e a Batalha da Quimera}

Após estrear no teatro, em 1918, com a autoria do drama Voragem, levado à cena pela Companhia Dramática Nacional, com representação de Itália Fausta e a criação de Salomé (1919) e Fantasmas (1920) para o mesmo elenco, Renato Vianna une-se com Ronald de Carvalho e Villa-Lobos para fundar a Batalha da Quimera, definida por Gustavo Dória como "uma organização que tentava mostrar pela primeira vez, no Brasil, o teatro de síntese, de aplicação da luz e do som como valores dramáticos, da importância dos silêncios, dos planos cênicos e da direção" ${ }^{122}$. A consciência desses elementos modernos é resultado de seu conhecimento literário somado às influências de Ibsen, Antoine, J. Copeau e Stanislawski, refletidas em sua atuação como ator, metteur-en-scène e professor.

A apropriação dessas teorias pode ser observada na sua concepção cênica e na abordagem que dava ao texto dramático:

As rubricas das peças de Renato Vianna indicam o significado que atribuía às pausas e aos silêncios, como processo de introspecção do palco, e sabe-se do escândalo que provocou ao dar pela primeira vez as costas ao público, em meio a uma réplica, na procura de maior realismo cênico ${ }^{123}$.

Partindo da consideração de Sábato Magaldi, localizamos algumas rubricas das peças de Renato Vianna que revelam seu caráter experimentalista e sua preocupação com os silêncios, a iluminação e a profundidade de seus personagens. Entre elas, optamos por citar duas: a primeira da peça A última conquista e a segunda da peça Fogueiras da carne ${ }^{124}$ :

\footnotetext{
${ }^{122}$ DORIA, Gustavo. Moderno teatro brasileiro. Rio de Janeiro: SNT/MEC, 1975. p. 14.

${ }^{123}$ MAGALDI, Sábato. Panorama do Teatro Brasileiro. 4.ed. São Paulo: Global, 1999. p. 196.

${ }^{124}$ VIANNA, Renato. Sexo e Deus. Obras Completas - 2 vol. Rio de Janeiro: A Noite, 1957. p. 182 e 66.
} 
Um silêncio. Borba Netto aproxima-se da janela por onde o luar entra como uma faixa do céu. Dentro, o piano, a romanza.

E neste labirinto de confissões imperativas, Gabi como que foi se sentindo apaziguar da sede devoradora de sua alma... Mas o fantasma da realidade consciente surge subitamente diante dela.

A Batalha da Quimera estreou com a representação de uma peça de sua autoria, $A$ Última Encarnação de Fausto, que não agradou nem o público nem a crítica. Apesar de suas idéias inovadoras, a qualidade de seus textos não atingia o nível esperado, o que se revelou fator determinante para o não prosseguimento de sua iniciativa. Entretanto, Renato Vianna continuou a explorar seus ideais em diversas realizações, como a formação da Companhia Colméia, ao lado de Simões Coelho em 1924 (2.4.2), Caverna Mágica, em 1927, com Paschoal Carlos Magno como intérprete da peça Abat-jour; o Teatro Arte de 1932 com a participação de Dulcina de Morais; e o Teatro-Escola, em 1934, com o apoio de autoridades para realizar a formação de novos atores.

Localizamos, nas páginas da revista Fon Fon de 1935, um texto do autor que aborda, após anos de experiências e experimentações, suas crenças em relação à arte teatral. É possível perceber que, para Renato Vianna, a religiosidade, a fé e a intuição compõem a transcendência e intuição do artista, desvinculando-o da técnica e/ou método (13.3.4.7):

Vejo na estética uma forma de conhecimento - para mim a suprema forma do conhecimento e não uma simples forma de divertimento. [...] A verdade é uma só: é a estética, síntese do conhecimento pela intuição. [...] Creio que o indivíduo só esteticamente, pela arte, pode libertar-se da miséria humana, elevando-se à altitudes espirituais da pura contemplação e livrando-se da corrente das paixões, necessidades e desejos [...] A Arte é o próprio mundo da transcendência. Não admito arte sem profundeza mística, sem um sentido religioso da vida e do ser. Não admito obra de arte sem o espírito do ideal. Confundo fé e a inspiração com a intuição em si mesma atuando através o artista. [...] É o próprio Bem e o próprio Mal - as duas forças dramáticas da vida. E é "toda a Arte”. É a Pintura, é a Poesia, é a Escultura, é a Dança, é a Música. 
A crítica da época sempre depositou em Renato Vianna uma confiança da renovação tão aguardada entre os intelectuais modernistas e, por isso, atribuía valor às suas iniciativas e as destacava nas críticas da época. Mário Nunes, em seu artigo intitulado "Teatro Nacional", publicado na revista Ilustração Brasileira (14.3.2.6), destaca a importância das peças A última encarnação de Fausto, Salomé e Os Fantasmas na tentativa de nacionalizar os palcos brasileiros. Já Walter Benevides, em seu artigo "Teatro Brasileiro”, publicado na revista Festa (6.3.2.1), revela a esperança depositada no trabalho de Renato Vianna que ainda estrearia com sua Caverna Mágica:

Até o momento em que escrevo, Renato Vianna não estreou com a sua companhia de amadores. Mas dar-nos ha ele alguma cousa (sic) de verdadeiramente novo? Como precisamos!

Mesmo com toda esperança depositada em seu trabalho, Renato Vianna não encontrou meios de expandir suas iniciativas, não alcançando a ruptura necessária do sistema vigente até então. Notamos que a mesma ambigüidade e incoerência observadas nas realizações de Álvaro Moreyra podem ser destacadas nas críticas acerca das considerações de Renato Vianna. Em um primeiro momento, registramos o crítico teatral Oscar D’Alva, em 1934, notificando a estréia de sua peça A Última Conquista no Teatro Cassino. Para o crítico, o autor se consagrou junto à Associação dos Artistas Brasileiros e com a propaganda do seu Teatro-Escola, com a participação de Olga Navarro, Teixeira Pinto, João Barbosa, entre outros (13.3.5.16). Isso revela que, mesmo com o passar dos anos, os críticos teatrais continuavam a respeitar e a valorizar o seu trabalho. A sustentação de seus ideais modernos se desfaz quando Renato Vianna volta a se adequar às condições teatrais da época e concilia com os padrões dominantes para estabelecer sua forte relação com o mercado. Isso pode ser exemplificado com a crítica feita, em 1944, pelo próprio Vianna contra o trabalho de Santa Rosa junto a Os Comediantes, acusando-o de ser apenas um cenarista (16.3.2.12). Não cabe aqui detalhar os desdobramentos desse comentário, mas sim destacar a opinião contrária de Renato Vianna ao trabalho daquele que obteve seu lugar de destaque na história do teatro nacional como um dos primeiros cenógrafos que fez uso da concepção moderna do espetáculo em suas realizações. 
A rigor, sua densidade aparece muito mais como ideário - seja na concepção geral dos projetos que defendeu, seja em função do seu desejo de, como dramaturgo, tratar das contribuições de Freud para o estudo do ser humano, apesar dos limites de realização revelados em seus textos, do que em virtude da posição efetiva de um teatro moderno 125.

De qualquer modo, acreditamos em seu reconhecimento como homem de teatro, tanto pelas tentativas de realizar em palcos nacionais inovações apreendidas por meio dos modelos estrangeiros, quanto pela defesa da existência de uma escola como preparo indispensável ao ator. Ainda que incompleto e sem expressão no combate aos padrões dramatúrgicos da época, Renato Vianna conquistou o respeito dos críticos e artistas da época, figurando por diversas vezes em notas, críticas e seções de fotos das revistas pesquisadas. Juntamente com Álvaro Moreyra, era considerado um grande inovador do teatro brasileiro, como observamos no depoimento de Paschoal Carlos Magno ao voltar de sua viagem à Europa:

Naturalmente, é preciso não esquecer que antes de nosso retorno ao Brasil, algumas pessoas isoladas haviam realizado obras gigantescas e que, neste país onde a memória nacional não existe, esses homens de teatro foram duramente esquecidos, sendo a sua lembrança mutilada. Eu me refiro, por exemplo, a esses homens que eu considero extraordinários na história do teatro brasileiro, que foram Álvaro Moreyra e Renato Vianna ${ }^{126}$.

\section{Flávio de Carvalho e o Teatro da Experiência}

Vale ainda mencionar que a intervenção de Flávio de Carvalho, com seu Teatro da Experiência, foi quase que ignorada pelos críticos da época. Talvez por ter sido uma iniciativa que ocorreu nos palcos da cidade de São Paulo, apenas uma pequena nota no Boletim de Ariel de 1933 destacou a estréia do autor com a peça Bailado do deus morto, resultado da iniciativa do Clube dos Artistas Modernos. Sem indicação de autoria, a nota afirma que esta será a primeira tentativa de se modernizar o teatro brasileiro e ainda

\footnotetext{
${ }^{125}$ BRANDÃO, Tania. Op. cit. p. 25.

${ }^{126}$ MAGNO, Paschoal Carlos. "Teatro de Estudante”. Dionysos. Rio de Janeiro: SNT, n. 23, 1978. p. 03.
} 
anuncia a próxima encenação do grupo com $O$ Homem e o Cavalo, de Oswald de Andrade (22.2.1.1).

No mesmo periódico, foi publicada, alguns meses depois, uma crítica escrita por Jorge Amado acerca das qualidades artísticas da peça do autor antropofágico. É por meio dessa crítica que descobrimos que a censura havia baixado as portas do Teatro da Experiência, proibindo assim a continuidade da peça de Flávio de Carvalho e a não realização da peça de Oswald de Andrade. Jorge Amado ainda conclui com a seguinte afirmação: "Terminou o palhaço da burguesia. Começou o casaca de ferro da revolução proletária" (22.2.2.2).

A conceituação teatral de Flávio de Carvalho - talvez tão radical quanto Oswald de Andrade - não encontrou caminhos livres da censura para suas experiências. Sua nãoadequação ao mercado o deixou não apenas fora da cena, mas também fora das críticas e discussões acerca do teatro vigente, pelo menos no conjunto das revistas aqui pesquisadas $^{127}$.

\subsection{Projeto Ideológico do Teatro Nacional: O Caminho da Modernização}

O advento da década de 30 encerra a fase heróica do modernismo e inicia a fase de reflexão ideológica, na qual a cultura deixa de ser privilégio de poucos e passa a ser um direito de todos. As mudanças na organização do pensamento político e social também marcam o decênio de 30; o fortalecimento da luta ideológica se expande pelo mundo inteiro. No Brasil, há o crescimento do Partido Comunista, a organização da Aliança Nacional Libertadora, da Ação Integralista, da ascensão de Getúlio Vargas e de seu populismo trabalhista. Agora, a consciência da luta de classes penetra por todas as áreas, inclusive na literatura.

O fortalecimento da consciência política transforma o otimismo da visão de país novo em uma pré-consciência pessimista de país subdesenvolvido que já não se enquadra nos mesmos moldes da década anterior. Assim:

\footnotetext{
${ }^{127}$ Sobre Flávio de Carvalho ver: J. TOLEDO. A Origem Animal de Deus - O Bailado do Deus Morto. São Paulo: Difusão Européia do Livro, 1973. e J. TOLEDO. Flávio de Carvalho: o Comedor de Emoções. São Paulo: Brasiliense e Campinas: Ed. da Unicamp, 1994.
} 
Enquanto nos anos vinte o projeto ideológico do Modernismo correspondia à necessidade de atualização das estruturas, proposta por frações das classes dominantes, nos anos trinta esse projeto transborda os quadros da burguesia, principalmente em direção às concepções esquerdizantes (denúncias dos males sociais, descrição do operário e do camponês), mas também no rumo das posições conservadoras e de direita $^{128}$.

É importante destacar que tanto o projeto estético quanto o ideológico co-existem nas décadas modernistas; as condições políticas de cada período determinavam a ênfase de cada fase. $\mathrm{Na}$ década de 30 , o projeto ideológico do movimento é empurrado para o primeiro plano, o que gera novas problemáticas e novas abordagens das produções artísticas.

A 'politização' dos anos trinta descobre ângulos diferentes: preocupa-se mais diretamente com os problemas sociais e produz os ensaios históricos e sociológicos, o romance de denúncia, a poesia militante e de combate. Não se trata mais, nesse instante, de 'ajustar' o quadro cultural do país a uma realidade mais moderna: trata-se de reformar ou revolucionar essa realidade, de modificá-la profundamente, para além (ou para aquém...) da posição burguesa ${ }^{129}$.

Pretendemos, então, entender de que modo essa mudança de ênfase atingiu as produções teatrais, que contribuíram de algum modo ao processo de afirmação do teatro moderno brasileiro. Além de considerar a posição da crítica e o processo de expansão da cultura, analisaremos também a implementação de um novo sistema político - o Estado Novo - e seus desdobramentos frente à produção teatral do período. Partiremos das contribuições de Oswald de Andrade enquanto dramaturgo e abordaremos as iniciativas do Teatro do Estudante e d'Os Comediantes como parte do processo desencadeado na década anterior e que culmina com a representação de Vestido de Noiva, em 1943.

\section{O experimentalismo de Oswald de Andrade}

Por meio de uma constante pesquisa em torno de uma estética mais autêntica, que expressasse de maneira provocativa os problemas de uma sociedade marcada pela

${ }^{128}$ LAFETÁ, João Luiz. Op. cit. p. 29.

${ }^{129}$ Idem. p. 30. 
decadência econômica da aristocracia cafeeira e pela ascensão de uma burguesia industrial capitalista, Oswald de Andrade rompeu com as velhas formas e com os tradicionais conteúdos que figuravam na literatura dramática da época.

Entretanto, "a audácia da concepção, o ineditismo dos processos, o gênio criador"130 do autor, apesar de conferirem à sua obra uma posição de destaque no teatro brasileiro, não permitiram a concretização cênica das peças que escreveu, já que estas iam além dos limites tradicionais do palco.

O Rei da Vela - escrita em 1933, mas encenada somente em 1967 - apresenta importantes inovações formais e de caráter experimentalista juntamente com uma forte crítica ao Brasil, que tentava se industrializar, trazendo à tona a crise do capitalismo e da família. Mesmo depois de 30 anos, seu vanguardismo político e estético revela-se surpreendente e atual, tornando-se um marco com a representação do grupo Oficina.

O Homem e o Cavalo (1934) e A Morta (1937) também se destacam pela audácia ideológica e pela renovação dos processos criadores da linguagem, que se revelaram estar muito à frente de seu tempo. A estrutura do teatro da época jamais permitiria a compreensão dos ousados cenários, figurinos e intérpretes necessários para a materialização do espetáculo oswaldiano. Além dos motivos morais, os motivos políticos também contribuíram para a não representação das peças de Oswald, que encontraram na censura da ditadura do Estado-Novo mais um obstáculo.

Poucos intelectuais arriscaram-se ao escrever sobre a obra de Oswald de Andrade poucos talvez a tivessem compreendido. Em nossa pesquisa, destacamos dois grandes intelectuais que discorreram sobre as ousadas peças oswaldianas: Manuel Bandeira e Graciliano Ramos.

O primeiro, em um artigo intitulado O Livro, de 1937 (24.3.2.16), escreve uma crítica teatral sobre as peças A Morta e O Rei da Vela. Bandeira aponta que apesar de seus dons de invenção, de imaginação, de sátira, de jogo verbal, que "põem o leitor num estado de perpétua surpresa”, não há uma correlação entre sua intenção social, política e a sua natureza profunda, que é de um poeta. Para Bandeira, "na direção que tomou a sua obra, a aterrissagem parece-lhe difícil”. Sua opinião pode ser melhor compreendida no seguinte trecho:

\footnotetext{
${ }^{130}$ MAGALDI, Sábato. Op. cit. p. 204.
} 
A poesia da Morta é a mais intensa que Oswald já fez. Infelizmente, ela não poderá ser entendida pelos que mais precisariam dela. Creio que Oswald faz um pouco o jogo dos turistas, da polícia, "das empresas funerárias mais dignas, como a imprensa, a política" quando transporta o conflito entre mortos e vivos para aquela estratosfera de iluminações poéticas. Os turistas se divertem. Os soldados, os marinheiros não entendem. E a polícia acaba pondo os cremadores heróicos na cadeia. Este senão, que restringe o alcance social da Morta, tão bela obra como obra-de-arte em si, é bem menos sensível em $O$ Rei da Vela. Aqui o avião de Oswald toma os primeiros contatos com o campo de aterrissagem. Com as súbitas guinadas de quem, em suma, gosta é do "loopings", dos parafusos, das folhas mortas. Oswald-poeta versus Oswald-cremador. Quando os dois um dia se entenderem, teremos em fim a obra-prima do Brasil esquerdo.

Graciliano Ramos, em seu texto O Teatro de Oswald de Andrade, de 1939 (24.3.4.12), também aponta a ousadia das peças do autor, mas desaprova a maneira pela qual critica a sociedade, já que muitos não compreenderão e aqueles que entenderem, se ofenderão.

Ambos ressaltam os valores artísticos das peças de Oswald de Andrade, mas apontam o mesmo senão: a sociedade tal como ela está organizada, ainda em fase de transformação, não compreenderia a proposta temática das peças por conta da complexidade da estrutura e da linguagem utilizadas. A restrição ao alcance social das peças de Oswald revela uma organização político-social despreparada para a convergência entre projeto estético e ideológico atingido pelo autor. Pela data de publicação dos artigos mencionados acima, respectivamente 1937 e 1939, podemos assumir que a 'restrição ao alcance social' estaria ligada tanto ao controle e à censura do Governo quanto ao despreparo da platéia.

Além da questão política, havia também dificuldades em relação à montagem de suas peças. Ao romper a linguagem e a forma artificial e acadêmica e ao quebrar as concepções ideológicas passadistas, Oswald de Andrade não encontra eco nas possibilidades práticas das companhias da época, que permitiriam a encenação de suas peças.

Tanto na década do movimento modernista como na de 30, a hegemonia do nosso palco estava nas mãos dos atores. Leopoldo Froes e Procópio Ferreira eram os astros 
maiores daquele tempo, que conheceu a figura do ensaiador, mas não a do encenador, como existia na Europa desde fins do século XIX. Abelardo I é um excelente papel para um grande intérprete, mas está no meio de idéias e preocupações que exigem a coordenação de um diretor. A perspectiva única do intérprete não abarca o universo completo de $O$ Rei da Vela. E $O$ Homem e o Cavalo e A Morta são peças que dependem quase totalmente do encenador. [...] O teatro de Oswald pedia a encenação e não apenas o primeiro ator ${ }^{131}$.

Suas peças, que iam além do projeto estético, não foram levadas à cena na década de 30, mas, certamente, garantiram a Oswald de Andrade a posição de precursor da dramaturgia moderna. Sua dramaturgia possui uma posição de destaque até hoje devido à suas inovações formais, na busca de construir uma nova linguagem; às inovações cênicas, na complexa elaboração e estruturação de suas peças; e às inovações temáticas, levando ao palco a questão da luta de classes, da apatia da sociedade e do eterno embate entre a tradição e a modernidade.

\section{O Teatro do Estudante}

Idealizado por Paschoal Carlos Magno ao voltar de sua viagem à Europa, o Teatro do Estudante surge, em 1938, com o intuito descobrir vocações para o palco por meio de orientação técnica aos atores e divulgar e ampliar o movimento de renovação que então se delineava. Reunindo estudantes que ajudassem a desenvolver um teatro de qualidade, Paschoal trouxe à cena nacional importantes inovações que direcionariam de forma definitiva o nosso teatro rumo à modernidade. A valorização do diretor e do cenógrafo como critérios essenciais na composição de um espetáculo, bem como a supressão do ponto e a imposição da língua 'brasileira' podem ser consideradas como algumas de suas principais contribuições.

Romeu e Julieta, de Shakespeare, foi escolhida para a estréia do grupo, com uma tradução inédita de Onestaldo de Pennafort. Como afirma Gustavo Dória, "pela primeira vez lançar-se-ia mão de uma tradução expressa para um determinado espetáculo e tendo ainda a assiná-la um poeta de notória importância" ${ }^{132}$.

\footnotetext{
${ }^{131}$ MAGALDI, Sábato. Teatro da Ruptura: Oswald de Andrade. São Paulo: Global, 2004. p. 170.

${ }^{132}$ DORIA. Gustavo. Op. cit. p. 49.
} 
$\mathrm{Na}$ concepção de Paschoal Carlos Magno, a presença de um diretor de cena era imprescindível; para ele, o diretor tinha por obrigação ensaiar o texto, unificando-o no trabalho de cenógrafo e com o iluminador, criando assim toda uma concepção unitária de espetáculo. Esta era a grande novidade: a consolidação, no teatro amador, de uma concepção moderna do espetáculo. Agora, o teatro era visto como arte coletiva, resultado de muito estudo e preparo, composto por atores munidos de técnica e método, por uma equipe responsável pelos ajustes de iluminação e som, bem como o planejamento e preparação da cenografia; todos orquestrados pela figura do diretor.

Para preencher este papel, a veterana atriz Itália Fausta, que já havia colaborado anteriormente na elaboração e aconselhamento do Teatro de Brinquedo, foi escolhida devido ao seu profundo conhecimento da arte teatral:

Itália Fausta deu ao espetáculo e aos jovens do TEB os ensinamentos certos. Uma disciplina invejável. Uma concepção moderna de entrosamento da arte teatral, com bailado, música, luzes ${ }^{133}$.

Além das inovações na composição do espetáculo, a representação dos atores também passou a ter nova abordagem. $\mathrm{O}$ ator era responsável agora pelo total entendimento de seu personagem, o que demandava um estudo mais profundo e detalhado. Essa nova abordagem pode ser apreendida nas palavras de Sonia Oiticica, sobre sua preparação para interpretar a personagem Julieta:

Aqueles meses de ensaios, de trabalho intenso entre os estudos e aquela Julieta que se entranhava em mim a cada dia, quase como uma obsessão, a colaboração desinteressada entre os jovens atores, a nossa 'garra' mesmo, marcaram definitivamente o meu destino ${ }^{134}$.

Assim, depois de meses de ensaios, estreava a 28 de outubro de 1938, no Teatro João Caetano, o espetáculo Romeu e Julieta, que impressionou a todos com as renovações propostas. A expectativa era tanta, que mesmo antes da estréia, uma crítica atenta já

\footnotetext{
${ }^{133}$ POLÔNIO, Sandro. "Teatro de Estudante". Dionysos. Rio de Janeiro: SNT, n. 23, 1978. p. 69.
}

${ }^{134}$ OITICICA, Sonia. "Teatro de Estudante”. Dionysos. Rio de Janeiro: SNT, n. 23, 1978. p. 67. 
apontava a qualidade do trabalho daqueles estudantes. Depois do espetáculo, críticas de Mário Nunes, Álvaro Armando e César Brito circularam na imprensa destacando o valor artístico da produção, apontando a direção Magno-Fausta como fator determinante do sucesso.

Um outro importante crítico que se deteve alguns instantes na avaliação da performance do grupo de estudantes amadores foi Raimundo Magalhães Júnior, responsável pela coluna Teatro da revista Cultura Política. Apesar de considerar Romeu e Julieta uma cópia servil do filme que há pouco havia sido apresentado nos cinemas, o crítico aponta as novas peças do grupo, dirigidas posteriormente por Maria Jacinta, como promissoras. Para ele,

O Teatro do Estudante é uma das realizações mais sérias e mais dignas de estímulo no meio artístico brasileiro. O critério com que são organizados os seus espetáculos, o nível das peças escolhidas, o entusiasmo de seus jovens artistas, as revelações de talentos novos que proporciona, tudo isso são valiosas contribuições, que é mister reconhecer (27.3.2.2).

Um ano mais tarde, o grupo estréia Leonor de Mendonça, de Gonçalves Dias, no palco do Teatro Municipal. Brício de Abreu - assinando como Ludo - aponta sua surpresa em relação à apresentação dos estudantes. Para o autor, o cenário de Osvaldo Sampaio, a marcação de Éster Leão e a atuação de Sonia Oiticica destacaram-se no espetáculo (24.3.5.7).

É importante destacar que, apesar de ser citado em diversas notas e artigos, o Teatro do Estudante não foi tema de nenhum estudo mais longo e detalhado no material levantado em nossa pesquisa. Entretanto, é possível afirmar que suas realizações abriram caminho para a consolidação final do processo de afirmação da cena moderna brasileira, como veremos a seguir.

\section{Os Comediantes}

Na parte final dessa trajetória de afirmação da cena moderna brasileira encontram-se as realizações do grupo, também amador, Os Comediantes, que surge logo após o Teatro do Estudante e figura como destaque principal nos últimos anos de nossa pesquisa. Conforme 
apresentado anteriormente, nossa pesquisa nas fontes primárias se delimitou entre os anos de 1922 e 1942, tendo como ponto de partida a Semana de Arte Moderna e como marco final a encenação de Vestido de Noiva em 1943. Apesar de, teoricamente, nossa pesquisa se encerrar em 1942, decidimos ir um pouco mais além na tentativa de colher algum material relevante acerca da estréia da peça convencionada como marco inicial do teatro brasileiro moderno.

Sob o comando de Santa de Rosa e de Brutos Pereira, após a saída de Jorge de Castro, o grupo Os Comediantes, formado por Agostinho Olavo, Celso Kelly, Carlos Perry, Luíza Barreto Leite, Gustavo Dória entre outros, preparava-se a todo o vapor para a estréia de seu repertório. Partindo de uma interpretação brasileira do movimento de Jacques Copeau, iniciada pelo Teatro de Brinquedo, o grupo se dispunha a dar continuidade aos esforços de Álvaro e Eugênia Moreyra em renovar a estética do espetáculo nacional. Sua estréia em janeiro de 1940, com a representação da peça A Verdade de Cada Um, de Luigi Pirandello, gerou diversas críticas entre os intelectuais da época que visualizaram no grupo traços da renovação.

Guilherme de Figueiredo, em sua coluna na Revista do Brasil de dezembro de 1941, a propósito de uma re-encenação da peça de estréia d'Os Comediantes, aponta a importância do texto dramático escolhido e do amadorismo do grupo(16.3.3.7):

Teatro cerebral, elogio da dúvida, em que o enredo apenas serve para sustentar as premissas de um silogismo de muitas conclusões, ele dificilmente seria trazido às nossas casas de espetáculos, onde se vai apenas para ver 'um' ator, ou 'uma' atriz perfeitamente aplicados no trabalho de serem mais inteligentes e espirituosos do que os demais membros das companhias. Penso mesmo que o nosso teatro esteja perdendo a noção de personagem, uma vez que os chefes de companhias escolhem peças em que possam entrar eles próprios, com os seus próprios feitios físicos e morais. Acostumamo-nos a ver o papel representado pelo ator. Exigimos uma historieta e um desenlace feliz, tão feliz que consinta o sorvete e o chá depois do espetáculo. Pirandello não entra nas cogitações dos nossos profissionais.

Percebemos que ainda no início na década de 40 a estrutura das companhias teatrais baseava-se nos moldes do antigo teatro, tendo o dono-empresário da companhia à frente e 
acima de todos na composição do espetáculo. Seu sucesso de bilheteria não seria colocado à prova; manter as mesmas representações de sempre ainda era a melhor garantia. Dessa forma, as experimentações ficaram a cargo dos grupos amadores, que se arriscaram tanto na escolha do texto dramático quanto na inclusão de novos recursos em cena, como a cenografia proposta por Belá Paes Leme para esse espetáculo, como aponta Guilherme de Figueiredo (16.3.3.7):

A surpresa da noite foi a estréia da pintora e desenhista Belá Paes Leme como decoradora. Os seus cenários, modernos e sóbrios, longe de roubar a época da ação, deram-lhe um caráter estranho, de uma irrealidade magnífica, perfeitamente teatral. (...) Surpreendente tom de fantasia, que ao mesmo tempo fixa o lugar e o universaliza.

Raimundo Magalhães Jr, em sua coluna da revista Cultura Política, também destaca a composição da cenografia de Bela Paes Leme (27.3.2.9):

Seu cenário inicial foi o que, em linguagem popular os norte-americanos chamam de 'soco no olho' do público. Foi uma agressão ao sentido visual dos espectadores, que, cansados de ver coisas medíocres, se encontraram em face de uma cena de tão alta originalidade de tão moderno e fantasista estilo - receberam um choque agradável e impressivo. Toda gente pensou que não era possível fazer melhor. No entanto, o cenário seguinte era uma superação. Melhor ainda do que o primeiro, e, como esse, profundamente identificado com o clima sugestivo de Pirandello. Belá Paes Leme tem uma compreensão admirável dos problemas cenográficos, do casamento dos móveis com a cena e com o guarda roupa, de modo a produzir uma 'unidade' indispensável, sem a qual não se consegue a adesão total dos espectadores à ficção dramática.

Os espetáculos realizados pelo grupo chamavam a atenção da crítica e de outros artistas. A esperança depositada no trabalho do grupo gerou um novo conflito na cena nacional, no qual a classe teatral de profissionais se colocava contra as empreitadas de amadores despreparados. De qualquer modo, a crítica teatral queria mais e antecipava as expectativas do novo espetáculo do grupo. 
Dispostos a uma iniciativa que buscasse a implementação de um teatro de qualidade no Brasil, o grupo Os Comediantes partiu em busca de um original de qualidade, mas que fosse de autoria nacional. Após algumas tentativas, o grupo chegou ao texto do iniciante Nelson Rodrigues.

Escolhida a peça, o próximo passo seria a união dos esforços dos componentes do grupo com as idéias renovadoras de Santa Rosa e Ziembinski - diretor polonês exilado da guerra. A dupla, além de apontar o papel do diretor como unificador do espetáculo, destacava também a importância de uma renovação mais ampla, que abordasse tanto as questões do figurino e do cenário, quanto da iluminação. Estes aspectos da encenação ficaram sob a responsabilidade de Santa Rosa, que muito contribuiu para a estruturação e modernização dos palcos nacionais. Para ele, a construção de um cenário que permitisse a criação de uma atmosfera perfeita para a representação de determinada peça era essencial para a realização dramática:

É preciso fixar bem que a Cenografia, ou melhor, a Cenotécnica, arte de compor plasticamente a cena, é um legítimo métier. Possui as suas leis, o seu cortejo de acessórios, a sua preparação intelectual, a sua organização de elementos e o seu trato no fazer, que caracterizam um ofício ${ }^{135}$.

Dessa forma, o cenário devia complementar o espetáculo e não apenas ornamentá-lo. As linhas, cores e formas, estabelecidas ou apenas sugeridas no palco, serviriam para dar um toque de poesia à ação dos personagens. A consagração de Santa Rosa deu-se com a elaboração do cenário para a peça Vestido de Noiva, considerada, por diversos estudiosos do assunto, o marco inicial do teatro brasileiro moderno. Para melhor compreendermos a complexidade da inovação, recorreremos às palavras de Décio de Almeida Prado, que soube detalhar a exata articulação entre cenário e encenação:

... uma estrutura complexa, dividida em três planos, que resolvia com perfeição todos os intricados problemas relativos aos locais onde a ação imaginariamente decorre. Mas

\footnotetext{
135 SANTA ROSA, Tomás. "Para um Teatro Teatral”. In: BARSANTE, Cássio Emmanuel. Santa Rosa em Cena. Rio de Janeiro: Instituto Nacional de Artes Cênicas, 1982. p. 118.
} 
dessa realidade material, representada pela multiplicidade de locais cênicos, passava imediatamente para a irrealidade do desempenho: gestos, inflexões, movimentos, tudo chegava de longe, esmaecido ou distorcido, como que entrevisto através de um véu, de um sonho. [...] O próprio delírio recebia uma face, tornava-se visível, de acordo com a estética do expressionismo ${ }^{136}$.

A concretização desses efeitos em cena só se tornou possível com a aplicação das idéias de Ziembinski, que somara seus conhecimentos ao grupo Os Comediantes e entrara na luta pela conquista de um teatro de qualidade. Sua formação expressionista e seu vasto conhecimento dos componentes do espetáculo permitiram que as concepções do moderno teatro europeu finalmente se consolidassem entre nós. Na função de coordenador do espetáculo - diretor - Ziembinski fez de Vestido de Noiva a revolução modernista há tanto esperada.

Além de exigir dos atores um estudo profundo do texto para desvendar a real intenção de cada fala, realizava incessantes ensaios para obter a iluminação exata do espetáculo, que trazia 174 mudanças de luzes. E esta foi, sem dúvida alguma, a grande contribuição do polonês, transferindo as gambiarras e as luzes da ribalta por uma iluminação significativa:

Em 1943, o nosso teatro não era iluminado artisticamente. Pendurava-se, no palco, uma lâmpada de sala de visitas, ou de jantar. Só. E a luz fixa, imutável e burríssima, nada tinha a ver com os textos e os sonhos da carne e da alma. Ziembinski era o primeiro, entre nós, a iluminar poética e dramaticamente uma peça" ${ }^{137}$.

Convém destacar que o sucesso atingido foi resultado de vários ensaios clamados pelo incansável diretor. Mesmo na véspera da estréia, o extremo cansaço dos atores não amolecia Ziembinski, que buscava a mais perfeita iluminação. "Com efeito, a exaustão enfurecia e desumanizava as pessoas. Ninguém tinha mais noção da própria identidade. Os artistas passaram a detestar uns aos outros"

\footnotetext{
${ }^{136}$ PRADO, Décio de Almeida. Op. cit. 2002, p. 75.

${ }^{137}$ RODRIGUES, Nelson. "Os Comediantes". Dionysos. Rio de Janeiro: SNT, n. 22, 1975. p. 75 . p. 51.

${ }^{138}$ Idem, p. 52.
} 
É curioso observar que a estréia da peça Vestido de Noiva não gerou, de imediato, frutos nas críticas teatrais de 1943 e nem mesmo de $1944^{139}$. Nossa intenção, ao avançarmos a data limite de nossa pesquisa, era encontrar as repercussões e considerações dos críticos acerca do espetáculo, o que não ocorreu.

De qualquer modo, por conta de todas as renovações propostas e colocadas em prática pelo grupo na peça de Nelson Rodrigues, convencionou-se, algum tempo depois, considerar a encenação de Vestido de Noiva o marco inicial do moderno teatro brasileiro. Sabemos que o processo de afirmação do conceito moderno ainda levou mais alguns anos para se consolidar em definitivo nos palcos nacionais. A formulação sistemática do moderno, sua difusão plena e inconteste no mercado fica sob a responsabilidade do Teatro Brasileiro de Comédia, o TBC de São Paulo ao longo da década de $50^{140}$.

Assim, encerra-se um longo processo de afirmação da cena moderna nacional. Iniciase agora a hegemonia do diretor. Muito longe de ser uma lacuna na história do teatro brasileiro, as décadas de 20 e 30 apresentaram iniciativas com intenções e, pelo menos, alguns aspectos modernos. Vemos o período como um acúmulo de experimentações e criações que foram somando idéias e transformações na composição cênica, na organização da companhia, na existência de um diretor, na preocupação com o figurino e a iluminação, na visão do teatro como arte coletiva, no aprendizado com o teatro europeu, na maturidade de autores nacionais e na consolidação de uma crítica especializada. Todas essas etapas permitiram a convergência do projeto estético com o ideológico, traduzida na concretização do moderno teatro brasileiro.

\subsection{Os Intelectuais e o Serviço Nacional de Teatro: Um Parêntesis Final}

Buscamos, ao longo deste trabalho, considerar a posição dos grupos de intelectuais em relação às produções artísticas da época, destacando suas visões e anseios e sua interligação com a sociedade e com o mercado. Reservamos para este parêntesis final as considerações sobre um período determinante na história do teatro brasileiro e nas

\footnotetext{
${ }^{139}$ Vale apontar que estamos nos referindo às revistas por nós pesquisadas e não ao conjunto de críticas encontradas em todos os jornais e revistas da época.

${ }^{140}$ BRANDÃO, Tania. Op. cit. p. 29.
} 
produções artísticas realizadas a partir de 1937 - ano de implementação do regime do Estado Novo. Pretendemos apontar de que modo a relação governo e classe teatral se estabeleceu e quais foram os seus resultados tanto na cena nacional quanto na repercussão junto à imprensa periódica consultada.

Foi apenas no período do Estado Novo que mecanismos oficiais foram estabelecidos para o controle das atividades culturais do país. Além do comando das atividades políticas e econômicas, o governo passou a ter também o controle das diversas formas de produção ideológica. Como já foi dito na primeira parte deste trabalho, o DIP (Departamento de Imprensa e Propaganda) passou a cuidar a imagem do governo e a manter a harmonia ideológica entre os veículos de comunicação.

Essas alterações provocaram uma mudança considerável no posicionamento do intelectual frente ao poder do Estado:

Grande parte da intelectualidade brasileira, a partir do governo Vargas, passa a manter com os órgãos públicos relações especiais de dependência e favor. (...) A extensa rede formada pelos órgãos especializados na promoção e controle das atividades culturais era reforçada pela participação de intelectuais de prestígio na máquina administrativa com a qual o Estado empreende a burocratização da cultura ${ }^{141}$.

Com a criação do S.N.T. (Serviço Nacional do Teatro) pelo decreto-lei $\mathrm{n}^{\circ} 29$, promulgado em 21 de dezembro de 1937, o Estado passa a promover a formação profissional dos atores teatrais e a conceder subvenções para as companhias. Estabelece-se nesse período uma nova relação entre o intelectual e o artista e a sociedade e o Estado; as forças que sustentavam essas ligações estavam pautadas na oposição ‘apoio' e ‘coerção'. Da mesma forma que o Estado aprovava financiamentos a companhias e promovia o desenvolvimento da cultura, vigiava e descartava aquilo que não estivesse dentro dos padrões da moral e da ordem pública. O Governo passa a ocupar o lugar de destaque no projeto ideológico do teatro nacional, que assume agora novas estratégias de produção.

Mesmo antes de assumir o poder, Getúlio Vargas ganha da classe teatral apoio de admiração ao propor um projeto - ainda como deputado e crítico teatral do jornal Debate,

${ }^{141}$ Idem, p. 40. 
de Porto Alegre - que defendia a aceitação da profissão de artista teatral. Este projeto tornou-se a Lei Getúlio Vargas em 16 de julho de 1928.

Em janeiro de 1937, o ministro Gustavo Capanema estabelece a Comissão do Teatro Nacional, subsidiando companhias oficiais para montagem de espetáculos e excursões pelo país. Esta Comissão foi estabelecida depois da polêmica causada pelo incentivo dado ao Teatro-Escola de Renato Vianna. Acusado pela classe teatral de falta de critérios claros, Capanema apresenta a proposta de uma comissão, que servisse como um mecanismo de avaliação das decisões do governo. Entre os membros do C.T.N. estavam Múcio Leão, Oduvaldo Vianna, Francisco Mignone, Sergio Buarque de Holanda, Olavo de Barros, Benjamin Lima e Celso Kely ${ }^{142}$.

Sob o pseudônimo "Ludo", Brício de Abreu destaca em um de seus artigos publicados no periódico Dom Casmurro a decisão do ministro em dar a Jaime Costa e Álvaro Moreyra um auxílio de 600 contos para a organização de novas companhias que se responsabilizassem pelo "levantamento moral" do nosso teatro. Esse auxílio permitiu que a Companhia Jaime Costa e a Companhia Dramática Álvaro Moreyra fizessem parte da temporada oficial de teatro - a primeira teve sua estréia em maio de 1937 no Teatro Rival e a segunda, teve a oportunidade de excursionar por São Paulo e Porto Alegre (24.3.2.1).

O apoio da classe teatral ao governo aumenta ainda mais com a criação do S.N.T., despertando em todos uma esperança de melhoria das condições de trabalho e oportunidade de modernização.

Esse sentimento pode ser constatado por meio de diversas manifestações de importantes nomes do setor. Brício de Abreu, em Dom Casmurro (24.3.5.5), elogia o subsídio dado pelo governo Getúlio Vargas, colocando à frente do S.N.T. "o talentoso Abadie Faria Rosa".

Embora o regime Vargas tenha implantado pela primeira vez no país mecanismos administrativos que visavam regulamentar a atuação do governo junto ao teatro, esta sempre foi marcada pelo personalismo, a ponto de contar com a intervenção direta do

\footnotetext{
142 PEREIRA, Victor Hugo Adler. "Os Intelectuais, o Mercado e o Estado na Modernização do Teatro Brasileiro". In: BOMENY, Helena (org). Constelação Capanema: Intelectuais e Políticas. Rio de Janeiro: Fundação Getúlio Vargas, 2001. p. 65.
} 
presidente nas decisões sobre o setor, e dependia diretamente de laços de simpatia e amizade junto aos círculos do poder ${ }^{143}$.

$\mathrm{O}$ personalismo e o privilégio dado àqueles que tinham algum tipo de relacionamento com o poder vem à cena nas diversas críticas publicadas a partir de 1939 , quando o S.N.T. não mais inspirava esperança e crédito entre o meio teatral. A direção do órgão do governo foi questionada por uma série de motivos. No periódico Dom Casmurro podemos acompanhar alguns dos pontos pelos quais Abadie Faria Rosa foi atacado: a) por não incluir a Companhia Dramática Brasileira no programa de subsidiados definido por Capanema; b) por não estar presente na estréia da Companhia Delorges Caminha no Teatro Carlos Gomes em abril de 1940; c) por impor suas peças às companhias subvencionadas; d) por apresentar vantagens apenas aos empresários e aos donos de casas teatrais; entre outros.

Percebemos por meio dos artigos encontrados nas revistas Dom Casmurro, Anuário Brasileiro de Literatura e Cultura Política que todas as criticas estavam sempre direcionadas ao diretor do S.N.T., Abadie Faria Rosa. As figuras do ministro Capanema e do presidente Getúlio Vargas eram poupadas e muitas vezes elogiadas; eles eram os detentores das boas idéias que eram desvirtuadas por Abadie. Podemos encarar esse fato como uma estratégia de comunicação para se tratar de uma questão tão ruidosa: colocar o diretor do S.N.T. como bode expiatório das desavenças entre a classe teatral e o governo 144 .

Em um dos órgãos de propaganda do governo, a revista Cultura Política, podemos observar o cuidado dos intelectuais responsáveis em proteger a imagem do governo. Em um texto de Ruben Gil, intitulado Teatro (27.3.2.12), as causas da decadência do teatro nacional são atribuídas ao regime que antecedeu o Estado Novo:

O morbus de que definhou a arte do palco entre nós, é de origem espiritual, não de ordem material. (...) A produção autoral é que foi votada à invalidez, induzida a enfermar quando em 1895 procurou subsistir, e recorreu a paliativos ineptos. Foi o caso

\footnotetext{
${ }^{143}$ Idem, p. 63.

${ }^{144}$ Idem, p. 74.
} 
de abandonarem os teatrólogos a missão fundamental do teatro para se empregarem na confecção de espetáculos puramente, ou melhor, impuramente recreativos.

E ainda destaca a função reparadora do novo Governo:

Instalando a Divisão de Teatro e Cinema do Departamento de Imprensa e Propaganda, e atribuindo a função controladora - melhor dizendo, orientadora - do teatro a autoridades não policiais, o Estado Nacional Brasileiro adotou medida sem dúvida proximamente reparadora do erro psicológico do Regime precedente. E o teatro virá a mobilizar inteligências mais preocupadas com a sua transcendência de ramo de belas artes, mais empolgadas pelo seu desígnio de realização cultural.

Assim, as discordâncias entre a classe teatral e o S.N.T. eram sempre direcionadas a um diretor ou responsável, mas nunca encaminhada aos homens do governo. Um outro ponto de conflito foi a liberação de verbas para grupos de amadores, como $O s$ Comediantes. Grande parte da classe teatral não aceitava o fato do governo estar preocupado em angariar fundos para financiar montagens de uma produção distanciada do gosto e do entendimento intelectual do público. De modo a abafar as divergências, a tendência na administração Capanema era "de privilegiar, com a concessão de auxílios, pedidos e sugestões advindas de grupos de intelectuais consagrados tradicionalmente ou na leva dos modernistas que integravam ou gravitavam em torno do Ministério da Educação e Saúde" ${ }^{\Perp 145}$.

A nova estratégia baseava-se em solidificar amizades, estender favores e ampliar as afinidades com a burguesia de modo a garantir o apoio constante do Governo. O mesmo poder que vetou a representação de O Homem e o Cavalo, de Oswald de Andrade no final da década de 30, permitiu e, até mesmo, subsidiou, a montagem de Vestido de Noiva, de Nelson Rodrigues no início de 40. A liberação e a repercussão da peça também foram frutos de uma manobra antecipada do diretor do espetáculo:

A afinidade de situação de classe entre os participantes do grupo e a platéia para quem realizavam habitualmente seus espetáculos foi inegavelmente uma das garantias de

${ }^{145}$ Idem, p. 76. 
repercussão de suas realizações. [...] Ziembinski estava atento a esse fato, e escolheu, para a estréia de Vestido de Noiva, atores que eram previamente reconhecidos como figuras destacadas da alta sociedade. Misturavam-se as afinidades com a burguesia às ligações com uma parcela influente da intelectualidade, o que propiciava contarem com o apoio junto a instâncias decisórias de financiamento e legitimação da cultura na administração pública. A simpatia imediata que despertaram em alguns intelectuais de renome justifica-se, além dessas ligações pessoais, pelo fato de efetivamente procurarem atender às expectativas dos que esperavam ver surgir o 'moderno teatro brasileiro, $^{146}$.

Passada a fase de encantamento com o Serviço Nacional de Teatro, questionamentos sobre sua eficácia passam a ocupar as páginas das revistas dos periódicos consultados. Entre eles, há uma série de entrevistas, em forma de enquete, publicadas na revista Fon Fon, assinadas por Haroldo Sumner Negrão. Os seis entrevistados são: a) o próprio diretor do S.N.T., Abadie Faria Rosa (13.4.1); b) Ruben Gill, revistógrafo consagrado e colaborador da revista Cultura Política (13.4.2); c) Héber Boscoli, diretor do programa Que é que o teatro tem?, da Rádio Nacional e funcionário do DIP (13.4.3); d) Anselmo Domingos, autor teatral e diretor do programa Teatro por dentro, da Rádio Cruzeiro do Sul (13.4.4); e) Grande Otelo, ator cômico da Rádio Mayrink Veiga (13.4.5); f) Henrique Pongetti, destaque no mundo do teatro, cinema, imprensa e letras (13.4.6). Suas respostas à pergunta "O Serviço Nacional de Teatro tem alcançado a finalidade do decreto que o criou?" foram respectivamente:

Pelo menos está alcançando. A obra de Teatro não se faz com leis e sim com cultura. Nada mais óbvio. Entretanto, é de convir que o ambiente do nosso Teatro tem melhorado. Este ano, chegamos a ter nada menos de dez teatros funcionando aqui no Rio e viajaram pelo país nada menos de doze companhias nacionais. Ora, tudo isso demonstra um melhor interesse pelo Teatro e patenteia, pela melhora que se tem alcançado de ano para ano, que o problema do Teatro Nacional, há cem anos tentado no país, é uma questão de tempo, de adiantamento, de grau de civilização. Sendo assim, sob determinado aspecto, o SNT está alcançando a finalidade do decreto que o criou (Abadie Faria Rosa).

\footnotetext{
${ }^{146}$ PEREIRA, Victor Hugo Adler. Op. cit. p. 70.
} 
Cabalmente. Mal grado toda a ginástica mental de alguns dos negadores de sua eficiência, o SNT vem objetivando sua finalidade. Para desequilíbrio e estatelamento de qualquer perfídia arquitetada em desprimor do Serviço Nacional de Teatro, basta referir o verdadeiro esplendor alcançado pelo teatro nacional presentemente. Porque a verdade é esta: ao menos há vinte anos, não se registrava uma expansão, aproximada que fosse, da hoje desfrutada pelas empresas, os artistas, os autores e todos os interessados nas atividades de cena. Promovendo excursões dos elencos a todos os pontos do país, resolvendo o problema da locomoção das companhias, o SNT incentivou a arte e as letras teatrais, e assegurou o trabalho e o pão aos profissionais do teatro. Outros detalhes de sua eficiência deixam de ser discutíveis, em face da realidade iniludível do resultado auspicioso da medida citada (Ruben Gill).

Este é um dos pontos delicados desta 'enquete': se eu analisar a pergunta, friamente, deixando de lado a amizade, a simpatia e o respeito que o seu diretor, dr. Abadie Faria Rosa, merece, teria certamente de apontar inúmeros senões na atividade do SNT! Mas... Quem sou eu para ditar leis? ... O futuro a Deus pertence. A esperança da família teatral está toda ela depositada no valor ditado: "Depois da tempestade vem a bonança...". Aguardemos...(Hérber de Bôscoli).

Um artigo de página interia não daria para o assunto. Prefiro responder com uma pergunta: por que o sr. Abadie faria Rosa não solicita do governo a isenção dos pesados impostos que tanto sufocam o nosso teatro? E depois, quando tivesse tempo, bem que poderia fazer uma campanha pró-construção de uns dois ou três teatros na cidade, e um ao menos num subúrbio adiantado. Talvez que o decreto não tenha criado o Serviço Nacional de Teatro para isso. Mas se o sr. Abadie conseguisse essas coisas, que bom! Mereceria um busto, ali em frente ao "Amarelinho" (Anselmo Domingos).

Não. Até agora, ainda não apresentou, amparado por ele, um elenco, um ator, ou uma atriz dos outros estados do Brasil... Ora, esse Serviço diz-se Nacional: portanto não pode ser... carioca! Isso de premiar os que aqui estão só tem o efeito de provocar dissidências e ódios... Absolutamente não ataco (quem sou eu?) o exmo.sr.dr. Abadie Faria Rosa. Apenas, dentro de um direito que me assiste, externo uma opinião. Alguém disse que o diretor do SNT possui documentação para desmascarar e retratar uma 
porção de Tartufos. Ora, o SNT não é nenhum atelier fotográfico nem há motivo para arquivar os 'nomes feitos' de quem quer que seja... É preciso que o sentimentalismo não tolha nenhum dos setores do Brasil Novo. Quais são os Tartufos? (Grande Otelo).

O Serviço não conseguiu aumentar o número de teatros do Rio nem modificou a mentalidade dos nossos palcos. Suas pretensões são modestas: dar de comer a quem tem fome e de vestir aos nus (Henrique Pongetti).

Podemos observar que as opiniões são diversas. Aqueles que de alguma forma estão relacionados ao poder defendem o órgão e apontam as melhorias dos nossos palcos, na tentativa de convencer o leitor da eficácia das decisões do S.N.T. Entretanto, há aqueles como Hérber de Bôscoli, que pouco falam para não comprometer sua amizade com Faria Rosa, demonstrando que as relações pessoais precisavam ser preservadas. Já Anselmo Domingos, Grande Otelo e Henrique Pongetti destacam as falhas do S.N.T., como a cobrança de altos impostos e o foco em excesso nos palcos do Rio de Janeiro.

Foi apenas em 1945, com a morte de Abadie Faria Rosa, que João Massot, cunhado do ministro Capanema, assume integralmente a direção do Serviço Nacional de Teatro. O término da gestão de Abadie Faria Rosa coincide com o desfecho do Estado Novo. A abertura política que estava por vir e a descentralização do poder do Ministro Capanema anunciavam novos tempos e caminhos para o país e para o teatro nacional. De qualquer forma, esses quase dez anos de Estado Novo foram determinantes para que o teatro nacional trilhasse seu caminho rumo à modernidade. Com novas estratégias e formas de organização, e com o incentivo e subsídio dado pelo Governo, a classe teatral apresentou mecanismos e propostas que, mesmo direta ou indiretamente, levaram à afirmação da cena moderna nacional. 


\section{Considerações Finais}

Queremos crer que a pesquisa em fontes primárias e a classificação sistemática do material encontrado resultaram em duas contribuições para o estudo do teatro brasileiro: primeiro, um relevante corpus documental que abrange boa parte do que foi publicado sobre o nosso teatro nas revistas das décadas de 20 e 30; e segundo, a recuperação de parte significativa de informações a respeito da história do teatro nacional, nos vinte e poucos anos anteriores à representação da peça Vestido de Noiva.

O corpus nos permitiu observar que o teatro brasileiro era abordado e discutido dentro de instâncias diversas, que se agrupavam pela semelhança da natureza de cada matéria e pelos ideários daqueles que compunham os periódicos em questão. A análise resultante da pesquisa nos possibilitou confirmar a importância do periodismo "como instância de representação e legitimação de indivíduos, grupos e idéias, espaço celebrativo de aspirações e projetos de gerações" ${ }^{147}$, que possui sua importância documental da história devido à preferência do leitor por textos curtos, à eficácia na divulgação de vanguarda e à disseminação do gênero no mercado.

Iniciamos a pesquisa em busca de material que pudesse complementar os estudos já existentes, de modo a ampliar o conhecimento desse período histórico e a facilitar futuras pesquisas sobre o assunto. Desde o ponto de partida, estávamos cientes de que não esgotaríamos todas as publicações e de que não consideraríamos outros veículos de comunicação que também compõem o registro da vida artística e cultural da época. Nosso propósito era o de apresentar um recorte da vida teatral através das matérias encontradas nas revistas e desenvolver um estudo que sistematizasse essas informações.

Essa viagem pelos periódicos do período modernista nos revelou uma intensa e agitada vida teatral nas décadas de 20 e 30 que nos levou a caminhos já planejados e outros, inesperados. O periodismo pesquisado abrangia todos os tipos de ocorrência, desde pequenas notas e fotos sobre os artistas, até críticas de peças e discussões sobre os rumos do teatro nacional, o que nos permite afirmar que as revistas ocuparam um importante

\footnotetext{
${ }^{147}$ MARTINS, Ana Luisa. Op. Cit. p. 557.
} 
espaço de circulação de idéias e tinham, como função, a divulgação das produções da época e a disseminação de debates sobre os caminhos do teatro mundial e nacional.

O recorte feito através das fontes primárias nos proporcionou uma visão mais abrangente da vida teatral da época e trouxe à tona realizações e contribuições obscurecidas pela passagem do tempo: como o primeiro quadro da peça Idéias Novas, de Graciliano Ramos, publicada nas páginas da Revista do Brasil (16.1.1), os editais e pareceres dos concursos de peças teatrais realizados pela Revista da Academia Brasileira de Letras, o elevado número de peças publicadas em Leitura para Todos, as realizações do teatro moderno estrangeiro em Movimento Brasileiro e o acompanhamento mensal das realizações do rádio-teatro pelos críticos da revista Fon Fon.

É uma pena não termos conseguido localizar a continuação da peça Idéias Novas, de Graciliano Ramos, que nos chamou a atenção por se tratar de uma comédia. O primeiro quadro - estruturado em torno da relação entre o Capitão Lobo, sua esposa D. Aurora e sua filha Mariana - ironiza o progresso, as relações políticas e a organização familiar. Abaixo reproduzimos um breve trecho de uma conversa entre Mariana e sua amiga Adelaide:

Adelaide - Um horror, minha filha, um horror. Nunca vi tanta miséria. Eu lhe conto porque sou sua amiga. Um horror. Sabe o que andam espalhando por aí, na farmácia, no bilhar, na porta da igreja?

Mariana - Não. Você ainda não se manifestou.

Adelaide - Posso falar?

Mariana - Pode, pode. Fale à vontade.

Adelaide - Pois sim, meu coração. Juram que você não é mais moça.

Mariana - Diabo! Com dezoito anos? São bem exigentes.

Adelaide - Não zombe, meu anjo. Você comprometeu-se namorando três rapazes ao mesmo tempo.

Mariana - Ao mesmo tempo não.

Adelaide - Os três num dia. Vivem brigando por sua causa, e essa gente desocupada julga que você fez tudo com eles.

$[\ldots]$

Adelaide - Felizmente só foram três, não é? (Suspira) Você se inutilizou, meu bem. Aqui não arranja casamento.

Mariana - E quem lhe disse que pretendo casar-me e ficar aqui mofando? 
Adelaide - Não pretende?

Mariana - Ah! Não. No ano vindouro findo o meu curso e bato as asas. Arrumo aí um emprego qualquer e depois uma comissão no Rio. Este negócio está apalavrado. Lá faço concurso e engancho-me num ministério. É certo. Se em seis meses não conseguir o que desejo, é porque só sirvo para ser professora em Sant'Ana do Ipanema.

Adelaide - Professora com a reputação estragada, Mariana. Uma professora que namora três homens num dia.

Mariana - Bobagem. Os três não valem um homem. Mas não há receio. Atracome no Sul e viro carioca.

$\mathrm{O}$ autor Graciliano Ramos nos surpreende com o tom cômico dado à peça. Pesquisamos diversos trabalhos sobre o autor, sobre suas obras, sobre a Revista do Brasil e sobre a revista Cultura Política, na qual o autor era responsável pela seção "Quadros e Costumes do Nordeste", em busca de pistas que nos levassem aos outros atos de Idéias Novas. Entretanto, não foi possível localizar a continuação da peça.

Uma outra importante contribuição de nossa pesquisa foi o levantamento e o registro de uma série de fotos de artistas e intelectuais da época, como Leopoldo Froes, Procópio Ferreira, Jaime Costa, Sarah Bernhardt, bem como de cenas de peças como A Juriti, de Viriato Correia, Longe dos Olhos..., de Abadie Faria Rosa, Senhora Futilidade, de Paulo de Magalhães, A Escola da Mentira, de Cláudio de Souza, O Modesto Filomeno, de Gastão Tojeiro, entre outras. As revistas Fon Fon, Leitura para Todos, Ilustração Brasileira e Dom Casmurro possuem um significante acervo de fotos e ilustrações que muito contribuiu para nossa pesquisa e que deve ser valorizado como um importante registro da história do teatro brasileiro.

A natureza e a quantidade dos artigos encontrados permitiram que agrupássemos o corpus em dois grupos bem definidos: o das revistas modernistas e o das outras revistas. $\mathrm{O}$ primeiro grupo vislumbrava o advento do cinema como causa da morte irremediável da arte teatral. A atenção dispensada a então considerada arte representativa do século XX resultou na baixa ou quase nula contribuição dos periódicos modernistas à nossa recuperação de fatos sobre o teatro nacional. O segundo, sem propósitos de vanguarda, define-se como o 
responsável pela maior parte da publicação encontrada e como um importante registro da composição e organização da vida teatral da época.

A partir desse registro, pudemos apresentar os principais dramaturgos, atores e companhias em destaque e de que modo a tríade ator, texto e público se organizava nas primeiras décadas do século XX. Esse levantamento da configuração da vida teatral da época resultou na recuperação de boa parte do repertório de sucesso tanto dos dramaturgos quantos dos principais atores, bem como na discussão entre os que apoiavam e os que criticavam esse tipo de teatro. Foi possível visualizar, por meio das matérias, um processo de amadurecimento da mentalidade crítica e artística que passava a exigir mais de uma produção esgotada e fechada dentro de suas inalteradas convenções. A passagem para a década de 40 apontou mudanças na concepção da arte do ator e das produções dramatúrgicas, que permitiram uma nova demanda para uma nova estrutura teatral.

O cinema - arte nova e ainda desconhecida - passa a ser encarado como grande ameaça. Para muitos, a arte teatral estaria vivendo seus últimos suspiros e sucumbiria face à grandiosidade e ao alcance da grande tela, que começa a ser considerada como principal forma de entretenimento em grande escala e, por isso, ganha espaço no mercado industrial e na imprensa especializada. Entre as principais contribuições de nossa pesquisa relacionadas ao advento do cinema estão: os textos de Gastão Tojeiro, Eduardo Victorino, Raimundo Magalhães Júnior e Álvaro Moreyra; o conjunto de artigos de Antônio de Alcântara Machado publicado na revista Terra Roxa e Outras e Terras e na Revista do Brasil; e as enquetes promovidas por Fon Fon e Dom Casmurro sobre a ameaça do cinema à arte teatral.

A modernidade do cinema gerou uma constante discussão nas páginas das revistas pesquisadas, principalmente em relação à técnica, às condições de produção e ao alcance da arte teatral. Esse intenso debate possibilitou empréstimos e aperfeiçoamentos de técnicas que garantiram a renovação e sobrevivência do teatro nacional, que "aprendeu" a se beneficiar do advento da arte cinematográfica.

Já o rádio-teatro foi ganhando aos poucos posição de gênero autônomo e independente do tradicional teatro dos palcos. Procuramos apresentar seu processo de evolução e a importância dada a essa prática pelos artistas e intelectuais da época. Inserido no mercado como instrumento estratégico de comunicação com as massas e como gerador 
de lucros oriundos das agências de publicidade, o rádio se tornou um espaço atrativo para os artistas daquela geração, que desenvolveram convenções próprias e conquistaram seu espaço nas páginas da imprensa periódica, com seções cada vez maiores e, até mesmo, com revistas especializadas no assunto.

Entre as principais contribuições de nossa pesquisa para o estudo do rádio-teatro estão as notas e matérias localizadas nas páginas da revista Fon Fon. Tanto a seção "RádioTeatro" quanto "A Semana Rádio-Teatral” se destacaram na abordagem do tema, no debate sobre as convenções do novo gênero e no registro das principais peças irradiadas.

Por fim, a partir do material levantado reconstituímos o processo de afirmação da cena moderna brasileira, sempre cotejando com os estudos já existentes, de modo a analisar as contribuições e as iniciativas das décadas de 20 e 30, que possibilitaram e/ou resultaram na representação de Vestido de Noiva. Entendemos que esses anos de suposto vazio foram essenciais para a constituição de uma estrutura consciente e suficientemente autônoma para explorar o conceito de "teatro moderno". Cada tentativa, cada experimento era um passo dado à frente; em conjunto, esses passos possibilitaram o amadurecimento de um ideal e a convergência de elementos-chave para uma produção moderna: abria-se agora o caminho para o estabelecimento de uma nova dramaturgia, de uma diferente visão da arte do ator, de uma crítica séria e de orientação estética e do diretor como figura central do espetáculo.

A experimentação estética da década de 20 , com modificações diretamente ligadas à forma e à linguagem, e o projeto ideológico explorado ao longo da década de 30, com preocupações acerca da visão de mundo e do modo de agir sobre ele, culminaram na criação de uma consciência crítica e estética, apoiada na continuidade e no método, gerando um caráter construtivo da criação e da crítica modernistas.

Permeando todo esse processo estavam as ações de cunho governamental, operacionalizadas por mudanças político-econômicas e pela relação de poder estabelecida entre Estado e intelectuais. A oposição 'apoio' e 'coerção' pautava e sustentava o desenvolvimento da cultura e a manutenção da ordem pública. Com a criação do S.N.T. (Serviço Nacional de Teatro), são estabelecidas novas estratégias de produção do teatro nacional, subvencionado e fiscalizado pelo olhar da censura. Os periódicos Dom Casmurro e Cultura Política possibilitaram a ampliação do nosso olhar acerca das imposições do S.N.T. e contribuíram para o registro de matérias sobre o assunto. 
Esses foram os caminhos trilhados por nossa pesquisa. Do material coletado, ainda partem outros caminhos que merecem ser explorados com mais cuidado e que podem contribuir para a história do teatro brasileiro. Tentamos, nas temáticas por nós definidas, aprofundar ao máximo a análise, trazendo à tona fatos, exemplos e citações que sustentassem nossa visão. Acreditamos que as décadas de 20 e 30 guardam uma valiosa composição cênica, envolvendo processos, tentativas, ideais e discussões que muito contribuíram para o processo de afirmação da moderna cena nacional. 


\section{Bibliografia}

ABREU, Bricio. Esses Populares tão Desconhecidos. 1ed. Rio de Janeiro: E. Raposo Carneiro, 1963.

ANTELO, Raul. Literatura em Revista. São Paulo: Ática, 1984.

ANDRADE, Almir de. Cultura Política. Rio de Janeiro: n. 02, abril de 1941.

ANDRADE, Carlos Drummond de. Entrevista. Publicada na dissertação de KREINZ, Glória Aparecida Rodrigues. Revista Nova. São Paulo - 1979.

ANDRADE, Mário de. “O Inquérito da 'Revista do Brasil' acerca das 'Tendências Atuais da Literatura Brasileira"”. In: Revista do Brasil. n. 22, abr. 1940.

ANDRADE, Mário. "Movimento Modernista". In: Aspectos da Literatura Brasileira. $6^{\text {a }}$ ed. Belo Horizonte: Itatiaia, 2002.

ANTUNES, Delson. Fora do Sério: um Panorama do Teatro de Revista no Brasil. Rio de Janeiro: FUNARTE, 2004.

AVELLAR, José Carlos. "Cinema e Espectador", In: XAVIER, Ismail. O Cinema no Século. Rio de Janeiro: Imago, 1996.

BAHIA, Juarez. Jornal, História e Técnica-História da Imprensa Brasileira. 4ªed. São Paulo: Ática, 1990.

BENDER, Flora Christina. A Scena Muda. Tese de Doutorado. 4vol. São Paulo: FFLCH/USP, 1979.

BERTHOLD, Margot. História Mundial do Teatro. 2ed. São Paulo: Perspectiva, 2004.

BOAVENTURA, Maria Eugenia da Gama Alves. Movimento Brasileiro: Contribuição ao Estudo do Modernismo. Dissertação de Mestrado. São Paulo: FFLCH/USP, 1975.

BRAGA, Claudia. Em Busca da Brasilidade: Teatro Brasileiro na Primeira República. São Paulo: Perspectiva, 2003.

BRANDÃO, Tania. A Máquina de Repetir e a Fábrica de Estrelas: Teatro dos Sete. Rio de Janeiro: 7 Letras, 2002.

BRITO, Mário da Silva. O Alegre Combate de Klaxon. Introdução da edição fac-similada da revista Klaxon. São Paulo: Livraria Martins, 1972. 
BUMIRGH, Nádia Regina Marques Coelho. Graciliano Ramos e a Revista Cultura Política. Tese de Doutorado. São Paulo:FFLCH/USP, 2003.

CACCESE, Neusa Pinsard. Festa - Contribuição para o Estudo do Modernismo. São Paulo: IEB/USP, 1971.

CACCIAGliA, Mario. Pequena História do Teatro no Brasil. São Paulo: Editora da Universidade de São Paulo,

CAFEZEIRO, Edwaldo e GADELHA, Carmem. História do teatro brasileiro: de Anchieta a Nelson Rodrigues. Rio de Janeiro: Editora UFRJ/FUNARTE, 1996.

CAMPOS, Augusto de. "Revistas Re-vistas: os Antropófagos". Introdução da edição facsimilada da Revista de Antropofagia. São Paulo, 1976.

CANDIDO, Antonio. A Educação pela Noite e Outros Ensaios. São Paulo: Ática, 2000.

CAVAlCANTE, Maria Neuma Barreto. Clima - Contribuição para o Estudo do Modernismo. Dissertação de Mestrado. São Paulo: FFLCH/USP, 1978.

CARNEIRO, Maria Luiza Tucci e KOSSOY, Boris (Org.). A Imprensa Confiscada pelo DEOPS - 1924-1954. São Paulo: Ateliê Editorial; Imprensa Oficial do Estado de São Paulo; Arquivo do Estado: 2003.

(Org). Minorias Silenciadas: História da Censura no Brasil. São Paulo: EDUSP/ Imprensa Oficial do Estado/ FAPESP, 2002.

Livros Proibidos, Idéias Malditas. 2 ed. São Paulo: Ateliê Editorial/FAPESP, 2002.

CASTELLO, José Aderaldo. “A Pesquisa de Periódicos na Literatura Brasileira”.In: NAPOLI, Roselis Oliveira de. Lanterna Verde e o Modernismo. São Paulo: IEB/USP, 1970.

CHAVES, Eneida Maria. O Mundo Literário - Um Periódico da Década de 20 no Rio de Janeiro. 2 vol. Dissertação de Mestrado. São Paulo: FFLCH/USP, 1977.

CHIARADIA, Maria Filomena Vilela. A Companhia de Revistas e Burletas do Teatro São José: a menina-dos-olhos de Paschoal Segreto. Rio de Janeiro: Uni-Rio, centro de Letras e Artes. Programa de Pós-Graduação. Dissertação de Mestrado. 1997.

COSTA, Iná Camargo. “Dramaturgia Modernista em 22”. In: Literatura e Sociedade. № 7. São Paulo: USP/FFLCH/DTLLC, 2003/2004.

COUTINHO, Afrânio. A Literatura no Brasil. Vol. 5 e 6. São Paulo: Global, 2003. 
CRUZ, Heloisa de Faria (Org.). São Paulo em Revista: Catálogo de Publicações da Imprensa Cultural e de Variedades Paulistanas: 1870-1930. São Paulo: Arquivo do Estado, 1997.

. São Paulo em Papel e Tinta: Periodismo e Vida Urbana - 1890-1915.

São Paulo: EDUC, Fapesp, 2000.

DORIA, Gustavo. Moderno teatro brasileiro. Rio de Janeiro: SNT/MEC, 1975.

DOYLE, Plínio. História de Revistas e Jornais Literários. São Paulo: IEB/USP.

FARIA, João Roberto. “Álvaro Moreyra: Poesia e Teatro no Modernismo”. In: $O$ Teatro na Estante. São Paulo: Ateliê Editorial, 1998.

FERMINO, Ricardo Lísias Aidar. No Palco, no Papel e na Prisão: uma Biografia (seguida de antologia) de Álvaro Moreyra). Tese de Doutorado. São Paulo: FFLCH/USP, 2005.

FERRARESI, Carla Miucci. Papéis Normativos e Práticas Sociais: o Cinema e a Modernidade no Processo de Elaboração das Sociabilidades Paulistanas na São Paulo dos Anos de 1920. Tese de Doutorado. São Paulo: FFLCH/USP, 2007.

FERREIRA, Adriano de Assis. Teatro Trianon: forças da ordem X forças da desordem. Dissertação de Mestrado. São Paulo: FFLCH/USP, 2004.

FERREIRA, Procópio. Procópio Ferreira Apresenta Procópio: Um Depoimento para a História do Teatro no Brasil. Rio de Janeiro: Rocco, 2000.

GOMES, Tiago de Melo Gomes. Um Espelho no Palco: Identidades Sociais $e$ Massificação da Cultura no Teatro de Revista dos Anos 1920. Campinas: Ed. Unicamp, 2004.

GUELFI, Maria Lúcia Fernandes. Novíssima: Estética e Ideologia na Década de Vinte. São Paulo: IEB/USP, 1987.

GUINSBURG, J., FARIA, J. R. e LIMA, M. A. de. Dicionário do Teatro Brasileiro: Temas, Formas e Conceitos. São Paulo: Perspectiva, Sesc São Paulo, 2006.

HOLLANDA, Sérgio Buarque de. Entrevista. In: LEONEL, M. C. de M. Revista Estética. Dissertação de Mestrado. São Paulo: FFLCH/USP, 1976.

IGLEZIAS, Luiz. O Teatro da Minha Vida. Rio de Janeiro: Zelio Valverde, 1945.

IKEDA, Marilda A. Balieiro. Revista do Brasil - $2^{a}$ Fase - Contribuição para o Estudo do Modernismo Brasileiro. Dissertação de Mestrado. São Paulo: FFLCH/USP, 1975. 
JAMBEIRO, Othon et all. Tempos de Vargas: O Rádio e o Controle da Informação. Salvador: EDUFBA, 2004.

KREINZ, Glória Aparecida Rodrigues. Revista Nova - Contribuição para o Estudo do Modernismo Brasileiro. Dissertação de Mestrado. São Paulo: FFLCH/USP, 1979.

LAFETÁ, João Luiz. 1930: A Crítica e o Modernismo. São Paulo: Duas Cidades, Ed 34, 2000.

LARA, Cecília de. Klaxon e Terra Roxa e Outras Terras: dois periódicos modernistas de São Paulo. São Paulo: IEB, 1972.

"Antonio de Alcântara Machado e os Fundamentos do Teatro Brasileiro Moderno". In: O Percevejo. Ano IV, n. 05, 1997.

De Pirandello a Piolim: Alcântara Machado e o Teatro no Modernismo.

Rio de Janeiro: INACEN, 1987.

LEITE, Miriam Lifchitz Moreira. "O Periódico: Variedade e Transformação". Anais do Museu Paulista.Tomo XXVIII, São Paulo: Universidade de São Paulo, 1977/1978.

LEONEL, Maria Cecília de Moraes. Revista Estética. Dissertação de Mestrado. São Paulo: FFLCH/USP, 1976.

LUCA, Tânia Regina de. A Revista do Brasil - Um Diagnóstico para a (N)ação. São Paulo: UNESP, 1999.

MACHADO, Antônio de Alcântara. “Abre-Alas”. Revista de Antropofagia. nº 01, 1928.

MADEIRA, Wagner Martins. Formas do Teatro de Comédia: A Obra de Oduvaldo Vianna. Tese de Doutorado. São Paulo: FFLCH/USP, 2003.

MAGALDI, Sábato. Panorama do Teatro Brasileiro. 4.ed. São Paulo: Global, 1999. . Depois do Espetáculo. São Paulo: Perspectiva, 2003. . Teatro da Ruptura: Oswald de Andrade. São Paulo: Global, 2004.

MAGALDI, Sábato e VARGAS, Maria Theresa. Cem Anos de Teatro em São Paulo (18751974). São Paulo: Senac, 2000.

MAGALHÃES JR, Raimundo. As Mil e Uma Vidas de Leopoldo Froes. Rio de Janeiro: Civilização Brasileira, 1966.

MAGNO, Paschoal Carlos. "Teatro de Estudante". Dionysos. Rio de Janeiro: SNT, n. 23, 1978. 
MARTINS, Ana Luisa. Revistas em Revistas: Imprensa e Práticas Culturais em Tempos de República (1890-1922). São Paulo: Editora da USP: FAPESP: Imprensa Oficial do Estado, 2001.

MATERNO, Ângela. "A Crítica Teatral de Alcântara Machado". O Percevejo. Ano II, n. 02, 1994.

MICELI, Sérgio. Intelectuais e a Classe Dirigente no Brasil (1920-1945). São Paulo/Rio de Janeiro: Difel, 1979.

MICHALSKI, Yan e TROTTA, Rosyane. Teatro e Estado: As Companhias Oficiais de Teatro no Brasil: História e Polêmica. São Paulo/Rio de Janeiro: Hucitec, 1992.

MIGNON, Paul-Louis. Jacques Copeau ou le Mythe du Vieux-Colombier. Paris: Julliard, 1993.

MIRA, Maria Celeste. O Leitor e a Banca de Revistas. São Paulo: Olho d'Água/ Fapesp, 2001.

MORAES, Rubens Borba de. "Recordações de um Sobrevivente da Semana de Arte Moderna". In: AMARAL, Aracy A. Artes Plásticas na Semana de 22. $5^{a}$ ed. São Paulo: Editora 34, 1998.

MOREYRA, Álvaro. As Amargas, Não... Lembranças. Porto Alegre: Instituto Estadual do Livro, 1989.

NAPOLI, Roselis Oliveira de. Lanterna Verde e o Modernismo. São Paulo: IEB/USP, 1970.

NUNES, Mário. 40 Anos de Teatro. Rio de Janeiro: SNT, 1956, 4v.

OGAWA, Felícia Megumi. O Teatro Brasileiro dos Anos 30: Um Estudo Sociológico. Dissertação de Mestrado. São Paulo: FFLCH/USP, 1972.

OITICICA, Sonia. “Teatro de Estudante”. In: Dionysos. Rio de Janeiro: SNT, n. 23, 1978.

ORLOV, Martha Lívia Volpe. Revista do Brasil. Dissertação de Mestrado. São Paulo: FFLCH/USP, 1980.

OSCAR, Henrique. O Teatro e a Semana de Arte Moderna de São Paulo. Rio de Janeiro, 1985.

PAIVA, Savyano Cavalcante de. Viva o Rebolado! Vida e Morte do Teatro Brasileiro de Revista. Rio de Janeiro: Nova Fronteira, 1991. 
PERDIGÃO, Paulo. No Ar: PRK-30! O Mais Famoso Programa de Humor da Era do Rádio. 2ed. Rio de Janeiro: Casa da Palavra, 2003.

PEREIRA, Victor Hugo Adler. A Musa Carrancuda: Teatro e Poder no Estado Novo. Rio de Janeiro: Fundação Getúlio Vargas, 1998.

. "Os Intelectuais, o Mercado e o Estado na Modernização do Teatro Brasileiro". In: BOMENY, Helena (org). Constelação Capanema: Intelectuais e Políticas. Rio de Janeiro: Fundação Getúlio Vargas, 2001.

POLÔNIO, Sandro. "Teatro de Estudante". Dionysos. Rio de Janeiro: SNT, n. 23, 1978.

PRADO, Décio de Almeida. Peças, Pessoas e Personagens: o Teatro Brasileiro de Procópio Ferreira a Cacilda Becker. São Paulo: Companhia das Letras, 1993. . Seres, Coisas e Lugares: do Teatro ao Futebol. São Paulo: Companhia das Letras, 1997. . História Concisa do Teatro Brasileiro. São Paulo: Edusp, 1999. . Apresentação do Teatro Brasileiro Moderno: 1947-1955. São Paulo: Perspectiva, 2001. "O Teatro". In: ÁVILA, Affonso. O Modernismo. 2 ed. São Paulo: Perspectiva, 2002. . Teatro em Progresso: 1955-1964. São Paulo: Perspectiva, 2002. . O Teatro Brasileiro Moderno. 2.ed. São Paulo: Perspectiva, 2003.

QUEIROZ, Eliana. A Scena Muda como Fonte para a História do Cinema Brasileiro (1921-1933). Dissertação de Mestrado. São Paulo: ECA/USP, 1981.

RAMOS, Luiz Fernando. "Da Pateada à Apatia: O Teatro da Bagunça de Alcântara Machado e a Crítica de Teatro no Brasil”. O Percevejo, Ano II, n. 02, 1994.

REIS, Ângela de Castro. Cinira Polônio: a Divette Carioca: Estudo da Imagem Pública e do Trabalho de uma Atriz no Teatro Brasileiro da Virada do Século XIX. Rio de Janeiro: Arquivo Nacional, 1999.

RICARDO, Cassiano. Viagem no Tempo e no Espaço. Rio de Janeiro: José Olympio, 1970. RODRIGUES, Nelson. “Os Comediantes”. Dionysos. Rio de Janeiro: SNT, n. 22, 1975. ROMANELli, Kátia Bueno. A Revista Verde - Contribuição para o Estudo do Modernismo Brasileiro. Dissertação de Mestrado. São Paulo: FFLCH/USP, 1981. 
ROQUETTE-PINTO, E. “A Evolução do Cinema”. Revista do Brasil. Rio de Janeiro: Julho/1938.

RUIZ, Roberto. Teatro de Revista no Brasil: do Início à I Guerra Mundial. Rio de Janeiro: INACEN, 1988.

SANTA ROSA, Tomás. "Para um Teatro Teatral”. In: BARSANTE, Cássio Emmanuel. Santa Rosa em Cena. Rio de Janeiro: Instituto Nacional de Artes Cênicas, 1982.

SAROLDI, Luiz Carlos e MOREIRA, Sonia Virgínia. Rádio Nacional: o Brasil em Sintonia. 3 ed. Rio de Janeiro: Jorge Zahar Editor, 2005.

SILVA, Daniel Marques da. "Precisa arte e Engenho até": um Estudo sobre a Composição do Personagem-tipo através das Burletas de Luís Peixoto. Rio de Janeiro: Uni-Rio, Centro de Letras e Artes, Programa de Pós-Graduação. Dissertação de Mestrado. 1998.

SILVA, Flávio Luis Porto e. Rádio em Revista: Os Caminhos do Teatro de Revista no Rádio das Décadas de 20 e 30. Dissertação de Mestrado. São Paulo: USP, 2005.

SILVA, Margaret Abdulmassih Wood da. A Revista - Contribuição para o Estudo do Modernismo em Minas Gerais. Dissertação de Mestrado. São Paulo: FFLCH/USP, 1984.

SODRÉ, Nelson Werneck. História da Imprensa no Brasil. 4 ed. Rio de Janeiro: Mauad, 1999.

SOUSA, J. Galante. O Teatro no Brasil. Tomo I, Rio de Janeiro: Instituto Nacional do Livro, 1960.

VELlOSO, Mônica Pimenta. “Cultura e Poder Político”. In: OLIVEIRA, Lúcia Lippi et alli. Estado Novo: Ideologia e Poder. Rio de Janeiro: Zahar Editores, 1982.

VENEZIANO, Neyde. O Teatro de Revista no Brasil: Dramaturgia e Convenções. Campinas: Editora da Unicamp, 1991. . Não Adianta Chorar - Teatro de Revista Brasileiro... Oba! Campinas: Ed. Unicamp, 1996.

VIANNA, Renato. Sexo e Deus. Obras Completas - 2 vol. Rio de Janeiro: A Noite, 1957. VIOTTI, Sérgio. Dulcina e o Teatro do seu Tempo. Rio de Janeiro: Lacerda, 2000. 
Estatística da Imprensa Periódica no Brasil (1929-1930). Rio de Janeiro: Departamento Nacional de Estatística, 1931.

Site da Fundação Biblioteca Nacional do Rio de Janeiro: www.bn.br. 